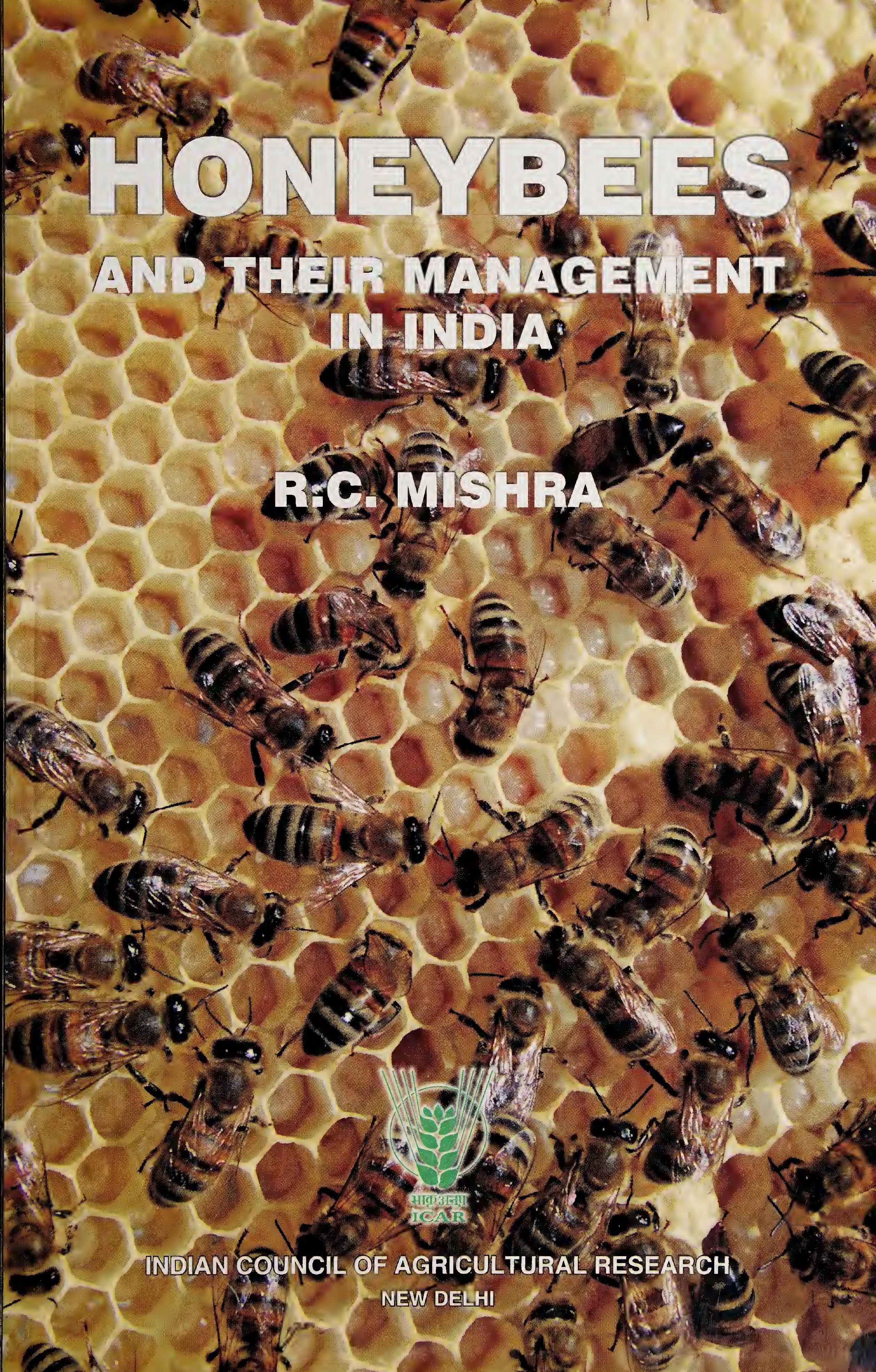


Digitized by the Internet Archive in 2018 


\title{
HONEYBEES AND THEIR MANAGEMENT IN INDIA
}

\author{
R.C. Mishra
}

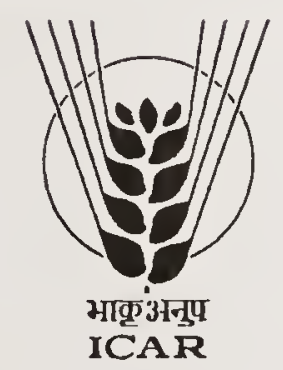

PUBLISHED BY

DIRECTORATE OF KNOWLEDGE MANAGEMENT IN AGRICULTURE INDIAN COUNCIL OF AGRICULTURAL RESEARCH KRISHI ANUSANDHAN BHAVAN, PUSA

NEW DELHI 110012 


\title{
FIRST PRINTED : MARCH 1995 \\ REPRINTED： : SEPTEMBER 2013
}

\author{
Project Director (DKMA) : Dr Rameshwar Singh \\ Incharge (English Editorial) : Dr Aruna T Kumar \\ Chief Production Officer : Dr V K Bharti
}

Senior Technical Officer (Production) : Punit Bhasin

(C) 1995, 2013, All Rights Reserved

Indian Council of Agricultural Research

New Delhi

ISBN : 978-81-7164-147-5

Price: ₹200

Published by Dr Rameshwar Singh, Project Director (DKMA), Directorate of Knowledge Management in Agriculture, Indian Council of Agricultural Research. Krishi Anusandhan Bhavan, Pusa, New Delhi 110012 and printed at M/s Chandu Press, D-97, Shakarpur, Delhi 110092. 


\section{FOREWORD}

A wide array of people are attracted to the fascinating world of honeybees, especially because they provide honey and also on account of their interesting ways of life. Somehow, research on honeybees in tropical and sub-tropical regions, including India, did not receive much attention in the past. It is only recently that the Indian Council of Agricultural Research has taken up the task of organized and systematic research in apiculture.

The beekeeping practices for domesticated Indian honeybee, Apis cerana indica $\mathrm{F}$. were adopted from the west with suitable modifications suiting to Indian honeybee. There is need to undertake intensive research for the refinement of management practices for improved honey yield and efficient pollination of crops. Production of other valuable hive products like royal jelly, beeswax and bee venom needs commercialization. There is a great diversity in regional agroclimatic conditions and flora. Therefore, for taking up beekeeping, there is a need to carry out some careful studies to explore the potential of each area.

In the process of controlling pests through the use of chemicals, the wild insect pollinators are under threat of being wiped out and, thus, the honeybees are equally endangered. Thus, the peasants and farmers in India will be deprived of the additional food and income through pollination services by these insects. The situation is grave because in India there is lesser awareness than in technologically advanced countries of the need to protect these insects from pesticidal hazards.

Honeybee genetics and breeding has remained a neglected area of research. Well-organized and concerted efforts in the field are urgently required. At present, 7 species of genus Apis are known to exist and these species are known to have diverse races and strains. The artificial queen bee insemination technique could not be exploited to maintain the germplasm and also for the improvement of stock.

Apis mellifera L. was introduced from abroad and established in India in sixties and has revolutionized the commercial beekeeping in the north-western states. The extension of the species to other potential states of the country has somehow been delayed. The sweet revolution should be attempted through popularization of Apis mellifera for commercial beekeeping, since the species is far superior in performance to Apis cerana indica.

The Indian Council of Agricultural Research is engaged in research and development activities in various disciplines of agriculture including apiculture. The book Beekeeping in India by Dr Sardar Singh.was published in 1962. This book served as a practical treatise for popularizing modern beekeeping in India. Since the publication of the book, a wealth of knowledge has been generated both in India and other countries. Therefore, the need arose to bring out a book with up-to-date information. I appreciate the efforts made by Dr R.C. Mishra in writing the book Honeybees and their Management in 
India. This is an attempt to present a world-wide picture of beekeeping, suitable for practical and class-room reference. The book is mainly focussed on Indian literature, though the contents also draw from the knowledge accumulated in more advanced countries. It is a comprehensive account on different aspects of beekeeping, and students, teachers and scientists will profit by studying it. I am sure, the book will generate awareness and catalyse action towards a more effective exploitation of honeybees for honey and other bee products as also for crop production through bee pollination.

New Delhi

28 December 1990
R.S. PARODA

Deputy Director-General (CS) Indian Council of Agricultural Research 


\section{INTRODUCTION}

Br:ckereping has been practised in India from a very long time by indigenous methods and this unscientific beekeeping is still in vogue in certain tribal arcas of the country. But now generally scientific beekeeping is done. After the introduction and popularization of movable frame hives the knowledge on management practices was borrowed from the West by adopting modifications suiting to Indian conditions.

Success in beckeeping mainly depends on the sound knowledge of biology, behaviour and diseases of bees and accordingly the management practices. The knowledge on biometry, developmental biology, morphology, anatomy, physiology and biochemistry and other behavioural patterns of bees in India is very fragmentary. It is imperative to standardize equipments for different bee species and their races under different regional variations. This should be an important field to draw the attention of apiculture workers. Apis mellifera was introduced and established in India in the sixties and has proved very useful for commercial beekeeping in north-western states of the country. There is a need to quickly evaluate its usefulness in comparison to Indian hive-bee in all the potential bcekeeping areas and extend the species, if proved superior.

Different regions of the country have diverse climatic and floristic conditions. It is believed that only less than $50 \%$ of the present day flora is availed by the bees and the rest goes waste. In the past, many wild insect pollinators were available and they served the purpose of pollination of crops. But during recent years the wild insect pollinators' population is fast declining due to the changed agricultural practices. This has led to insufficient pollination of crops and has warranted the inclusion of planned bee pollination as an agricultural input to optimize the crop yields. There are still many crops, especially in context to Indian conditions, for which the pollination ecology and pollination requirements are necessary to be worked out.

Bee diseases and bee enemies problems in India are different from other countries. In the West there is only one Apis species but in India we have three indigenous species and one, now established, introduced from the West. We are therefore likely to encounter larger number of diseases and enemies and so Indian scientists shall have to be more alert in gathering enough information to fight the maladies and make beekeeping a profitable venture.

Bee products have marty uses in food, medicine, pharmaceutical and cosmetic industry. Though, some research has been carried out on Indian honeys and beeswax but bee venom, royal jelly, pollen and propolis are still neglected. Therefore, systematic work on all aspects of bee-product technology is essential.

Many developments in bee research have taken place at the world scene and some knowledge has also been accumulated with reference to Indian 
conditions. Attempt has been made to present the information to the bcekecping fraternity in the book Honeybees and their Management in India. Different topics have been discussed on the basis of available literature and relevant Indian works have been cited so as to give specific idea about the position in India. 


\section{CONTENTS}

Page

FOREWORD

INTRODUCTION

1. IMPORTANCE AND HISTORY

Importance

Past and present

2. BEES AND THEIR ECONOMIC IMPORTANCE

Wild bees

Species of honeybees

3. MORPHOLOGY, ANATOMY, COLONY

ORGANIZATION AND LIFE CYCLE

Morphology

Anatomy

Colony organization

Development

Points of caste distinction

4. BEEKEEPING EQUIPMENTS

Langstroth ten-frame hive

Newton hive

Other beekeeping equipments

Equipments for handling bees

5. SOCIAL BEHAVIOUR OF BEES AND RELATED

MANAGEMENT PRACTICES

Division of labour

Food gathering and artificial feeding

Communication

Working habits of field bees

6. INSTINCT OF REPRODUCTION AND

RELATED MANAGEMENT

Control of reproduction

Queen and its management

Laying workers

Reproduction of species-swarming, prevention and control

Making colony increase

7. QUEEN REARING AND ARTIFICIAL QUEEN

BEE INSEMINATION

Selection of mother stock

Biological basis of queen rearing

Methods of queen rearing

Artificial mating 
8. BEE PASTURAGE

Nectar-sugar concentration

Nectar composition

Factors affecting nectar secretion

Bee flora of India

9. SEASONAL MANAGEMENT

Spring management

Honey flow period

Honey extraction

Summer routine

Monsoon problems

Autumn management

Winter management

Winter hive packing

10. DISEASES OF BEES AND THEIR ENEMIES

Viral diseases

Bacterial diseases

Protozoan disease

Fungal diseases

Mites

Insect enemies of bees

Birds and other enemies

11. BEEHIVE PRODUCTS

Honey

Wax

Bee venom

Propolis

Royal jelly

12. POLLINATION

Pollination and fertilization

External agents of pollen transfer

Insect pollinators

True honeybees

Pollination of crops

13. PESTICIDAL POISONING TO HONEYBEES

How are bees exposed to pesticidal hazards

Symptoms and effects of pesticidal poisoning

Pesticides and their relative toxicity to bees

Reduce pesticidal poisoning to bees

Bee repellents

Care of the poisoned colonies

Plant poisoning to bees 


\section{IMPORTANCE AND HISTORY}

\section{Importance}

The honeybee and the fruits of its toils have been familiar to man since pre-historic times. It is one of the few insects that are directly beneficial to man. One comes across a number of folk-lores praising the honeybee's diligence, usefulness and sacrifice. These winged creatures and the honey they produce find mention in many religious epics. Figures and carvings of the honeybee, its combs and hives are found in tombs, coffins, crowns, maces of kings and coins of ancient and modern empires. Many religions speak high of honey and beeswax and enjoin their followers to use these two commodities in various rites performed during festivals and on many occasions in the life of an individual. Honey is also prized as food and medicine and the uses of beeswax are many and varied.

A honeybee colony has a fascination of its own and naturalists, poets and thinkers alike have revelled in the pleasant art of solving its mysteries. It will not be wrong to say that the honeybee is one of the most studied creature and numerous books have been written about it. Some writers have admired honeybees for their industriousness, unity, self-sacrifice, toleration, division of labour and spirit of social service. Others believe that by working with them, one acquires bappiness, develops a philosophy of self sufficiency, selfreliance, self-preservation, and learns co-ordination of thoughts. The economic-

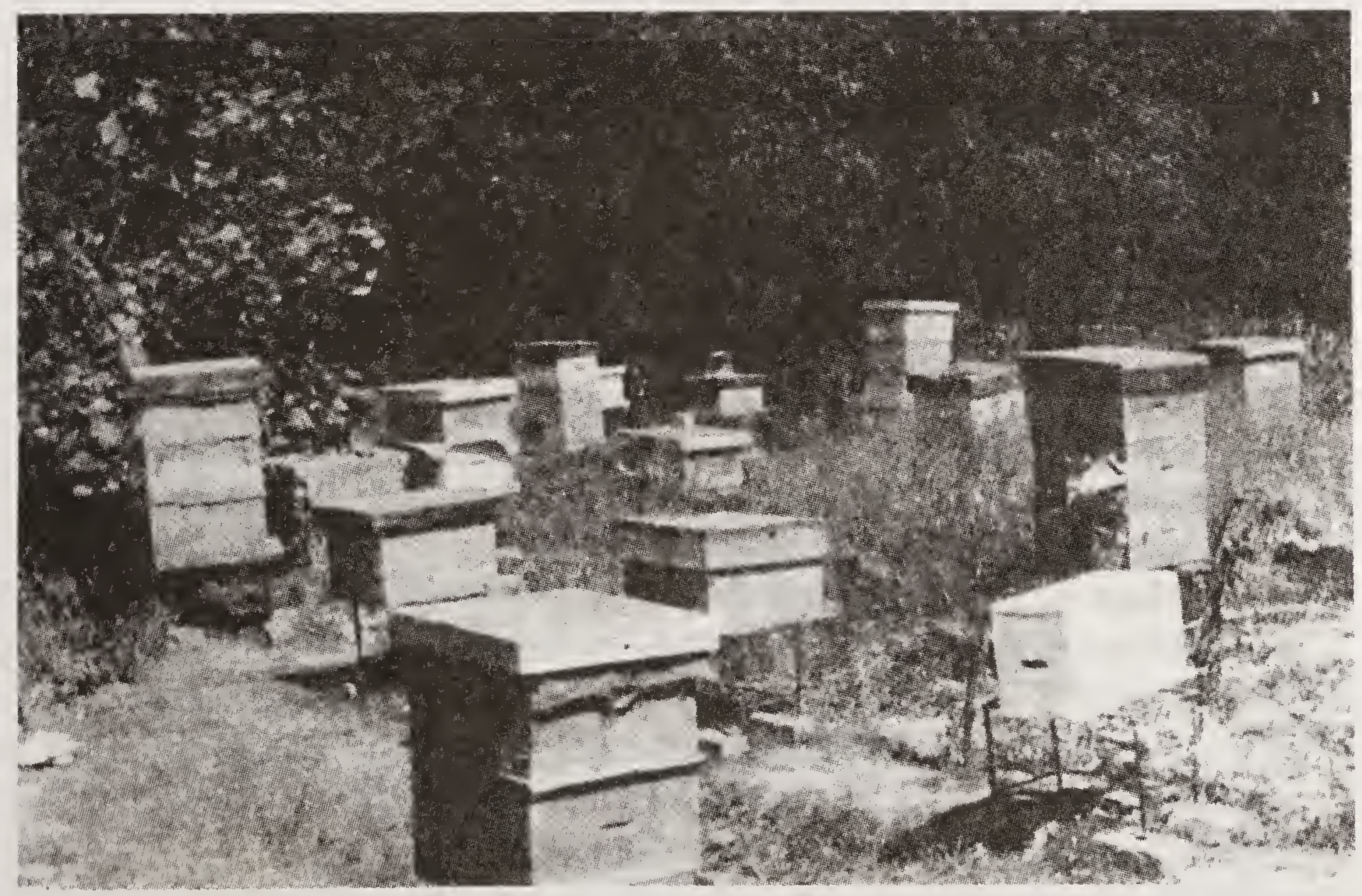

Fig. 1. A small apiary in movable frame hives. 
minded people keep them for honey and wax. The bee-sting has a quality of healing muscular and nervous pains, aches of sciatica, rheumatism and arthritis, reduces cholestrol level and relieves of heart troubles.

Beekeeping is an ideal, absorbing, instructive and economically profitable bobby. A few bee colonies can be maintained in the backyard of the house and the honey thus produced will add to the quality of diet of the family. This can also be a useful side-line business if a farmer keeps some bee colonies and produces honey and wax as it will add to his income and will improve his economic condition. There is enough scope of taking up beekeeping on a commercial scale. Decision on taking up beekeeping as cottage industry or on commerical scale does necessarily depend upon the potentials and the resources of the area. Taking up beekeeping at any scale is advantageous because: (i) It requires light physical work and various operations can easily be done even by children and women. (ii) Bee colonies do not require constant care and even disguised labour can be utilized. Besides man power and labour, the beekeeping also does not compete with any other branch of agriculture for resources. (iii) Beekeeping requires very little financial investment. (iv) Beekeeping has a special advantage in India where majority of people are small or marginal land holders or even landless. Beekeeping does not require land because the colonies can be kept in the wasteland, forests and edges of fields. (v) Beekeeping requires some equipments and it encourages the local artisans.

Beekeeping is useful not only to the beekeeper who receives income from the honey and beeswax but it also benefits the community as a whole. The bees forage for nectar and pollen in the vicinity and during food collection they bring about pollination of cultivated crops. Cross-pollination by bees not only helps in increasing quality and quantity of yields in cross-pollinated crops but also benefits even many self pollinated crops. The trait of honeybees to visit and pollinate blossoms has been explored for pollinating orchard, vegetable, oilseed and other crops for increasing yield.

\section{Past and present}

In ancient times honeybees used to be kept in a crude manner in India as in other countries of the world. However, after the improvement in the methods of beekeeping in the West during the second half of the nineteenth century, with the discovery of the principle of bee space (L.L. Langstroth, 1951) and subsequent refinements in the methods of bee management, efforts were made to adopt these innovations in India also. Such attempts have a long and chequered history, the salient features of which a re outlined here.

First attempt to keep bees in movable frame-hives were made in 1882 in Bengal and in 1883-84 in Punjab but with little success. In 1883; Government of India published the information on beekeeping, collected from the provinces, under the title $A$ Collection of Papers on Beekeeping in India. An year later John Douglas, an employee of the Telegraph Department, published $A$ Handbook of Beekeeping in India. This book was based on his experiences in keeping the Indian honeybee in modern hives. Later, in 1907, the work 
was taken up by the then Imperial Entomologist at Pusa and it continued up to 1919. Besides a few papers, a bulletin entitled Beekeeping by C.C. Ghosh was also published which provided useful information on the subject. At the same time in Punjab Sir Louis Dane aroused interest in beekeeping. F.S. Cousins was employed as apiarist and the Punjab Beekeepers' Association with headquarters in Shimla was formed. A Guide for Beekeeping was published in 1916. In south India, Rev. Newton trained several beekeepers during 1911-17 and devised a Newton's hive (named after him) which is still common there. Travancore state took up beekeeping work in 1917 and Mysore in 1925.

The recommendation of the Royal Commission on Agriculture (1928) for developing cottage industries gave a fillip to beekeeping. Work on this subject in right earnest was taken up in Madras in 1931, Punjab in 1933, Coorg in 1934 and U.P. in 1938. Other states and provinces followed suit but no important landmark was made. Beekeepers of India organized themselves into an All India Beekeepers' Association during 1938-39. Since then the Association is publishing the Indian Bee Journal. The Indian Council of Agricultural Research co-ordinates the activities of reasearch workers in beekeeping. The Council established a Beekeeping Research Station in the Punjab in 1945 and six years later at Coimbatore in Tamil Nadu. From 1950, the ICAR has been funding various research projects on honeybees in the universities and other organizations. In addition to that from 1980, it has started an All India Co-ordinated Project on Honeybees Research and Training. During the past three decades State Universities, and Village and Khadi Industries Commission a re also contributing to the development of beekeeping.

Apis species were present in old world countries since ages but to new world countries the honeybees were introduced only 100-400 years ago. There are four Apis species viz. Rock bee Apis dorsata $\mathrm{F}$., the little honeybee Apis florea F., Indian honeybee Apis cerana indica F. and European honeybee Apis mellifera L. Former two species are wild and latter two are domesticated for commercial beekeeping. First three species were present in India but Apis mellifera was introduced from European countries. Before sixties many unsuccessful attempts were made by the workers to introduce and establish mellifera bees. First attempt, as per record, is of Ghosh (1920), who imported three colonies from Italy and maintained a small apiary up to 1931. Failure of queen mating because of various reasons led to loss of colonies. Thompson (1940) has also mentioned about some unsuccessful attempts in various parts of India to introduce mellifera bees.. He reported that Baldry introduced $A$. mellifera in Mababaleshwar (M.S.) and maintained the apiary for six years; the colonies were later shifted to Coimbatore which soon dwindled and perished. Bees brought to Kerala by Thompson, in thirties, could not be established. He attributed it to unfavourable climatic conditions of the area to mellifera bees. Beadnell (1939) brought many consigniments of $A$. mellifera and maintained an apiary in Nilgiri Hills. Rehman and Singh $(1940,1945)$ received two consignments of two and three colonies. Attempts to interbreed failed and $A$. cerana indica and $A$. mellifera even did not accept each others 
brood, workers or queens. A. mellifera colonies were imported into Kashmir in 1951 (Vats, 1953). The queens were introduced to A. cerana indica colonies and were reported to be doing well until 1959. After that there is no report on the progress of these bees, and it is presumed that they have perished. Successful introduction and establishment of $A$. mellifera could become possible in the sixties. A. mellifer $a$ and its hybrids were obtained from U.S.A. and Italy between 1962-1964 and were introduced in Nagrota, Himachal Pradesh (Atwal and Sharma, 1967, 1970a, 1970b; Atwal and Goyal, 1973). The queens were successfully introduced in $A$. cerana indica nuclei with young workers. Performance of five strains of $A$. mellifera was studied (Atwal and Sharma, 1970b); 'Californian yellow' and 'Starline' strains were superior to others in colony strength, brood rearing and food storage capacity. The 'Italian' strain was similar to 'californian' strain in general behaviour and brood rearing activity but was poorer in honey production. In all the strains, honey production was much better than that of $A$. cerana indica.

The exotic bee species is now being used for commercial bee keeping in north western states of the country. Earlier attempts to establish the species have probably failed due to lack of knowledge rather than the unsuitability of the area for the species.

From the later part of twentieth century some organizations have been involved in beekeeping research and development and their efforts have resulted into standardization of management practices. Most management practices for hive-bees in India were adopted from Europe/U.SiA. suiting to the Indian conditions and the climate. Despite the above mentioned efforts, the growth of beekeeping in India is not encouraging and the number of hivebee colonies as also the honey production remains miserably low. Even at present the number of bee clonies in India is about one million.

Table 1. Growth of beekeeping in India*

\begin{tabular}{lccc}
\hline Year & $\begin{array}{c}\text { No.of clonies } \\
\text { (in thousands) }\end{array}$ & $\begin{array}{c}\text { Honey production } \\
\text { (metric tonnes) }\end{array}$ & $\begin{array}{c}\text { Beeswax production } \\
\text { (metric tonnes) }\end{array}$ \\
\hline $1955-56$ & 15.57 & 21.00 & - \\
$1965-66$ & 237.54 & $1,140.16$ & - \\
$1972-73$ & 523.56 & $2,883.99$ & 15.45 \\
$1977-78$ & 635.98 & $3,497.07$ & 23.17 \\
$1980-81$ & 717.58 & $5,030.62$ & 11.71 \\
$1982-83$ & 807.06 & $5,723.53$ & 18.71 \\
$1984-85$ & 868.81 & $5,507.36$ & 19.51 \\
$1985-86$ & 929.70 & $6,182.15$ & 29.10 \\
\hline
\end{tabular}

* Annual Statistical Reports of KVIC.

Most serious problem for Indian beekeeping has been the decreasing honey plants during the past few decades but during recent years national and state governments and local organizations have helped to expand the planted area of bee forages and thus stopped the reduction of bee flora. It has improved the prospects of apiculture. It is estimated that less than half of the present day flora is being availed by bees. Besides the flora, the strategies for 
beekeeping development have to be reoriented to achieve fast progress. Beekeeping with Indian honeybees was virtually unknown in the states of Punjab and Haryana. Beekeeping with Apis mellifera was taken up in Punjab by the beekeepers in 1977. The industry grew very fast and in 1987 there were $68,(100$ colonies giving 620 tonnes of honey. The beekeeping has also received boost in Himachal Pradesh, Jammu and Kashmir and Haryana where Apis mellifera is now used in commercial beekeeping. The present status of beekeeping in different states of India is given in Table 2.

Table 2. Status of beekeeping in different states of India (1985-86)*

\begin{tabular}{lrc}
\hline States & $\begin{array}{c}\text { Honey production } \\
\text { (metric tonnes) }\end{array}$ & $\begin{array}{c}\text { Beeswax production } \\
\text { (netric tonnes) }\end{array}$ \\
\hline Andhra Pradesh & 126.69 & 0.96 \\
Assan & 296.67 & 0.21 \\
Bihar & 334.37 & 0.61 \\
Ciujarat & 0.18 & - \\
Haryana & 8.10 & 0.10 \\
Himachal Pradesh & 30.50 & 2.81 \\
Jannuu and Kashmir & 36.53 & 1.07 \\
Karnataka & 660.29 & 7.55 \\
Kerala & 2177.53 & 9.63 \\
Madhya Pradesh & 25.74 & 0.19 \\
Maharashtra & 46.44 & 0.03 \\
Manipur & 99.24 & 0.25 \\
Meghalaya & 43.89 & 0.22 \\
Nagaland & 11.37 & - \\
Orissa & 393.42 & 0.19 \\
Punjab & 84.82 & 0.85 \\
Rajasthan & 0.06 & - \\
Sikkim & 5.04 & - \\
Tanil Nadu & 1343.47 & 4.34 \\
Tripura & 27.20 & - \\
Uttar Pradesh & 12.39 & 0.01 \\
West Bengal & 379.56 & 0.05 \\
Arunachal Pradesh & 0.43 & - \\
Delhi & 0.29 & - \\
Pondicherry & 1.76 & - \\
Goa. Dänan and Diu & 0.17 & - \\
\hline
\end{tabular}

* Annual Report of the KVIC 1985-86.

\section{REFERENCES}

Atwal, A.S. and Groyal, N.P. 1973. Introduction of Apis mellifera in Punjab plains. Indian Bee J. 35 $(1-4): 1-9$.

Atwal, A.S. and Sharma, O.P. 1967. The introduction of Apis mellifera queens into Apis indica colonies and the associated behaviour of the two species. XXI Int. Beekeep. Congr. Prelim. Sci Meet Summ. Paper 70, p 77.

Atwal, A.S. and Sharma, O.P. 1970a. Brood rearing activity of the Italian honeybee, Apis mellifera L. in Punjab plains at Ludhiana. Indian Bee J. 32 : 62-67.

Atwal, A.S. and Sharma, O.P. 1970b. Studies on the performance of five strains of Apis mellifera L. as compared with Apis indica F. under Nagrota conditions. J. Res. Ludhin !? 7 (4) : 477-86. 
Beadnell, C.B. 1959. Transporting bees abroad. Brit. Bee J. 67 : 190.

Ghosh, C.C. 1920. Beekeeping in India. Proc. III Ent. Meeting, Pusa 2 : 770-82.

Rehman, K.A. and Singh, S. 1940. Italian versus Indian bees. Indian Bee J. 2 : 1-2.

Rehman, K.A. and Singh, S. 1945. American bees by air. Indian Bee J. 7 : 5-6.

Thompson, C.R. 1940. Presidential address to First Annual General Meeting of the All India Beekeepers Association. Indian Bee J. 2 (1/2) : 10-13.

Thompson, C.R. 1944. Research work on Apis mellifera introduced into India. Indian Bee J. 6 (11/ 12) : 163-64, 168.

Vats, B.R. 1953. Breeding Italian bees in Kashmir. Kashmir 3 (2) : 23-24,33. 


\section{BEES AND THEIR ECONOMIC IMPORTANCE}

BeEs belong to superfamily Apoidea of the order Hymenoptera. The superfamily includes about 250 genera in nine families. These bees are either solitary or lead a social life but all individuals share some common characteristics. Body of all the bees is covered with branched hairs. Nearly all bees feed on pollens and nectar and they tend the young ones in the cells with food for the developing individual. They make nests with wax secreted from their bodies, resins, mud, sand, pieces of leaves, hairs and fibres or from secretions of sting gland and silk produced by adults. Table 3 shows the phylogeny and relationships between the bees of India and the systematic. placement, given by Batra (1977).

\section{Wild bees}

There are large number of species of Apoidea and the wild bees are present wherever the plants grow. Bees belonging to this superfamily have branched, plumose, sparse to dense, long or short hairs on their body parts; they carry pollen in the tufts of hairs. They have long tongue for collecting nectar. Sting is the normal defence organ but stingless bees bite instead of stinging. Young ones are fed on nectar and pollen. Like true honeybees, the workers of wild bees also secrete royal jelly for feeding the larvae. Feeding may be through complete provisioning for whole of larval life and the egg is laid only after the cell is fully provisioned or it may be intermittant. There are also examples where workers lay nutritive eggs which are eaten by queens.

The wild bees can be solitary, gregarious or social. In case of solitary Apoidea the females build the cells, provision them, lay eggs in them and seal them. In some species the solitary individuals make nest close to each other and may be called gregarious species. Social bees like Apis spp., Bombus spp., live together in large numbers. Their colonies have the special feature of division of labour; the queen being only the egg laying individual.

Nesting babits of Apoidea vary widely; the nest cells are built with wax secreted by them, saliva, resins and waxes from plants, sand pebbles, cut leaves, plant fibres etc. They make nest in the holes, hollows or crevices in trees, rocks or walls and some even dig holes in pithy stems. Males neither help in nest building nor in defence and food collection.

Wild bees are important for agriculture and to our economy. They are efficient pollinators of our cultivated and wild fauna and render the valuable pollination service. Some knowledge has beell gathered to manipulate some species of the wild bees for pollination. Megachile spp. are the successful examples through which the management for pollination has been achieved. Nesting sites ean be provided and immature stages can be transferred there. 
Table 3. Bees of superfamily Apoidea

\begin{tabular}{|c|c|c|}
\hline Family & Sub-family & (icencra \\
\hline \multirow[t]{2}{*}{ Colletidae } & Colletinae & collentus \\
\hline & Hylacinae & Hylaeus \\
\hline \multirow[t]{6}{*}{ Halictidae } & Halictinae & Halictus: \\
\hline & & Lasioglosium \\
\hline & & Nomioides \\
\hline & & Sphecodes \\
\hline & Nomiinae & Nomia \\
\hline & Dufoureinae & Systropha \\
\hline Andrenidae & Andreninae & Andrena \\
\hline Melittidae & C.tenoplectrinae & Ctenoplectra \\
\hline \multirow[t]{10}{*}{ Megachilidae } & Megachilinae & Chalicodama \\
\hline & & Hariades \\
\hline & & Coelioxy's \\
\hline & & Auchocopa \\
\hline & & Osmia \\
\hline & Anthidinae & Authidium \\
\hline & & Anthidiellum \\
\hline & & Parevospis \\
\hline & & Stelis \\
\hline & Lithurginae & Lithuryus \\
\hline \multirow[t]{19}{*}{ Anthophoridae } & Anthophorinae & Paratiophites \\
\hline & & Tetralonia \\
\hline & 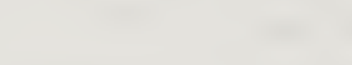 & Tetraloniella \\
\hline & & Anthopliora \\
\hline & & Protomelissa \\
\hline & & Amegilla \\
\hline & & Habropoda \\
\hline & & Elaphropoda \\
\hline & & Tyreus \\
\hline & & Melecta \\
\hline & Nomadinae & Nomada \\
\hline & & Ammobates \\
\hline & & Morgania \\
\hline & & Epeolus \\
\hline & Xylocopinae & $X y l o c o p a$ \\
\hline & & Proxylocopa \\
\hline & & Ceratina \\
\hline & , & Pithitis \\
\hline & & Braunsapis \\
\hline \multirow[t]{4}{*}{ Apidae } & Meliponinae & Trigona \\
\hline & Bombinae & Bombus \\
\hline & & Psithyrus \\
\hline & Apinae & Apis \\
\hline
\end{tabular}

Osmia spp. can be managed by providing bamboo pieces and bumble bees can nest in boxes. Melipona and Trigona bees can be induced to build nests in special boxes. Search for more species and their managenunt for pollination, especially of crops where true honeybees are not effective, should be pursued.

The family Apidae includes bumble bees, stingless bees and true honeybees. Bumble bees collect food for larvae and have social organization. Fecundated females come out of hibernation in the spring, make wax cells, provision them with pollen and nectar before depociting an egg. Full-grown larvae spin 
cocoon and newly emerged females, having underdeveloped gonads assist the mother female to expand the nest. In autumn both males and females are produced and females after mating go for winter hibernation. Bumble bees have thick insulating hairs and are very efficient in thermoregulation. These are found in Himalayas (Mani, 1962) $4000 \mathrm{~m}$ above sea-level.

The stingless bees are found in tropical parts of India. These bees are not truly stingless but the sting is poorly developed. They defend by biting. They make nests in the ground, in bollow of trees, bamboos, rocks, or cracks of walls. Nest cells are made of wax and plant resins. Trigona can be kept in hives (Fig.2). A colony consists of a queen, few hundred to few thousand workers and drones during colony breeding season. Honey and brood cells are separate in the nest. Bees have a language for communicating with the inmates of the nest.

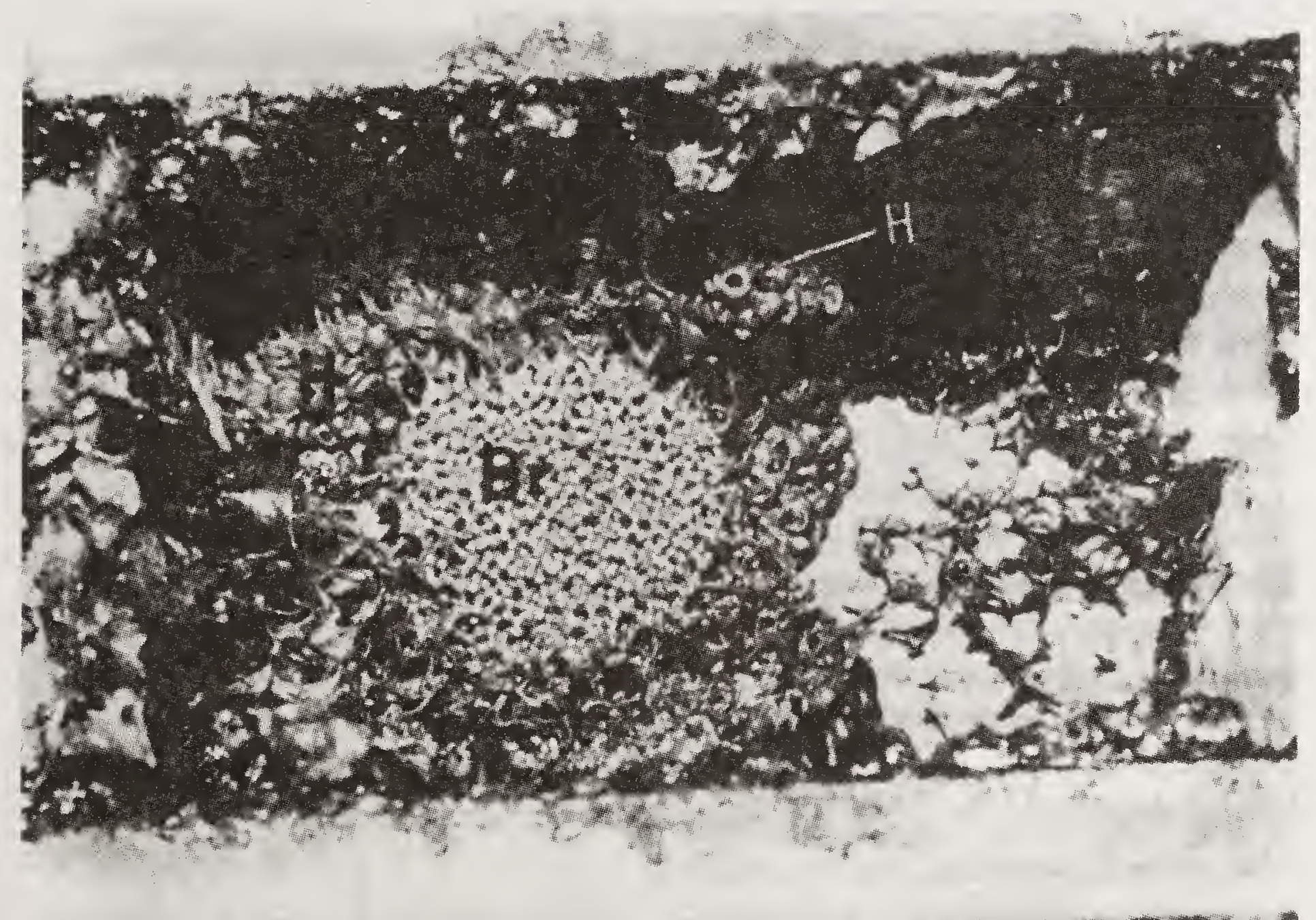

Fig. 2. Trigona colony kept in box; brood and honey cells in the nest are present.

\section{Species of honeybees}

True honeybees have adapted to varied climates. The origin of Apis is believed to be from near-east since many forms of Apis spp. are present between Mediterranean and Caucasus (Deodikar and Thakar, 1966).

Apis species were present in old world countries since ages but to new world countries the honeybees were introduced only 100 to 400 years ago. There are four Apis species viz. Rock bee, Apis dorsata; the little bee, Apis florea; Asian honeybee, Apis cerana and European honeybee, Apis mellifera. Apis cerana indica is the race of Apis cerana present in India. The former two species are wild and latter two are domesticated and serve the commercial beekeeping. First three species were present in India but Apis mellifera was introduced from European countries. 
Rock bee (Apis dorsata F.). It is met all over India in the plains and in the hilly areas up to $1600 \mathrm{~m}$ above sea-level. Geographical distribution extends to Pakistan, Sri Lanka, Malaysia, Indo-China region, Philippines, China and Indonesia. During summer the colonies migrate to mountains up to the elevation of about $2100 \mathrm{~m}$ to avoid extreme heat or in search of flora. The colonies arrive in hills in March and April and return to plains in June/ July before the monsoons. During migration the swarms are known to make short halts en route. During winters they are abundantly found in plains. The migration improves colony survival and provides several crops for honey in the areas on route during the year.

A. dorsata builds single-comb nest attached to a branch of tree, rocks and ceilings of neglected and uninbabitated houses etc. protecting it from direct sun rays and rain. Concentration of colonies on one tree is common and there can be 50 to 100 colonies on a tree where bee forage sources are plenty. Colonies return to the same tree year after year. Either some scent is left by the swarm at the nesting site or suitability of the site may be the reason for this phenomenon.

The comb area can be up to $1 \mathrm{~m}^{2}$. Worker and drone cells are equal in size. There are 4.50-4.75 cells per linear $25 \mathrm{~mm}$ with a mean depth of 16 $\mathrm{mm}$. Drone cells are differentiated by height alone (Thakar and Tonapi, 1961, 1962; Reddy, 1980b). About 7000 bees would weigh one kilogram. Average tongue length is $6.684 \mathrm{~mm}$. The queen is darker in colour than the workers, about $1 / 5$ long as the workers and about $2 \mathrm{~mm}$ broader.

Rock bee has a ferocious temperament and is provoked by slight disturbance. Worker bees attack en masse and follow the victim over long distances. Worker bees cover the comb like a curtain and orient upwards for insulation and protection. They are sensitive to smoke which is normally used by honey hunters.

This species is a good honey gatherer. Honey is stored in the top half portion of the comb. It can, therefore, be harvested without destroying the colony by cutting the honey storing portion of the comb. As high as 50 to $80 \mathrm{~kg}$ honey per colony can be obtained. A sizable portion of honey produced in India comes from $\dot{A}$. dorsata species. There appears to be some possibilities of semi-domestication of this wild species (Fig.3). Fletcher (1952) reported that attempts to keep $A$. dorsata in hives met with no success. Muttoo (1952), on the other hand, reported that rock bee swarms could be made to settle on two storey frames. These were fixed to strong branches of known bee tree just before the swarms were due to return. The frames with bees could be lowered to the ground with ropes and could be manipulated. Similar method of attracting $A$. dorsata colonies to wooden planks was given by Muthappa (1979) in which he used the juice of Cinnamomum incus as an attractant. In an experiment a few of $A$. dorsata larvae placed in queen cell cups reared by $A$. cerana indica workers and then queen cells were capped. However, no adult queens emerged. Introduction of mated queens (obtained from colonies) in nuclei of young workers of $A$. cerana indica or $A$. mellifera as a method to domesticate the wild bee, was attempted (Mishra et al., 1977) but the 


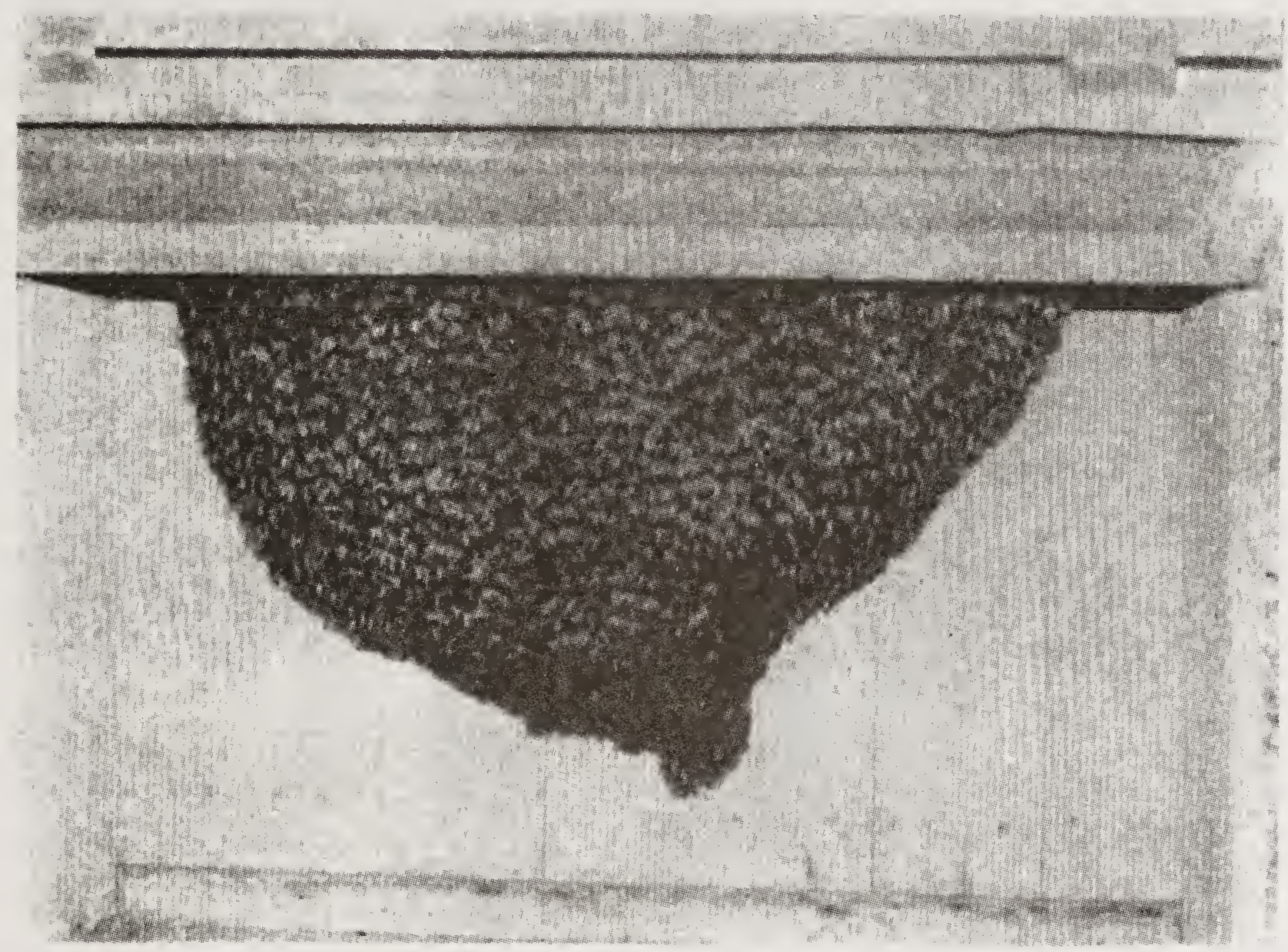

Fig. 3. Apis dorsata colony in specially designed hive, covered from three sides with front open. Colony can be maintained in semi-domesticated condition for few months.

queens were not accepted. Observations on the biology of the species, in general, show their behaviour to be similar to domesticated Apis species. The egg placement in the cells, the concentric arrangement of brood, the raising of queen cells, issue of swarms, communication by dances etc. are broadly simlar to $A$. mellifera and $A$. cerana indica. But in contrast to these $A$. dorsata bees have been reported to forage during night also. Concerted efforts in systematic way are needed to get more of the species. This species is very hard working and very efficient pollinator of crops in India.

Little bee (Apis florea Fab.). This species is found in plains of India up to about $300 \mathrm{~m}$ above sea-level. This is a wild bee but attempts to keep it in specially designed hives have met with partial success in India. Whitecombe (1982) has however described the successful method of keeping the colonies in hives in Oman. Apis florea is highly migratory but long distance migrations are unknown. Disturbances cause them to desert the comb, leaving behind honey, brood and pollen storess. But the bees continue to return to old comb to take away comb wax, honey and pollen. Mean tongue length of $A$. florea is $3.27 \mathrm{~mm}$. A comb has 13.2 cells per $\mathrm{cm}^{2}$ (Narayànan et al., 1960) and number of cells per linear $\mathrm{cm}$ is 3.50 (Mutto, 1957; Thakar and Tonapi, 1962).

The little bee builds a single comb nest and the comb is fixed to branches of bushes, hedges, trees, etc. (Fig. 4) in the shaded places. In the autumn they move short distances to unshaded nesting sites. The comb is broad at the top 


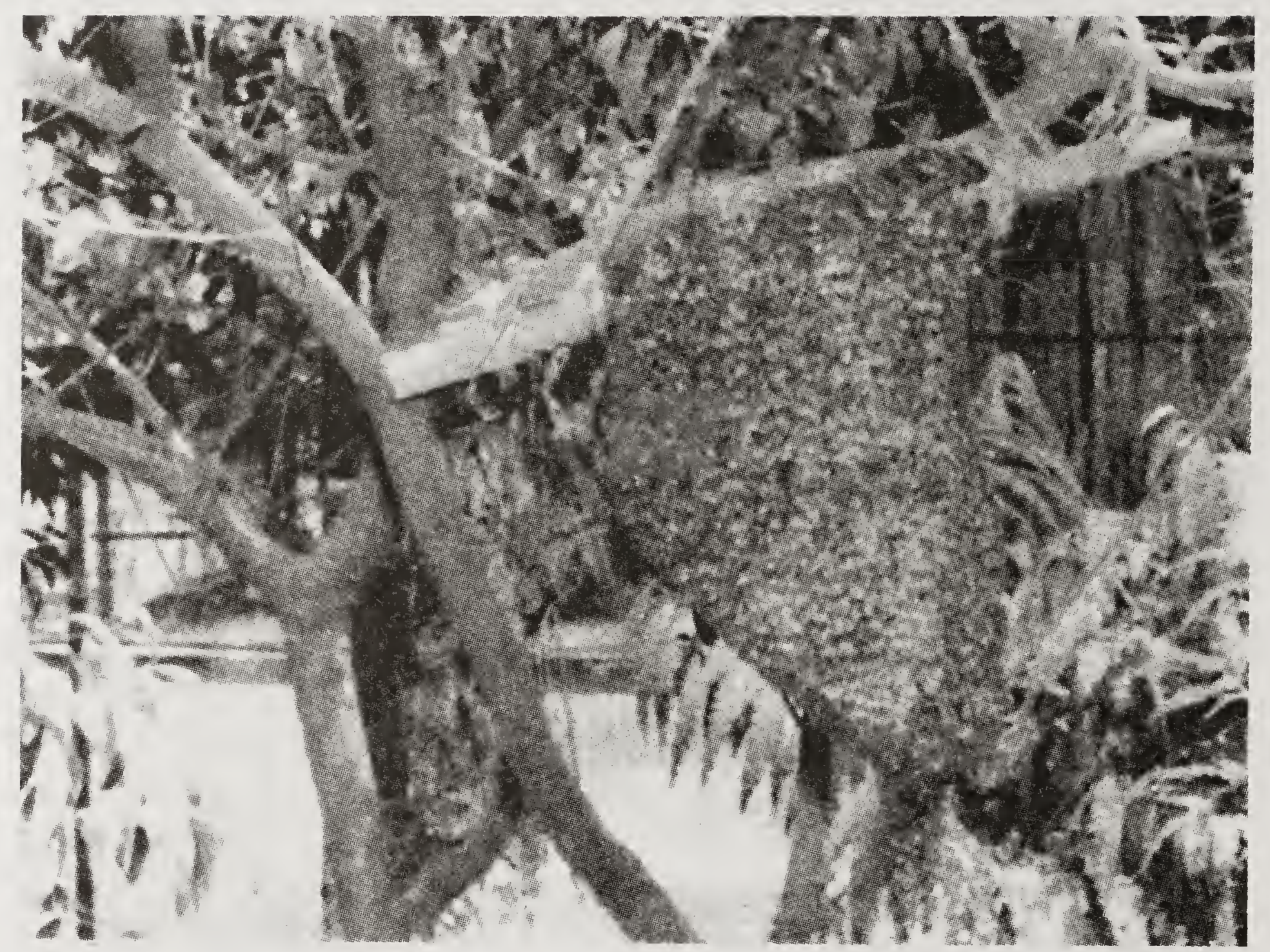

Fig. 4. Apis florea colony on a branch of a low tree.

and it serves as a landing place for the foragers. The comb is always covered by a curtain of bees. Drone cells are 1.55 times larger in diameter than worker cells. Queen cells are raised in spring and autumn at the bottom edge of the comb. These bees are very prone to swarming. They are gentle in temperament, however they do sting when irritatci. Colonies can be shifted to crops at blooming time for pollination.

This species is distributed in India, Sri Lanka, Pakistan, Indo-China region, Malaysia, Philippines, Indonesia and up to Iran and Oman in the west.

Apis florea is a poor honey yielder and a comb yields 200 to $900 \mathrm{~g}$ of honey. This honey is thin in consistency. Honey hunters take away the whole comb and thus destroy large number of colonies. The honey produced by this species is believed to have special medicinal qualities but there are no scientific studies to support this belief. The medicinal value, if any, must be attributted to the nectar of the plants in the locality which are available to other bee species also. A. florea honey fetches bigher price in countries like Oman.

Indian honeybee (Apis cerana indica Fab.). This species had been the base of Indian beekeeping and is found throughout India except the plains of north India. This species is also distributed in Pakistan, Sri Lanka, Malaysia, Indo-China, Philippines, China, USSR, Japan and Indonesia. It thrives up to $2500 \mathrm{~m}$ above sea level. In China and Japan the indigenous domesticated $A$. cerana has now mostly been replaced by $A$. mellifer $a$ which was introduced some years ago. In Japan Apis cerana is now present in small numbers in the 
hills. In other countries like India and Indonesia this species base for commercial beekeeping is being squeezed with the expansion of the introduced $A$. mellifera. In India there was hardly any beekeeping with $A$. cerana in Punjab, Haryana and plains of Uttar Pradesh but $A$. mellifera is doing very well in these areas.

The Indian race of the species is $A$. cerana indica and there are many distinct strains present in different goeographical regions. The existence of strains is surmised on the bases of biometrical characteristics. Kshirsagar (1980) described the importance of biometrical characteristics for characterization of Apis cerna indica at species ecotypes or strains level. Tongue length of Apis indica is $5.25 \mathrm{~mm}$ in bees of Kulu, Himachal Pradesh. Kapil (1956) compared the biometrical characteristics of workers of plains (Allahabad, $26^{\circ} \mathrm{N}$ latitude) and hills (Nagrota, $32^{\circ} \mathrm{N}$ latitude) races of the species. The differences between the two varieties were significant for each characteristic except for the number of hooks on the hammuli and cubital index. Narayanan et al. $(1960,1961)$ reported that tongue length was $4.84 \pm$ $0.05 \mathrm{~mm}$ for leather coloured plain race, $5.16 \pm 0.01 \mathrm{~mm}$ for leader grey hill race and $4.9629 \pm 0.0041 \mathrm{~mm}$ for bees from Pusa (Bihar). Number of wing hooks were $16.91 \pm 0.09$ and $18.26 \pm 0.06$ for the plains and hill races, respectively. The studies led the authors to conclude that three races (or biological varieties) of Apis indica i.e Himalayan, Gangetic plains and South Indian could be distinguished. Information on morphometric charącters of bees from different regions is now available (Mattu and Verma, 1983, 1984a, 1984b; Kshirsagar and Ranade, 1981; Kshirsagar, 1981; Singh, 1984).

This bee lives in the cavities of tree trunks, hollows of rocks, poles and other covered places. It can be domesticated in all kinds of hollows and recesses. Hollowed out logs, wooden boxes, packing cases, kerosene tins, mud receptacles, earthen pitchers, wall recesses and unused almirahs are the common abodes (Fig.5). Worker comb cell is 4.3-5.0 mm in diameter. Drone cells are 1.2 times larger in diameter than worker cells. Smaller hives are used for Apis cerana indica in most parts of India. The build-up capacity is low but in Kashmir 'Langstroth' type of hives are used. Brood-rearing in a bee colony determines the colony's strength. Sharma (1948) recorded the egg laying of 500-600 per day. Kapil (1957) observed 6178 and 8178 sealed cells and the egg laying rate was worked out to be 500-700 eggs per day. Sharma (1958) compared the egg laying capacity of plains and hills races of Apis cerana indica. The maximum egg laying in hill race was about 1,000 eggs per 24 hours compared with 600 for golden variety of plains. But Kashmir bees a re very fertile and Shah and Shah (1981) found the egg laying between January and October to be 1,603 eggs per day. This egg laying rate is comparable to Apis mellifera.

Apis cerana indica is a bee with gentle temperament and it responds to smoking. It is frugal in habits but lack of flora is quickly reflected into absconding. It also has a strong tendency for swarming; a colony may issue up to 5-6 swarms in a year. Management and manipulation practices to prevent and control swarming also do not always work. Due to incessant 


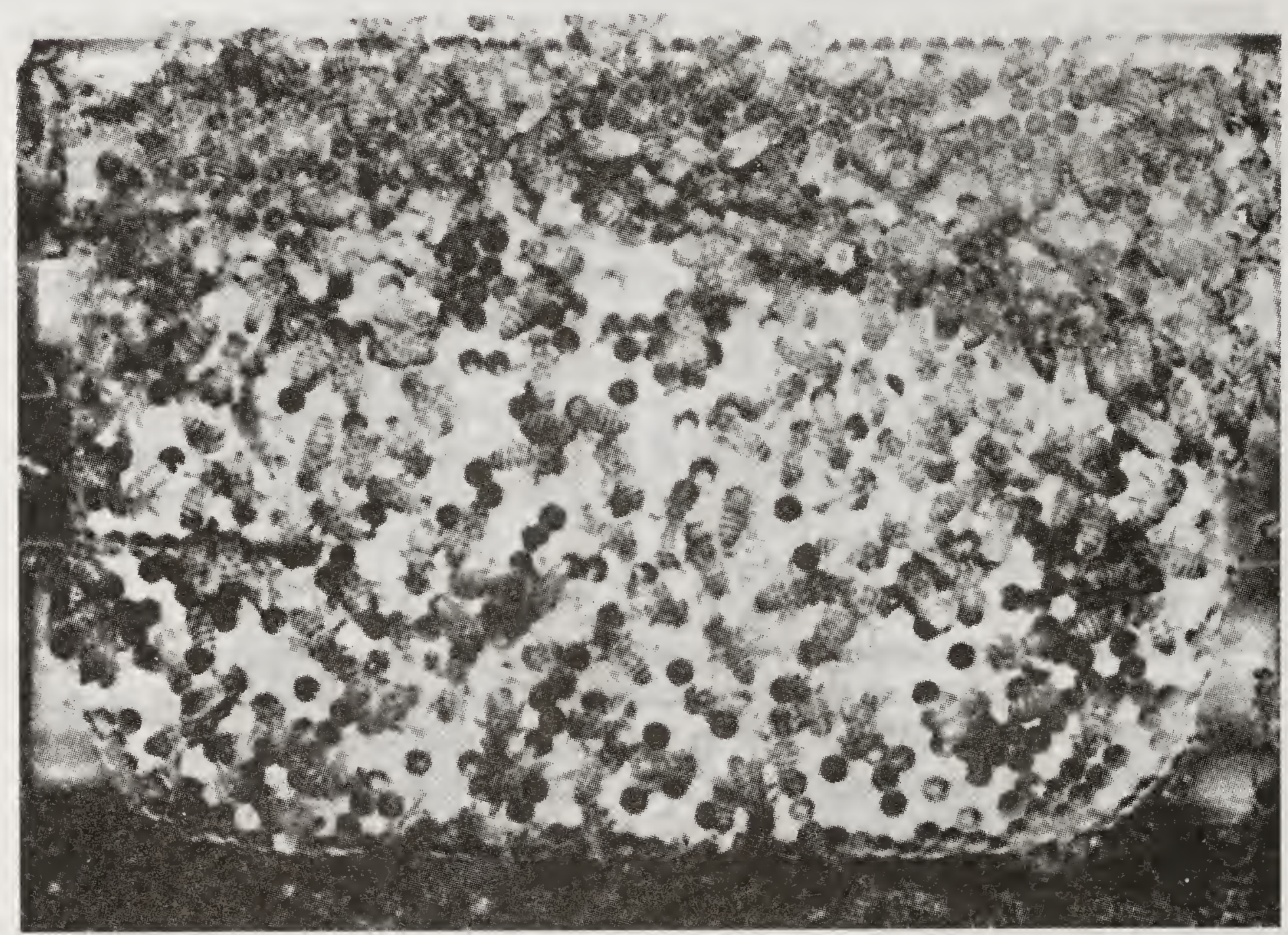

Flg. 5. Apis cerana indica bees in a comb; busy with their hive duties.

swarming, ravages of bee enemies, lack of honey flora and resultant absconding, one comes across a large number of weak colonies. It is poor propolizer and practically no propolis is brought to the nest for reinforcing the combs or sealing the cracks and crevices etc., therefore, wax moth does considerable damage. Because of small size, short foraging distance, absconding, swarming etc. this species is a low honey-yielder. On an average a colony yields $3-5 \mathrm{~kg}$ of honey per year in plains but the yields are as high as $20-25 \mathrm{~kg}$ in Kashmir. The selective breeding does help in improving the desirable traits but of little practical value because of no control on parentage.

European honeybee (Apis mellifera Linn.). This species is found all over Europe and has spread to other continents also during the last five centuries. Now it is found almost in every country. There are many well recognized races and strains of mellifera. Tongue length varies from 5.5 to $7.2 \mathrm{~mm}$. The bee is similar in habits to the Indian honeybee in that it builds parallel combs in hollows of trees, walls or in shady places. Geographical races greatly differ in appearance. ${ }^{\circ}$ Four European races, viz., Apis mellifera mellifera, Apis mellifera ligustica, Apis mellifera carnica and Apis mellifera caucasica are most important for beekeeping. Apis mellifera ligustica (Fig. 6) is considered to be the best and has been introduced in many countries. It has many desirable traits. It maintains a prolific queen, swarms less, has gentle temperament and is good honey-gatherer. This race has achieved a great success in some states of India where this has proved to be superior performer than Apis cerana indica. 


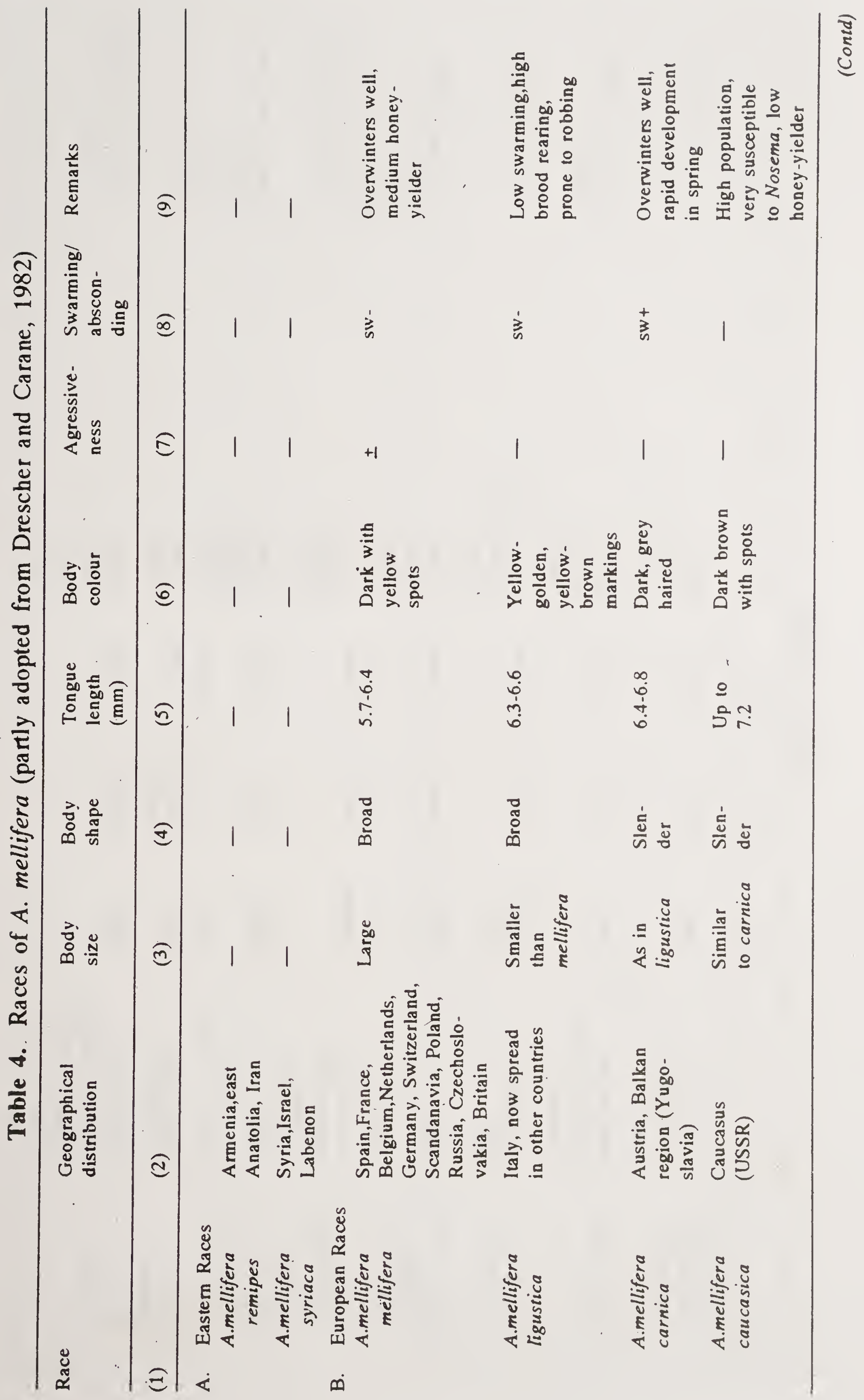


HONEYBEES AND THEIR MANAGEMENT IN INDIA

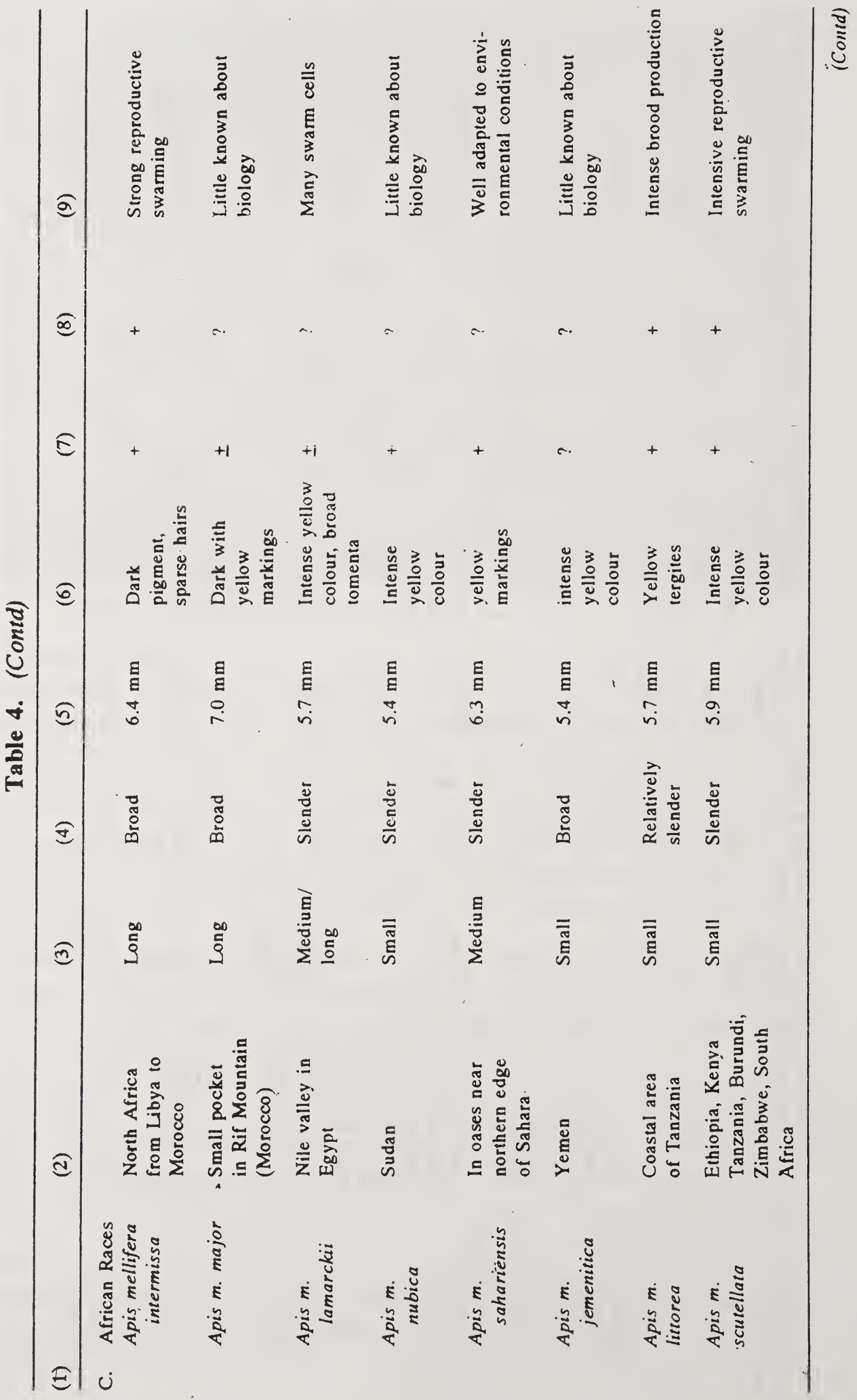




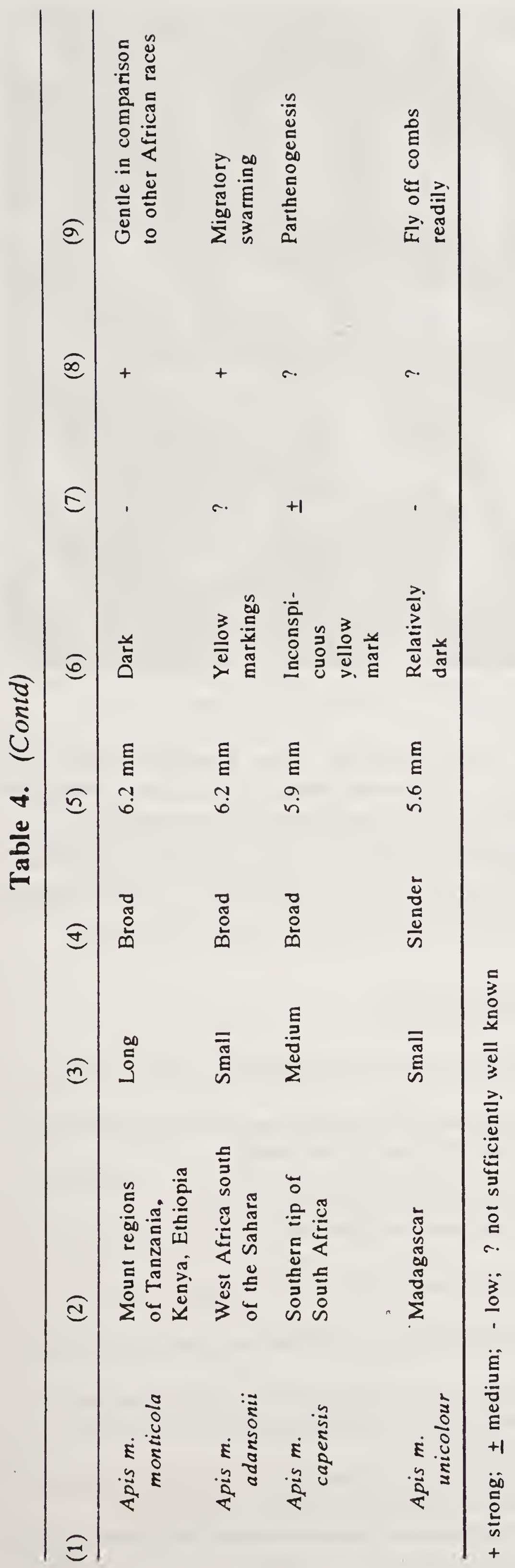




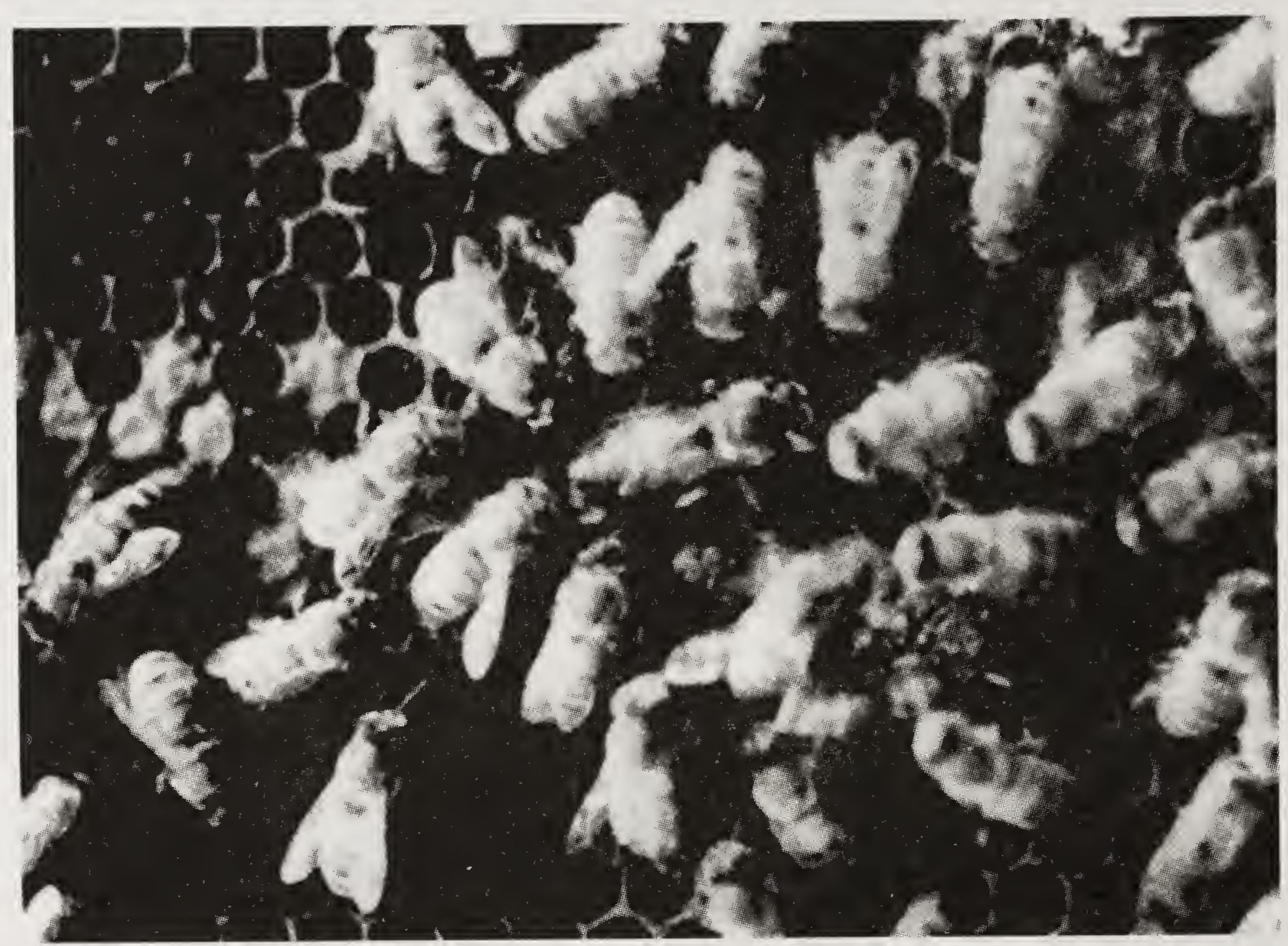

Fig. 6. Apis mellifera queen with attendant worker bees.

Other honeybee species. Three more species of genus Apis have now been recognized to exist (Ruttner et al., 1990 and Wongsiri et al., 1990). A koschernikovi is found in south-east Asia and it appears to be similar to $A$. florea. Another closely similar species known to exist at least in Thailand, Malaysia, and southern China peninsula is A. andreniformis. A. laboriosa is widely believed to be a separate species and it looks like $A$. dorsata.

\section{REFERENCES}

Batra, S.W.T. 1977. Bees of India(Apoidea), their behaviour, management and key to the genera. Oriental Insects $11(3)$ : 289-324.

Deodikar, G.B. and Thakar, C.V.1966. Cytogenetics of Indian honey bee and bearing on taxonomic and breeding problems. Indian J. Genet. Pl. Breed. 26 A : 386-93.

Drescher, W. and Crane, E. 1982. Technical co-operation activities. Beekeeping - A Directory and Guide. German Agency for technical co-operation, Eschborn, pp 166:

Fletcher, L. 1952. Apis dorsata, the bambara or giant bee of India and Ceylon. Bee Craft 34(9):139. 40.

Kapil, R.P. 1956. Variations in biometrical characters of the Indian honeybee (Apis indica F.). Indian J. Ent. 18(4): 440-57.

Kapil, R.P. 1957. The length of life and the brood-rearing cycle of the Indian bee. Bee Wld. 38(10) : 258-63.

Kshirsagar, K.K. 1980. Morphometric studies on the Indian hive bee, Apis cerana indica F.1. Morphometric characters useful in identification of intraspecific taxa. Proc. 2nd Int. Conf. Apic. Trop. climates, New Delhi, 1980, 254-61.

Kshirsagar, K.K. 1981. Morphometric studies on Apis cerana indica F. worker.III. Effect of geographical position on morphometric characters. Indian Bee J. 43 (1) : 1-5.

Kshirsagar, K.K. and Ranade, D.R. 1981. Morphometric characterization of Indian hive bee, Apis cerana indica F. (Apidae, Hymenoptera) worker. J. Univ. Poona Sci. Tech. Sec. 54 : 101 -20. 
Mani, M.S. 1962. Introduction to High Altitude Entomology. Methuen Co., London, 302 pp.

Mattu, V.K. and Verma, L.R. 1983. Comparative morphometric studies on the Indian honeybee of the north-western Himalayas. 1. Tongue and antenna. J. apic. Res. 22(2) : 79-85.

Mattu, V.K. and Verma, LR. 1984a. Comparative morphometric studies on Indian boneybee of the north -western Himalayas. 2. wings. J. apic. Res. 23(1) : 3-10.

Mattu, V.K. and Verma, L.R. 1984b. Co mparative morphometric studies on the Indian hone ybee of north-western Himalayas.3. Hind leg, tergites and sternites. J. apic Res. 23(3) : 117-22.

Mishra, R.C., Dogra, G.S. and Gupta P.R. 1977. An attempt to domesticate Rock bee, Apis dorsata F. Indian Bee J. 38(1/4) : 20-22.

Muthappa, B.M. 1979. Rock bee culture in forests. Myforest 15(3) : $189-99$.

Muttoo, R.N. 1952. Tree apiaries. Indian Bee J. 14 : 87-89.

Muttoo, R.N. 1957. Some so called peculiarities of behaviour of Indian honeybees as compared to the European bees. Indian Bee J. 19(3/4): 62-64.

Narayanan, E.S., Sharma, P.L. and Phadke, K.G. 1960. Studies on biometry of the Indian bees. 1.Tongue length and number of hooks on the hind-wing of Apis indica.Indian Bee J. $22(7 /$ 9) : 58-63.

Narayanan, E.S., Sharma, P.L. and Phadke, K.G. 1961. Studies on biometry of the Indian bees.III. Tongue length and number of hooks on the hind-wings of Apis indica F. collected from Madras state. Indian Bee J. 23(1/3) : 3-9.

Reddy, C.C. 1980. Studies on the nesting behaviour of Apis dorsata F. Proc. 2nd Int. Conf. Apic Trop. Climates, New Delhi, 1980, pp 595-99.

Shah, F.A. and Shah, T.A. 1981. Egg-laying capacity of Kashmir bee. Apis cerana. Bee Wld. 62(3) : 114-15.

Sharma, P.L. 1948. Studies on seasonal activities of Apis indica F. at Lyallpur. Indian Bee J. $10: 20$ 23.

Shrma, P.L. 1958. Brood-rearing activity of Apis indica F. and egg-laying capacity of its queen. Indian Bee J. 20(11) : 166-73.

Singh, M.P. 1984. Morphometric Studies on Indian Honeybee, Apis cerana indica F. of NorthEastern Himalayas. M.Phil. Dissertation, H.P. Univ., Shimla, India, 129 pp.

Thakar, C.V. and Tonapi, K.V. 1961. Nesting behaviour of Indian honeybees. 1. Differentiation of worker, queen and drone cells on the combs of Apis dorsata Fab. Bee Wld.42(3) : 61 -62, 72.

Thakar, C.V. and Tonapi, K.V. 1962. Nesting behaviour of Indian honeybees. II. Nesting habits and comb cell differentiation in Apis florea Fab.'Indian Bee J. 24(1/3) : 27-31.

Whitecombe, R.P. 1982. Experiments with a hive for little bee: some observations on manipulating colonies of Apis florea in Oman (part I). Indian Bee J. 44(3) : 57-63. 


\section{MORPHOLOGY, ANATOMY, COLONY ORGANIZATION AND LIFE CYCLE}

THE honeybee belongs to family Apidae of order Hymenoptera. It shares the general characters of class Insecta. But the organ systems are variously modified to lead a specific life, that is food habits, social life and other ways of life. A brief account of different organs and the way they have been modified to perform a particular function, as essential for understanding the activities of bees, is given below.

\section{Morphology}

Head. The head (Fig.7) of adult bee bears a pair of geniculate antennae. The third portion (flagellum) has many sensory structures which are mainly chemo- and mechano-receptors. The compound eyes are placed on the lateral sides of the head. Bees can distinguish colour but are red blind. They can perceive ultraviolet rays but cannot perceive the red light spectrum that is beyond $620 \mu$ wavelength. Bees can also see polarized light. It is well-known that bees communicate the food sources with reference to the position of the sun but even in cloudy days or when the sun is obscure the bees perform communication dance with reference to the position of the sun and this is done by receiving polarized light. In the top portion of head capsule the bee has three ocelli. The ocelli perceive only the degree of light and do not form an image on the retina.

Two mandibles are attached to ventro-lateral part of the head capsule. The mandibles differ in the three castes of honeybee (Fig.7). In workers the mandibles are narrower in the middle and broader at the base and at distal end. Each mandible has a channel, both sides of which have fringed hairs. This channel leads to a groove which ends at the opening of mandibular gland. The mandibles are used for grasping, scraping pollen from anthers, feeding pollen, and manipulating wax during comb building. Mandibles of queen differ from those of workers in that they have bilobed distal end and there is no groove from the mandibular gland opening. Mandibles of drone are smaller in size and have faint groove, covered with long hairs, with an apical projection.

The mouth parts in worker bees are modified for sucking and lapping (Fig.8). The proboscis or tongue, which is used for ingesting liquids, is formed by median labium and two lateral maxillae. Labium has long glossae. At the time of sucking food, galeae of maxillae and labial palpi form the anterior and posterior coverings and are appressed together with paraglossae forming the axial part of the food tube. The two paraglossae are united together. The tongue has a deep grove with a partition made by a rod which is curved backwards. One canal serves as salivary canal through which the 


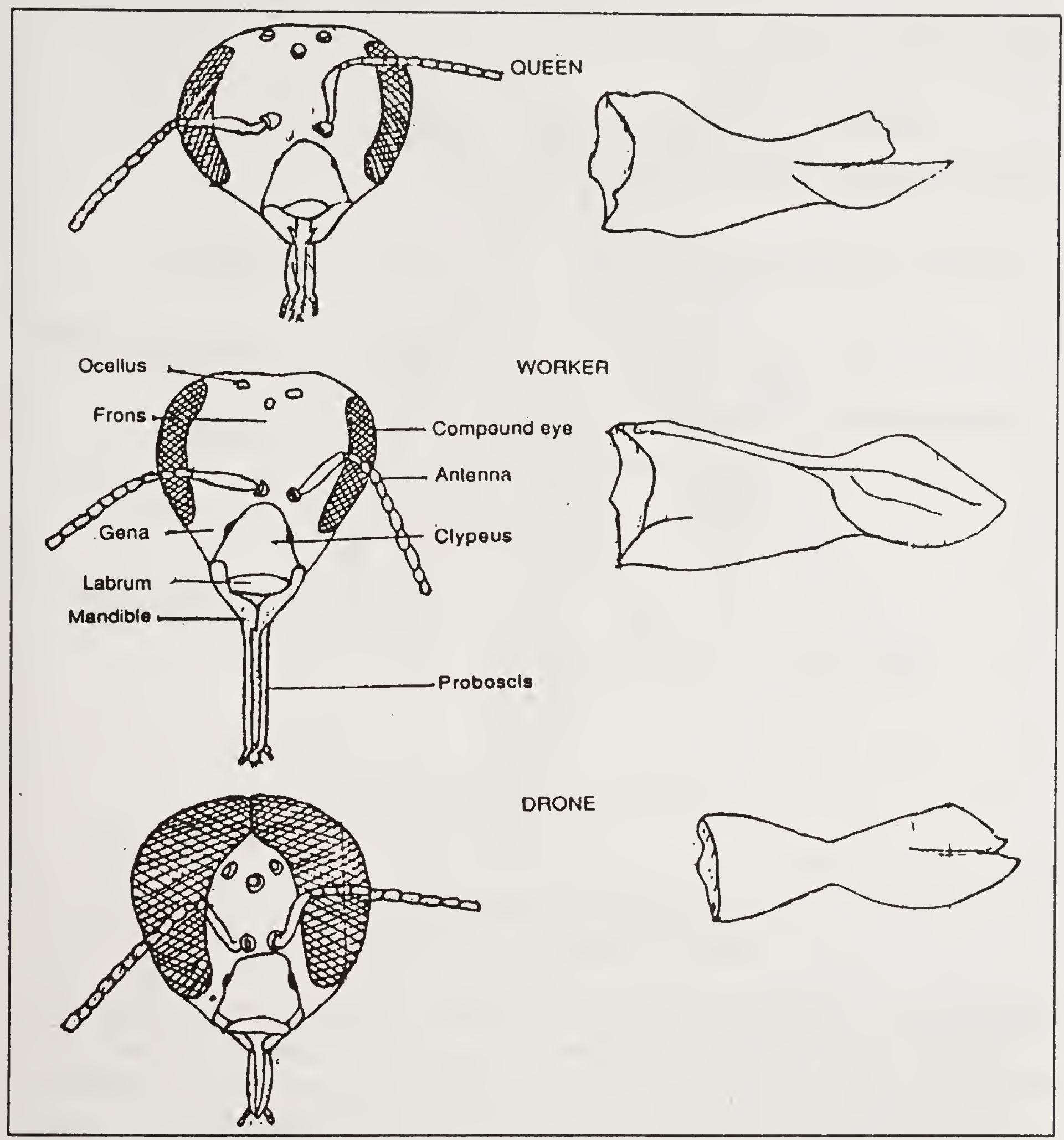

Fig. 7. Head capsules and mandibles of castes of honeybees.

saliva is ejected on the food before feeding and the food is ingested through the second canal. The tongue has a spoon shaped lobe at the end. With the lapping motion of the tongue the liquid food is drawn into the food canal of the proboscis and the food channel leads to mouth cavity. The preoral cibarium and postoral pharynx form sucking pump. With the help of sucking pump the food is forced into the oesophagous and honey stomach.

Worker bees feed the young larvae and the queen with the glandular food called 'royal jelly'. The food is secreted by hypopharyngeal glands which are long coiled strings of small lobes and are present in the head region. The brood food appears at the base of the open mandibles of the nurse bees.

Thorax. As is common with other insects the second body region, thorax, consists of three segments and is joined to the third region, abdomen, by a narrow propodeum. Thorax carries the organs of locomotion, the legs and wings. The leg of honeybee is composed of basal coxa, femur, long tibia, tarsus and pretarsus. Tarsus is subdivided into tarsomeres and small pretarsus 


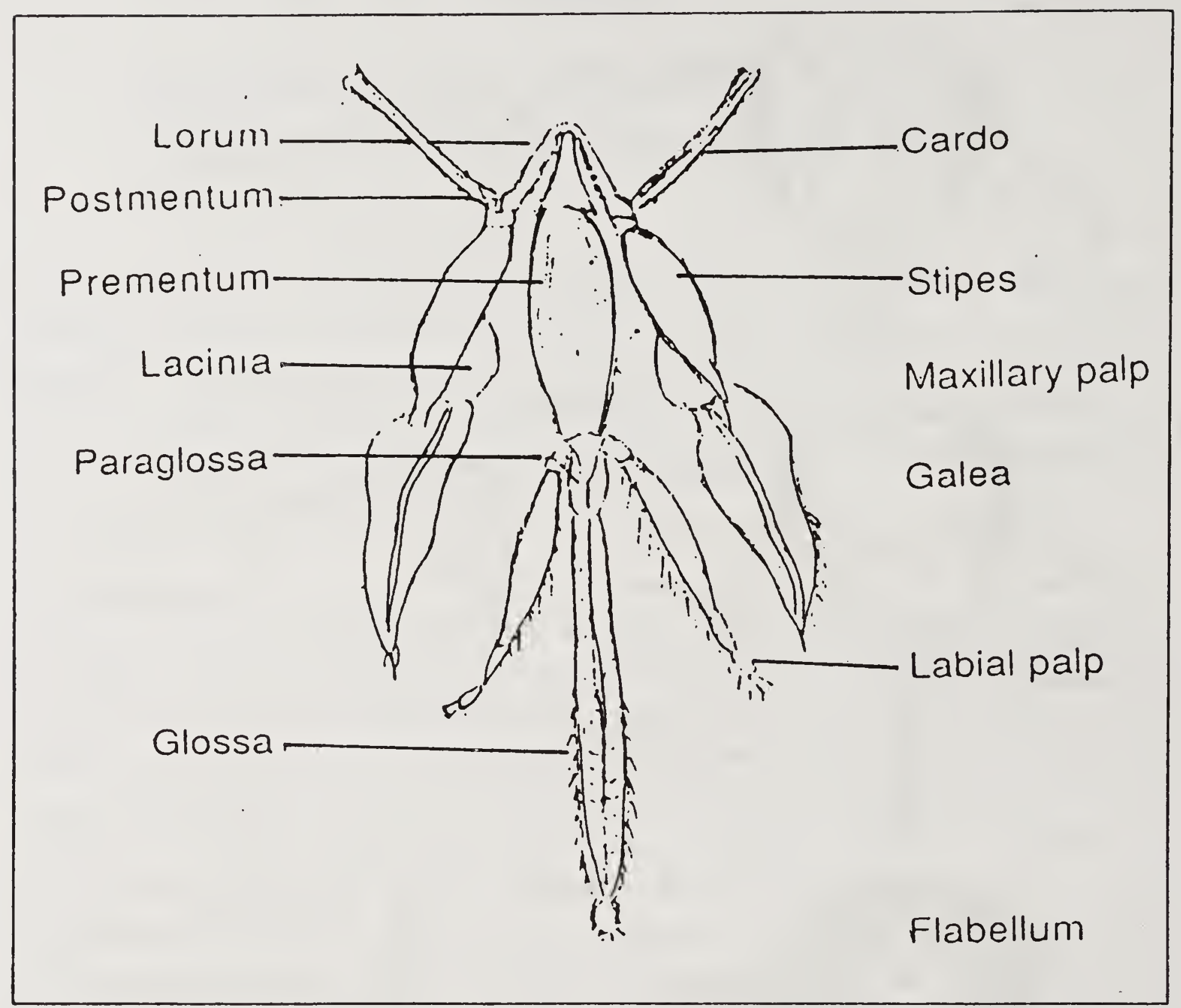

Fig. 8. Mouth parts of worker bee.

bears the claw. Besides locomotion the legs in honeybees are also modified to perform other functions. Prothoracic legs serve as antenna cleaner. The basal part of the basitarsus has a notch and small lobe projects from the distal end of tibia. The notch has two rows of spines. The flagellum of the antenna is placed on the notch and the tarsus is flaxed against tibia. The antenna is drawn upward and is thus cleaucd in between the notch and the projecting clasp. The modification is met with in all the three castes of honeybees. Hind legs in worker bees are modified for pollen and propolis collection (Fig.9). The tibia has double row of curved hairs, the space enclosed in between these is called corbicula or pollen basket. Adjacent margins of tibia and tarsus have notch. Notch on the tibial margin has a row of stiff spines and the opposite trasal margin is modified into a lip called auricle which is also fringed with hairs. Hairy brushes on the tarsi of fore and middle legs collect pollen sticking to head and thorax regions, respectively. The pollen from fore leg is transferred to middle leg of the respective'side. The spines on the tibial end of the hind leg brushes the pollen from opposite leg. The pollen falls on flat surface of auricle. By the upward movement of tarsus the pollen on the auricle is pressed against the outer surface of the tibia and thus a pollen load is accumulated.

Abdomen. The abdomen in adult worker and queen apprears to be six segmented, segments 8 to 10 are reduced in size whereas first is transferred 


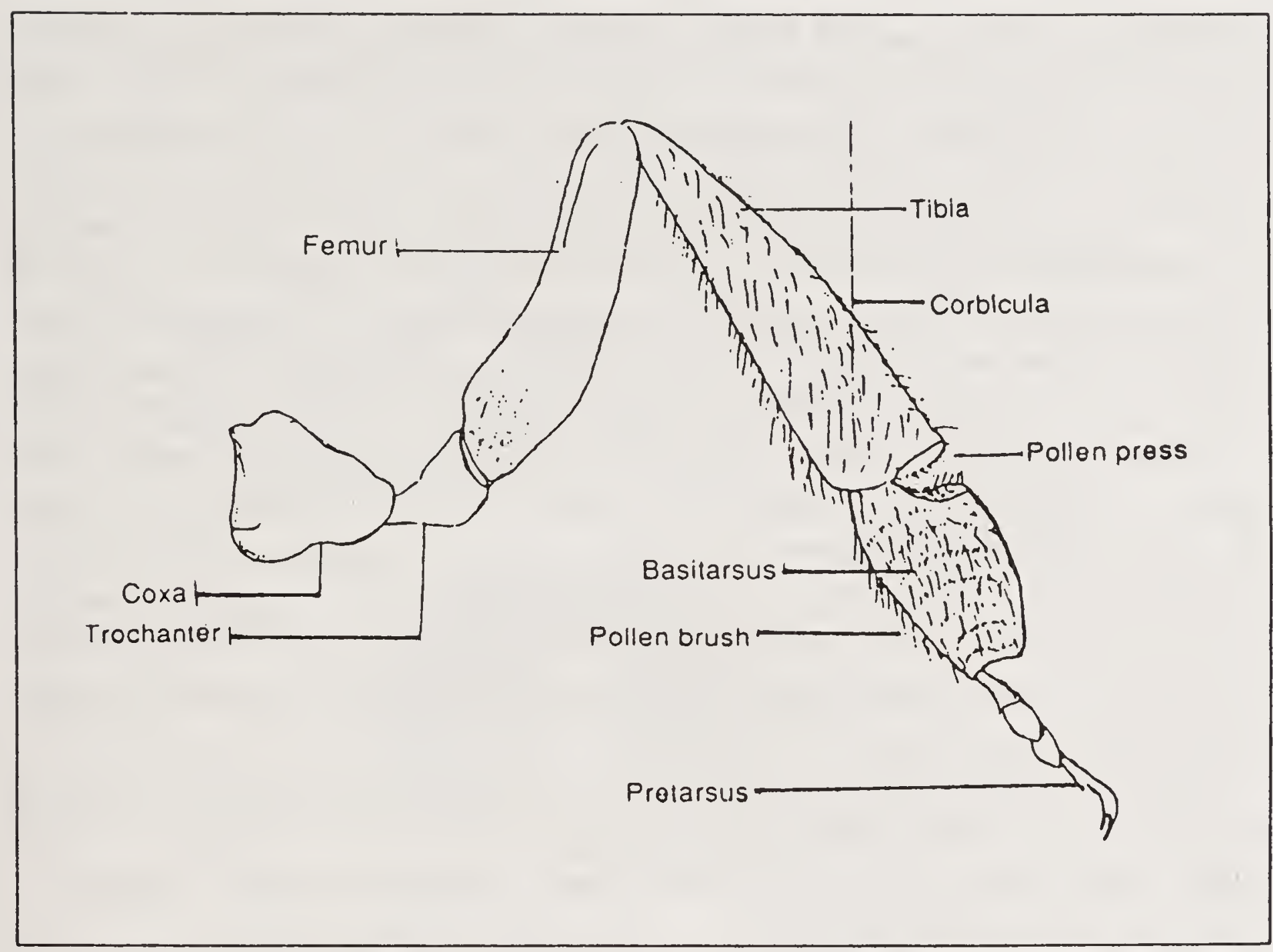

Fig. 9. Hind leg of worker bee.

to thorax during pupal stage. The abdomen bears sting, wax and scent glands and genitals and also contains the principal viscera inside.

Sting. In worker bee the egg-laying apparatus (ovipositor) is modified into a sting. Sting is formed by three long stylets attached to the bulb. The ends of the stylets have two lancets which are hollow and when in contact with each other, they form a poison canal. The bulb at the base of shaft made by lencets is supplied by poison sac which is the reservoir of poison gland. Venom is injected into the body of the victim with each movement of the stylet. These movements continue even after the sting has been inserted. The la ncets bave curved barbs and the sting apparatus is broken off from the bee's body in the attempt to pull it out. Queen has well developed poison glands with large poison sac but the lancets lack the curved barbs and she uses it for stinging the rival queens.

Wax glands. Wax glands are situated in the sternites of 4 to 7 abdominal segments. These are polished plates (mirrors) and formed by the modification of epidermis. The wax glands become active in the worker bee at the age of 14 to 18 days. Wax is secreted in liquid form which solidifies into thin flakes.

Scent glands. The scent glands are present in the thin membrane connecting the last two abdominal terga. Bee bends ber abdomen and exposes the membrane to produce the scent. The odour produced by the cells is derived from scented waste products of metabolism.

\section{Anatomy}

The first part of the digestive tract consists of mouth, pharynx and 
oesophagus with expanded boney stomach. Following the boney stomach (sac) is a valve which regulates passage of food into ventriculus. The valve can remove the pollen from nectar and by the action of this valve, nectar can be retained in honey sac while the pollen passes to the ventriculus. Digestive enzymes are released by the epithelial lining of the stomach. Digested sugars are absorbed into the blood through the walls of the ventriculus. Digested proteins (a mino acids) are absorbed in the small intestine. The small intestine leads to rectum which holds the faeces until it is discharged during flight.

Honeybee has open circulatory system formed by the heart and the aorta. The blood is pumped from the five-chambered heart into the aorta. The chambers of the heart have ostial valves which allow the blood to enter into the heart but backward movement to body cavity is prevented. The blood is poured into the body cavity below the brain at the anterior opening of aorta. The organ systems freely bathe in the blood in the body cavity. The muscle movement of dorsal diaphragm helps in pumping the blood, whereas ventral diaphragm beats in backward direction.

Respiration takes place through spiracles present on lateral sides of various segments of the body. Spiracular openings are attached to tracheae which ramify into trancheoles. The tracheae and tracheoles supply oxygen to respective segments of the body.

Excretory system is of generalized type. Many thin tubes called Malpighian tubules, extend in the body cavity around various organs. They collect waste metabolites from the blood present in the body cavity.

Brain and ventral nerve cord constitute the central nervous system. Brain has three distinct parts; the anterior most having optic lobes, antennal lobes and mushroom bodies. Mushroom bodies a re the centres of instinct and memory co-ordination. Ventral nerve cord has seven nerve centres (ganglia). These centres innervate the various body regions. Sensory nerves extend from the receptive cells of the sense organ to central nervous system. Eyes are the important sense organs. On the body of the bee, there are innervated hairs which perceive the mechanical stimulus. Small thin-walled peg-like hairs can perceive odour.

Female reproductive system is fully developed in queen but in workers the system is greatly reduced (Fig.10). Two la rge ovaries have a number of egg tubules or overioles which lead to lateral oviducts. The two lateral oviducts join posteriorily to form median oviduct which leads to vagina. Spermatheca is a pouch like structure and serves as store house for sperms. The spermatheca is connected to vagina by a spermathecal duct. Tongue like valve fold closes the opening of median oviduct when the sperms are pushed into the spermatheca. Bursa copulatrix accomodates penis at the time of copulation. The valve fold when raised, makes the micropyle of the egg to come in contact with the sperm released from the spermatheca and the fertilization takes place. The ovipositor which is modified into a sting helps in depositing the egg. Soon after mating, the sperms migrate from the vagina to the spermatheca which stores about five million spermatozoa. These spermatozoa remain viable, get nourishment during storage and are released in small 


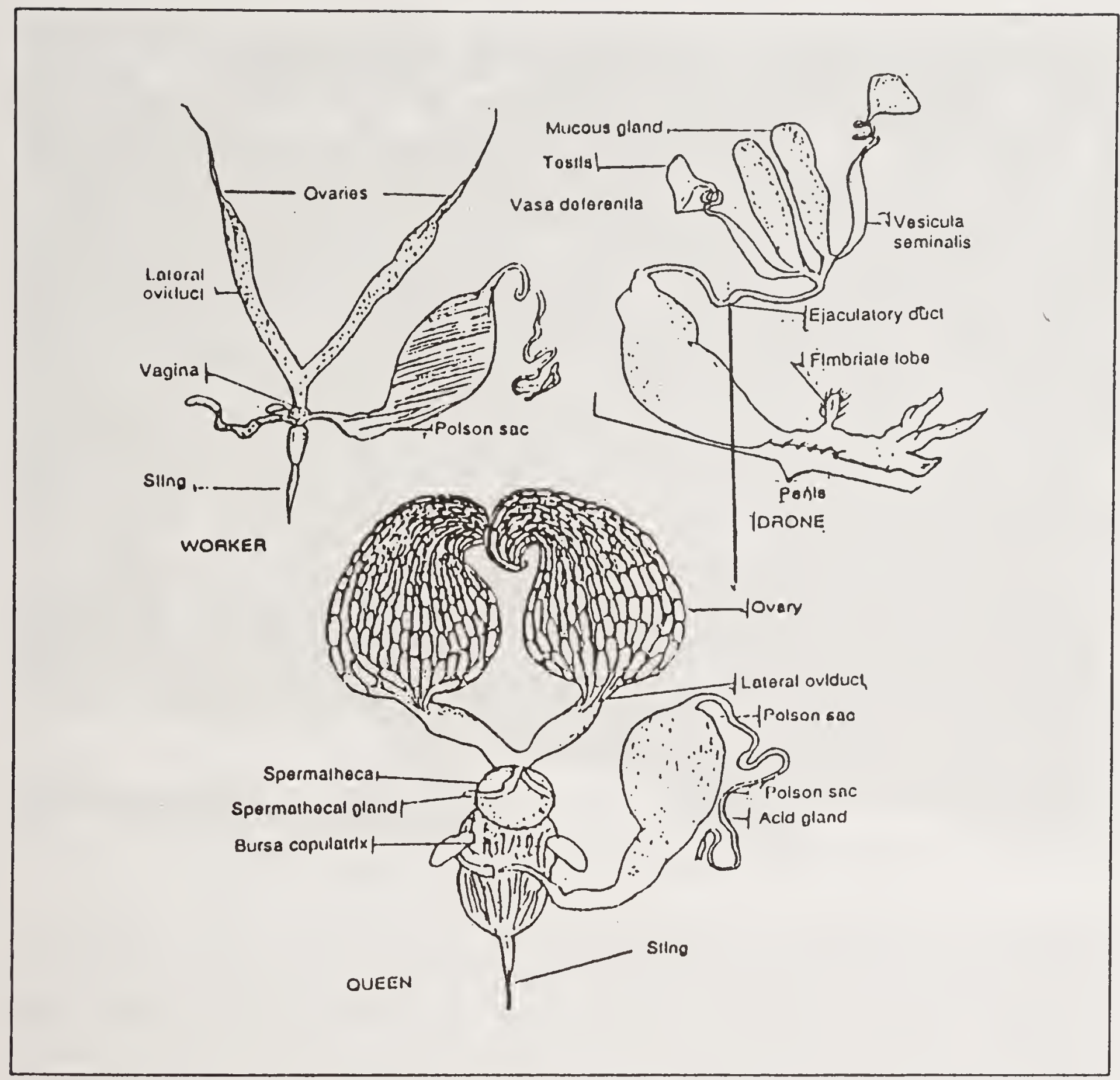

Fig. 10. 'Reproductive organs of drone, worker and queen.

numbers for the fertilization of the eggs. Male reproductive system has paired testes with one vasa deferentia each . Both the vasa defrentia join posteriorly and form an ejaculatory duct which leads to penis. Two mucous glands unite with ejaculatory duct. On an average each drone produces $1 \mathrm{~mm}^{3}$ semen in A. mellifera and $0.16 \mathrm{~mm}^{3}$ in $A$. cerana indica.

\section{Colony organization}

Honeybees are social insects and live in colonies with a highly organized system of division of labour. There are three castes: queen, workers and drones (Fig.11). In a normal colony there is one queen, 10,000 to 30,000 workers and a few hundred drones. In $A$. mellifera colony the number of workers before honey flow may go to $60,000-70,000$.

Queen. The queen is the only perfectly developed female and is the mother of the colony. In the peak of the season, she may lay large number of eggs in a day, weight of which is almost twice the weight of her body.

She mates with the drones, the male bee, in the air only once in her lifetime. The stock of male sperms received during mating is preserved in a pouch-like structure, spermatheca, in her body. She draws upon it for a long time (which may be two or three years) to regulate the sex of the off-springs. 


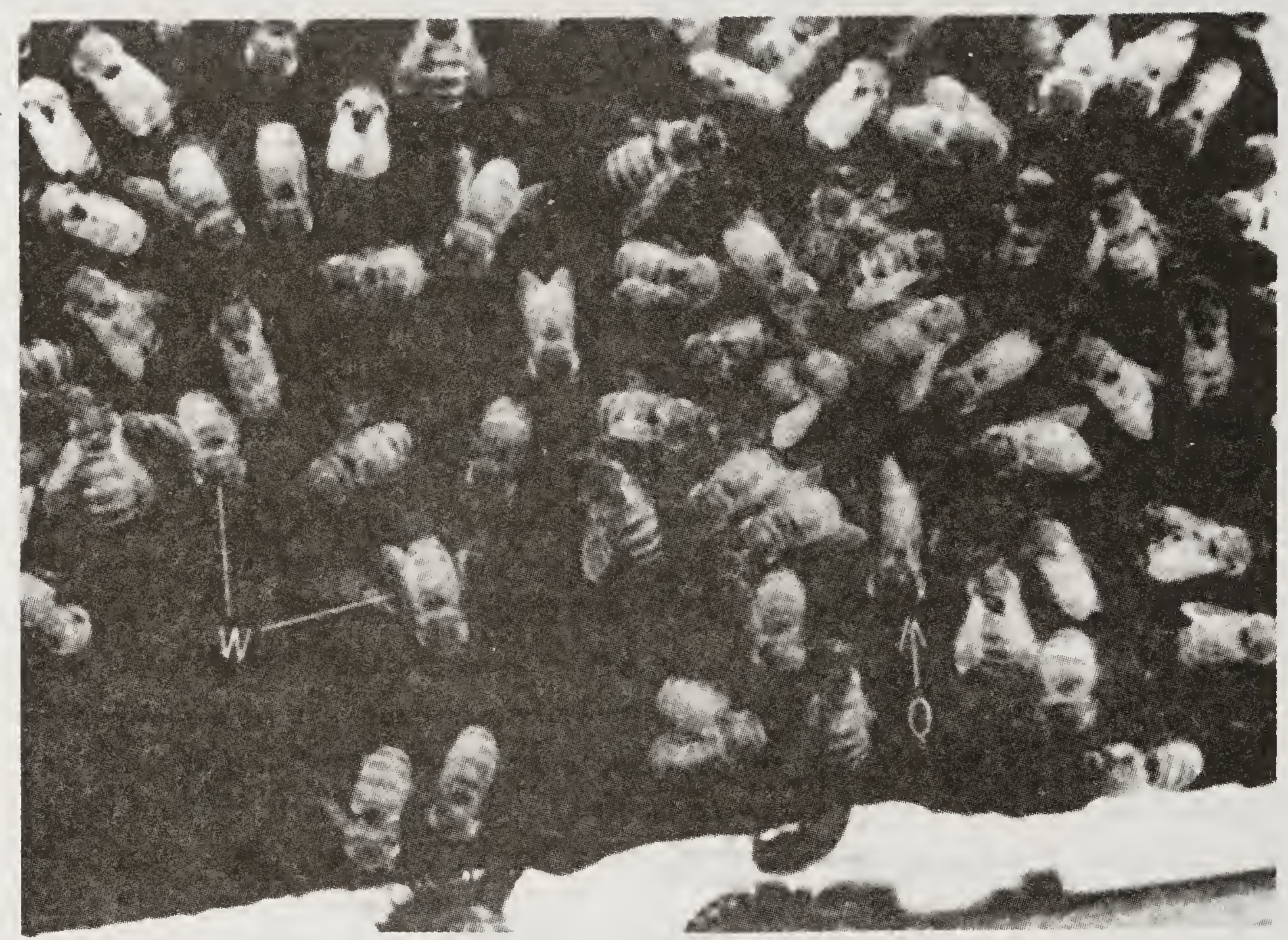

Fig. 11. Honeybee colony with a queen, drones, workers.

She can lay fertilized or unfertilized eggs at her will. From the former, workers and sexual females or potential queens and from the latter drones are produced. The differentiation in the workers and the queen is not due to the quality, as previously believed, but to the quantity of the food fed to the larvae. The partial stravation, from about the third day, of the female larvae that are reared in worker cells, results in their differential growth and they become workers instead of queens, which they would have become if they would have been lodged in the larger queen cells and had constant access to more food. The queen in her rounds over the combs lays eggs in the worker, queen or drone cells. The eggs are generally laid in concentric circles. As the old queen shows signs of decline in laying fertilized eggs or if a colony is under swarming, supersedural or emergency impulse, new queens are reared in specially prepared queen cells. On emergence a new queen roams about on the combs, feeds herself on honey and takes one or more orientation flights out of the hive after 5 to 10 days of emergence. On her mating tlights she is followed by drones and have multiple matings in one or more days. Her mate dies during the act of copulation and falls on the ground. The queen returns to the hive with the mating sign, the male reproductive organ attached to her reproductive opening, which is removed by the worker bees. After 2 to 4 days she starts laying eggs, first slowly then vigorously. The number of eggs laid depend upon the amount and kind of food she receives from the workers and the availability of other favourable conditions for egg laying and brood rearing.

The queen is heavily worked individual and quick!y transforms the food, 
given to her by the workers, into eggs. She, however, lacks the motherly instinct and the function of nursing the young ones is performed by the worker bees. An $A$. mellifera queen lays up to 1,800 eggs per day during active brood-rearing season but $A$. cerana indica queen lays from 500 to 1,000 eggs per day (Kapil, 1957; Sharma, 1958). Number of eggs laid by queen of Indian bees in Kashmir is comparable to A. mellifera (Shah and Shah, 1981). Egg-laying rate diminishes with the age and in failing queens.

Worker. The worker bees are imperfectly developed females. Unable to reproduce, but possess all the maternal instincts. They are responsible for the maintenance and welfare of the colony. Division of labour in worker bees is on a physiological basis which is explained elsewhere in this book.

A worker bee has no individual existence and throughout her life she labours for the good of the colony. The worker bee is capable of performing a definite amount of work and she dies when that is accomplished. Consequently, during honey flow season when she has to work at a tremendous pace, she lives only for about six weeks but during off season., as in winter or in cold climate her life extends up to six months. At Coimbatore in Tamil $\mathrm{Nadu}$, which has equitable climate, $A$. cerana indica worker lives for 50 days, the extremes being 44 and 54 days (Cherian and Mahadevan, 1945). Kapil (1957) found the life span to be 25-42 days from January to April and 45 days in May in Uttar Pradesh.

Drone. The only function of the male bee is to mate with the queen. Drone has short tongue but does not collect food from flowers. The tongue is used to receive food from worker bees. Drone has no wax and scent glands. Generally it takes 3 to 6 worker bees to feed a drone. Drones are reared and tolerated during the breeding season in spring and in some places in autumn, when new queens are to be mated. They are driven out of the hive to die of starvation when not needed. The normal life span of an $A$. cerana drone has been worked out to be 57 days in Tamil Nadu (Cherian and Mabadevan, 1945).

The three castes of bees depend on each other for their existence. The lonely worker bee may not live for more than two or three days under the best of simulated environmental conditions. The queen bee also cannot form or even start a colony because she is physically incapable of secreting wax, building a comb, collecting food from the field or rearing brood. In fact, she requires the services of several wokers to feed and groom her and to do other jobs for her. A drone would not last beyond four hours without food. A normal colony must have a fecundated queen capable of laying plenty of fertilized eggs and a large number of workers of varying age as the latters' fitness to do different tasks depends on their age. A colony is termed 'weak' or 'strong' according to the number of worker bees it possesses. A colony of Apis cerana indica bees with 10,000 to 15,000 bees $(906-1359 \mathrm{~g}$ ) is considered an average colony at higher altitudes. Drones are not necessary to the normal welfare of a colony but they are needed only during the mating seasons to fecundate virgin queens. 


\section{Development}

The honeybee undergoes an indirect development (metamorphosis). The four stages of development are: the egg, the larva, the pupa and the adult. Duration of development of worker bee of $A$. cerana indica is given in Table 5 (Mishra and Dogra, 1980). The mother queen glues or sticks a short delicate white tubular egg, slightly curved on one side, at the bottom of the cell of a comb. From this egg, a tiny, white larva hatches out and feeds voraciously on the food supplied by the nurse bees. When fully fed it weighs more than 1,500 times of its original weight. The cell is capped by the

Table 5. Time sequence of instars and moults in the worker honeybee, $A$. cerana indica

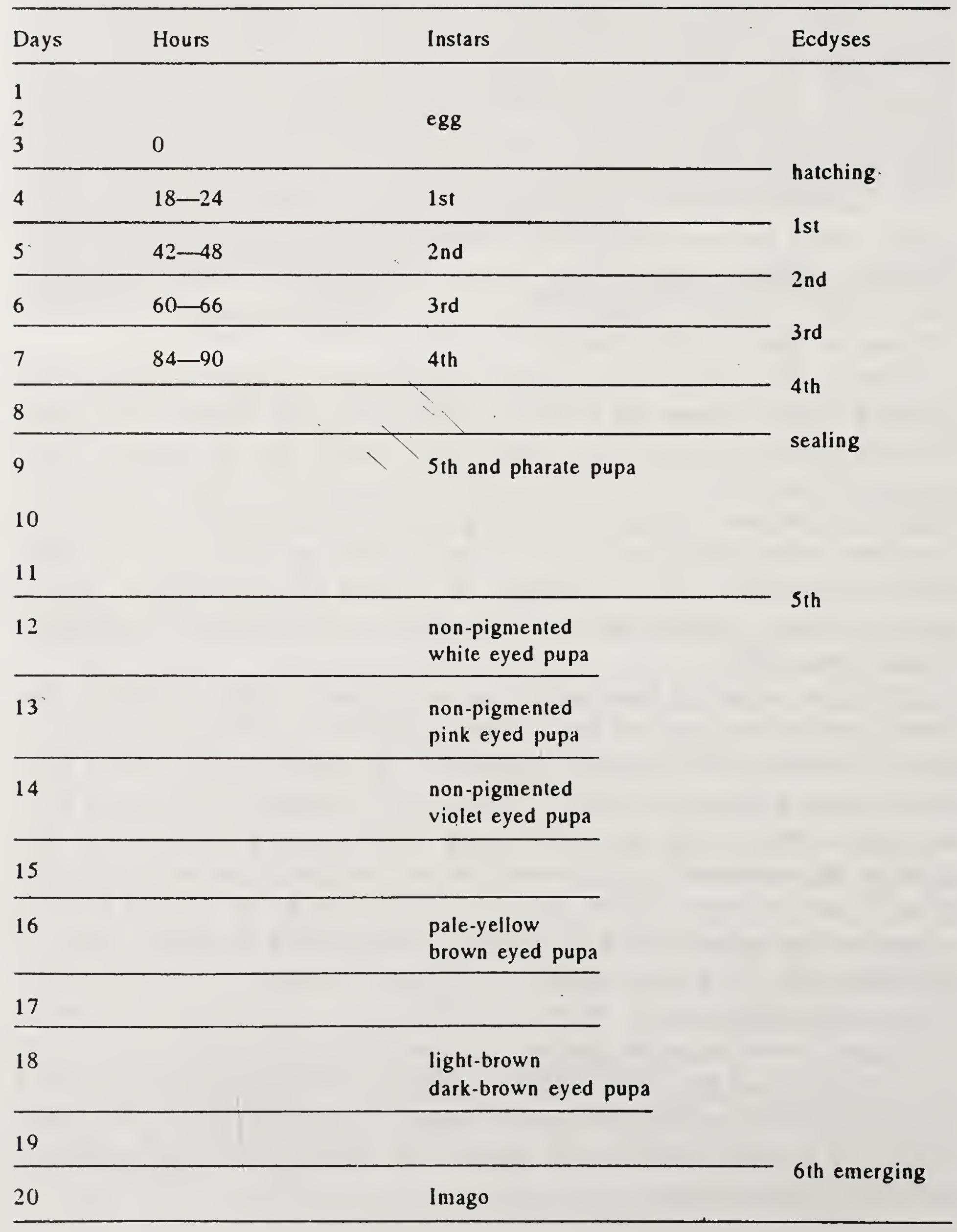


worker bees with a waxen cover. The fully fed larva spins a cocoon in the cell and enters a period of rest during which it transforms itself into pupa. The major changes in the stricture of the body occur at the cost of the fat stored in the body by the larva. The pupa is similar in appearance to the adult bee, having developed mouth parts, legs, wings and other appendages of the body. The adult bee emerges after cutting the cocoon and the waxen capping of the cell. Table 6 shows the time taken by the three castes of the Indian boneybee in the three stages of development.

Table 6. Duration (days) of the life cycle of different castes of honeybee

\begin{tabular}{llllccccc}
\hline Caste & \multicolumn{8}{c}{ Duration } \\
\cline { 2 - 9 } & Egg stage & Larval stage & Pupal stage & Total \\
\hline & 1 & 2 & 1 & 2 & 1 & 2 & 1 & $2 *$ \\
Queen & 3 & 3 & 5 & 5 & $7-8$ & 8 & $15-16$ & 16 \\
Worker & 3 & 3 & $4-5$ & 5 & $11-12$ & $12-13$ & $18-20$ & 21 \\
Drone & 3 & 3 & 7 & 7 & 14 & 14 & 24 & 24 \\
\hline
\end{tabular}

* 1, A. cerana indica; 2, A. mellifera

\section{Points of caste distinction}

Egg. In appearance and size the eggs of different castes are alike. They are, however, laid in the cells provided for rearing the different castes.

Larva. The larvae of all castes also look similar but the queen and drone larvae become larger than the worker larvae during the later half of their development.

Pupa. The drone and worker (or queen) pupae can be distinguished by examining the eyes. In the former the eyes meet over the head and in the latter they are apart. Further in the brood comb the worker pupae have flat capping with dull and dry appearance and drone pupae have a convex capping, with a hole in the centre in case of $A$. cerana indica.

Adult. 1. The eyes of drone meet over the head and are far apart in worker and queen.

2. The abdomen of drone is black and blunt without sting. In case of worker, the abdomen is striped, and has a barbed sting. In case of queen the abdomen may be golden brown (Apis florea) shining black ( $A$. cerana indica), or dark (A. dorsata) in colour and triangular in shape (more elongated than the worker's) and provided with sword shaped sting. In $A$. mellifera the colour varies with the race.

3. Queen's wings appear shorter than worker's because of her proportionately longer abdomen.

4. The thickness of the thorax of a worker is smaller than that of either queen or drone. In case of Apis cerana indica (hill variety-3000 feet altitude) the thickness of thorax of a worker varies from $3.3 \mathrm{~mm}$ to $3.5 \mathrm{~mm}$ and that of a queen from 4.3 to $4.5 \mathrm{~mm}$. In case of mellifera the worker bees can pass through a whole of $4.14 \mathrm{~mm}$ diameter but the queen can not. This fact is utilized in devising queen excluder. 
5. Worker bee has well developed tongue for sucking nectar, highly modified legs with pollen brushes and a pair of pollen baskets (on the hind pair of legs) and wax glands. In queen and drones neither the tongue nor the legs are so modified nor the wax glands present.

\section{REFERENCES}

Cherian, M.C. and Mahadevan, V. 1945. The longevity of Indian bee (Apis indica). Indian Bee J. $8(3 / 4): 41-43$

Kapil, R.P. 1957. The length of life and the brood rearing cycle of the Indian bee, Apis indica Fab. Arch. Bienenk. 35 (1) : 17-22.

Shah, F.A. and Shah, T.A. 1981. Egg-laying capacity of Kash mir bee, Apis cerana, Bee Wld. 62 (3) :114-15.

Sharma, P.L. 1958. Brood rearing activity of Apis indica F and egg laying capacity of its queen. Indian Bee J. 20 (11): 166-73. 


\section{BEEKEEPING EQUIPMENTS}

Primitive and rustic hives like hollowed logs of wood, baskets (Fig.12, 13), clay pots and clay cavities fixed in the walls of mud houses have been in use for keeping bees in India till about the close of nineteenth century. These hives and wall hives with movable frames are still in use in some parts of the country. The hive developed on the principle of bee space by L. Langstroth revolutionized the whole concept of beekeeping from 1851 onwards. Langstroth's contribution to the ind ustry was quickly followed by the invention of comb foundation by Johannes Mehring in 1857, honey extractor by Frang von Hruschka in 1885 and many others. Beginning was made to keep bees in movable frame hives in 1880's in India which occurred after the widespread adoption of Langstroth hive in the West.

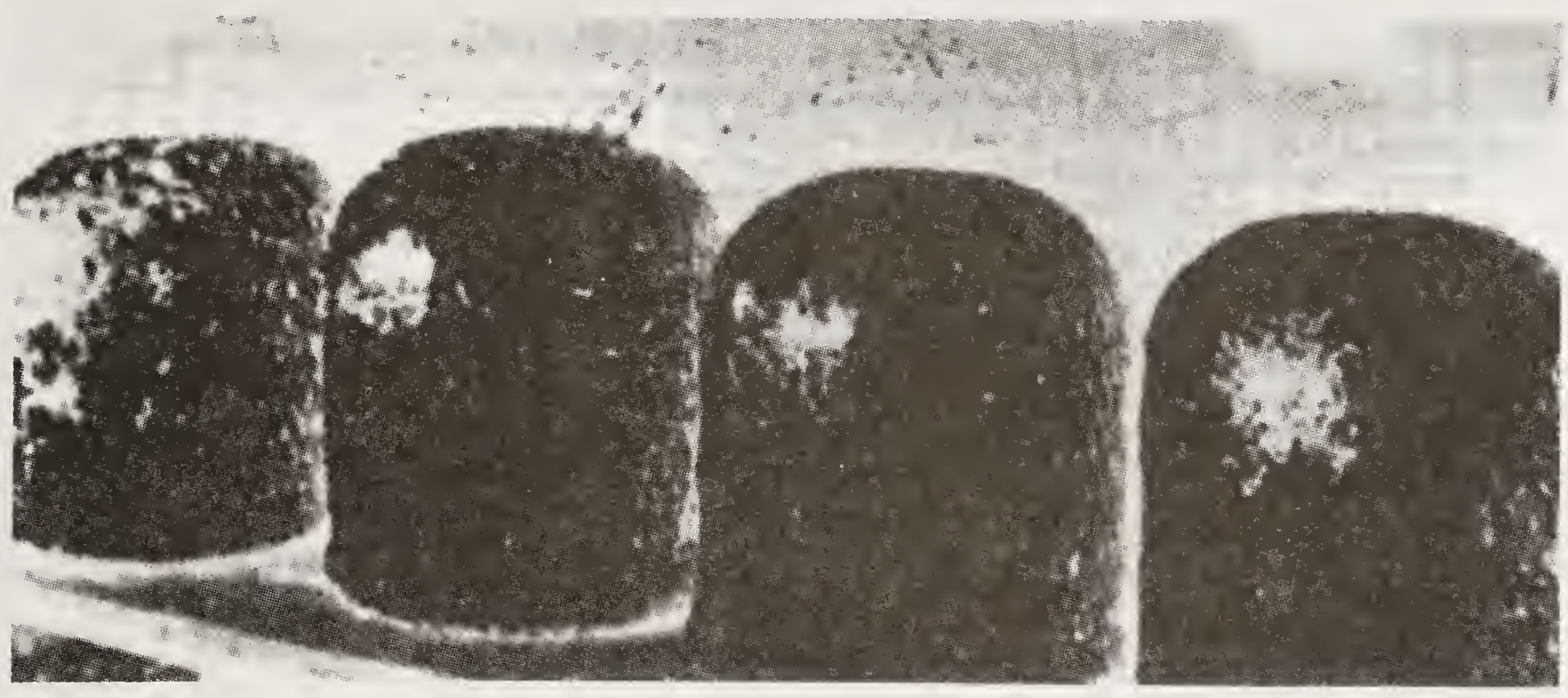

Fig. 12. Baskets still in use as bee hives.

In India Langstroth hive is in vogue for keeping Apis mellifera colonies and for Apis cerana indica colonies in Kashmir. Apis cerana indica colonies are now kept in ISI hives or Newton hives in other parts of the country. The bee space given for Apis mellifera $(9.525 \mathrm{~mm})$ by Langstroth has been modified depending upon the race of Indian bee (Tables 7 and 8).

Standard size equipment in a country or large regions of a country has several advantages. The equipment can be procured from good manufacturers and bees can be transhiped to other areas with hives, transport hives and frames. But to use a standard size equipment over la rge areas is not practicable because the type and size of hive would vary with climate, flora and species and race of honeybee. Small colonies in large hives may get their brood chilled during a sudden cold spell and their surplus combs may get attacked by wax moth. Colony must be able to build up strength to attain super chamber strength. Surplus honey can be obtained only if strength is enough 


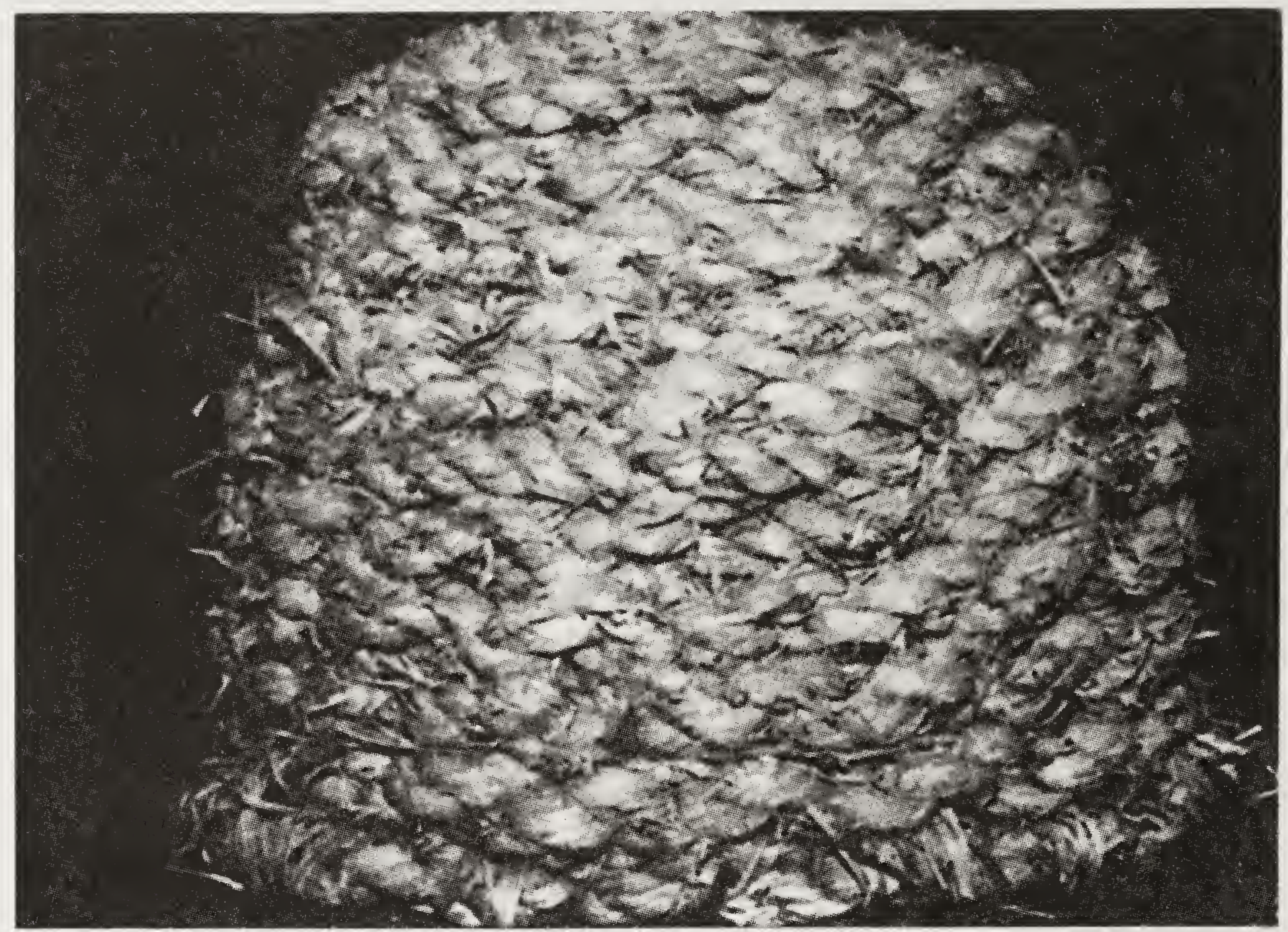

Fig. 13. Baskets still in use as bee bives.

Table 7. Dimensions of movable frames used in different hives

\begin{tabular}{llc}
\hline Name & $\begin{array}{l}\text { Dimensions of } \\
\text { brood frame }(\mathrm{mm})\end{array}$ & $\begin{array}{c}\text { Super frame } \\
(\mathrm{mm})\end{array}$ \\
\hline $\begin{array}{l}\text { British standard } \\
\text { Langstroth }\end{array}$ & $350 \times 212$ & - \\
& $440 \times 228$ & $440 \times 228$ \\
Dadant & & $440 \times 130$ \\
Dadant & $462 \times 281$ & $462 \times 156$ \\
Villager & $462 \times 156$ & $462 \times 156$ \\
Newton & $300 \times 175$ & $300 \times 175$ \\
Travancore & $206 \times 144$ & $206 \times 62$ \\
& $300 \times 150$ & $300 \times 100$ \\
\hline
\end{tabular}

to store honey in combs of super. Therefore, size of hive should be such that colonies cover the super chamber frames by the onset of main honey flow. Apis mellifera queens are very prolific and lay. large number of eggs and hence colony builds up large population but in Apis cerana indica the egg laying rate of queen is low and colony strength does not grow comparable to $A$. mellifera. Within Apis cerana indica different races differ greatly in colony strength build up. The build up of colonies also depends upon the availability of flora in a locality. Enough flora will ensure more populous colonies but in marginal areas the size of the hive frames has been reduced accordingly. Therefore, the size of the hive would differ with all these factors. However, keeping in view the many benefits of standardization of equipment any unwanted tendency to multiply the number and sizes of frames must be deprecated. 


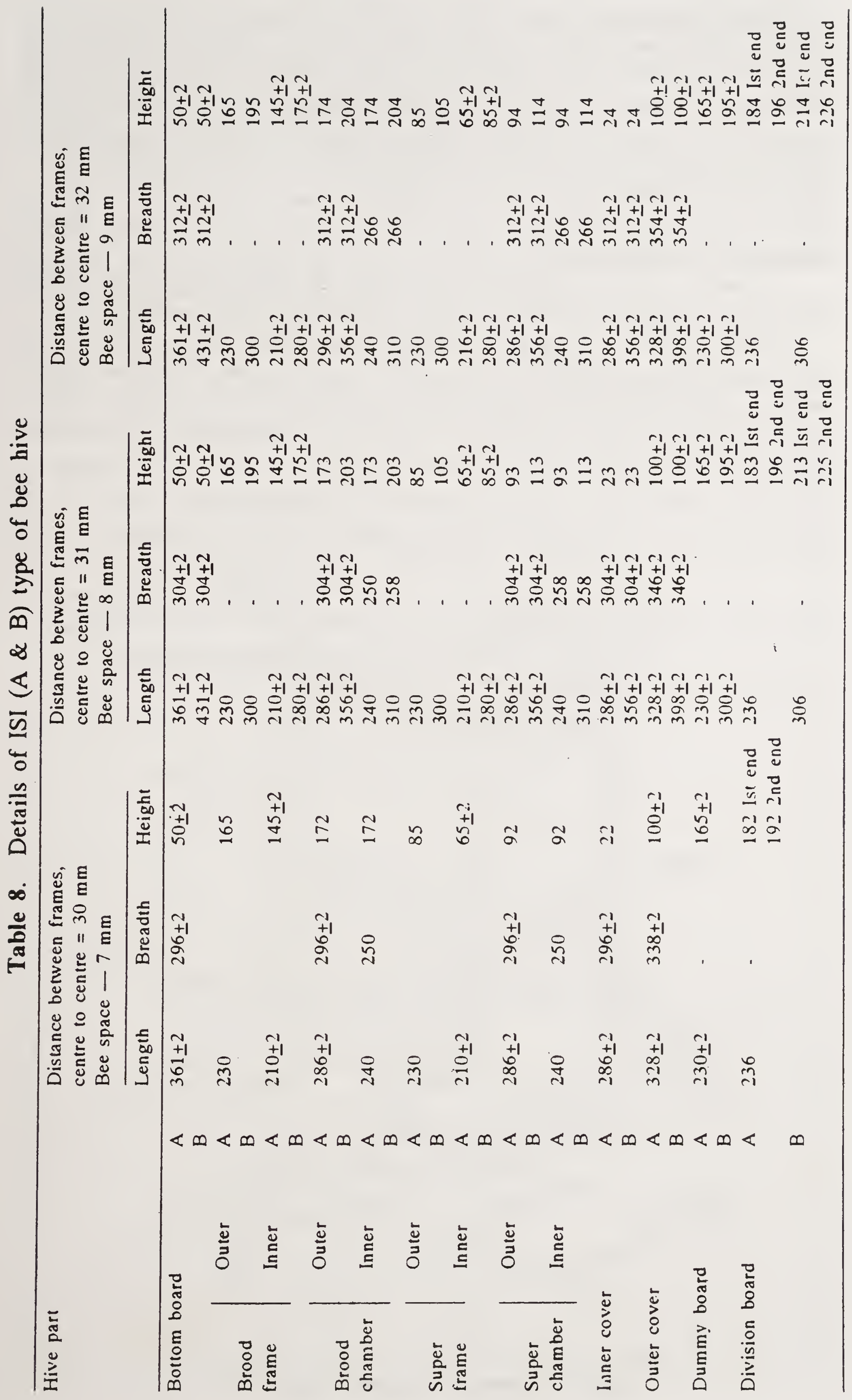


There are many types of movable frame hives being used in different parts of the world. Dimensions of movable frames of some of the important ones are given in Table 7. The Langstroth, Indian Standards Institute (ISI) and Newton frame hives are more in use than other types in India. Details for making these types are outlined below. It must be emphasized that exact specifications should be followed to avoid unnecessary annoyance and irritation during use of these hives.

\section{Langstroth ten-frame hive}

1. Stand. Any four-legged stand $15-25 \mathrm{~cm}$ high will do. Its upper dimensions should be such as to support the bottom board properly.

2. Bottom board. It can be made either by taking a piece of wood 550 $\mathrm{mm}$ long, $406 \mathrm{~mm}$ broad and $22 \mathrm{~mm}$ thick, or by joining 2 wooden boards together, nailing in position with wooden rods. Along each end of the longer side is nailed a wooden rod $550 \mathrm{~mm}$ long, $22 \mathrm{~mm}$ broad and $22 \mathrm{~mm}$ thick

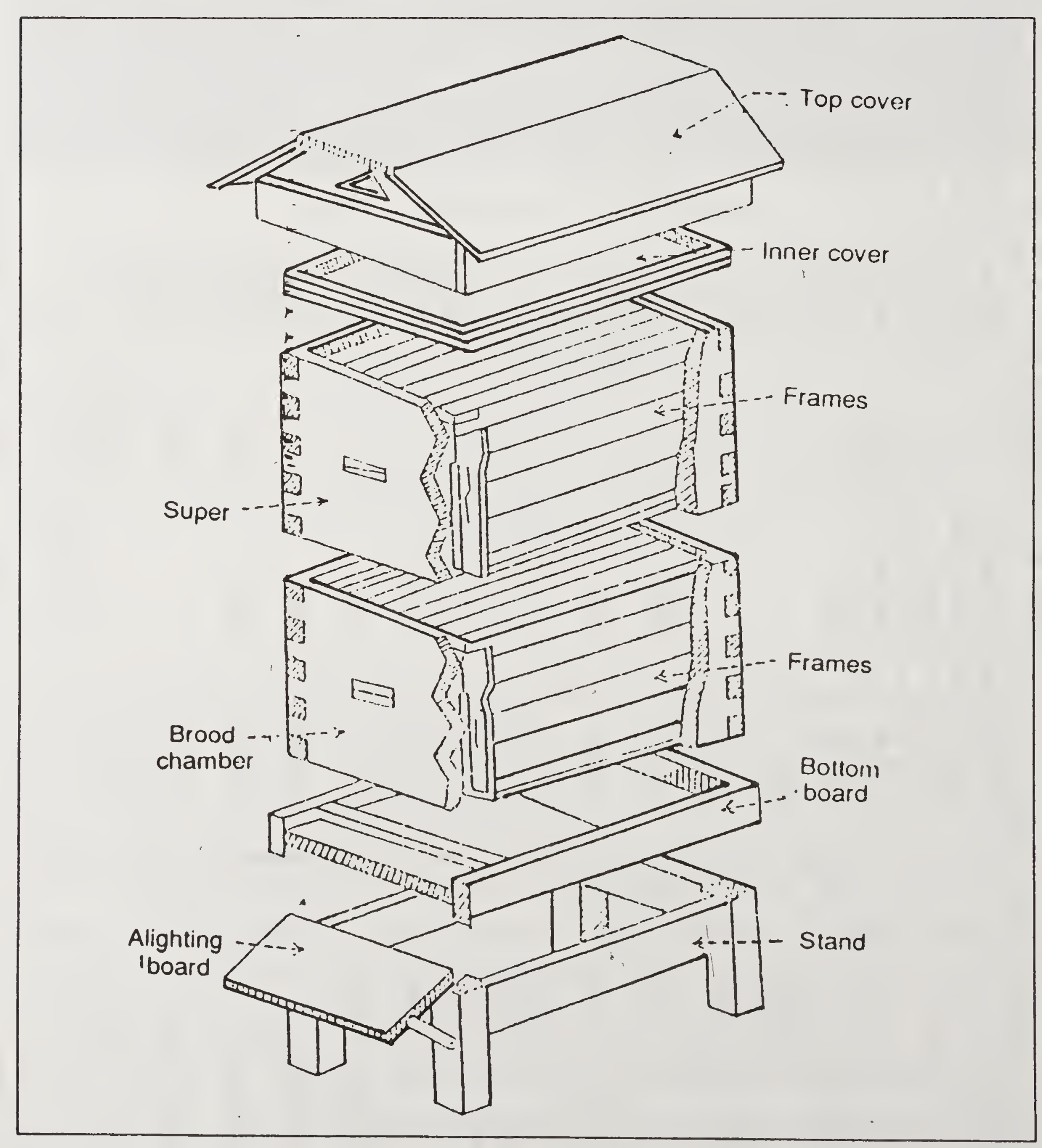

Fig. 14. A two-storey Langstroth ten-frame hive. 
and another wooden rod $363 \mathrm{~mm} \times 22 \mathrm{~mm}$ is nailed at the back. The front is provided with entrance rod which is $363 \mathrm{~mm} \times 22 \mathrm{~mm} \times 22 \mathrm{~mm}$ and this has an entrance $75 \mathrm{~mm}$ long and $22 \mathrm{~mm}$ deep in its middle. Two wooden blocks, to be used for shortening the entrance, when necessary, should also be prepared, each block being $75 \mathrm{~mm} \times 38 \mathrm{~mm} \times 22 \mathrm{~mm}$.

3. Brood chamber. It is a rectangular box without top and bottom and is made of $22 \mathrm{~mm}$ thick wood. Its length on the outside is $500 \mathrm{~mm}$ and on the inside $456 \mathrm{~mm}$, its breadth on the outside is $406 \mathrm{~mm}$ and on the inside $363 \mathrm{~mm}$ and its height is $238 \mathrm{~mm}$. A rabbet $16 \mathrm{~mm}$ deep and $13 \mathrm{~mm}$ wide is cut along the entire length of its width planks.

4. Frame. Consists of top bar, two side bars and a bottom bar.

Dimensions for self spacing frame (Fig.15).

(i) Top bar: $475 \mathrm{~mm}$ long, $25 \mathrm{~mm}$ wide and $22 \mathrm{~mm}$ thick. It is cut to $9 \mathrm{~mm}$ thickness on both sides for a length of $25 \mathrm{~mm}$. It has a groove in the middle of its lower side for fixing the comb foundation sheet.

(ii) Side bar: Each is made of $9 \mathrm{~mm}$ thick wood and is $226 \mathrm{~mm}$ long. The upper part of each is $34 \mathrm{~mm}$ wide and lower part $25 \mathrm{~mm}$ wide. Each is cut out from the middle portion at either end to accommodate the top and the bottom bars, respectively. There are 4 holes in each side bar for wiring the frame.

(iii) Bottom bar: $440 \mathrm{~mm}$ long, $19 \mathrm{~mm}$ wide and $9 \mathrm{~mm}$ thick. The outside measurements of the frame are $440 \mathrm{~mm} \times 228 \mathrm{~mm}$.

Two $15 \mathrm{~mm}$ staples should be driven in (to leave only $9 \mathrm{~mm}$ outside) to

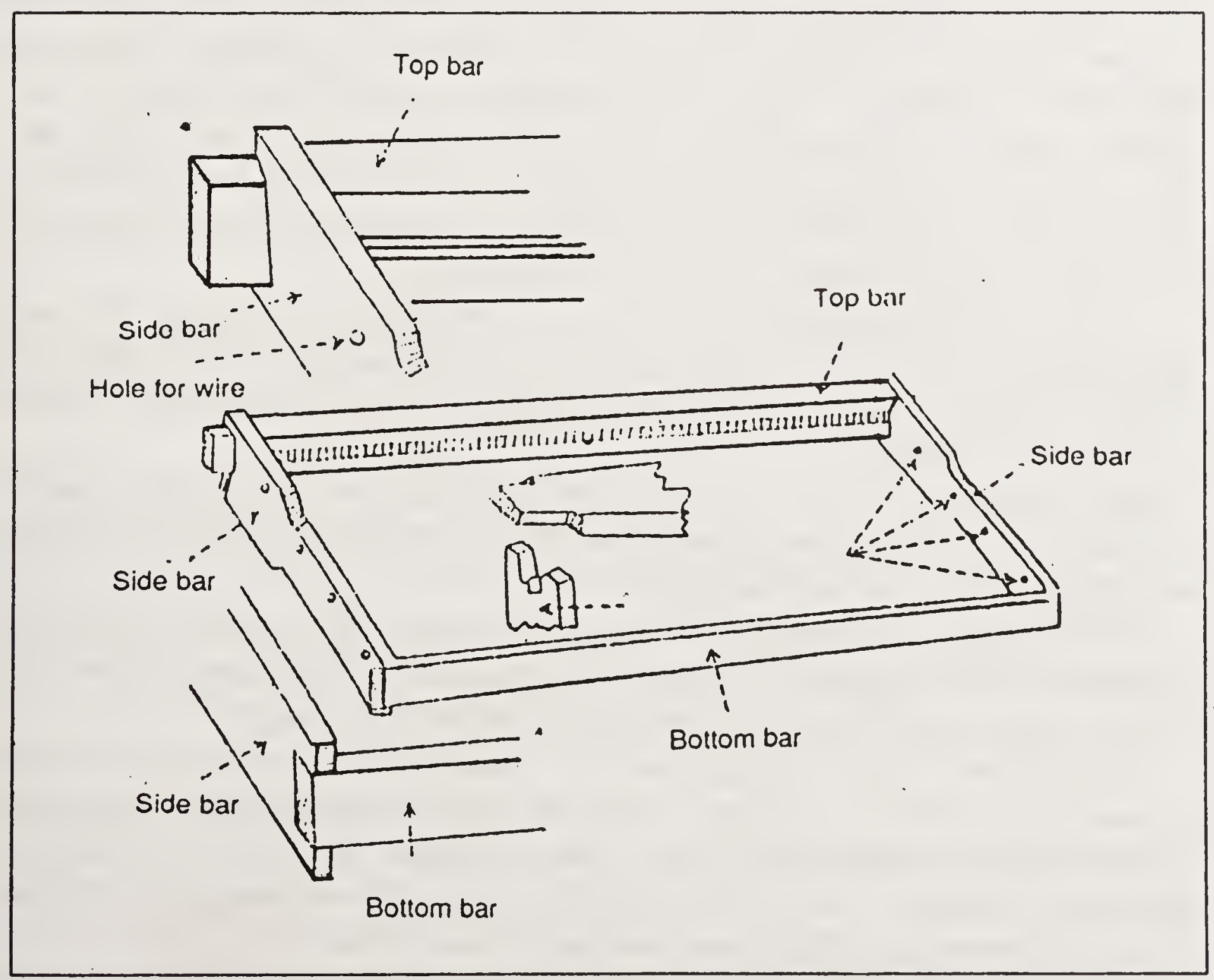

Fig. 15. Details of the Hoffman frame. 
top bar on its opposite side so that the frames stand $34 \mathrm{~mm}$ apart. One should make all frames either Hoffman or staple-spaced type. Tinned wire of 28 gauge should be used in wiring the frame.

5. Super. The dimensions of the super and the super frames should be the same as those of the brood chamber and the brood chamber frames respectively.

6. Inner cover. This is wooden board to cover the brood chamber or the super as the case may be. It is $500 \mathrm{~mm}$ long, $406 \mathrm{~mm}$ broad and $9 \mathrm{~mm}$ thick wood. It has $9 \mathrm{~mm}$ thick and $22 \mathrm{~mm}$ wide wooden bar nailed on to each of its four sides.

7. Top cover. It is made up of $9 \mathrm{~mm}$ thick wooden board nailed to a rectangular frame $50 \mathrm{~mm}$ high, all covered over with a metallic sheet so as to make it impervious to rain water. Its inside measurements are $525 \mathrm{~mm} \times$ $425 \mathrm{~mm}$. It rests loosely over the hive.

\section{Newton hive}

Newton hive has the following parts (Fig.16):

1. Stand. A log of wood of about $10 \mathrm{~cm}$ in diameter and well soaked in solignum is burried deep in the ground. A length of about 20 to $30 \mathrm{~cm}$ is left above ground and a board $40 \times 30 \mathrm{~cm}$ is fixed on its top with long nails and screws. The hive is placed on this platform on the log.

2. Bottom board. It is a plank slightly wider and $25 \mathrm{~mm}$ longer than the brood chamber with beadings on three sides into which the hive-body fits in tightly. The extension of the front serves as the alighting board.

3. Brood chamber. It is a box without top and bottom and is made of $22 \mathrm{~mm}$ thick planks with outer dimensions $278 \mathrm{~mm} \times 256 \mathrm{~mm} \times 160 \mathrm{~mm}$ and inner $234 \mathrm{~mm} \times 225 \mathrm{~mm} \times 160 \mathrm{~mm}$. Alorig the top of the front and rear planks a groove of $6 \mathrm{~mm}$ depth and $9 \mathrm{~mm}$ width is made for resting the frames and a clearance of about $6 \mathrm{~mm}$ is provided between the lower extremity of the frames and the bottom board. The front plank has an opening $88 \mathrm{~mm}$ $\times 9 \mathrm{~mm}$ at its lower side to serve as an entrance.

4. Brood frame. Self spacing (i) top bar breadth $22 \mathrm{~mm}$, length $250 \mathrm{~mm}$ and thickness $3 \mathrm{~mm}$, (ii) side bar height $144 \mathrm{~mm}$, width at top $28 \mathrm{~mm}$ and width at bottom $12 \mathrm{~mm}$, and (iii) inner length of frame $206 \mathrm{~mm}$, inner height of frame $144 \mathrm{~mm}$.

An extension of $3 \mathrm{~mm}$ is given on either side of the side bar and a clearance of $6 \mathrm{~mm}$ is effected when two frames are kept side by side. There are 7 frames in a brood chamber.

5. Super and super frame. It has the same length and breadth as the brood chamber, but its height is $78 \mathrm{~mm}$. The dimensions of the super frame are those of the brood frame but the internal height is $62 \mathrm{~mm}$.

6. Top cover. It has sloping planks on either side. An opening of $87 \mathrm{~mm}$ square, fitted with wire gauge is made on the low ceiling plank to provide ventilation. Two holes in the front and rear planks of the top provide the necessary draught. Care should be taken to provide a clearance of about $6 \mathrm{~mm}$ between the ceiling plank and the frames below.

For the manufacture of hives, light, well seasoned, good quality timber 


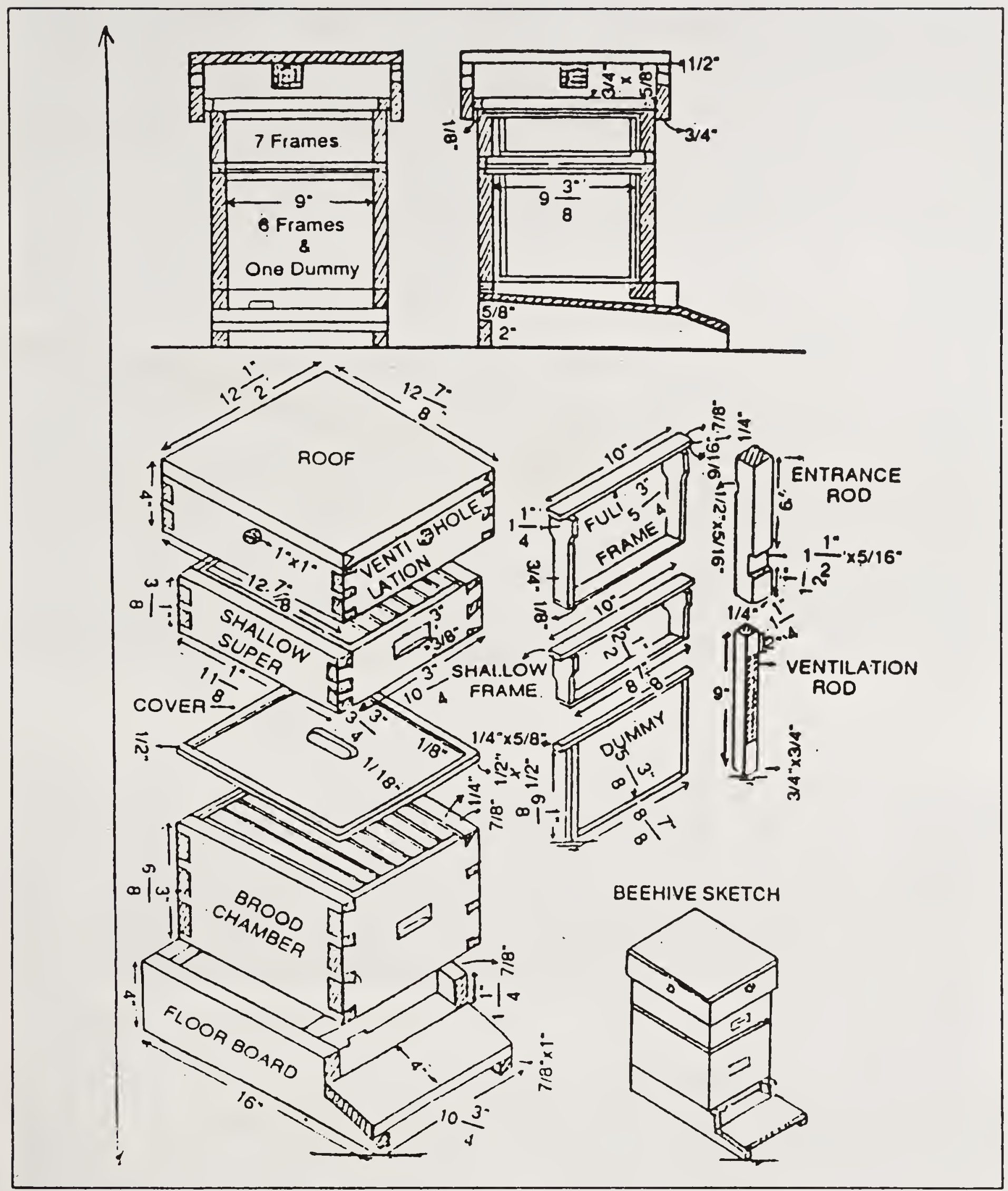

Fig. 16. Details of a Newton hive with super.

should be used. The wood should not have a strong smell. Kail (Pinus excelsa), teak (Tectona grandis) and toon (Toona ciliata) a re some of the woods suitable for the purpose. The hives should be preferably painted white or aluminium on the outside to protect the timber 4 from weathering agencies. The hive parts should be accurately cut so that they may be inter-changeable throughout the apiary and as emphasized earlier, in the particular part of the country.

\section{Other beekeeping equipments}

Comb foundation. In nature bees build new combs from beeswax produced by them and make parallel combs which are attached to the ceiling of the cavity or box. The combs may be built in the direction of the entrance, at right angles to it or in an oblique fashion. In the movable frame hive it is 
imperative that straight combs be built in the frames so that when shifted from hive to hive they may maintain the correct bee space between them. This may be done by fixing sheets of beeswax, on which the bases of worker brood cells are embossed (Fig.17) in the frames. They are reinforced by fixing horizontal wires in the frames and embedding the same into comb foundation on a wire embedding board by means of a wire-embedder.

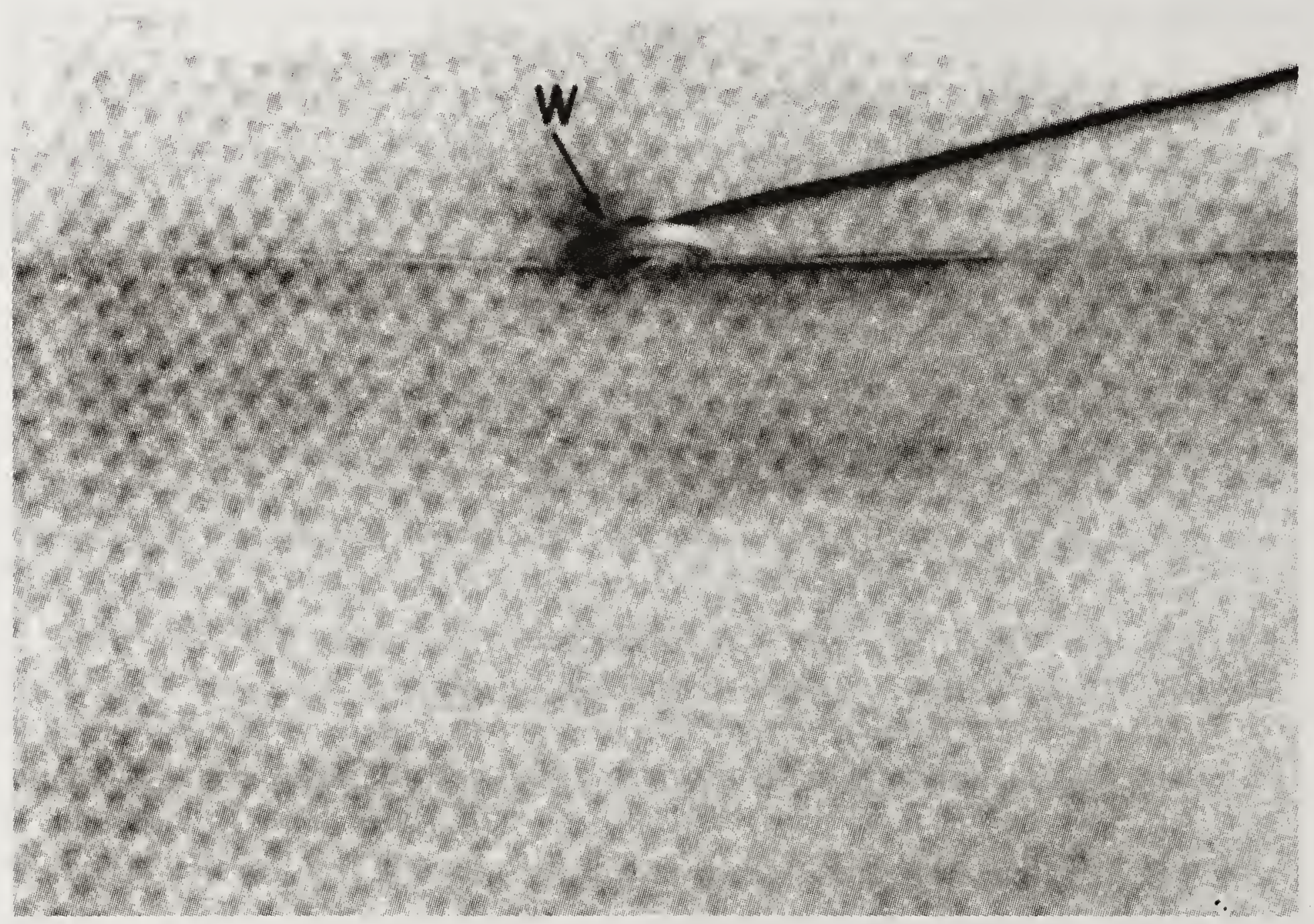

Fig. 17. Wax comb foundation fixed to wires of frame with the help of wire embedder.

As Apis cerana indica bees build cells of various sizes in combs in different parts of the country and therefore, the use of several types of comb foundation mills (Fig.18) are required. Number of cells would vary between 20 to 24 per $100 \mathrm{~mm}$ for $A$. cerana indica in India and for Apis mellifera this number is about 19. Therefore, the size of cells required should be specified while placing an order.

The combs built on comb foundation are strong and sturdy. Brood combs and combs with honey after extraction can be reused. As stated above, the repeated use of such combs helps one to produce more money as the bees do not have to build new combs. Besides, in building combs on comb foundation, bees have to add the cell walls only. Brood comb cells get narrowed down by continuous use and it is wise to destroy them for rendering wax after 3-4 years of use and get new combs raised.

Queen excluder. To obtain pure honey free from extraneous matter it is necessary to separate the brood nest from the surplus honey stores. This is done with the help of queen excluders, which are perforated sheets (Fig.19) of zinc or round wires assembled together $3.75 \mathrm{~mm}$ apart for $A$. cerana 


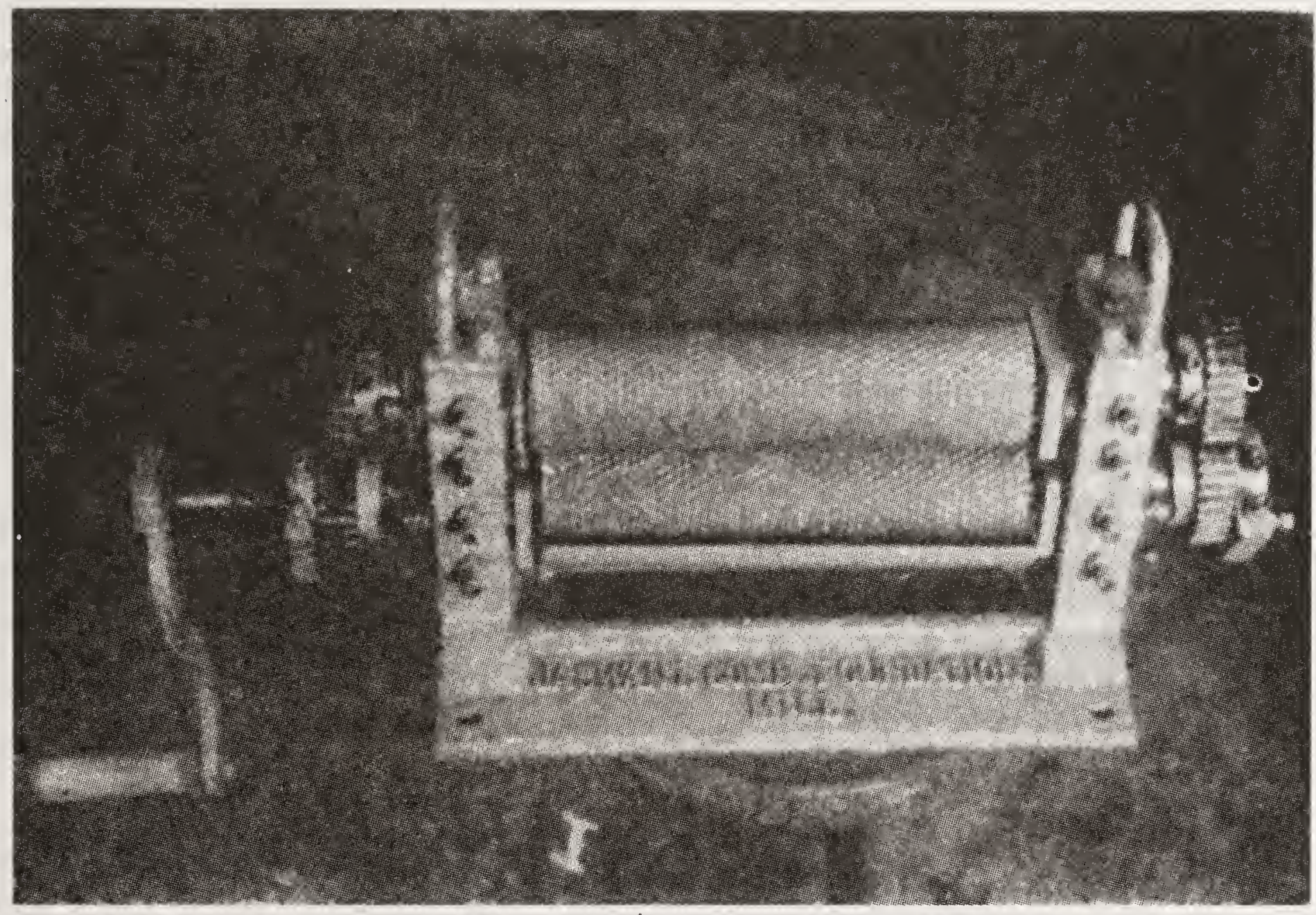

Fig. 18. Hand-operated comb foundation mill.

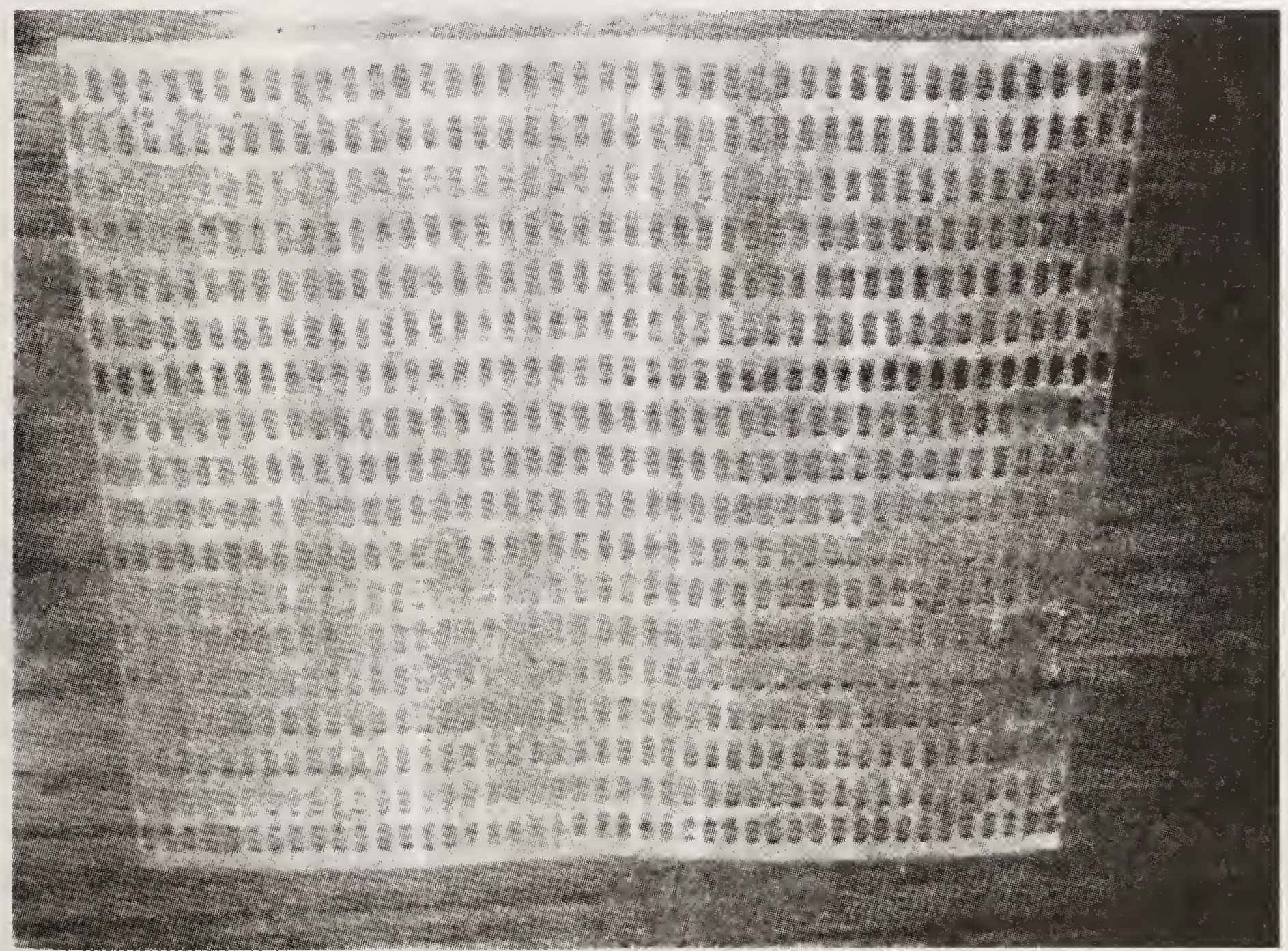

Fig. 19. Queen excluder.

indica. The workers with their thorax varying from $3.33 \mathrm{~mm}$ to $3.50 \mathrm{~mm}$ can pass through these perforations but not the queens with their thorax varying from $4.40 \mathrm{~mm}$ to $4.50 \mathrm{~mm}$. For $A$. mellifera the diameter of the perforation in the sheet or space between the wires is $4.20 \mathrm{~mm}$. Since the queen bee is 


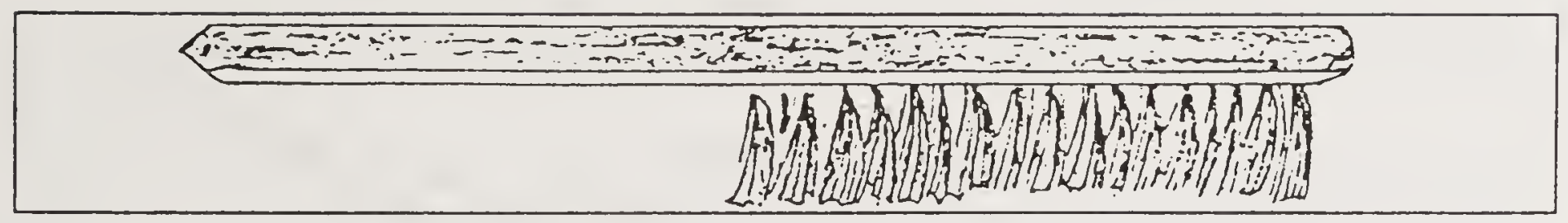

Fig. 22. Soft-hair bee brush.

Swarm-catching equipment. Generally swarms settle on limbs of nearby trees. If they cluster on a thin branch, it can be gently cut above the swarm by a scateur and taken to the hive. If the swarm has settled on a thick limb it has to be approached and the swarm collected in a swarm-catching basket by gently. directing the bees into it. Sometimes the bees are shaken into a box which is held on the underside of the limb or caught in a swarmcatching bag (Fig.23) from an inaccessible limb. Swarms can be helped in settling down early by sprinkling water into the hovering swarm with the help of a syringe.

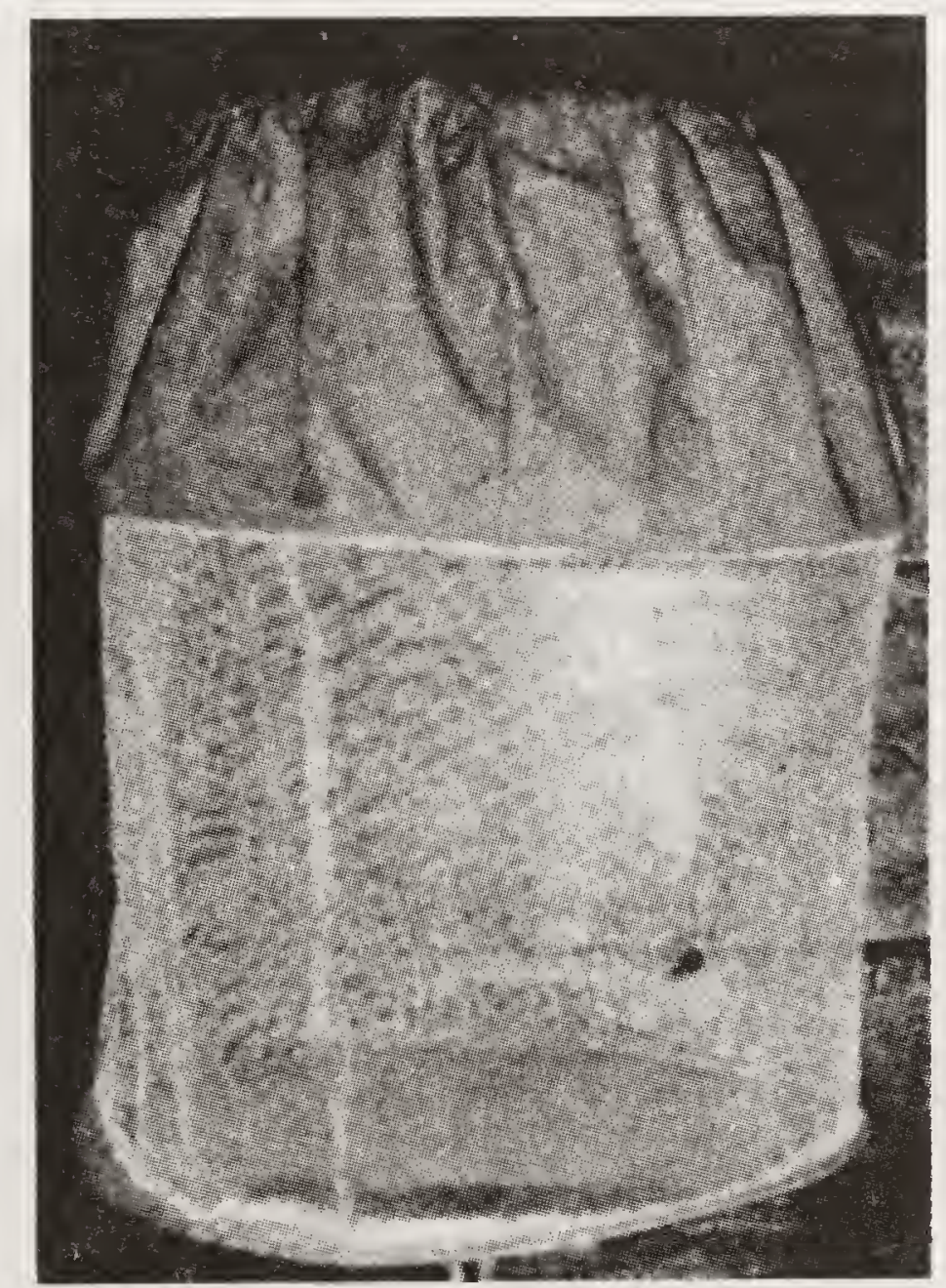

Fig. 23. Swarm-catching bag.

Feeders. Various kinds of feeders for feeding sugar syrup to bees are used by beekeepers. The division board feeder (Fig.24), a wooden trough of the regular frame dimensions with shoulders so made that it may hang in the hive just like any other frame and with a wooden strip to serve as a float, is a useful appliance. A lever-lid tin (empty tin) with holes in the lid are also good types of feeders.

Queen cages. Various types of queen cages are in use. The miller queen introducing cage, the Smith introducing cage, the queen mailing cage and the wire gauge cages are some of the types often used (Fig.25). 


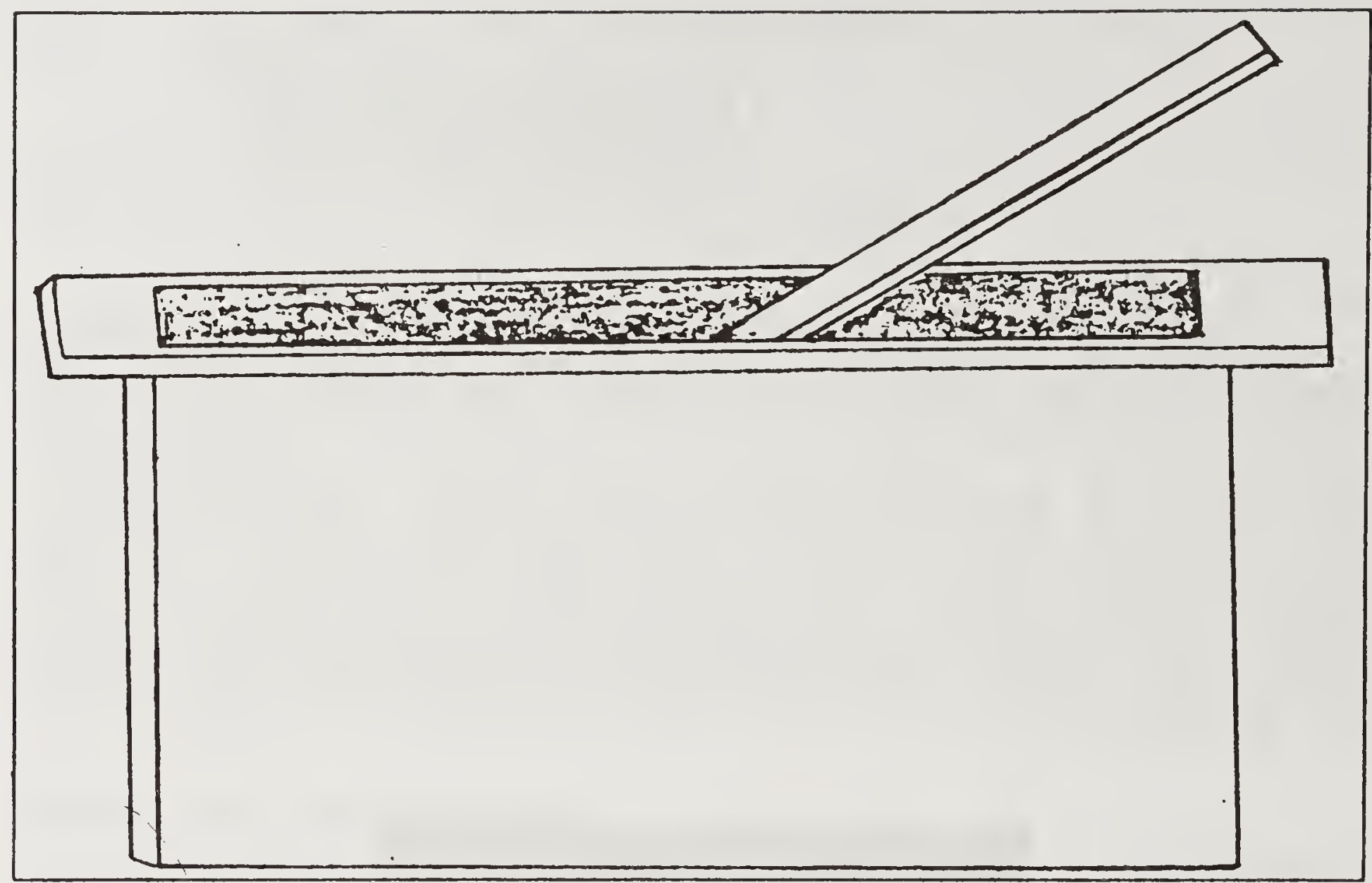

Fig. 24. Division board feeder.

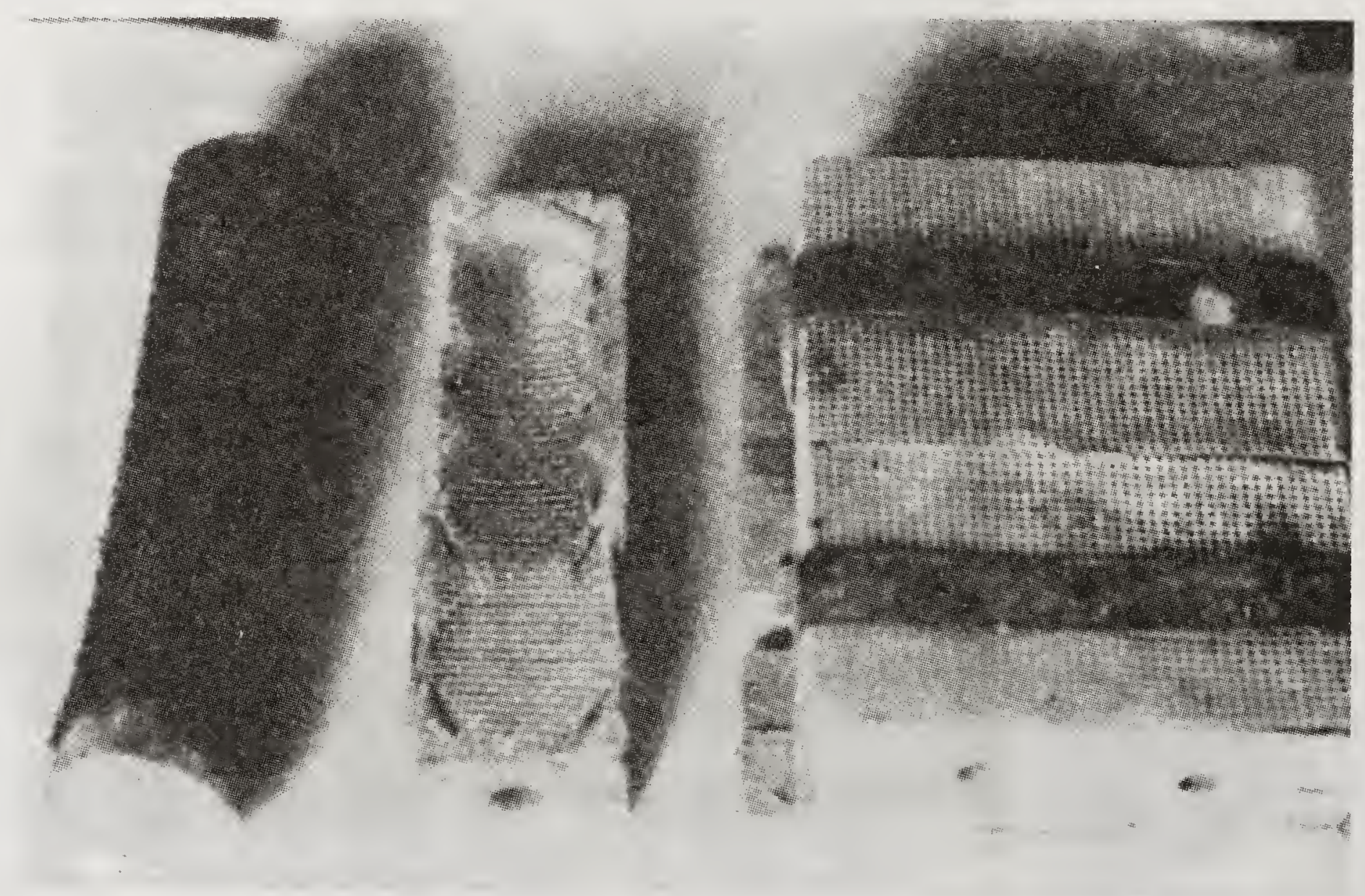

Fig. 25. Different types of queen cages.

Queen cell protector. A queen cell which may have to be introduced from a queen right to a queenless colony, is often protected in a queen cell protector until its acceptance by the bees.'

Dummy or division board. It is a wooden partition which serves as a movable wall and helps to reduce the size of the brood chamber so that bees can keep the hive air-conditioned and well protected from bee-enemies or inclement weather. 
Bee escape. It is a device for allowing the bees to go through a selfclosing exit.

(i) Wire guage cone. It has a broad and a narrow end. The broad end is nailed to a board, etc. and the narrow end, which is wide enough to let the bees pass out but not large enough to attract their attention for re-entry, serves as the exit.

(ii) Spring bee escape. A pair of delicate strings is so fixed as to allow the bees to push through and make an exit. The springs close the opening by sprining back to their original position.

Often a double bee escape is used in boards which are used for clearing honey supers of bees in them. The boards are placed between the honey supers and brood chambers. 


\section{SOCIAL BEHAVIOUR OF BEES AND RELATED MANAGEMENT PRACTICES}

HONEYBEE colony is composed of different castes and number of workers in a colony is very large but a colony acts as a single unit. All the individuals are highly organized. Each worker bee follows a sequence of activities and this depends upon its age. With age certain changes in structure take place and it is known that behaviour and activities depend upon these changes. In other words a bee behaves and performs the activity which she is capable of doing. Besides physiological development of worker bee, behaviour is also believed to be genetically controlled because activities are not the result of learning. Even stimuli like sound, chemicals and mechanical, influence bee behaviour.

\section{Division of labour}

All the three forms, i.e. queen, drones and workers perform specific functions in the bive. Queen bas the sole responsibility of laying eggs. Drones mate and fertilize the queen. All other duties in a hive are the responsibility of workers and they make the colony a successful social unit. All the duties are not performed by a worker bee alternatively at the same time but these activities are correlated with age of worker bees, though flexibility in age specific division of labour does exist.

Young bees for 2-3 weeks after emergence stay inside the hive. For the first 2-3 days worker bees clean cells from which the bees have emerged. These bees do the cleaning job because they are not capable of doing other duties in the hive.

Nursing. Within 2-3 days worker bees take up nursing duties. For the first 3 days of this phase, they feed the older larvae. Hypopharyngeal and mandibular glands of these bees are not yet fully developed and hence they do not nurse younger larvae up to 3 days of age which are exclusively fed on glandular secretions. Larvae after 3 days of hatching receive glandular secretions mixed with pollen and honey and thus it is less nutritive as compared to young larval food. The food glands are fully developed and active when the worker bee is 6-13 days old. These workers nurse the larvae of up to 3 days of age. Nurse bees supply excess food to young larvae and larvae float on the food, but the rate of food supply is reduced after 3 days of larval age, which is only progressive. Young larval food is rich in proteins but older larvae get food which is poorer in proteins but has more sugars. Nurse bees make brief visits to the cells from the time the egg is laid. Duration of the visits is variable. During third week of worker bee life the activities are of very varied nature. Bees whose food glands have exhausted and become inactive after 13 days shift to other jobs in the hive. These bees are prospective 
foragers so they undertake orientation flights to acquaint themsclves with vicinity. These orientation flights (also known as play flights) occur in the early afternoons. The duration and scope of the play Rights increases every day. These hive bees also take up the duty of packing pollen in cells and ripening nectar. They receive a nectar load from ficld bec and drop of honey is brought out and taken in by depressing and extending the proboscis. By doing so several times the moisture content is reduced and unripe honey is now deposited in the honey cell for further ripening by fanning.

Comb building. Worker bees between the agc of 14 and 18 days have active wax.glands which are present in the sterni of last four abdominal segments. Wax producers take a sip of honey and hang in festoons at the site wherc wax is needed. About 8.4 units of honey are consumed to screte one unit of wax. Pollen as protein source is necessary for wax producers. These bees can secrete wax for sometime at the expense of body stores but they cannot continuc for longer period, if pollen is not available. Wax appears in the sternal segments, where wax glands are present, in the form of scales. These scales are removed by basitarsi of meso-and meta-legs. These scales arc brought forward and manipulated by mandibles and forclegs. Mandibular gland secretion is mixed while manipulating and kncading. The addition of glandular secretion facilitates the attachment of masticated wax scale at the sitc of comb building (Fig. 26).

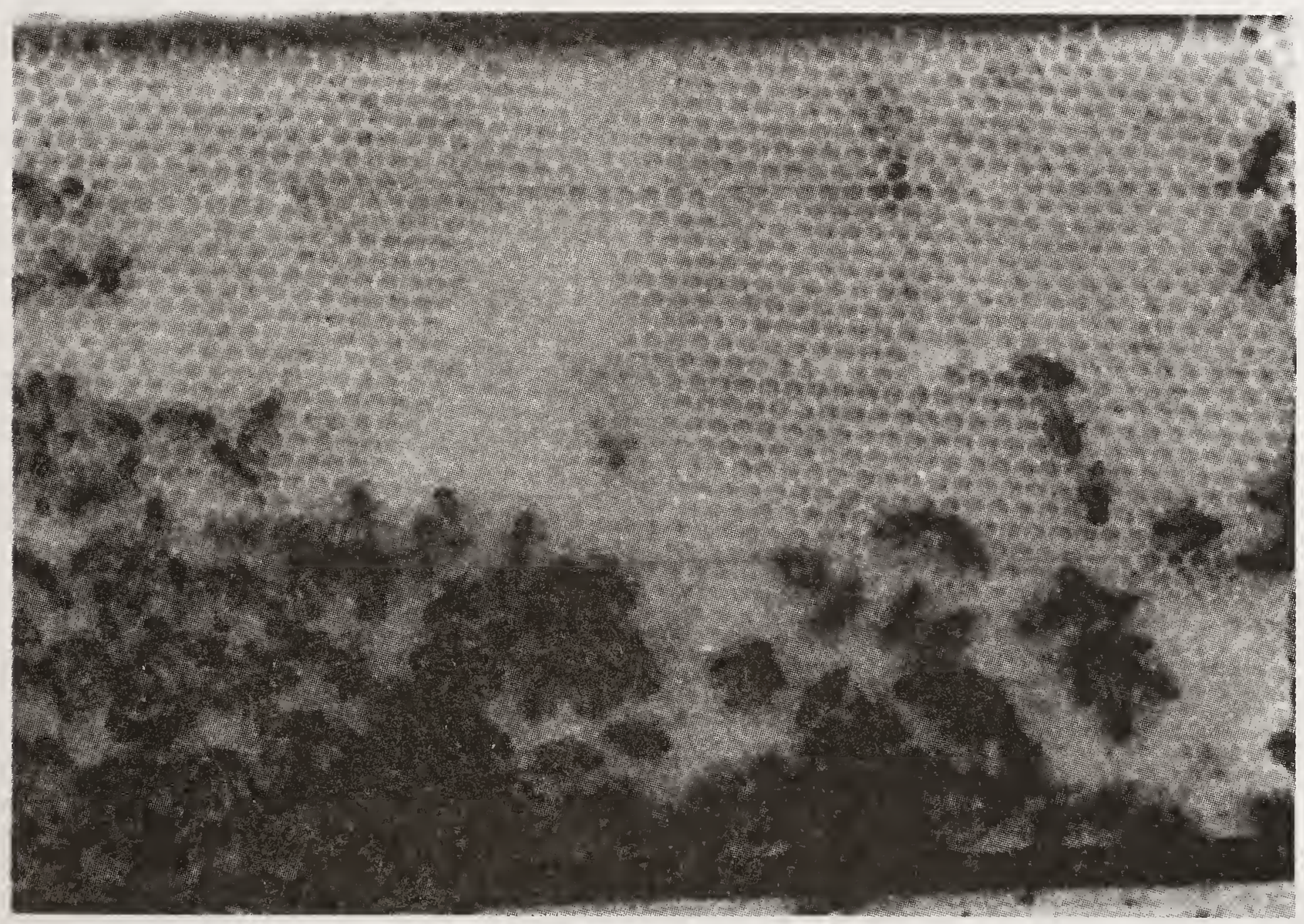

Fig. 26. Comb raising on foundation sheet.

Guarding and defence. Some bees, when 18 days old become guards. Number of guard bees necded is very low during honey flow period but number of becs guarding the entrance is more during dearth period. During 
active flow period strangers can enter into hive without examination. During dearth period guard bees are very attentive and thoroughly examine the ingoing bees. If foreign bee tries to gain access to the hive then there can be a fight. In this fight the strangers and sometimes the guard bees may be killed. Guard bees adopt a frightening posture at the entrance (Fig.27). They stand on middle and hind legs with front portion slightly raised, antennae are held forward with closed mandibles. When guard bees are excited, they open the mandibles with half spread wings. Guard bees turn around to examine all incoming bees near them. In India, the Indian honeybee shows a definite defensive behaviour against predatory wasps (Singh, 1972) and this defensive behaviour could be induced. Atwal and Dhaliwal (1969) reported that hill strain of $A$. cerana indica were more irritable than yellow Californian race of A. mellifera. Dhaliwal and Atwal (1969) placed groups of Apis species in cages and showed that aggressiveness was in the order of $A$. mellifer $a>A$. dorsata $>A$. cerana indica $>A$. florea. From the studies, the authors inferred that $A$. mellifera, when introduced into a territory of other species would probably extend its range and exploit the flora better than other species could do, provided climatic conditions are favourable.

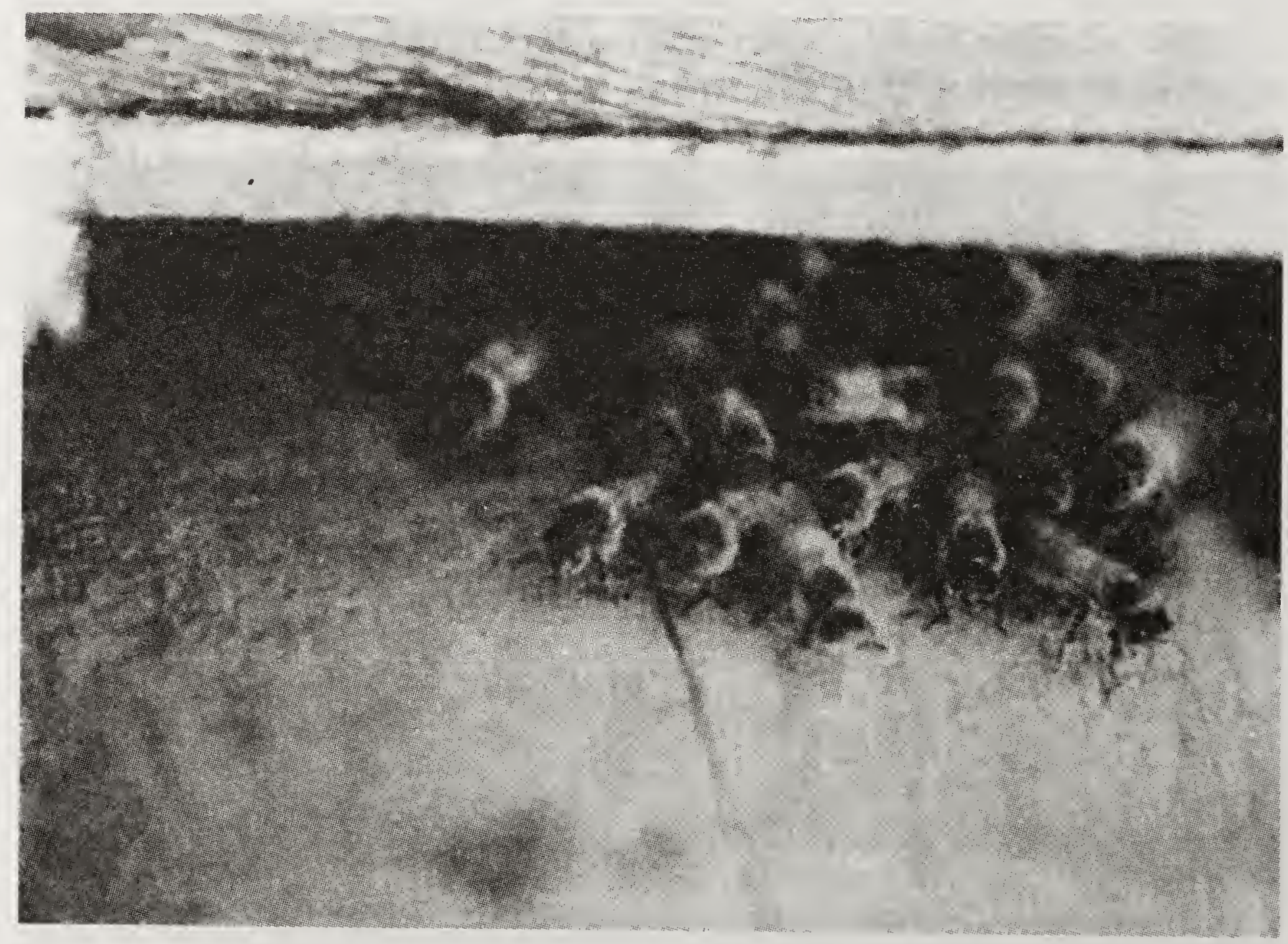

Fig.: 27. Alert guard bees defending the colony.

\section{Food gathering and artificial feeding}

Food is essential in hive for the colony to function as a social unit. Bees after 3 weeks of age become field bees. They may start foraging trips even at an early age but make a few foraging trips. Nectar, pollen, water and propolis are required in a hive. It is commonly accepted that foragers can shift from one kind of raw material gathering activity to the collection of 
other and this is determined by the needs in the nest. There is also an opposite belief that a bee continues to gather nectar or pollen only for whole of her field duties. But shift from pollen to nectar gathering appears to be more common.

Nectar gathering and storing. Forager bees survey the vicinity for the presence of nectar plants or she may be guided by other dancing bees in the hive. Odour is an important cue for the bees in finding the source. Once the source has been found, the forager collects the load. She cannotdifferentiate the flower which has nectar than from one which does not have nectar. She learns it only by inserting her proboscis (Figs. 28 and 29). A. mellifera can carry a large nectar load up to $80 \mathrm{mg}$ but average size of load is $40 \mathrm{mg}$. In case of $A$. cerana indica the average load is $20 \mathrm{mg}$ size of load is $40 \mathrm{mg}$. In case of $A$. cerana indica the average load is $20 \mathrm{mg}$. Size of nectar loads in 2 species has been determined by Gupta et al. (1984); A. cerana indica and A. mellifera foraging on Plectranthus rugosus carried a load of 18 and $27 \mu \mathrm{l}$, respectively to the hive. A: cerana indica carry a load equal to $64 \%$ of their body weight as compared to $82 \%$ in $A$. mellifera (Singh, 1971). A load is collected from number of flowers; as it is difficult to follow a forager for whole of the foraging trip, the exact data on this aspect has not accumulated. However, $A$. cerana indica and $A$. mellifera bees have been reported to visit 288 and 358 flowers respectively to collect a nectar load from Plectranthus rogosus (Gupta et al., 1984). Worker bee presses the flabellum of her proboscis in the nectar column and the nectar rises up by capillary action in the food canal. This nectar is further pumped up to the extended crop, that is honey stomach, with the help of sucking pump formed by the parts of cibarium and pharynx.

Sugar concentration of nectar varies from as low as $7 \%$ to as high as $80 \%$.

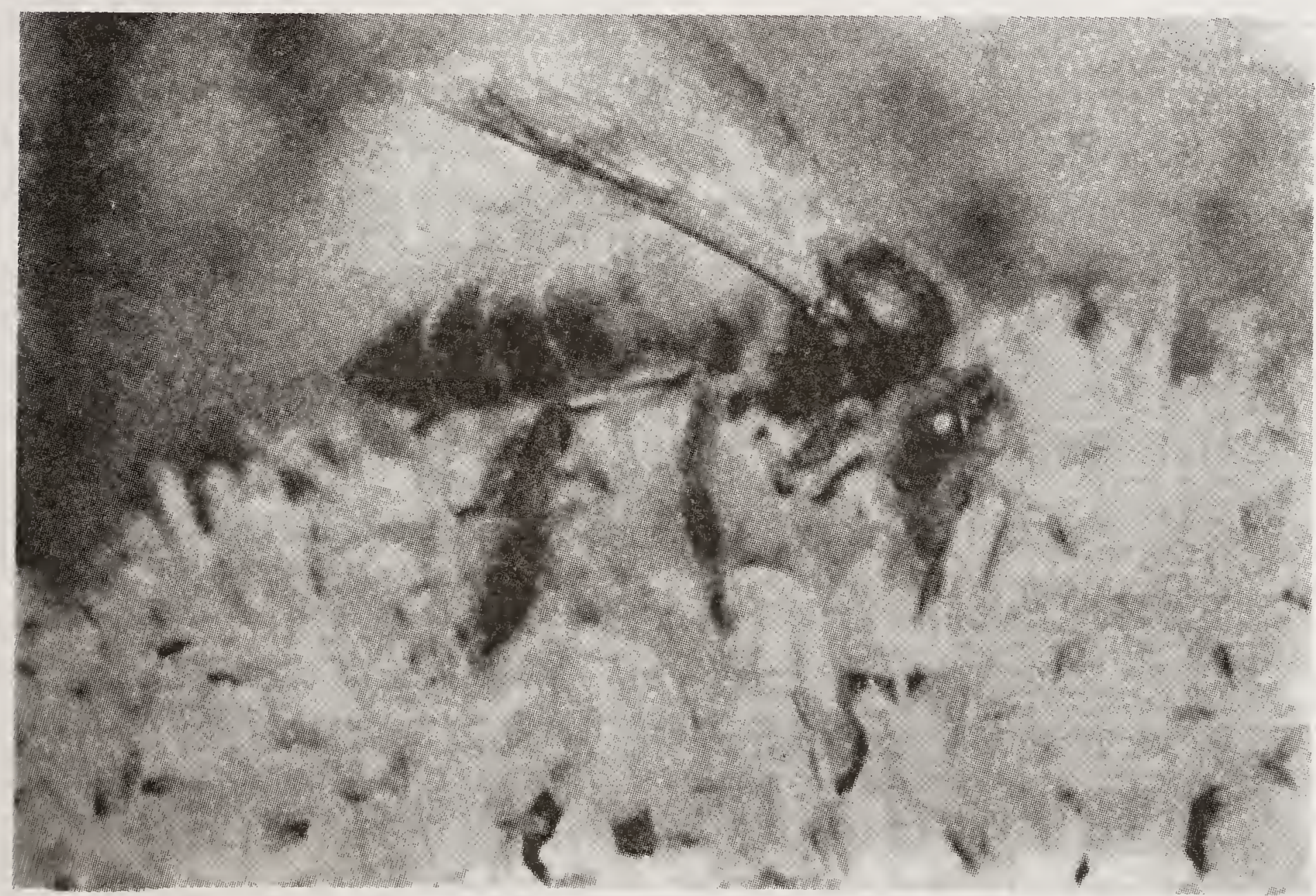

Fig. 28. Forager bee (Apis dorsata) collecting nectar from onion flower. 


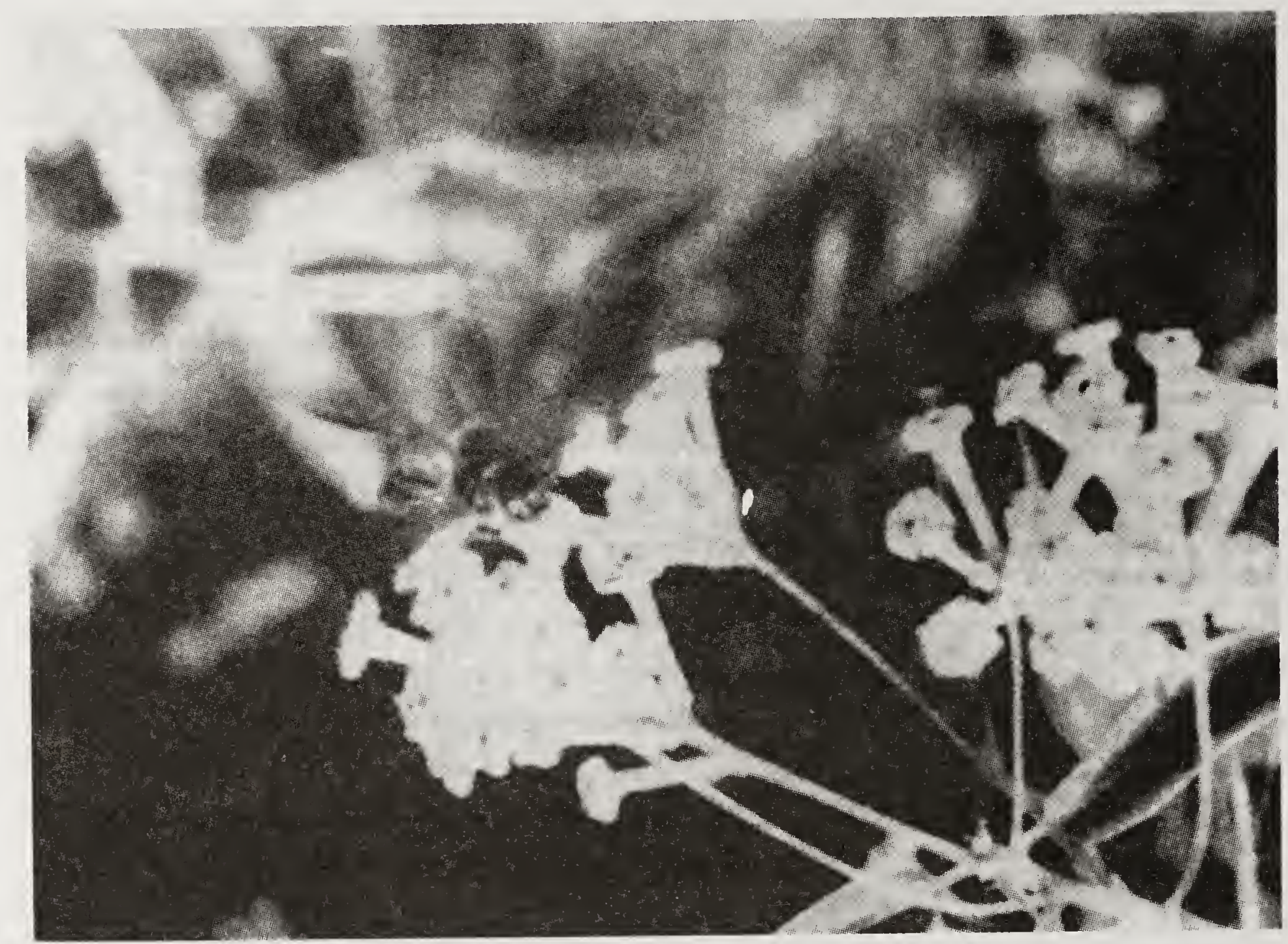

Fig. 29. Long-tongued bees (Apis dorsata) can avail flowers with long corolla tubes.

There is also little information on whether the forager reduces the water content of nectar during foraging. Some studies suggest (Gupta et al., 1984) that there is little reduction in moisture contents of nectar during this period. After returning to the hive the nectar load is transferred to the hive-bees (Fig. 30). The hive-bee brings out the nectar drop slowly on the upper side of the proboscis and mandible by alternately depressing and protracting the proboscis. In this process the water content of nectar is reduced. This unripe boney is deposited on the side wall of the comb cell when the sugar concentration is $40-60 \%$. Further evaporation of water takes place in the hive by fanning and manipulating by the bees. The rate of ripening depends on many factors like ventilation, air temperature, relative humidity and colony strength. The ripe honey when left with $16-24 \%$ moisture is sealed.

During the process of nectar collection and ripening 2 changes occur. The water is eliminated and complex sugars are converted into glucose and fructose by enzymatic action. The invertase is continuously acting from the time nectar is siphoned by the forager and till it is ripe and sealed. Some convertion is known to continue even after sealing because enzyme is added during ripening process.

Feeding nectar substitute to bees. Efficient management of bee colonies requires the beekeeper to provide artificial food to bees when they need it. In temperate climates bees are confined to the hives for few months during severe winter. Even during severe hot summer in tropical and sub-tropical regions the dearth period is prolonged. But in sub-tropical areas of India the bees have surplus nectar flows and in between the flows some subsistence 


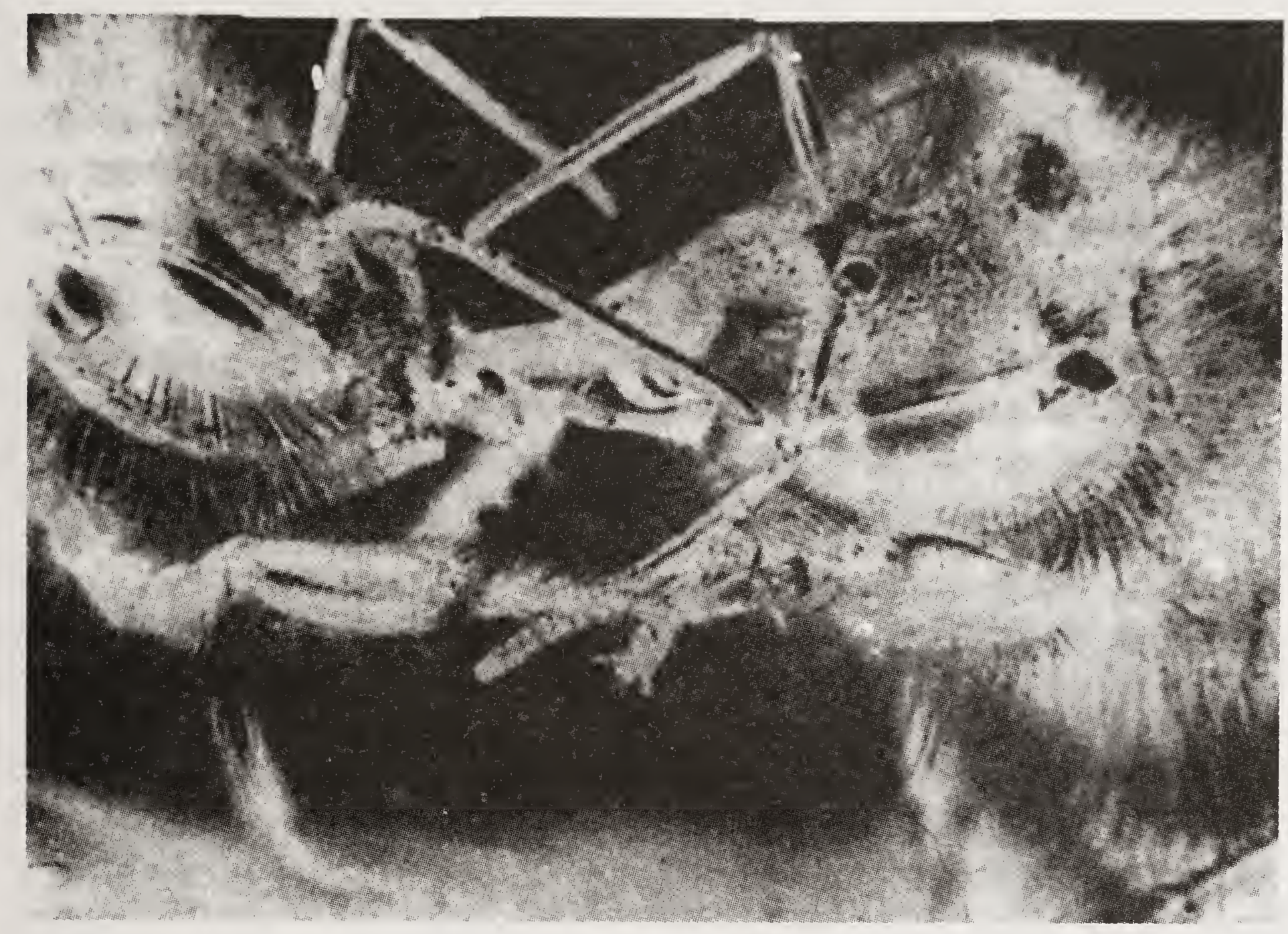

Fig. 30. Transterring of nectar load to hive bee.

flora is available and bees are not confined to the hive except during continuous rains. Far less artificial feeding is needed in such areas as compared to temperate regions. A wise beckeeper always goes for judicious feeding and for cach a piary the requirements and timing for judicious feeding would vary. By the supplementary feeding, the colonics get raw material to strengthen their stores. A colony may be short of reserves because of poor thow, stripping colonies of all the honey during harvest or when the colonies are used for pollination for longer periods. In case of supplementary feeding the food is more concentrated.

Stimulative feeding is a normal practice with the beekeepers. The stimulative feeding is provided about 3 weeks before the start of build up flow. The stimulative feeding enhance brood rearing and the colonies start with advantage in the beginning of the season. Such colonies grow in strength and put forth large foraging force to avail the surplus flow. This feeding also boosts the morales of the colony and the foragers become more active. Stimulative feeding is given to make the colony to rear more brood, therefore food of lower concentration is fed.

Manipulative feeding is required during manipulations of a colony. For hiving a swarm, some food reserves are needed for the swarm to start with. While uniting the colonies, the operation becomes easy and uniting is quick if the colony is fed artificially. Queen rearing colonies need continuous feeding.

Sugar syrup is normally provided as artificial food. Honey can also be used but it is costlier and honey feeding may also transmit diseases. Sugar is dissolved in water by heating but care should be taken-that there is tho 
scorching. Food should invariably be given indoors. All the colonics in an apiary are fed at a time but special care is essential when few weak colonics are to be fed. Food is given only in the evening when the day's activity has ceased. Sugar syrup can be provided in containers or frame feeders with floats so as to avoid drowning of bees. Sugar syrup can be filled in combs if few colonies in an apiary are to be fed.

Pollen. Pollen grains are produced in the anthers of flowers. Pollen grains are live and are male germ cells of the plant. They are released at the dehiscence of anthers which may be released throughout the day in some plants or only at a particular time of the day in others. In most flowers the dehiscence takes place just after the opening of flower. The pollen can be sticky or dry, the dry pollen is blown off soon after dehiscence but sticky pollen remains with the anther to be collected by insect foragers. Therefore, the dry pollen as in maize is available to bees for short duration of the day but sticky pollen of onion is collected by bees for longer hours of the day.

Structure and composition of pollen. Pollen grain is covered by 2 protective coats. The inner intine layer is semi-permeable but the outer thicker exine has apertures, pores or furrows on the surface. The surface of pollen grain can be smooth, granular, striate, pitted or with projections. The surface pattern and shape help in the identification of pollen grains. The size of the pollen grains vary from less than $20 \mu \mathrm{m}$ to more than $100 \mu \mathrm{m}$. The size is important because the collection of large-sized pollen grains as in okra are usually avoided by bees. Number of apertures vary from none to many. Pollen grain shape and structure are unique in some plant species but in others such as Pyrus and Prunus are much alike in different species and these cannot be differentiated in mixed samples.

Composition of pollen varies greatly with species but pollen is mainly a source of protein to bees. It contains up to $25 \%$ of proteins. Sucrose, glucose, fructose and complex sugars, though present in pollen but more sugars are added by bees while collecting and bee-collected pollen has higher amount of sugars. Vitamins, fats, oils, pigments and resins account for 1 to $14 \%$ of dry mass. Pollen is also rich source of minerals such as phosphorus, potassium magnesium, calcium and iron.

Utility of pollen to bees. Pollen is an essential component of diet of larvae and adult bees. Food glands of young nurse bees develop and become active at the expense of pollen consumption. The proteins in food glands are later transferred to other body parts when the bees shift from nursing duty. Worker bees also need to feed pollen for wax secretion and thus the comb building is maximum: during sufficient pollen availability. Worker bees fed on pollen live longer than those given no pqllen. Adult drones also feed on pollens mixed with honey. Isolated queens live longer when given pollen than those given only carbohydrates. Amount of brood rearing is largely determined by the pollen availability. The protein contents of young bees vary and are about 13 and $15 \%$ but this depends upon the quantity available to nurse bees. 
Collecting and storing pollen. Foraging bees scribble the anthers with her tongue and mandibles. Saliva and some nectar is added while doing so and the pollen becomes moist. The pollen grains released by the anthers stick to anterior body parts. Worker bees just need to walk over the anthers if the pollen is loose and dry. The pollen sticking to head, antennae and thora $x$ is brushed and passed on to pollen baskets in the metalegs. This is done by the bee while flying in between the visits to flowers. Forelegs brush the pollen grains from head portion and antennae and front portion of the thorax. Mesolegs receive the pollen from forelegs and also collect it from thorax portion and middle legs are passed through pollen comb of meta (hind) legs. The pollen in the rake is pressed by auricle into pollen basket (Fig.31)

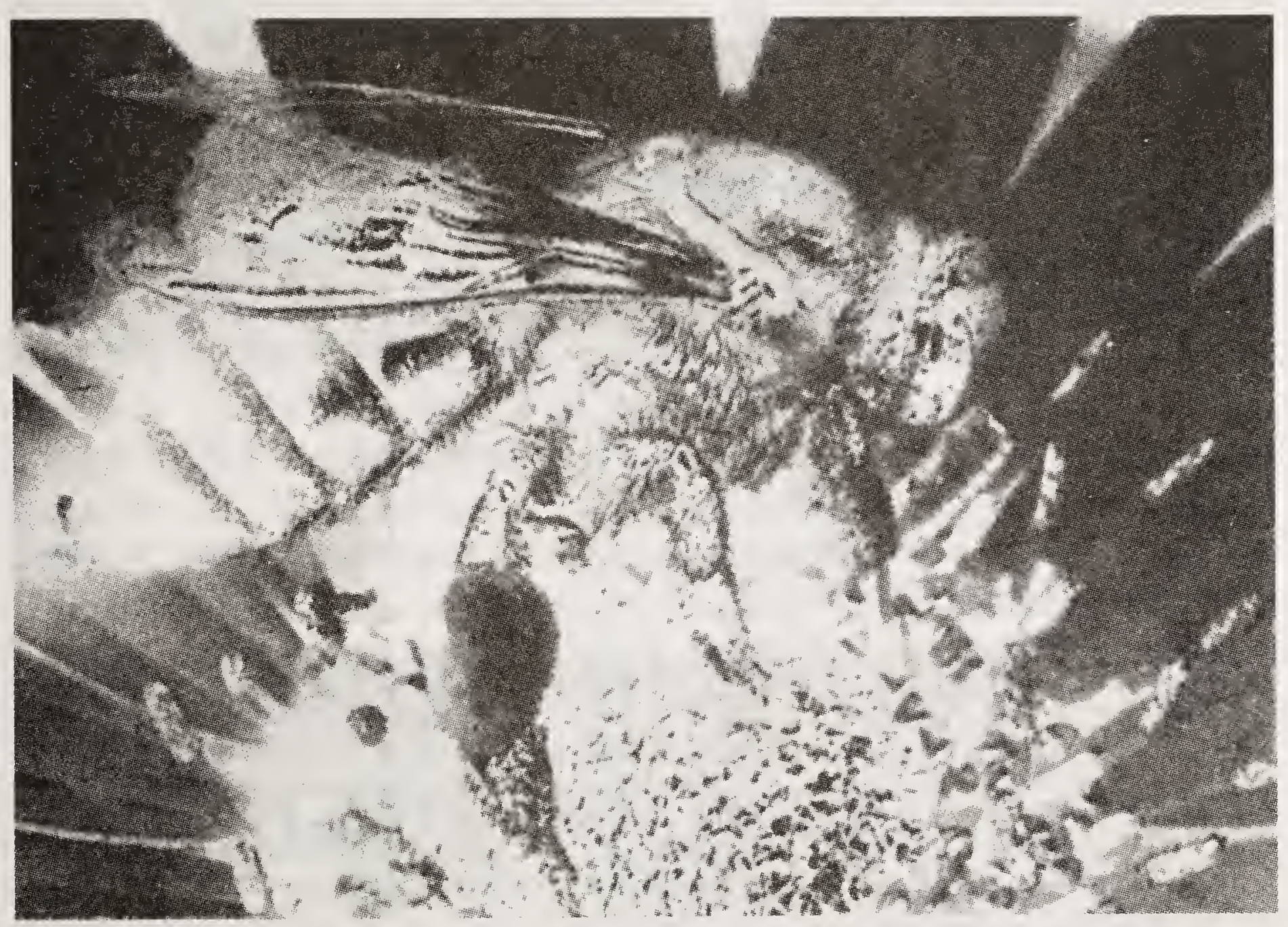

Fig. 31. A pollen forager gathering a load in her meta leg.

After returning to hive, the pollen loads are stored in cells near brood area. She examines the cells by putting her head and finds out the suitable one for storing the pollen. The loaded bee grasps the comb cell wall with her forelegs and abdomen rests on opposite wall of the cell. Middle and hind legs are put into the cell and middle legs remove the loads from hind legs. The pollen loads so unloaded are not attended by the forager but a house bee comes and packs the load into bee bread by mixing more of nectar or honey (Fig.32).

Artificial pollen food. In most localities there is shortage of pollen during one or the other part of the year. The pollen dearth causes stoppage or reduction of brood rearing by a colony. The longevity of adult bee is also affected. These effects cause decline in colony strength and it becomes essential for the beekeeper to provide pollen substitute or supplement to bees 


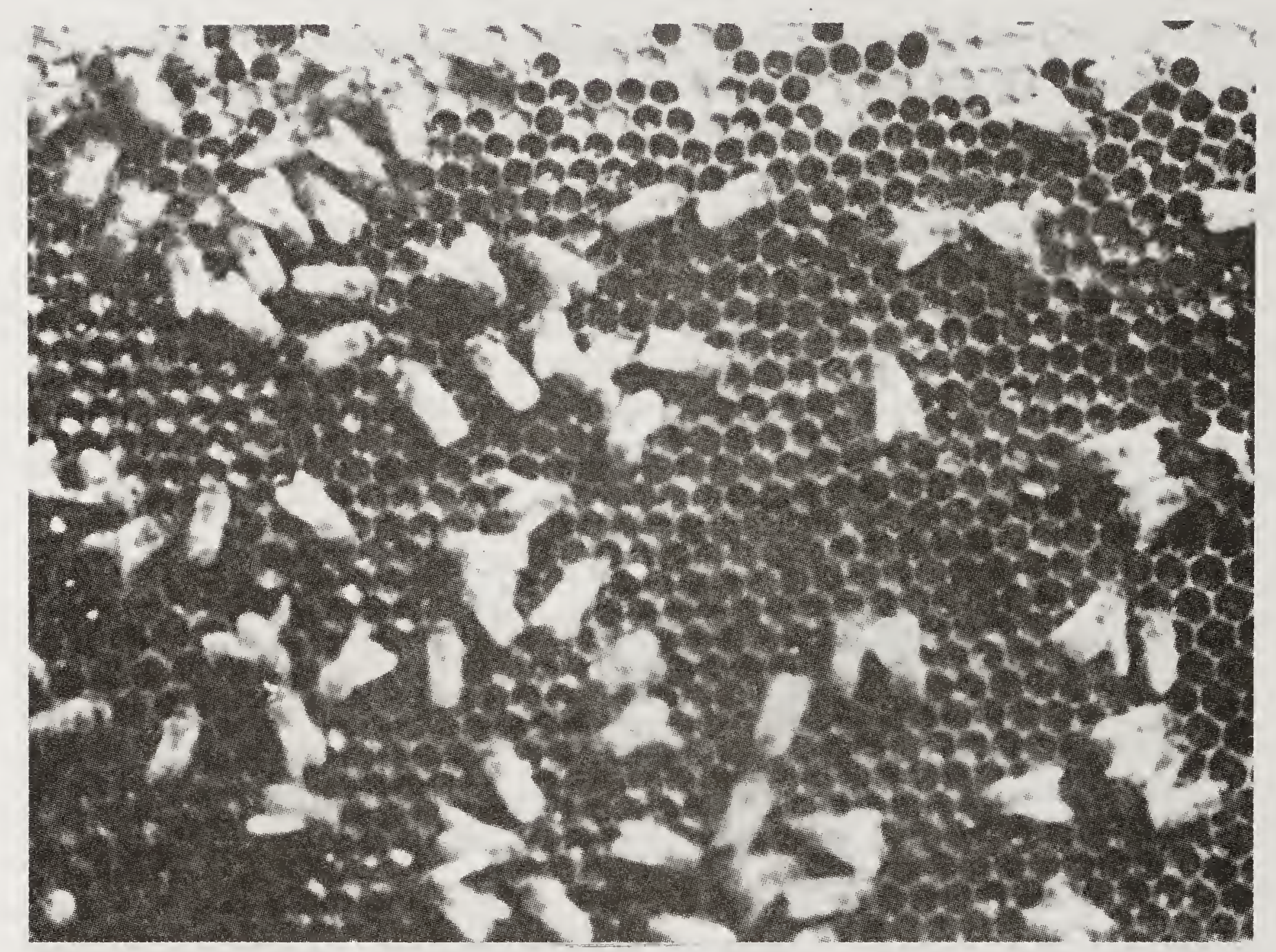

Fig. 32. Comb full of pollen stored in the form of bee bread.

(Fig.33). Natural pollen is available in many countries to prepare pollen supplements but in India this important aspect has never been realised and pollen substitute or supplement feeding is not a common practice. These mixtures are not commercially available in India. Feeding these to

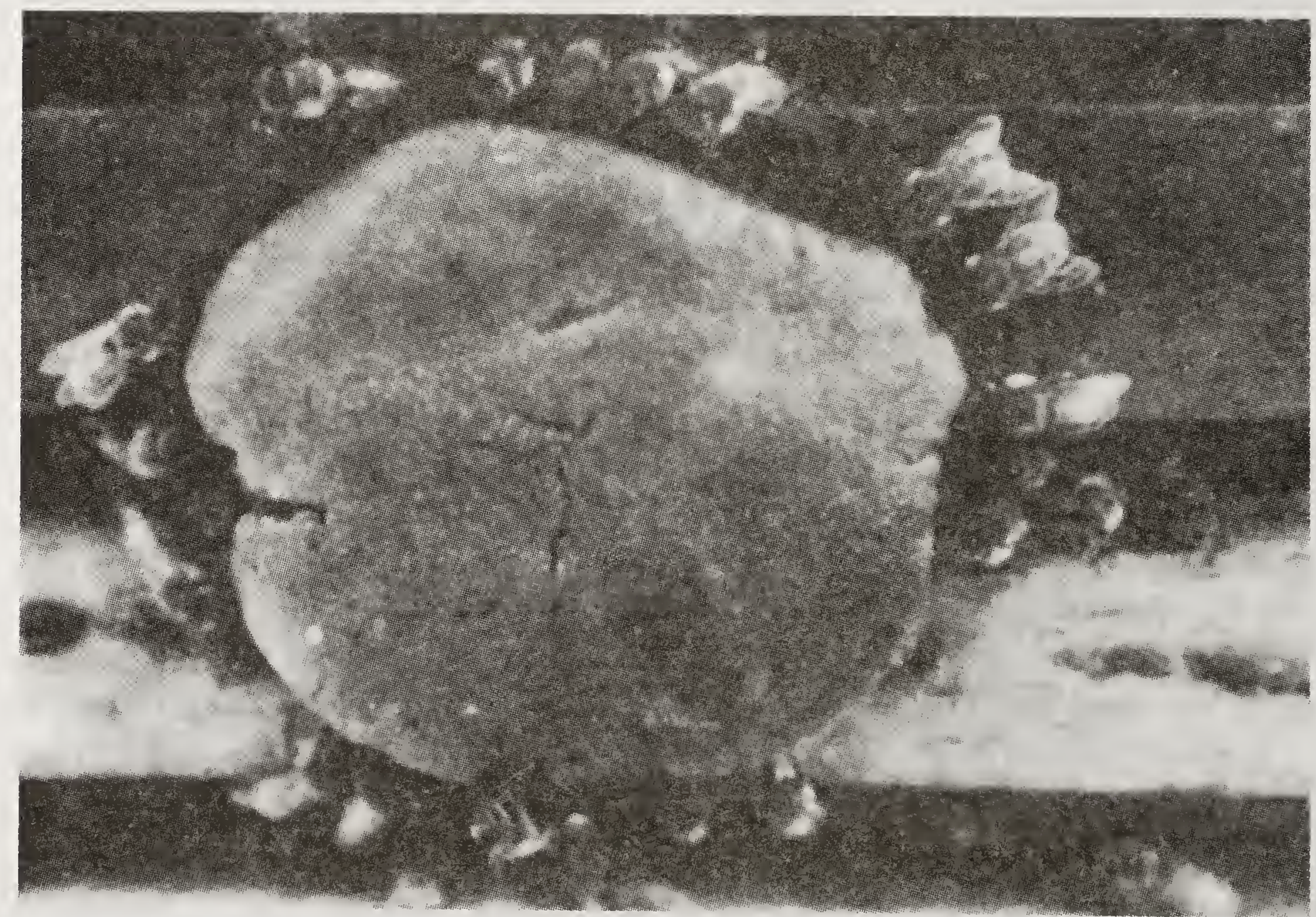

Fig. 33. Pollen supplement placed on the top bars of frames being consumed by bees. 
bees in autumn in hills and during summer in plains boost brood rearing and colony strength for wintering/summering is maintained. Beekeeper can also use these alternatives if pollen shortage affects colony build up before honey flow.

Pollen substitute. Pollen substitute is an alternative to natural pollen and it contains no pollen. Commonly used substitute consists of propellor expelled soy flour, medicinal yeast and skimmed dry milk in the ratio of $3: 1: 1$. The soy flour used to prepare pollen substitute should not contain more than $5 \%$ oil. The nutritional value of pollen substitute can be increased by adding dried egg yolk and casein. The substitute is nutritionally rich for bees but is not as palatable as natural pollen. During dearth period bees collect any powdered substance irrespective of nutrition. Bees have been observed to collect fungal spores and other powders. The mixture of pollen substitute ingredients is made into a dough in concentrated sugar syrup. It is advantageous to add some honey while preparing the dough because the pollen substitute patty hardens in 2-3 days and bees stop consuming it. Honey is hygroscopic and helps the substitute to remain in desired consistency. Divert sugar should be preferred over sugar and honey mixtures for preparing pollen mixtures.

Pollen supplement. Pollen supplement contains natural bee collected pollen. In addition to soy flour and medicinal yeast, natural pollen is added and made into dough after adding divert sugar and sucrose. Honey can be added in case divert sugar is not available easily. The approximate proportion of pollen, soy flour, torula yeast, divert sugar and sucrose are 2:8:8:50:22. The pollen quantity can be increased because acceptability and consumption of the supplement is directly related to the proportion of natural pollen. Five per cent pollen in the mixture is considered to be a very genuine quantily. Bee collected pollen pellets are softened in little water. The sugar is dissolved in water and these are mixed with dry basic substitute.

Pollen substitute and supplements should be made into a consistency that does not rum off. Depending upon the requirement and strength, the size of the pollen patty is given in the colony, on the top bars of the frame. The patty is covered with wax paper from the top and sides so as to avoid drying. Fungi may grow on the pollen patties, and therefore, sulphathiasole at the rate of $1.0 \mathrm{~g} / \mathrm{kg}$ of the mixture should be added.

Providing water. Bees forage for water for elaboration of honey for larval food, for increasing hive humidity or for cooling the hive temperature. To facilitate bees, water can be provided near the apiary. Stagnant or stored water is not good because it can be a source of Nosema infection. Bees collect water more efficiently if it, is available in thin films. Small flow of running water near the apiary can be good provision (Fig.34). Water trickling from a container set on a stand and falling on a slanting wooden plank can be arranged in the apiary. In summer easy access to water saves lot of energy of the colonies.

\section{Communication}

Individual of a social unit should be able to com!riunicate the stimuli to 


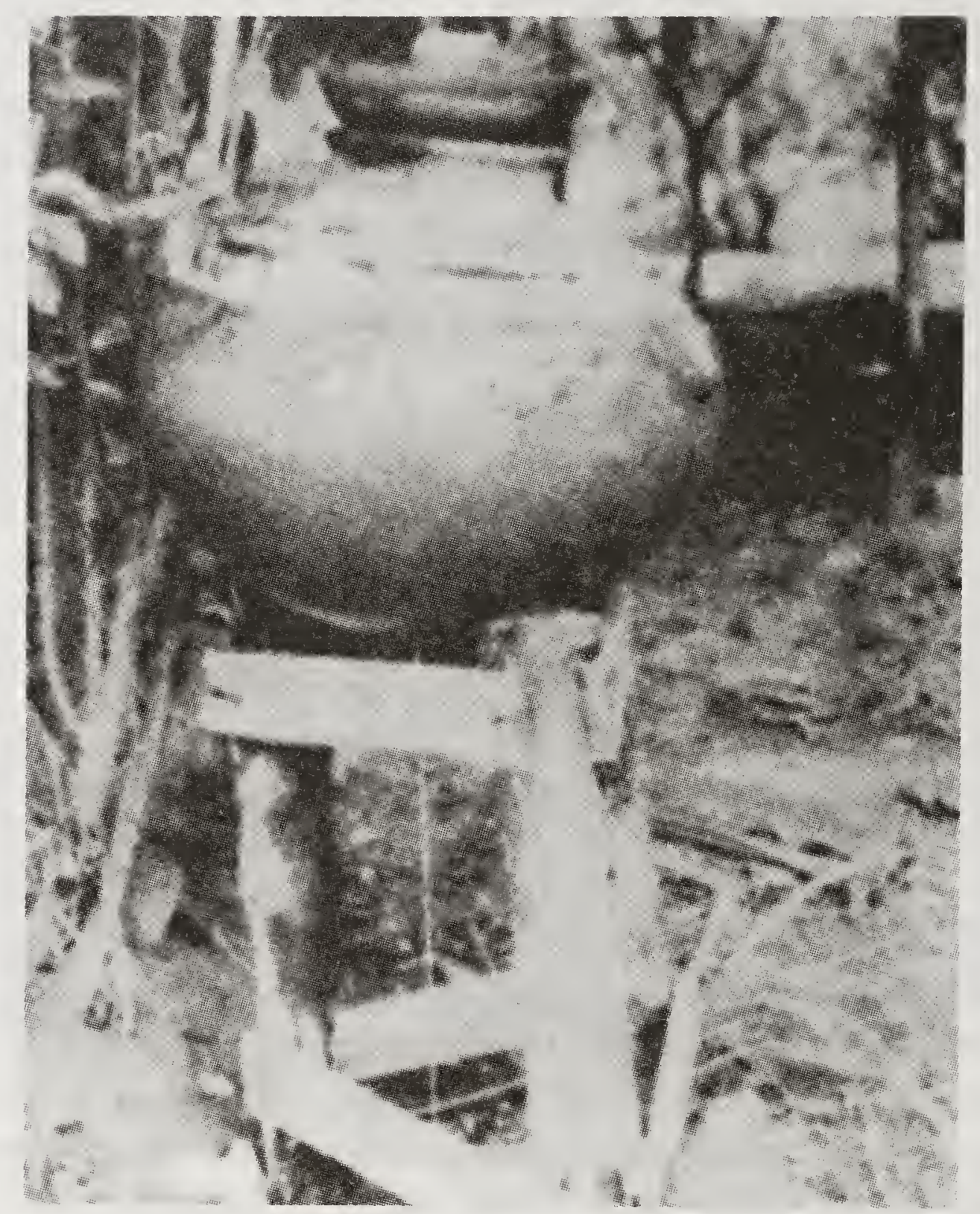

Fig. 34. Provision of water in apiary. The water trickling through a wick fixed in a hole at the bottom of an earthen pot is collected by water gatherers.

other individuals of the species and this is one of the basic requirements for social existence. The transfer of stimuli results into some kind of behaviour in the recipient members. The communication of the stimuli takes place in the dark in the hive. Therefore, vision is not as important as other stimuli such as odour, mechanical and sound. Location of food is communicated by the bees to the fellow foragers in the colony.

Von Frisch (1967) first described that bees can communicate by means of dances, though some details were known earlier (Spitzner, 1788). Von Frisch gave the details and use of dances to communicate the location and value of food sources. He described round and wagtail dances. Round dance is expressed in circles on the comb (Fig.35). The dancer continues for few seconds but changes the direction of the run after few circles are completed. $A$. mellifera bee dancer does not repeat turnings in the direction more than twice but $A$. cerana indica turns in the same direction for number of times (Goyal and Atwal, 1976). They also reported that $A$. cerana indica performed round dance when the food was at a distance of $0.3-7.0 \mathrm{~m}$ and in $A$. mellifera this dance was performed when the food was at a distance of $0.5-27.0 \mathrm{~m}$. But it is commonly accepted that round dance is performed in A. mellifera when the food is located within $100 \mathrm{~m}$ from the hive. There is no indication of direction in the round dance. The dance attracts other bees in the hive, who touch the performer with their antennae. These bees search the source of food 
within $100 \mathrm{~m}$ in all directions, though they use odour as cue for searching the source. The odour is perceived from the body of the dancing forager.

The other type of communication dance performed by the foraging bees is 'wag tail' dance (Fig.35 d-k). This dance is performed to communicate the location of food source when it is more than $100 \mathrm{~m}$ away from the hive. In waggling dance the bee expresses a half circle to one direction, goes straight to the starting point and completes other half circle in the opposite direction from where it again nuns in a straight line. During straight nuns the performer makes waggling motions with her abdomen. Number of wagtail runs per unit time indicate the distance of the source and the number is negatively correlated with distance. Von Frisch found that straight runs per 15 sec were 9-10 when food was $100 \mathrm{~m}$ away but the runs were only 2 when it was at a distance of $6 \mathrm{~km}$. For communicating the direction of source the bees use the position of run. In case the source is in the direction of sun then the straight run of waggling dances is straight upwards on the comb. Source in opposite direction is indicated by downwards straight run. The angle of the straight run with respect to line of gravity is changed by the dancing bee if the food is located to left or right. Bees orient to the position of the sun; polarized sunlight is made use of orientation and thus bee interpret the position of sun in the dark of the hive or even during night. Some positions of hive, food and sun vis-a-vis the directions of straight runs are graphically given in Fig.35. For searching out the sources bees again use odour, perceived from performer's body hairs, as an important cue and find out the source in the a rea.

'Sickle dance' is the intermediate or transition dance between round and waggling dances. The dance is expressed by runs in rough figure of 8 . With increasing the distance of source, waggling movements are introduced by the performing bee at the crescents. Number of waggling movements increase with distance and crescents come closer and at about $100 \mathrm{~m}$ distance the dance is changed to wagtail dance.

Bees return to the source at the specific time of the day. Bees-perform communication dances when the food is found and the time of the day is memorized by the other bees and use the memory to return to the source at the same hour of the day. Foragers retain the memory for 4-5 days, therefore, they keep.on returning to the source even after the food source is exhausted. Number of dancing bees at any time is an indication of the quantity of the food available. Number goes on decreasing with exhausting nectar and pollen in a food source. The bees are able to compensate for sun movements and wind. Dancing bees can calculate the position of the sun without seeing it. Greater distance is communicated when bee has to fly against the direction of the wind, since it involves energy consumption.

\section{Working habits of field bees}

Fidelity. Bees show fidelity to a source, that is they restrict themselves to the blossoms of plants of one species at a time. They shift to other source only when nectar and pollen availability ceases. Bees collect nectar and 


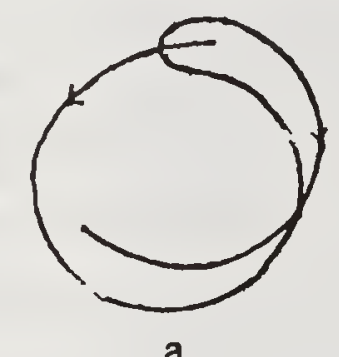

(Round)

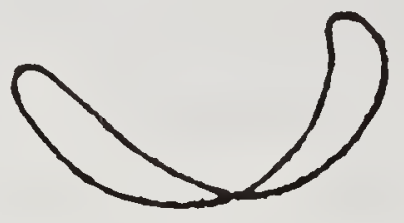

b

(Sickle)

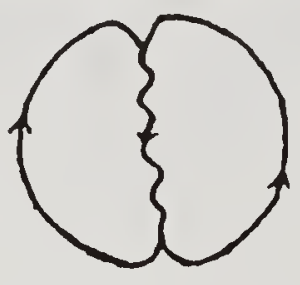

c

(Wag tail)

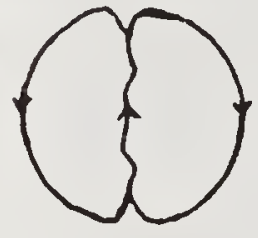

d
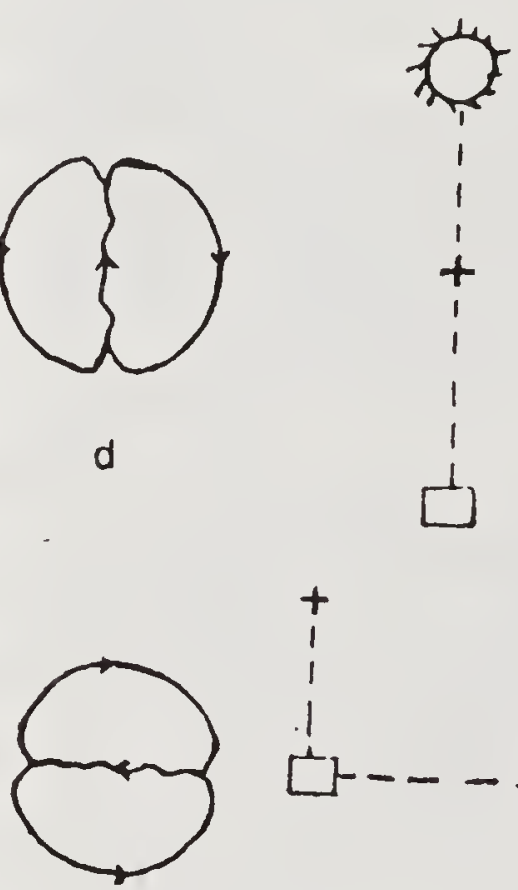

1

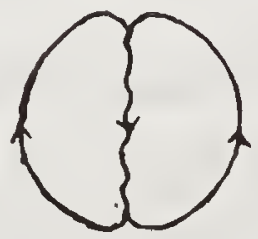

h
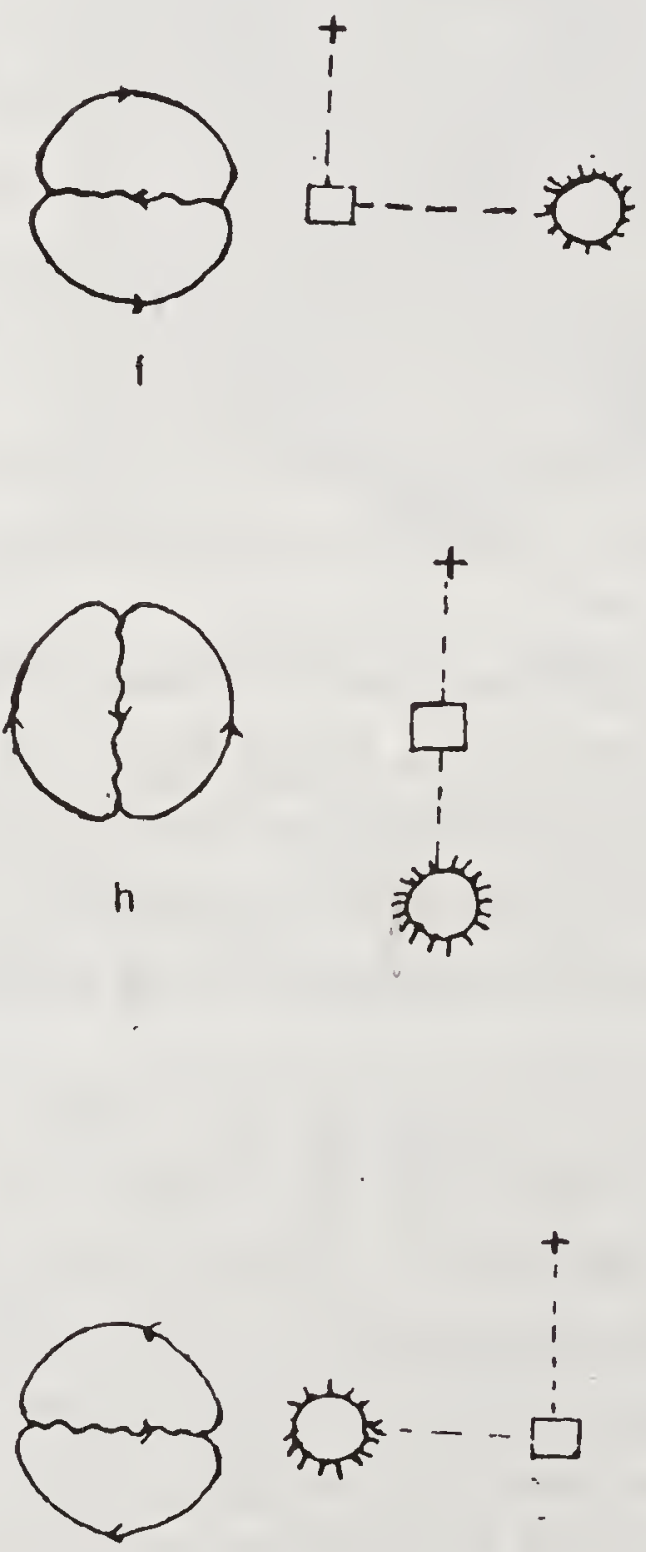
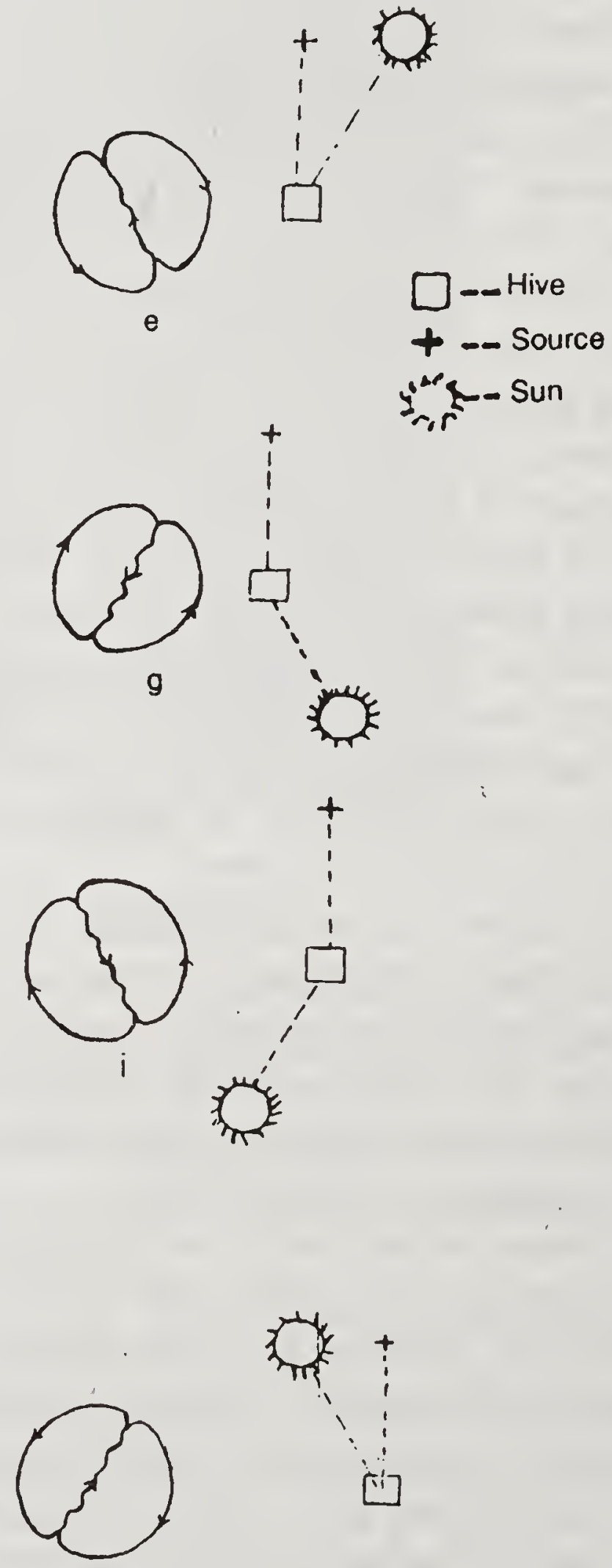

k

Fig. 35. Line drawings of communication dances in honeybee (a-c). Orientations of wagtail run with respect to changes in position of run are shown from $d-k$.

pollen from one species and loads are mixed to a small extent. In India Chaudhary (1978) analysed 5,200) pollen loads and only 56\% contained pollen from more than one plant species. High fidelity has also been observed by Chaturvedi (1973, 1977), Sharma (1970a,b) and Jhajj and Goyal (1979). Dhaliwal and Atwal (1986) found that among the foragers of $A$. florea, $A$. 
dorsata and $A$. mellifera foraging on alfalfa (Medicago sativa L.), 60.0\%, $60.0 \%$ and $66.6 \%$ foragers rèspectively, carried pure pollen loads.

Foraging area and foraging range. Bees restrict their foraging to small areas and they make it possible with the help of landmarks. The foraging area is determined by the number of flowers and amount of nectar and pollens. Bees have to increase the foraging area if there is larger competition from bees or other insects. In South India the foraging range of $A$. cerana indica was $1,780 \mathrm{ml}$ (Cherian and Mahadevan, 1945), whereas it was $1,040 \mathrm{~m}$ in Bihar (Naim and Phadke, 1972). Dhaliwal and Sharma (1972) found that $75 \%$ of the foragers of Indian honeybee went up to $800 \mathrm{~m}$ and $50 \%$ up tc $900-1,100 \mathrm{~m}$. But workers in Indian honeybee flew as far as $3.75 \mathrm{~km}$ to forage on Crocus sativus pollen in Kashmir (Shah, 1980). A. mellifera has longer foraging range of $3-4 \mathrm{~km}$ (Goyal, 1978) but porbably it varies with the flora since the bees of the species did not go farther than $2,000 \mathrm{~m}$ from the apiary and most were less than $1,000 \mathrm{~m}$ away in berseem fields (Dhaliwal and Atwal, 1974).

Foraging speed. Number of flowers visited by a bee depends upon many factors like amount of nectar and pollen, stage of flowering, climatic conditions and also the competition from other insect foragers. Ease with which the nectar can be collected is also important in determining the foraging speed. In some flowers bees avoid the reproductive column and they rob nectar (Fig.36) or become side workers; in such instances the working speed is more. But there are flowers with corolla tube where the forager would take longer time to reach nectar by pushing through the reproductive parts of the flower..Pollen collection is swift in case of flowers where pollen is loose and

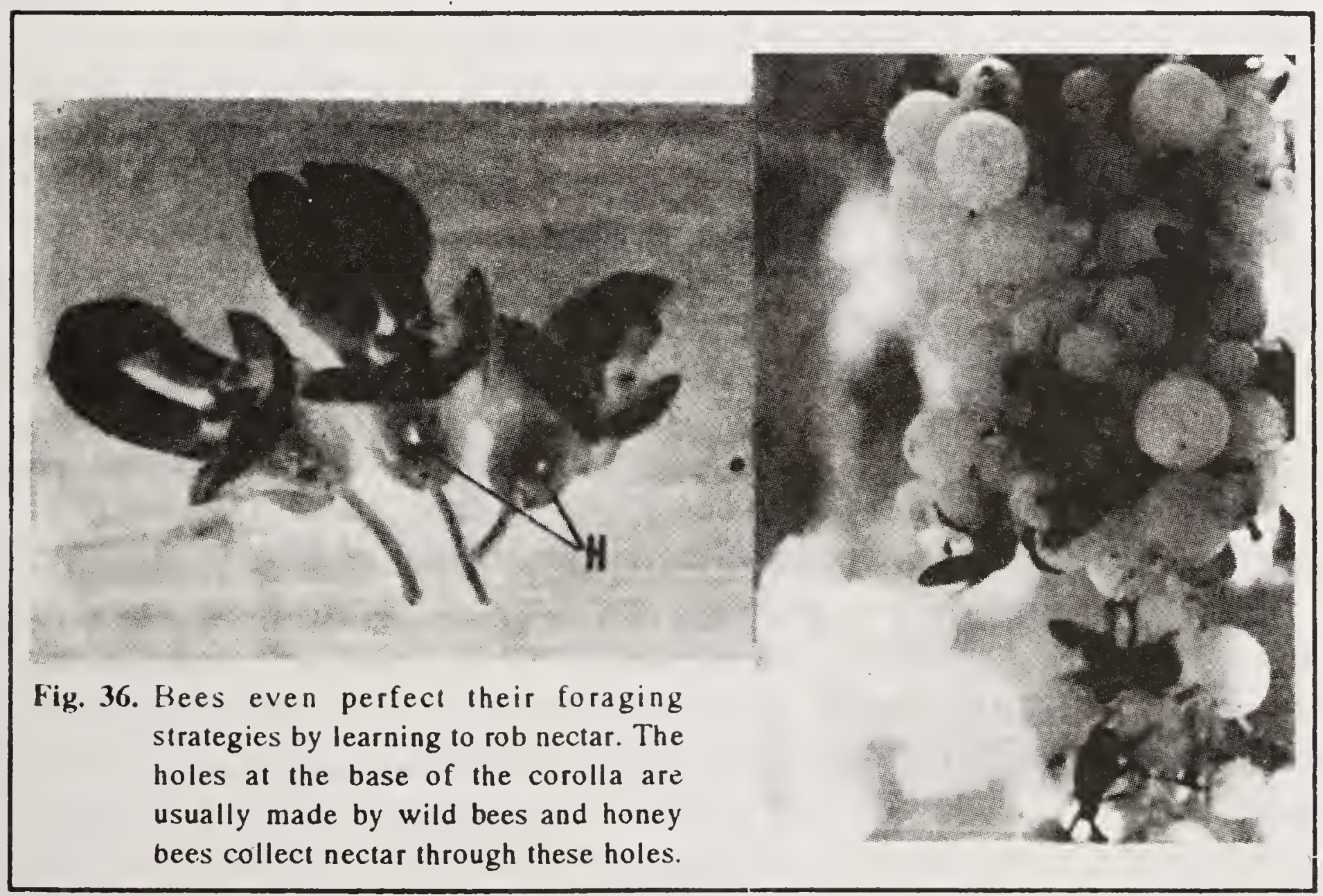

Fig. 37. During dearth period bees collect any sweet material; bees of different species are collecting juice from grapes. 
dry because in such cases bee has just to crawl over the anthers but sticky pollen may have to be collected by biting with mandibles. In the former case the foraging speed is more than in latter. Foraging rate varies with bee species and probaby this is related with their body weight (Dhaliwal and Atwal, 1986). Temporal changes in foraging rate of bees where rate of foraging vary during day hours, has also been established (Kapil and Kumar, 1975; Gupta et al., 1984).

Learning. In the beginning of flowering in a crop, most foragers are top workers. But with experience they perfect their foraging strategies and increasing number shift to side or base working. Alfalfa can be cited as an example where foraging bees learn by experience to trip the flower.

Robbing. Robbing is the habit of stealing honey by bees from other colonies. The tendency to rob boney is more prominent during lean period. At such times, the bees may visit anything which is sweet (Fig.37). In this venture they even try to rob honey from weak colonies. Exposing honey combs for longer time during colony examination causes robbing because bees get the flavour of honey. Spilting of honey or sugar syrup drops near the hive and disturbing the bees are other factors responsible for inducing robbing. Colonies become prone to robbing when honey is extracted late in season, that is after the flow is over.

Robber bees try to enter the hive through cracks, crevices and holes other than main hive entrance and avoid guard bees. If they do not find any place to enter then they try to force their way through the main intrance. These foreign bees are intercepted by guard bees and there can be fight where any of the adversary may be killed. Both the robber and robbed colonies suffer heavy casualties. If the robber manages to enter the hive then many other robbers follow and the colony gets demoralized and become helpless. Robber bees fly around the colony with a feeling of guilt. They also appear darker in colour which happens because they lose body hairs. As a result of robbing the colonies become weak. There are dangers of spread of diseases. Colonies become extraordinary alert and such colonies store less honey during periods of intense alertness. In the event of severe robbing the colonies can lose their queens. Robbing is not very serious if it occurs within an apiary of a bee species but robbing in between the species may lead to colony losses. Severe robbing by $A$. mellifera in $A$. cerana indica colonies during dearth is ulicontrollable (Atwal and Dhaliwal, 1970). A. cerana bees also rob mellifera colonies especially at lower temperatures (Adlakba and Sharma, 1974). Similarly robbing by $A$. dorsata finishes the colonies of domesticated bees.

To prevent robbing it is necessary that the hives be made bee-proof and hive entrance be reduced so that bees can effectively guard it. During summer dearth period the colonies also require ventilation and reducing hive entrance could reduce ventilation. To increase ventilation brood and super chambers are slightly lifted with wooden splinters for cross circulation of air. Sugar syrup should be fed late in the evening inside the hives if needed. No syrup should be spilt out the hive. During dearth, colony examination should be avoided and if essential it should be quickly done. 
If in spite of precautions robbing breaks out the entrances of all colonies in the apiary should be reduced. Wet grass placed in front and at the top of the hive is useful. As a last resort the position of the colony being robbed should be exchanged with that of robbers colony. The colonies being robbed can be moved away from the apiary and an empty hive paced in its place.

\section{REFERENCES}

Adlakha, R.L. and Sharma, O.P. 1974. Intra specific robbing. Am. Bee J. 114(7) : 248-49

Atwal, A.S. and Dhaliwal, G.S. 1969. Some behavioural characteristics of $A$ pis indica F. and $A$. mellifera L. Indian Bee J. 31(1) : 1-8.

Atwal, A.S. and Dhaliwal, G. S. 1970. Robbing between Apis indica F. and Apis mellifera L. Am.Bee $J .109$ (12) : 462-63.

Chaturvedi, M. 1973. An analy sis of honeybee pollen loads from Banthra, Lucknow, India. Grana, 13 (3) : 139-44.

Chaturvedi, M. 1977. Further investigations on the pollen analysis of bees loads from Banthra, India. New Botanist. 4 (1-4): 41-47.

Chaudhary, R.K. 1978. Floral fidelity in the Indian honeybee (Apis cerana indica F.). Indian Bee $J .40(2): 239$.

Cherian M.C. and Mahadevan, V. 1945. Preliminary studies on the pollen carrying capacity of the Indian bee (Apis indica F.). Indian Bee J. 8(7/8) : 109-11.

Dhaliwal, H.S. and Sharma, P.L. 1972. Homing ability and the foraging range of the Indian honeybee, Apis indica F. Indian J. Ent. 34(3) : 225-27.

Dhaliwal, J.S. and Atwal, A.S. 1974. Foraging range of Apis mellifera L. on berseem (Trifolium alexandrinum L.) at Ludhiana. Indian Bee J. 36(1-4) : 17-18.

Dhaliwal, J.S. and Atwal, A.S. 1986. Factors influencing tripping efficiency of bees on alfalfa (Medicago sativa L.). In Pollination Biology : An analysis. (Ed. R.P. Kapil) Inter-India Publications, New Delhi, pp. 79-90.

Frisch, K. von. 1967. The Dance Language and Orientation of Bees. The Belknap Press of Harvard University Press, Cambridge, Mass (Trans. by L.F. Chadwick).

Goyal, N.P. 1978. Performance of $A$. mellifera over $A$. indica as observed in Punjab plains. Indian Bee J. 40(1) : 3-5.

Goyal, N.P. and Atwal, A.S. 1976. Comparative communication behaviour amoung Apis cerana inidica and Apis metlifera L. : dancing behaviour. Indian Bee J. 38(1-4) : 1-2.

Gupta, J.K., Mishra, R.C. and Kumar, Jitender. 1984. Plectranthus as forage for Apis cerana indica F. and Apis mellifera L. Apidologie 15(1) : 75-82.

Jhajj, H.S. and Goyal, N.P. 1979. Comparative studies on the flower constancy of Apis cerana indica F. and Apis mellifera L. Proc. 4th Int Symp. Pollen; Maryland, 1978 (1979):333-39.

Kapil, R.P. and Kumar, S. 1975. Foraging activity of A. dorsata Fab. on Brassica juncea Hook, Thomas. J. Bombay Nat. Hist. Soc. 71(2) : 327-331.

Naim, M. and Phadke, K.G. 1972. Flight range of A pis cerana indica when enticed to a feeding dish. J.apic. Res. $11(3): 167.69$.

Sharma, M. 1970a. An analysis of pollen loads of honey bees from Kangra, India. Grana 10 : 35-42.

Sharma, M. 1970b. Studies on the pollen loads of honeybees from Kangra, India. J. Palynol. 6 : 104-10.

Singh, G. 1971. Sucrose solution imbibing capacity of Apis indica F.(hill strain) in relation to various sucrose solution concentrations and body weight. Indian Bee J. 33(3/4) : 51-54.

Singh G. 1972. Defensive behaviour of Apis indica F. (hill strain) against predatory hornets in Kashmir. Indian Bee J. 34(3/4) : 65-69.

Spitzer M.J E. 1788. Ausfiihrliche Beschreibung der Korla. 


\section{INSTINCT OF REPRODUCTION AND RELATED MANAGEMENT}

REPRODUCTION instinct is a guiding force to succeed in future existence and influence almost all colony activties. Bees accumulate large quantity of food for provision for the young ones and young adults in the colony. The food gathering behaviour of hive-bees is thus governed by the reproduction instinct. Comb building is hastened by the hive-bees if the need for new cells for egg laying is more. Comb building is of good quality and is mostly that of worker cells during spring when reproduction instict is at the highest. Hive-bees also cope up the requirements by cleaning and polishing the cells. When the colonies attain a sizable strength the drone cells are raised and drones are reared during breeding season. To satisfy the instinct of reproduction of species, such colonies prepare for swarming.

\section{Control of reproduction}

Reproduction in bees is a social behaviour of social existence. All worker bees are females but the reproductive system is not developed and only queen is responsible for egg laying but the colony functions as a unit. Worker bees have underdeveloped ovaries and these can develop when necessary suppresants are not functioning. Queen secretes a pheromone, called queen substance (9-oxo-2-decenoic acid) from mandibular glands. The queen substance is spread on the body of the queen and worker bees lick the queen and acquire this pheromone which they also share with other workers by trophallaxis.

In virgin queen this substance attracts drones on mating flight. The social organization breaks down in case of absence of queen substance and this can be beacuse the queen is lost or there is some disruption in reaching the substance to worker bees. The latter condition can develop when the colony becomes overcrowded or the queen is incapable of laying eggs (Figs. 38 and 39 ) and has exhausted the supply of sperms. Under these circumstances new queen cells are raised. In case a new queen does not take the place of oldlaying queen the ovaries of worker bees develop and start laying unfertilized eggs. The individuals reared from eggs laid by such workers are baploid males.

\section{Queen and its management}

Success of a colony depends upon the quality of the queen which heads it. There are certain criteria which can be used to assess its quality. Physical characteristics give useful information for judging a queen; good queen should be large with broad and long tapering abdomen and uniform body colour. 


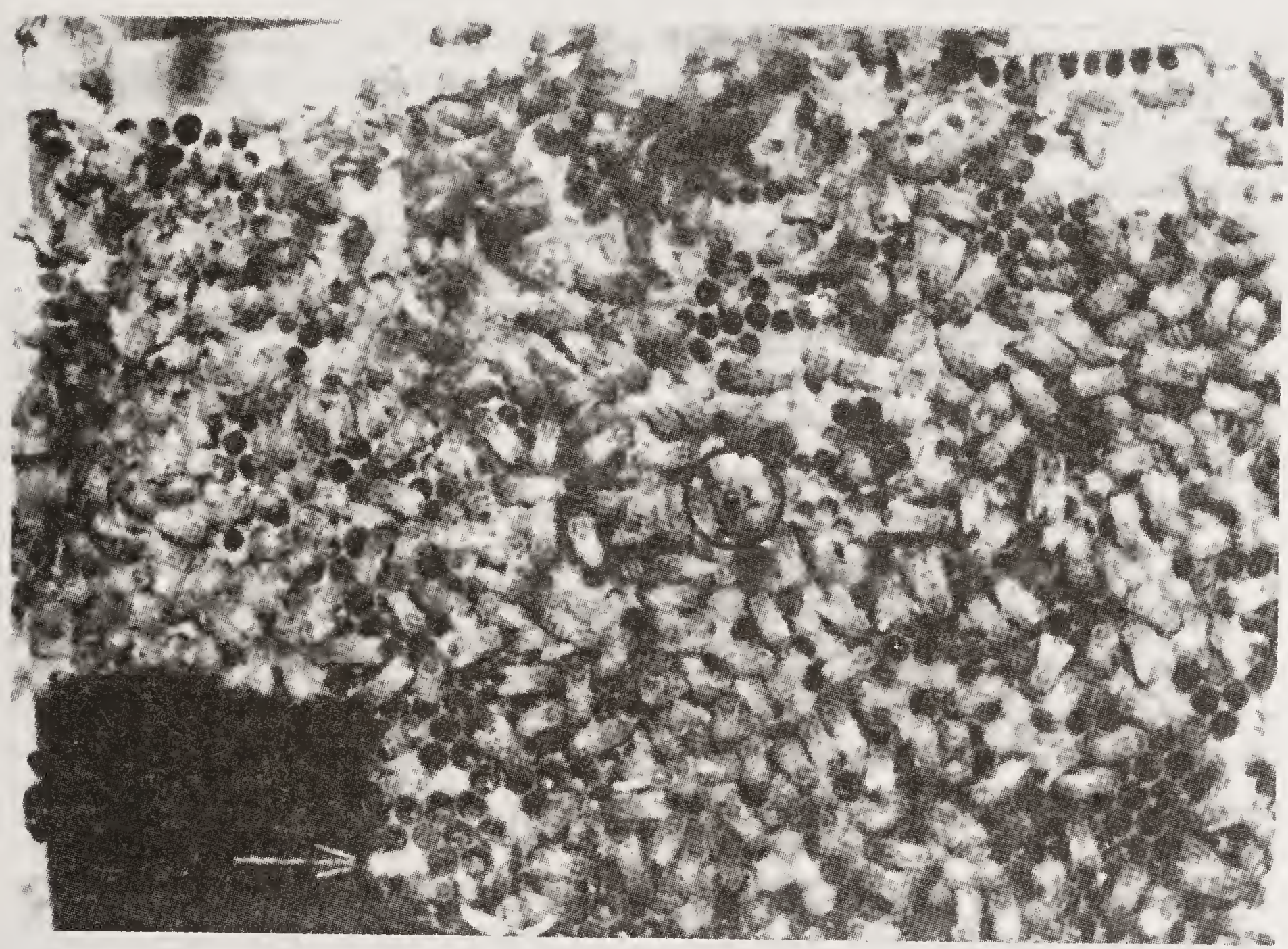

Fig. 38. Haphazard and unsystematic egg-laying and brood-rearing in a colony headed by old failing queen. More drones being reared.

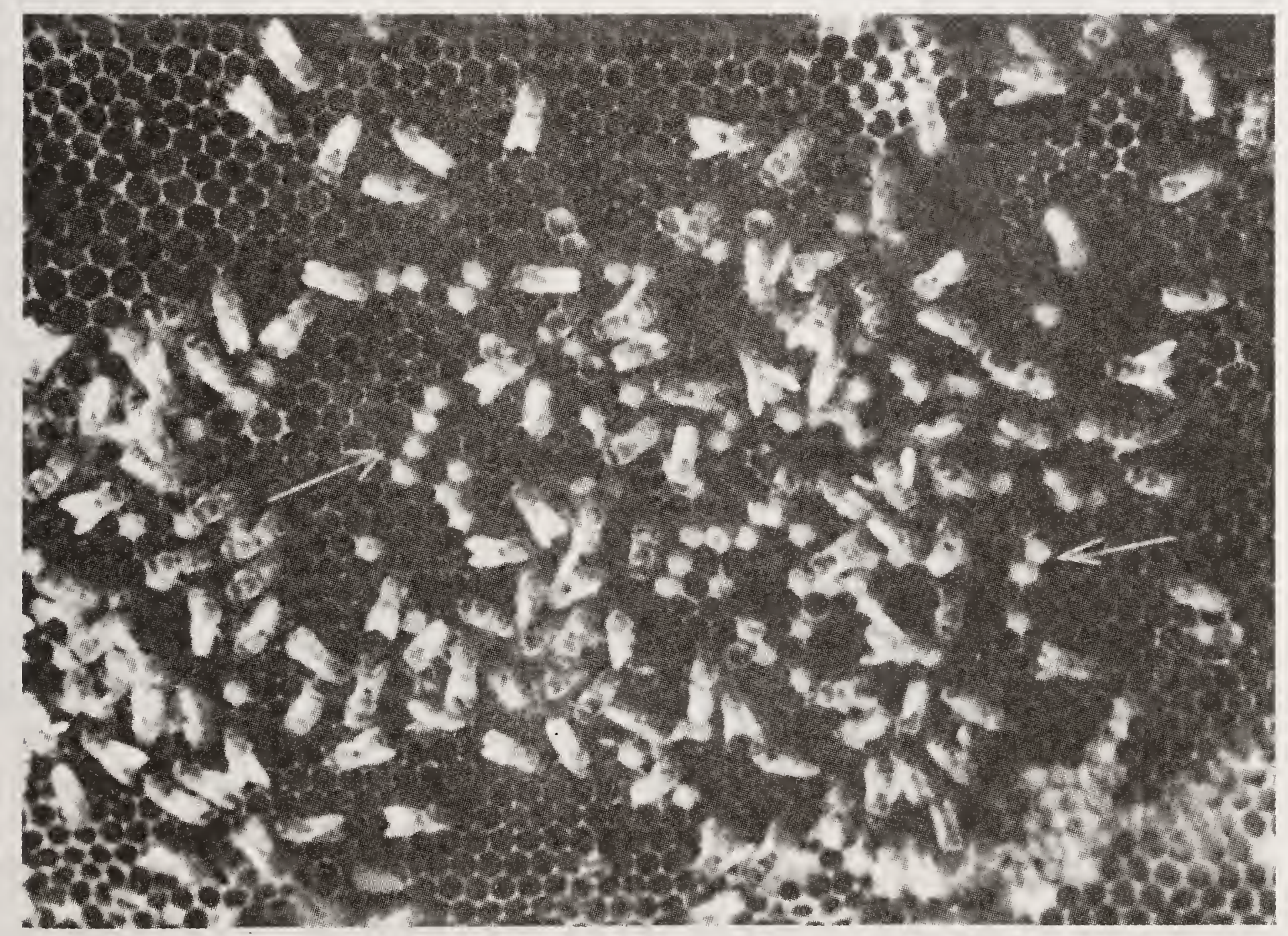

Fig. 39. Haphazard and unsystematic egg-laying and brood-rearing in colony headed by oldfailing queen. Almost all brood being reared is drone brood.

While judging a queen, the egg-laying pattern should be taken into consideration. A good queen will start egg laying from little above the centre 
of a comb and eggs are laid in concentric circles. Good queen lays eggs in the bottom of the cell and all eggs being slanting almost to the same direction. Colony should be built up to have enough field force to avail the flow, therefore a queen should always start laying large number of eggs much before the boney flow season. If the colony build up is late during or after honey How then it cannot be a profitable unit.

Queen is also judged through the performance of her progeny. Worker bees of a queen should be good honey gatherers, colony should be able to abridge over unfavourable seasons during the year and above all should be disease resistant.

A queen has multiple matings and the workers produced from the sperms from different drones would vary with respect to their characteristics. Because of this reason a queen may be adjudged good at one time but her performancce can be poor at the other time.

Queen can live up to 3 years but duration of her active egg-laying capacity varies with localities. In good beekeeping areas, with plentiful of flora, a queen may get exhausted in 1-2 years but in marginal and poor areas the pressure of egg laying is less and a queen may continue to perform well for 3 years. Therefore the replacement of a queen cannot be guided by any fixed rule and the experience of a beekeeper is a valuable guidance in this respect.

For Apis cerana indica, 2 years is a safe period for replacement of a queen. But in case of $A$. mellifera in sub-tropical plains of India, there is heavy pressure of egg laying from November to May. With a short cessation or reduction in egg laying during summer, she again starts egg laying, of course lesser in number, from August. In such areas there arises a need to replace the queen every year. Though drones are available in a colony from December onwards but the best time to replace the queen in such areas is mid February to mid April. During this period the mating success is as high as $90 \%$. The queens are of better quality and store more number of sperms in their spermathecae. Colonies headed by new queens are more successful in summering than those headed by older queens. If the queens are not replaced every spring, greater percentage of these are lost or superseded during summer and rainy season when there are no or very few drones and queen mating chances are virtually negligible. Queens also do not successfully mate during summer, i.e., after mid April. In mountainous and submountainous areas the queen raising and mating period is late than in warmer plains.

Queen nuclei and mating yards. Small nuclei are raised for mating of new queens. It is profitable proposition to waste the efforts and time of small nuclei than of full strength colonies. A queen after emergence takes 5-7. days to sexually mature. Mating can take place any time after a week or so and queen sta rts laying after 2-3 days of mating. Most queens of Indian boneybee mated on 6th day and started egg laying on 8th day (Shah and Shah, 1980; Sharma, 1951). A. cerana indica queens also have multiple matings like $A$. mellifera (Sharma, 1960). A. cerana indica queens take mating tlights in the afternoons and average duration of the flights is $27 \mathrm{~min}$. (Woyke et al., 
1972). There is no brood rearing in nuclei/colonies for 3-4 weeks which rear their own queens and queens allowed to mate in the same nucleus/colony, thus house bees are virtually idle for a long time. It is advisable to waste the energy of small number of bees. The nuclei should be rendered queenless without being completely demoralized. Queenlessness for $24-48$ hours is enough to accept the ripe queen cells. The mating nuclei are made with bees, emerging brood, honey and pollen. Virgin queen can mate even when there are 200-300 worker bees in the queen mating nucleus. But these bees are incapable of regulating temperature in case of inclement weather. Normally 2 frame nuclei are appropriate for queen mating. It should be ensured that the combs in these nuclei have food stores and feed sugar syrup if stores are inadequate. The nuclei can be of 2 types. In one case the frames are one half the size of normal frames and 3-5 such frames are used. In this case, operating the nuclei is difficult because brood cannot be given from standard hives and special colonies have to be maintained for the supply of brood. The other type of nucleus has the standard frames but accommodates only 2 or 3 frames (Fig.40).

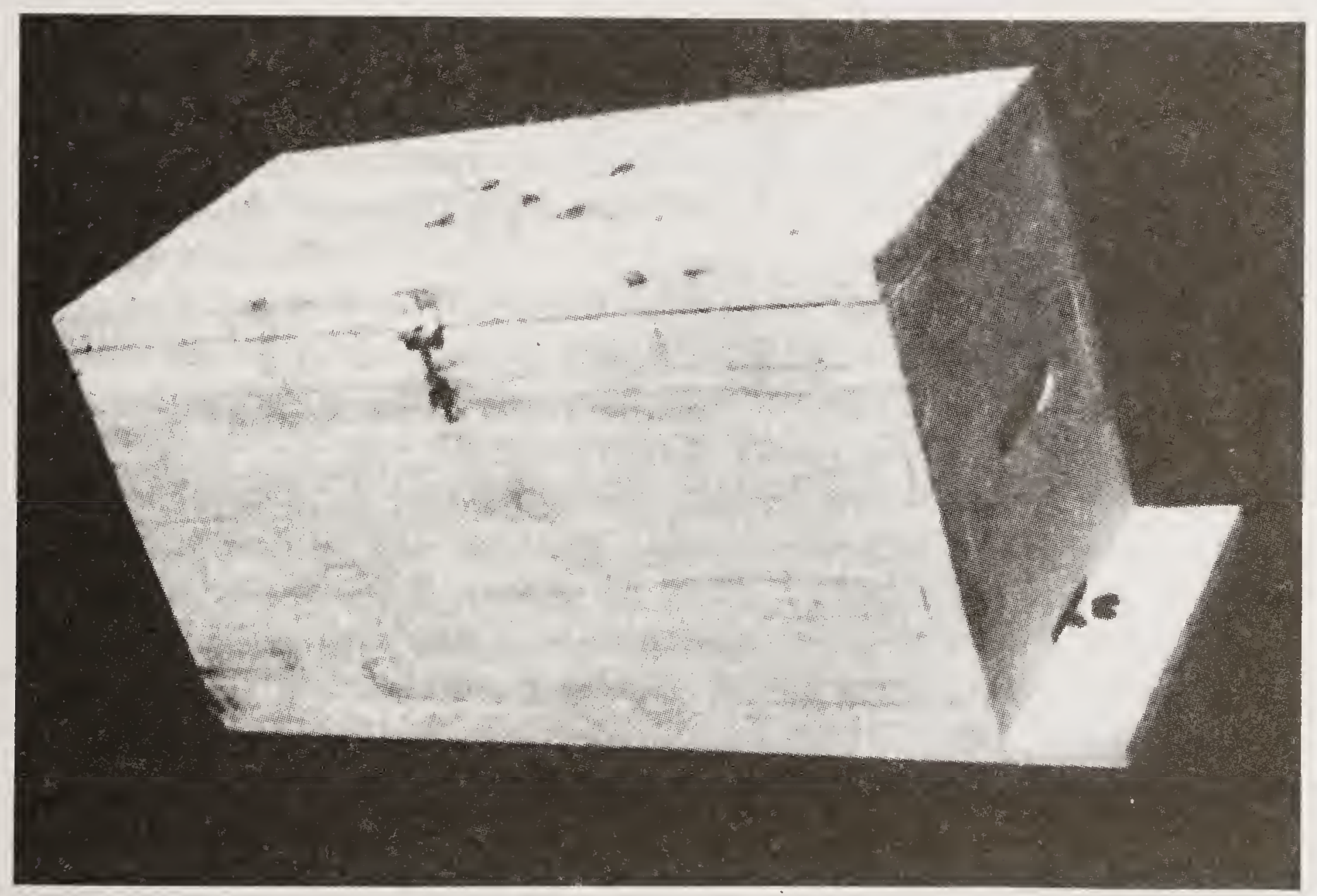

Fig. 40. Nucleus hive with full-length frames for queen mating.

Mating nuclei can be set in a mating yard for mating and a large number of these can be kept at a place. It is important that nuclei have enough drones or drones are available in the close by apiaries. Drones in vicinity can participate in queen mating because it is now established that queen mating takes place in drone congregation areas. Queens after orientation or mating flights can miss their mating nuclei by confusion. The drifting of queens can be reduced by placing the mating nuclei at random with entrances facing different directions. Marking of nuclei with figures of different planes 'will 
further reduce drifting since these serve as orientation marks. The queen after mating is allowed to lay eggs and thus in few days this will have brood in all the stages. The mated queen is removed for requeening the desired colonies and the mating nuclei can be reused without restocking.

Queen introduction. After emergency or successful mating the queen is to be introduced into a colony with old and failing queen. Queen may also be required to be introduced into a queenless colony which has lost its queen due to other reasons. It is essential for the beekeeper to remember that: (i) Mated queens are more readily accepted than the virgin queens. (ii) If the new queen lays eggs about equal in number to those laid by the queen to be replaced, it is easily accepted. (iii) During nectar flow all the bees are busy with their respective duties and queen introduction during flow is easy. (iv) Queen to be introduced and the bees of the colony have different odours and therefore gradual intermixing of odours will help successful queen introduction.

Different types of cages, according to beekeeper's convenience, are used for queen introduction. All types of cages permit feeding of the queen through bardware screen and thus workers get acquainted with the queen odour in due course. The cages should bave no place for the bees to enter or for the queen to come out. The cage with queen and some attendant workers is placed in between 2 brood nest combs. The caged queen is released after 24-48 hr and is watched for sometime for her behaviour and the behaviour of bees towards her. She may be balled in case of non-acceptance and in this case she is again removed and recaged. Releasing can be tried after another 12-24 hr.

Cages with narrow tunnels are also in use for queen introduction. Both the tunnels are filled with candy. The shorter tunnel is fixed with queen excluder at the inner end. One bee at a time can enter or come out of the queen cage. Some more time is taken to consume the candy of the longer tunnel. The queen is released after this candy is finished.

Completely disorganizing the bees and introducing the queen directly is another method of queen introduction. The bees can be disorganized by smoking. The queen is mixed up in the colony before the bees become normal. Shaking bees from the comb in front of hive entrance and releasing queen among bees crawling up the plank of hive entrance is also a method of queen introduction. But the queen is precious and taking risk of losing the queen under these methods is not advisable.

As stated earlier, the queen introduction is easier during nectar flow. The condition can also be artificially created by continuously feeding sugar syrup to the colony during queen introduction manipulations.

\section{Laying workers}

Worker bees are females and their reproductive organs, though present, are not developed but the system does develop under specific circumstances. Ovaries of some worker bees are slightly more developed in a colony. They further develop when the influence of the queen substance is lost under queenlessness condition. Worker brood, in all stages, has an inhibitory effect on the development of laying workers. Since laying workers lay unfertilized 
eggs, therefore, drones develop in worker cells. These drones are smaller in size than normal ones raised from unfertilized queen eggs but are sexually potent.

Laying workers lay eggs in baphazard pattern, in patches, not placed in the bottom and centre of the cell and more than one egg is laid in each cell (Fig.41). They have shining bodies. Some laying workers also bebave like queens and these false queens have weak entourage of bees. Activities of queenless colony are also affected, the foraging activity, load carrying capacity and comb building are adversely effected. With the rearings of large a mount of drone brood, the worker bees become hostile to laying workers. Queen introduction in such colonies is a tedious job.

There are differences among the species in the appearance of egg laying workers. In $A$. mellifera the appearance of laying workers is delayed as compared to Apis cerana indica. Similarly in African bees ( $A$. mellifera adansoni), the appearance of laying workers is quick. In A. mellifera capensis there is a peculiar phenomenon. The worker bees are produced even from unfertilized eggs and in case the colony loses its queen, a new queen is raised from the eggs laid by laying workers. Even in normal queen right colonies of cape bees there are some worker bees with well-developed ovaries.

\section{Reproduction of species - swarming, prevention and control}

All living animals bave a natural instinct for uninterrupted continuance of the species. The honeybees swarming means reproduction or natural increase in number of colonies. Colony is a biological unit and in its instinct for existence of species it is essential to have small colonies than few strong ones. In the attempt to satisfy this urge the bee colonies issue several swarms in a season. The swarms search out good sites for permanent settling. Thus the new colonies are not concentrated in the same locality and disperse to new area. This reduces competition for flora and increases the chances of survival of species.

With the onset of spring or in winter where plentiful of Brassica flora is available and winters are not severe, the egg-laying rate is increased by the queen. The workers provide glandular food to queen more frequently. Some workers always surround the queen, touching and licking ber and virtually make her to continue laying eggs. The colony builds up in strength and in the second phase the worker bees build combs with drone cells if not already avilable in the combs. The queen lays unfertilized eggs in drone cells. After the drones have appeared in the colony, the next step is raising of queen cells. The queen is not attended fully well and she shrinks in size. She has to beg for food from nurse bees and activity of her sexual organs diminish, and egg laying is reduced just before swarming. She loses in weight and now can fly with the swarm because egg laying queen cannot fly even short distances. Because of reduction in egg laying rate, the nurse bees in the colonies are not fully occupied and some of them become idle thus throwing the colony in a sort of disbalance. More number of queen cells (Fig.42) are raised by $A$. cerana indica colony under swarming (9.0) than under 
supersedural (2.5) impulse (Sharma, 1960). As the new queens a re developing the activity in the colony gradually reduces. Reduced number of foragers collect nectar and pollen and the young bees of 5-20 days old do not perform any job. These young bees are more potential to do the heavy work of establishing a new nest, therefore, in the course of evolution, these young bees leave with the swarm. The searcher worker bees explore the sites for nesting and they communicate the prospective sites by performing communication dances. The bees agree at the most suitable site and the swarm leaves the parent colony and remains at the temporary site for $24-48$ hours. Afterwards the swarm leaves for the permanent nesting site which can be even some kilometres away from the parent colony.

Swarm goes out in the forenoon on clear sunny days. More than half of bees in the colony accompany the old queen. Some drones also go with the swarm. The drones may not be required since the old laying queen is mated but old queen may be exhausted and the swarm may need to replace the failing queen. In that eventuality a new queen is to be raised by the new swarn and nature has ensured the availability of drones for mating. The first 'prime swarm' leaves the parent colony when the daughter queen is about to emerge. New queens emerge on the same day or till the 9 th day of swarming in $A$. cerana indica (Sharma, 1951). The swarming ínpulse may cease after the departure of first swarm. But in case of strong colonies one to three secondary or 'after swarms' are issued.

The swaming tendency may be accentuated by several natural as well as artificial conditions. Among the former are on rush of sudden honey flow and colonies with older queens. The older queens have low egg-laying capacity, though this may not be evident in early spring but by the onset of boney flow, such queens get exhausted. Some of the artificial conditions a re heat, lack of ventilation, shortage of space for egg laying and for honey storage, artificial barrier of poor drone and honey combs in between worker brood combs. These conditions produce congestion in the hive. Congestion is a state or condition which leads to swarming but it is not the motive or cause of it.

Swarming instinct is not uniform in all the colonies and this also varies in races of a species and between the species. This is an inherited trait of bee colonies. Colonies with low swarming instinct build less drone combs. Working rhythm of such colonies is smooth and they reach maximum strength by the main flow season. It is proper to make efforts to replace queens whose colonies swarm too much with those from less swarming tendency. Indian honeybee is more prone to swarming as compared to A. mellifera. In Punjab most $A$. mellifera colonies consisted of 65,000 to 70,000 bees but did not swarm, however, most $A$. cerana indica colonies swarmed before reaching a population of 18,000-20,000 (Goyal, 1978a).

Catching and hiving a swarm. Swarm settles at a temporary site after it goes out. The temporary site is usually very close to parent colony and this site is low shady bush, branch of a tree or wall of a house. Catching a swarm is not a difficult job if the access is easy. A swarm box with raised combs can be profitably used. The swarm box or nucleus. hive is set under the swarm 
and bees are shaken and brushed on the top bars of frames. Once the queen has entered the box, all other bees follow. The swarm box is left within about one metre of place where swarm had settled. The top of the swarm box is covered and all the flying and left out bees enter the hive through the hive entrance. The swarm box with bees can be shifted in about half an hour to the place where the new colony is to be kept.

Depending upon the convenience and accessibility, alternate methods can be employed to catch a swarm. Swarm bag with wire ring fixed around the mouth can be more convenient if the swarm is hanging to a high tree. The mouth of the bag is brought close to the swarm and the swarm is made to fall in the bag by giving a jerk to the branch and by scoping the bees with wire ring on the mouth of the bag. The mouth of the bag is closed and bees are brought to hive where it is to be hived.

Use of swarm basket is also common for catching swarms. It is a matted, conical small basket with wide mouth. The basket is placed just above the swarm and the bees are pushed upwards. Bees start moving and in a couple of minutes all bees go into the basket. The swarm basket is usually made of bamboo mattings and is plastered with cowdung. The swarm can be shifted to the hiving place by keeping the basket in inverted position, the mouth of the basket may be covered with muslin cloth in case the swarm has to be taken to longer distances.

It is rather difficult to catch a swarm if it is in cavity or hollow of tree or wall. In such cases funnel method can prove useful. All the exit holes except the main entrance are plugged. The main entrance is fixed with a wire netting funnel with a narrow apex hole. The bees which come out do not find way to enter into and all workers are drawn off. A hive with combs is placed near the apex of the funnel for shelter to bees which do not find way into the nest. Smoking may help to force out the bees from such cavities but it is not a useful method because workers are very hard to drive out of brood nest combs and queen also does not leave the combs. Mild smoking can be attempted but heavy and persistent smoking can lead to loss of the swarm by stupefection of bees.

For hiving a swarm, a new hive is set up. This hive is given with a brood comb and combs with honey and pollen. The swarm cluster along with combs in swarm box or nucleus hive is transferred to the new hive. All other bees are shaken near the bive to climb to the entrance through a slanting surface (Fig. 43). In case of swarm bag or swarm basket all bees are dumped into the arranged new hive by giving a sharp jerk. The freshly hived swarm need liberal feeding till it settles down.

It is not profitable to allow swarming for rational beekeeping and honey production is seriouly affected. Neither the swarm nor the parent colony may be in a position to gather surplus honey to give to the beekeeper. To keep a watch, catch and hive the swarms under natural swarming conditions are labour consuming. For honey porduction the swarming is to be prevented and controlled but in case a swarm goes out, the same can be returned to the parent colony. The swarm is hived in a newly set hive at the place of the 

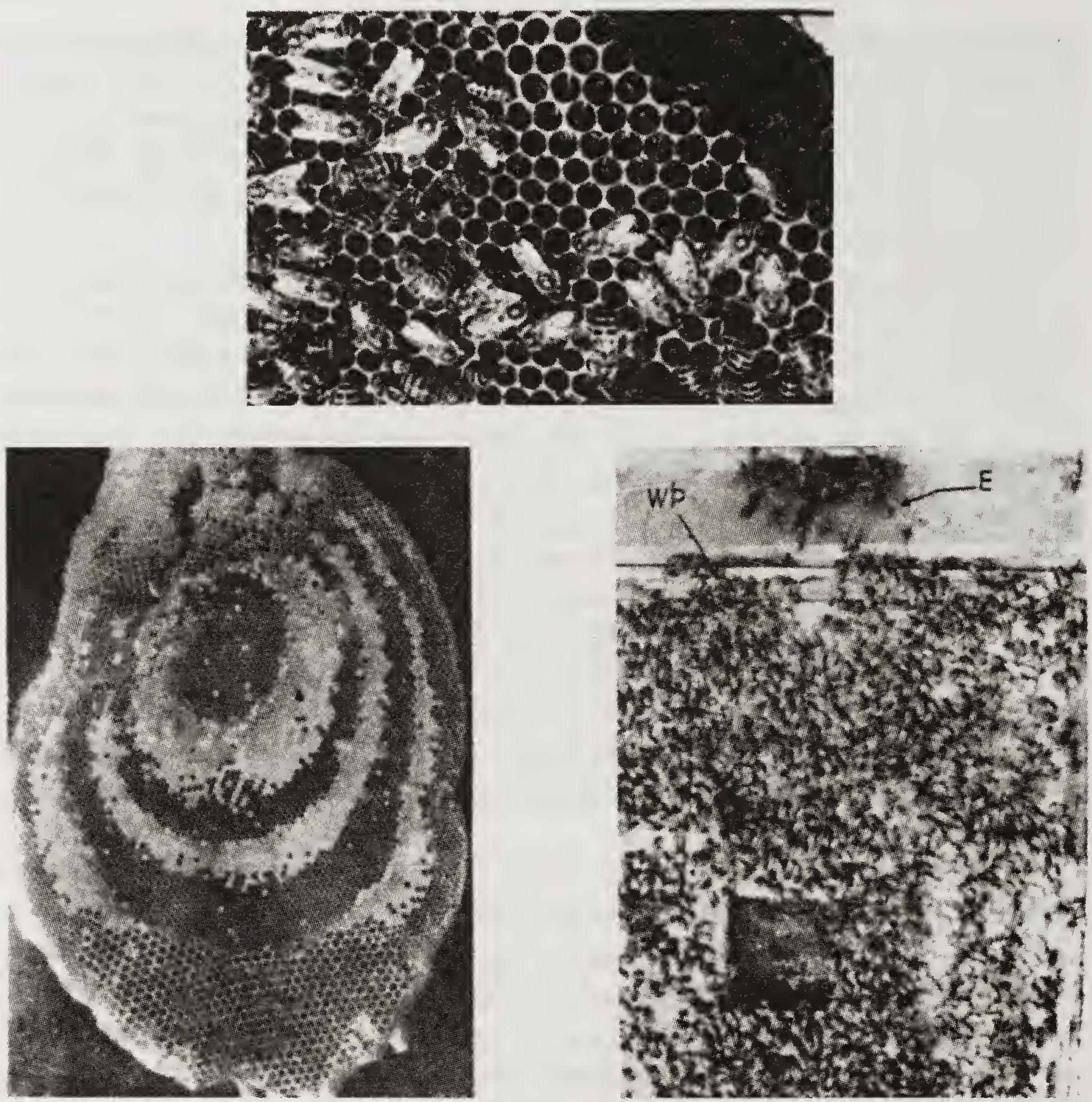

Fig. 41. Eggs laid by laying workers in a queenless colony of Apis cerana indica.

Fig. 42. Queen cells raised on the margins of comb under swarming instinct.

Fig. 43. Hiving a swarm: bees shaken in front of hive are climbing through a slanting surface to the entrance.

parent colony. All other combs in the parent colony are examined and all queen cells are destroyed. These bees with frames are put on top of the swarm with a queen exculder in between. This manipulation again puts the colony in its productive strength and swarming instinct is also reduced.

Swarm prevention and control. Prevention and control of swarming is important management practice because strong colonies are essential for good honey production and efficient pollination of crops. Energy of swarming colonies is wasted and most of the time the swarms and parent colonies are liabilities for the commerical beekeeper.

Beekeeper should always provide all comforts to the colony. The colonies should be kept in shade as shade makes the bees to tolerate lesser ventilation and overcrowding to some extent. Ventilation is increased by widening the size of entrance. The brood and super chambers can be raised by about $3 \mathrm{~mm}$ with the help of wooden splinters. But utmost care is needed in the latter manipulation as the space in between the hive parts should not be more and 
it should not allow the foreign bees to enter the hive. Any negligence can induce robbing.

It has been stated earlier that all the bee colonies in an apiary differ with respect to swarming propensity. The apiary records can give an indication about the colony to be used for rearing queens. For making this decision other criteria such as honey gathering capacity and disease resistance should be borne in mind along with low swarming instinct. This means that a beekeeper should always practise a sort of selective breeding.

Bee colonies headed by older queens are more prone to swarming. Efforts to change the queens in early spring are remunerative in reducing swarming.

Overcrowding enhances the swarming tendency. Therefore, enough space. by adding drawn combs or by giving additional comb foundations should be provided so as to keep the bees busy and not allow the colony to fall in imbalance. It should be borne in mind that all categories of workers, i.e. nurse bees, wax producers and foragers, should find enough space to be busy with their jobs and idleness should not be allowed.

Damree method seems to work well when the swarming is most likely to occur. The method necessarily involves the isolation of queen from the brood. The bee colonies are inspected and the frame with queen is set in empty hive body at the place of parent colony. A comb with pollen is added and all other empty raised combs with one or two comb foundations are given in this hive body. All other frames with stores and brood are placed on top of this chamber with an excluder in between. All sealed and unsealed queen cells are destroyed before doing this manipulation. The upper hive body is again examined after 8-10 days and any queen cells raised are destroyed, thereafter no brood of appropriate age would be left for queen rearing. This method is useful in discouraging swarming.

If the bees persist in building queen cells, the best procedure is (a) to divide the colony into two; (b) get a new queen mated; (c) kill the old queen; and (d) unite the two again. In such cases swarming urge is satisfied, colony is requeened and not much of energy is lost.

Strong bee colonies can be stripped off some brood and bees without effecting the output of the colony. Two or three combs can be removed and empty combs or foundations can be given in their place. This helps in keeping a balance in the colony but the disadvantage is that field force is reduced. The brood and bees so removed can be used to boost weak colonies. The strengthening of weak colonies has to be done with proper assessment so that not to overload weak colonies with brood. Practically the same objective can be achieved by changing the places of weak colonies with strong ones where comparatively much field force is lost from populous to weak colonies.

\section{Making colony increase}

In a bee yard new colonies are needed every year for expanding the size of apiary and/or to requeen some colonies which are of low productivity. In all apiaries some colonies are always there which are unprofitable with little 
biological value. It is advisable to replace the queens of such colonies to increase honey production of the apiary. With best management practices, some loss of colonies is expected during hard seasons of winter or summer. These losses are to be made good by the beekeeper by making colony increase. Finally, the beekeeper ma be interested in multiplying the colonies for sale.

Decision on the time of division of colonies is very crucial. It varies from region to region with differences in climate, flora and honey flow seasons. No hard and fast guidelines can be possible. As a general rule, the best time to raise new colonies is when the swarming propensity is expressed by the colony. During this time the mating success of queens is high and the queens also perform better with more number of sperms stored in their spermathecae. It is a golden rule not to weaken parent colonies and maintain their economic value.

Before obtaining the divisions, the best performing colonies are selected for mass queen rearing. Sealed cells with about to emerge queens are used for queening the divisions. For selection of mother colony for queen rearing, the apiary records can be consulted. The colonies which grow in strength and have enough foraging force to avail the flow are good colonies. Colonies which rear more brood and have higher stores should be given due weightage.

Swarming is the natural method of colony increase and swarms can be hived to raise the additional colonies. But wise and experienced beekeeper would not depend on swarming for increasing the number of colonies because this is an unsure method and there can be chances of losing the swarms. He always endeavours to prevent and control swarming, though even with best efforts some swarms would go out which of course are used for making colony increase. The beekeeper would obviously manage the colonies as he wishes to and does not leave the colonies to themselves.

Early in the season, about 2 months before honey flow the colonies can be divided into halves. Such colonies grow weaker since about 40 days will elapse between the raising of emergency queen to the starting of egg laying. Therefore, queenless half is given preferably a new mated queen from mass reared queens in the apiary.

The colonies which can be divided early, grow into productive units in about 2 months. The nucleus colony after Brassica boney extraction can grow into yielding strength by the end of April in warmer plains.

A nucleus can be made from 2 or 3 colonies. In the middle of spring the bee colonies build up $\hat{i}$ strength and each colony can spare 2 brood frames with bees without affecting the performance of parent colony. The bees and brood from 2 or 3 colonies can be put together to form a nucleus. It may be necessary to unite bees obtained from different colonies. The drawback with this type of colony increase is that only young bees remain in the divide. These young bees are not expected to be familiar with the area and foraging picks up slowly. Such nuclei are formed in the evening when bees have stopped days work so that some older bees may not return to their parent colony. The nucleus is given a new queen. 
In some localities colony division can be taken just before the honey flow is over. This is possible in areas where some flora is available for the divides to grow till autumn. The colony. division avails about 7-15 days of honey flow and gather sufficient stores and later avail the minor sources. The queens usually do not mate during the division time because of hot summers. So already mated queens are to be used for the divides. This may also not be possible in areas with hard summer season, because in such areas weak colonies are unable to over summer successfully. The division can even be delayed till the end of honey flow season but in areas where flora is available for the colony to grow into full strength within next 3-4 months.

\section{REFERENCES}

Goyal, N.P. 1978. Performance of $A$. mellifera over $A$. indica as observed in Punjab plains. Indian Bee J. 40(1) : 3-5.

Shah, F.A. and Shah, T.A. 1980. Early life, mating and egg-laying of Apis cerana from Kashmir. Indian Bee J. $42(2): 48$.

Sharma, P.L. 1951. Bee work done in the Punjab (I) up to 1950. Indian Bee J. 13 : 27-35.

Sharma, P.L. 1960. Observations on the swarming and mating habits of the Indian honeybee. Bee Wld 41(5) : $121-25$.

Woyke, J., Ruttner, F. and Koeniger, N. 1972. Reproduction in Apis cerana; mating behaviour. I. Apic Res. $11(3)$ : $141-46$. 


\section{QUEEN REARING AND ARTIFICIAL QUEEN BEE INSEMINATION}

DRONES which are reared from the unfertilized eggs are haploid and carry the genomes of their mother. The males and queen contribute to the heredity of the offspring workers. Under natural conditions a beekeeper cannot exercise control on parentage and drones from the vicinity can take part in fertilizing a queen. But good queens can be reared from better performing colonies so that the hereditary characters contributed by the mother can be improved to a greater extent. In an apiary many queens may be required for requeening and colony divisions. Therefore, mass queen rearing is discussed bere.

\section{Selection of mother stock}

Requeening of some or all the colonies in a n apiary becomes a feature of a nnual management. With some additional effort an element of multiplying a better stock can be introduced. All the colonies in an apiary are not equally superior performers. Beekeeper is concerned with higher honey production but honey production is directly correlated with amount of broad rearing as also the queen's egg-laying capacity, industriousness of workers, swarming and absconding tendency, frugal behaviour and disease resistance. Apiary records for these attributes are essential to select the best colonies for queen rearing. In the absence of records for all these attributes, only the honey yield records of colonies can serve an important criterion for selecting colonies for mass queen rearing. Superior colonies can also be induced to rear drones. Though the mating with these drones cannot be assured yet the chances can be increased by making these colonies to rear more drones.

\section{Biological basis of queen rearing}

Queen bee lays fertilized as well as unfertilized eggs. Both the workers and the queen develop from fertilized eggs. A larva from a fertilized egg can be reared into a worker or a queen. There seems to be no or very little genetic bias in caste determination. Worker and queen larvae are fed on glandular food for the first 2 or 3 days and there is hardly much difference in the quality of food of the 2 castes. Moreover supply of food is more than the requirement. At about the age of three days, there is a shift in food to worker larva, whereas queen larva continues to get the nutritious glandular secretion food. Honey and pollen is mixed in the food of worker larva and also the feeding is progressive or in other words the developing larva is starved to some extent.

Larvae from fertilized egg is plastic for caste determination up to the age of $72 \mathrm{hr}$ but the queens reared from larvae older than $72 \mathrm{hr}$ may develop into intercastes. Diet is the major caste determining factor. Though the better food 
is responsible for higher $\mathrm{JH}$ titre in queen larvae which consequently affects the development of reproductive organs. Feeding of stored royal jelly is also not a perfect food for queen rearing which indicates that the royal jelly has some labile fraction.

A colony rears queens, only when certain favourable conditions are available. The bee colony must be crowded so that the bees feel the necessity of rearing queens under swarming impulse. This condition can be altered in case of queenlessness where the influence of queen or queen cell building and queen rearing is removed. For feeding queen larvae large number of young nurse bees are required because worker bees of the age of 6 to 12/13 days have well developed and active food glands. Food glands of worker bees remain actively secretory if they get a continuous supply of pollen. Therefore, continuous income of pollen and nectar also creates favourable conditions for queen rearing. The queen rearing is possible if these prerequisites a re naturally available or are artificially created by manipulations.

\section{Methods of queen rearing}

Queen rearing is inhibited by pheromone secreted by the mandibular glands of the queen and spread over the queen's body to be licked by the workers. Certain level of this pheromone would be required to suppress the queen rearing urge. The level of the queen pheromone available to the workers may be reduced when the colony population is very high. Such overcrowded and populous colonies rear queen cells under swarming instinct. The reduced anount of queen pheromone is a vailable to the workers in a colony when the queen is old and is exhausting. The bees feel the necessity of superseding the old, failing queen and queen cells are raised on the face of the comb but are fewer in number. The queen can be reared from the eggs or the larvae. Failing queen, herself lays eggs in the supersedual cells raised by the workers. In case of sudden loss of queen, the queen cells are built under emergency impulse and these queens are reared from worker cells with larvae of certain age. Therefore, they are built on the face of the comb and the queens vary in development stages.

Queen rearing is triggered off when any of the above 3 conditions are available or artificially created. When few queens are required, a beekeeper can remove the queen from a colony and few emergency queens are raised by the bees. Modified swarm box method used for swarm control can be profitably used without removing the queen. As discussed under Damree method of swarm prevention, the queen with a brood comb, honey and pollen comb and remaining frames with empty combs or comb foundation is restricted to the lower chamber. All other frames with sealed and unsealed brood are kept in upper chamber with a queen excluder in between the two. The second super if already there can be placed in between the 2 chambers. Few queen cells are built above the queen excluder and the sealed queen cells can be carefully removed from the base and the emerging queens can be used.

Alley developed a queen rearing method where the comb with young larvae is cut into small strips. Larvae in alternate cells are destroyed so that 
enough space is available for raising queen cells. The cells of desired la rvae are shaved off and the pieces of comb are attached to the bar on comb so that the desired larvae hang with their openings facing downwards.

In Miller method 2 or 3 in. wide strips of foundation with V-shaped top are attached to the top bar of a frame. This prepared frame with many strips with space in between is given in the brood nest. Comb is built on these foundation strips and queen lays eggs. When this is achieved the cells of desired larvae are shaved off and the frame is transferred to cell builder colony prepared few hours earlier. The cell builder is a queenless colony with sufficient young nurse bees. Combs with young brood should preferably be removed with the queen so that the queens are reared only from the brood in prepared frame from breeder colony.

Doolittle or grafting method is most commonly used for mass queen rearing. This method requires the grafting of young larvae in queen cell cups. The cup can be of plastic or made from pure bees wax with inside diameter of 8-12 mm for Apis mellifera and 6-9 mm for Apis cerana indica. Single forming stick can be used for preparing queen cups when only few queens are to be raised. For preparing la rge number of cups, the single forming stick is not practicable and multiple forming sticks are useful. The multiple forming stick is a bar made by attaching 10-15 cell forming sticks of same length to a thick strip of wood with a spacing of about $2.5 \mathrm{~cm}$ from centre to centre. Wax is melted in a tray on thermostatically controlled hot plate or in a waterjacketed tray. The wax for attaching the cups to the bars is melted just above the melting point. The cell bar is laid over the pan of wax for attaching the cell cups to bars. Wax is put over the upper surface and the sticks with the cell cups are rested on the bar and more wax is put along the sides and between the cups. The sticks are beld in position till the wax has cooled. The forming sticks are then lifted off by putting an even pressure on the ends of the bar. A strong, well-fed and superior-performing colony is selected for obtaining larvae for grafting. The bees are shaken off and the frame containing sufficient young larvae is taken to grafting room. A temperature of $24^{\circ} \mathrm{C}$ and relative humidity of about $50 \%$ is suitable. Grafting in the open may lead to drying and desiccation of grafted larvae if the temperature and humidity conditions are not closer to the requirements and the larvae get chilled if the atmospheric temperature is low. A bright lamp is placed so that light shines directly on the bottom of the comb cells when the comb containing the la rvae to be transferred is little tilted towards the operator.

For grafting, a grafting, needle with flat upward bent is used (Fig.44). For more extensive queen rearing, the use of automatic grafting needle is advisable. Automatic grafting needle has retractable tongue which is extended about 1.5 $\mathrm{mm}$ before it is slipped side ways under the larva. This grafting tool also transfers sufficient royal jelly along with the larva and is very successful in dry grafting. While placing the larva at the base of the queen cell cup, the lever of the grafting needle is released so that the tongue retracts back and larva is left on the base of the cup. Less experienced operator may need priming of cell cups with royal jelly to achieve better results. 
Queen cell builders. There are several methods for starting the queen cells but swarm box is a common method. Little before the newly grafted queen cells are given, the box is stocked with $2.5 \mathrm{~kg}$ of bees taken from active brood nest. Two pollen combs are given on either side of the frame with grafts. Combs with stored honey are given to the cell starter and continuous supply of sugar syrup is useful. A useful modification of this queenless swarm box is profitably used. The 'modified swarm box' is a cell starter in which the bees are confined above the two-storey colony for 24-36 hr while cells are being started. Queen is confined beneath the excluder in the bottom body with sealed brood and empty combs and combs with young brood are moved to the upper body. A full depth body is prepared by putting 2 pollen combs, 2 or 3 combs with honey stores and division feeder full of sugar syrup. The frame with grafted cell cups is placed in between the 2 combs with pollen stores. All the young bees from above the queen excluder, that is, second hive body, is shaken off in the prepared starter body below which a 8-mesh hardware screen is fastened. The combs with young brood are returned to the second hive body. The bees cannot move from the second to the third hive body and bees are confined there for $24-36 \mathrm{hr}$ by which time the cells are drawn and queen larvae are being reared. The screen is then removed and the hive is reduced to 2 body with an excluder in between the two. The cells are sealed and removed a day before emergence and put in incubator for emergence.

Cell builder colonies can be repeatedly used for starting the cells. The cells once started can be given to cell finisher colonies for completion (Fig.45). The cell finisher colony can be a strong 2-storey queen right colony. Queen is confined to the lower body by an excluder and cells are completed in the upper body.

Double grafting is also practised to ensure good quality queens. In double grafting the first grafts are removed after the cells have been started and second graft is given in the same cell cup. This is to avoid starving of the graft and the second graft will get food supply immediately.

\section{Artificial mating}

Artificial queen bee insemination technique is now available and mating in the open can be bypassed. There are distinct advantages of the technique. By artificial queen bee insemination method the parentage can be controlled. The virgin queens can be inseminated with the semen from desired drones and hence the technique is the only method for bee breeding but for commercial beekeeping the artificially inseminated queens are less suitable. The queen insemination can be possible at any time of the day and even in bad weather. But the disadvantage is that the operator should be experienced to achieve high success. Success of instrumental insemination also depends on the simplicity and reliability of insemination apparatus. Mackensen and Roberts were the first to develop it in 1948 which met these requirements. During the same year, Laidlaw also developed an artificial insemination equipment. Mackensen and Roberts' apparatus is more widely used.because of its 

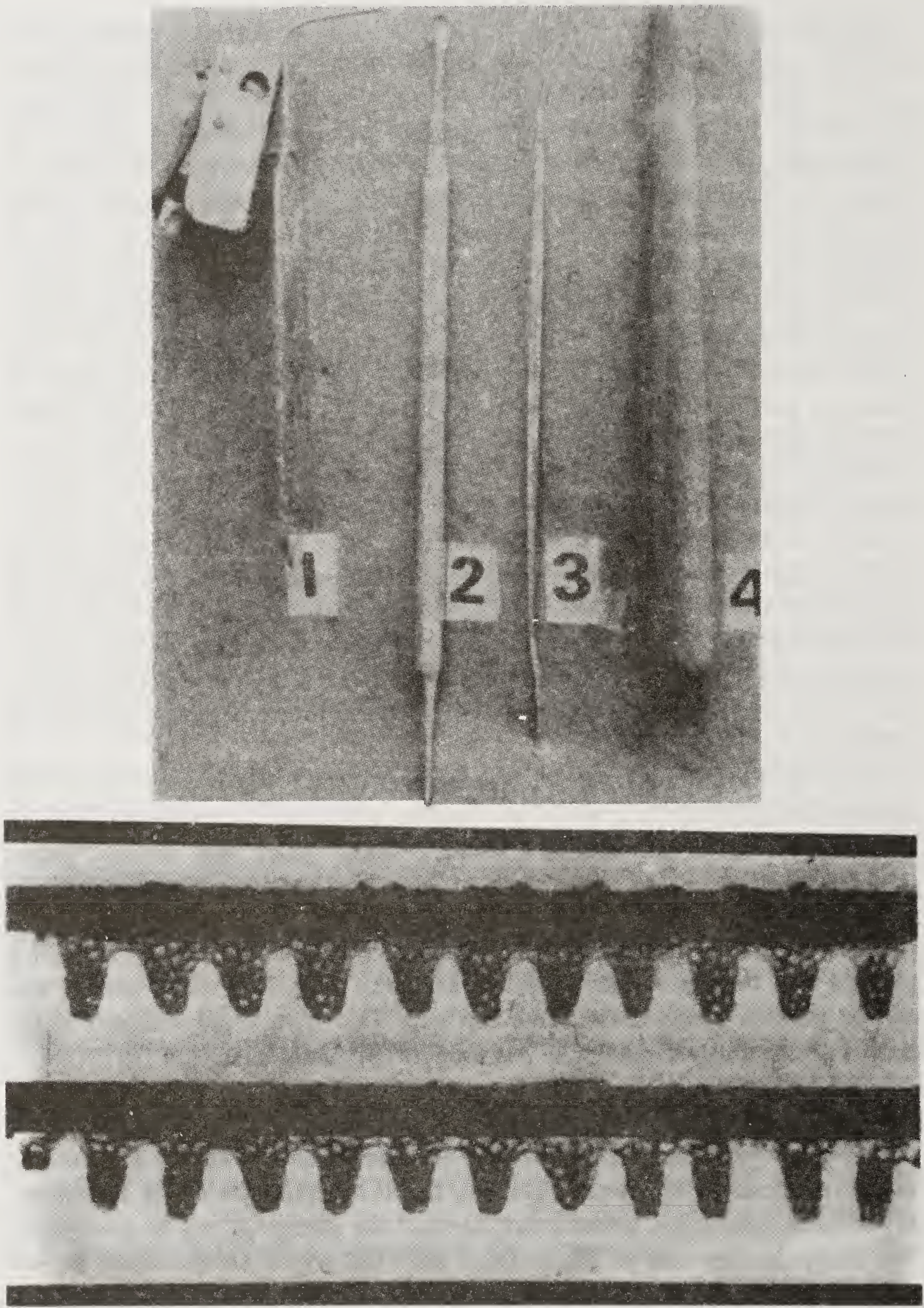

Fig. 44. Grafting needles $(1,2,3)$ and cell furming stick used in Doolittle method of queen rearing.

Fig. 45. Sealed and about to be sealed queen cells obtained in mass queen rearing by grafting method.

simple construction and easy handling. Several improvements have since been made in this apparatus. The two types of apparatus basically differ as follows: 
Laidlaw insemination equipment

1. Queen manipulator has a heavy circular base whose bottom surface is smooth and slides easily on the glass stage of a microscope for positioning the queen in relation to the syringe.

2. Queen holder consists of 2 vertical surfaces. Pieces of foam are glued to each of these surfaces between which the queen is clamped. The fixed surface is recessed into a block to make a closed anaesthetization chamber about the queen when she is clamped in position.

3. Syringe manipulatur is operated by rack and pinion movement and allows up and down movement to an adjusted angle. String and ventral hooks are inounted by chunks on vertical rack and pinion, which are mounted on horizontal racks and pinions to either side of the centrally located queen holder.
Mackensen and Roberts' equipment

It consists of a stand with a plate and 2 vertical round posts. Queen block is fastened to the stand by its main component. The gas tube passes through the main component and opens into a disc in front of which queen holder is attached.

Queen holder is a tube of transparent plexiglas with an inside diameter of $6.6 \mathrm{~mm}$ at one end. At the narrow end there are 3 longiludinal grooves on the inside surface to facilitate escape of $\mathrm{CO}_{2}$ gas around the queen abdomen. Queen is mounted into the queen holder with the help of a short tube. A stopper is attached to the end of the gas tube which fits into the queen holder, so that $\mathrm{CO}_{2}$ may pass out through groove openings and keeps the queen in position.

Syringe is moved up and down with hand for positioning to insert into the reproductive system of the queen. Sting and ventral hooks are mounted to permit finger tip control for smooth movement in all directions.

With both the apparatuses the operation of insemination consists of the same steps but details of how these steps are accomplished differ. Glass in place of plastic syringe tips are now developed. Glass tips can be drawn with substantially smaller diameters than plastic tips. Because of smaller diameters, the tips should be more suitable for inseminating $A$. cerana indica queens. Glass tips have smoother surface and, therefore, injure the queen less frequently. They are also easier to sterilize but are easily broken.

Insemination. There are some important considerations for the success in queen bee insemination. (i) Queens reared from different breeder colonies differ with respect to the ease of insemination. (ii) Large-sized queens with long tapering abdomens are easy to inseminate than short, stubby queens. (iii) Virgin queens of the age of about one week a re better as it is easy to locate their vaginal orifice but in older queens the operation becomes difficult.

Preparing the queen for artificial insemination is important. Queen is made to move into the tube similar to the queen holder. When she reaches the narrow opening end she backs up and queen holder is quickly placed with the open end of the tube. As she reaches the narrow end of the queen holder the stopper through which $\mathrm{CO}_{2}$ is flowing is pushed in so that the last segments of the abdomen protrude. As soon as the queen is quiet, 2 hooks are put in position to open the abdominal end. Syringe is prepared by filling the syringe tip with solution to serve as a liquid plunger. Sodium chloride $(0.9 \%)$ is satisfactory but Ringer's solution is good. These avoid the mortality of the sperms. Air in the syringe is avoided because it nullifies the purpose of the liquid plunger. 
Drones vary in the ease with which they are induced to ejaculate and also in the amount of semen produced. All the drones caught at the hive entrance do not evert and deliver semen, some evert so violently that the semen is lost or sometimes even penis bursts. For quicker collection of semen the drones are caught from the entrance in the afternoon and caged in the cages. The drone holding cages are held in normal bee colonies. The cage has queen excluder sheet on one side and hardware screen on the other and it allows nurse bees to feed the drones. These drones are used for semen collection after few days so that all are sexually mature. Before using the drones for semen collection, they are advantageously made to fly in drone tlying cages, so that they get excited. Drone is held from the head and thora $x$ between the thumb and index finger and with little tickling it everts. The operator needs experience to collect semen without mixing the mucus. The tip of the syringe is applied to the semen and is drawn by retracting plunger of the syringe. The semen should be quickly collected after eversion. The operator should avoid to collect every bit of the semen on the penis because in that case there are chances of drawing the mucus into the syringe. As soon as the syringe tip is filled, a small amount of physiological saline is drawn into the syringe tip. Washing technique for semen collection involves scrapping of semen and mucus in physiological diluent in a semen washing funnel and a collecting tube. The mixture of semen, mucus and diluent is centrifuged at $2,500 \mathrm{rpm}$ for $10 \mathrm{~min}$ to separate semen from mucus and diluent.

For the insemination of semen, the syringe tip is posed above the vaginal opening. It is inserted into the dorsal part of the vagina and the valvefold is pushed ventrally until the tip of syringe has passed beyond the valvefold. In natural mating, the queen herself lowers the valvefold. If the column of semen does not begin to move by moving the plunger, then the syringe is not in median oviduct and must be withdrawn for a nother attempt. Number of sperms stored in the spermatheca increases with the increase in the quantity of semen injected. Eight microlitres of semen is adequate. Semen given in 2 inseminations with equal amount is better since more number of sperms are stored as compared to single insemination.

Inseminated queens are kept in cages and held in nursery colonies. They start laying eggs after 2-4 days but $\mathrm{CO}_{2}$ treatment reduces this period.

Woyke (1973) explored the possibility of instrumental insemination of Apis cerana indica queens. He found that semen was difficult to be separated from mucus and average semen was only $0.16 \mathrm{~mm}^{3}$ per drone as compared to $1 \mathrm{~mm}^{3}$ in Apis mellifêra. Concentration and activity of spermatozoa is also lower in Apis cerana indica. Semen from $40-60$ drones is necessary for effective insemination of $A$. cerana indica queen. Crosses between the two species have also been attempted but could not be successful. Hardly any work has beell conducted on Indian honeybee on the aspects discussed in this chapter. The books by Laidlaw (1979) and Ruttner (1976) on this subject are comprehensive and are valuable readings. 


\section{REFERENCES}

Laidlaw. Harry. H. (Jr). 1979. Contemporary Queen Rearing. Dadạnt and Sons, Hainilton, Illinois, $199 \mathrm{pp}$.

Ruttner, F.D. 1976. The Instrumental Insemination of the Queen Bee. Apimondia International Beekeeping Technology and Economy Institute, Bucharest, Romania.

Woyke, J. 1973. Instrumental insemination of Apis cerana indica queens. J. apic. Res. 12(3) : 151 58. 


\section{BEE PASTURAGE}

HONEYBEEs have closed link with the flora because adults and young ones live solely on nectar and pollens. Usefulness of a flora depends upon the quantity of food and energy harvested and the energy requirement of bees. Nectar is secreted by nectaries and is usually a reward for the visitors bringing about poliination. In general, the quantity of nectar secreted is directly related to the pollination requirements of the crop. Honey is made by bees from the nectar collected from floral and extrafloral nectaries. Sometimes honeydew is also important source in certain localities, but the well being of bees is greatly dependant on the value of the flora. For the selection of the apiary site it is essential to know the plants which provide nectar or pollen to bees. Data on different aspects can be gathered for couple of years to establish the potentials of an a rea for beekeeping. Scale colony provides useful information. Weight of the scale colony is regularly recorded and the changes in weight are correlated with the flowering plants which are being visited by bees and also the weather conditions. Flowers present nectar and pollen during specific time of the day, therefore, bee activity on the flora should be carefully recorded. Recording the bee activity at different day hours should give useful information. Melissopalynological studies are essential to ensure as to which plants are availed by bees. Pollen analysis of honey samples taken at different time of the year and comparing with reference slides give the exact information about the tloral sources for bees in a vicinity

Bee flora should be studied from different angles to find out the value of bee forage though the total nectar production per flower is important. Some flowers secrete nectar only for one day and few others for short time and still there are flowers like Schefflera wallichiana which continue nectar secretion for about a fortnight. The time for which a nectar plant blossoms is another important point determining the value of flora. In some forages the duration between the start and end of flowering is very short, whereas in others like Brassica spp, there is a succession of flowering and it lasts for about a month. Trees present larger number of flowers as compared to bushes, shrubs and crop plants unless the latte $i$ are growing in large continuous areas. Concentration of nectâr sugar gives an objective measure. Total sugars per flower per day is the sugar value which is normally estimated for such studies. Sugar value is the number of $\mathrm{mg}$ of sugar secreted by one flower over a period of $24 \mathrm{hr}$. However, total quantity of nectar produced and the a mount available to or harvested by bees give valuable information.

\section{Nectar-sugar concentration}

Nectar concentration in most bee forages varies between $20-50 \%$ but may be as low as $6 \%$ in Bombax ceiba L. to $15 \%$ in pear and as high as $79 \%$ in 
silver oak (Grevillea robusta). Nectar and sugar concentration (\%) has been worked out for some flora in India. For example, Grevillea robusta had $79 \%$ sugars in the nectar (Deodikar et al., 1957), 23 plants including Tecoma grandiflora had $14 \%$, peach and pear $70 \%$, Brassica juncea $52 \%$, Barberis $48 \%$, some citrus spp. 40-44\%, Sapindus detergens $40 \%$, Plectranthus $38 \%$, Cidrella cerata 36\% (Sharma, 1958); Carvia callosa 35\% (Phadke, 1964); Thelepaepale ixiocephala 35-64\% (Phadke, 1965); Impatiens balsamina 1625\% (Singh and Sharma, 1972), Nephelium litchi 61-78\% (Nair, 1983), Plectranthus 26-54\% (Gupta et al., 1984); Woodfordia floribunda 10-12\% (Mishra et al., 1987), Brassica campestris var. toria 38.5-53.5\% (Kapil and Brar, 1971) and onion 59-75.5\% (Rao and Lazar, 1980). Gupta et al. (1984) found that there were considerable differences in the amount of nectar sugar production in the flowers of different cultivars of cauliflower and in the attraction of bees to them. Average nectar sugar contents varied from 0.035 to $0.150 \mathrm{mg} / \mathrm{fl}$ ower $/ 24 \mathrm{hr}$. On the basis of such studies honey potentials per unit area are estimated for cultivated crop/fruit plants. For wild flora the density per unit area is estimated by sampling and honey potentials of the flora in the area are worked out. Honey potentials of a forage are only estimates but it serves as a useful guide. Honey potentials of a forage are liable to change. This is happening fast in developing agriculture in India where changes in land-use patterns have been very frequent. Under extensive agriculture vast waste lands are cleared for cultivation and this reduced the wild flora. Land may be put to urbanization or industrialization causing reduction in cultivated and wild bee flora. There are introductions and extension of cultivation of new crops like sunflower, safflower and other oilseed crops and this has substantially changed the scenario with regard to beekeeping potentials. There are many agricutural practices which affect the bee flora. Mechanized agriculture reduces the weed plants which may be serving as bee forage. The use of weedicides is another agricultural practice which reduced the weed forage for bees.

The nectar yielding plants contributing to nectar/honey flow are specific to different areas and they have definite micro-regional habitats. Even in rich floral areas continuous succession of nectar yielding plants throughout the year is lacking. In some localities there is single surplus honey flow and in good a reas 2 surplus flows may be available. In north-western hills of Himachal Pradesh and Jammu and Kashmir, the lower and mid hills present spring, early summer flow and in areas like Kashmir and parts of Himachal Pradesh, there is rich flow from Plectranthus in autumn. Bees face protracted dearth period in winters and only subsistence flora is available in rainy season but heavy downpours are hazardous to bees. In north Indian and Gangetic plains, major flora of Brassica is available from September through early February. This build up and surplus flow is followed by spring and summer surplus honey flow from Eucalyptus, Dalbergia sissoo, and other trees and berseem is availed by bees till May. Hard summers are also no flora availability period but some weeds and crops present subsistence forage in rainy season. In Western Ghats and south India, there is medium to major flora available 
from October to May and important sources being jamun, hirda, carvi, soapnut, rubber plant, Schefflera, etc. but June to September is a dearth period. Therefore, for beekeeping sub-tropics may have an inactive period of 1 or 2 months. In tropics it is dry season or excessive rainfall and in hills it is winter which are troublesome to bees. Surplus flow season may vary from 1 or 2 and rarely 3 in a year.

Beekeeper, to maximize his honey crop, should have a thorough knowledge of the floral cycle, onset of major honey flow and dearth periods. The bee colonies should be managed in a way so as to have maximum foraging strength to avail major flow and economical or minimum strength in dearth period.

\section{Nectar composition}

Nectar is a solution and total solids in nectar are mostly sugars. There are only few exceptions where lipids are present in nectar. Chromatographic studies help to know the sugars in nectar. Monosaccharides, glucose, fructose and disaccharide, sucrose, are the common sugars in nectar. In general, flowers with tubular corolla secrete sucrose dominant nectar. In open flowers, such as Brassica, only glucose, fructose and sucrose are present. Bee's preference to nectar is also governed by the sugar balance and the nectars with equal amount of glucose, fructose and sucrose are preferred by bees. Minute amounts of other substances such as amino acids, minerals, essential oils, organic acids and other components usually comprise less than $0.03 \%$ of total dry weight. Essential oils impart characteristic a roma to nectar and honey and bees are attracted by this aroma to flower nectar. Solid particles in the form of pollen grains, yeast cells, fungal spores and bacteria can be found in small amounts.

Attempts have been made by Indian scientists to gather information on the nectar composition of bee flora. Sucrose, fructose and glucose (28:1:1) make up to $60 \%$ of the total solids of Thunbergia grandiflora nectar (Nair et al., 1962). They also detected small amounts of aspartic acid, alanine, glycine, serine and valine by paper chromatography. Moringa pterigosperma Gaertn. nectar contained $0.90 \%$ of reducing and $11.81 \%$ of non-reducing sugars (Nair and Singh, 1974). Wakhle et al. (1981): analysed nectars from 4 species; nectar of Carvia callosa contained fructose, glucose, maltose, raffinose and an unidentified sugar; nectar of Thelepaepale ixiocephala had only fructose, glucose and sucrose, whereas nectars of Schefflera roxburghii and Grevillia robusta had only fructose and glucose. Only these 2 sugars were observed by Mishra et al. (1987) in Woodfordia floribunda nectar. Soapnut (Sapindus emerginatus) nectar had $85.5 \%$ sucrose, and $7.25 \%$ each glucose and fructose (Reddi et al., 1980). Sibag and Kapil (1983) analysed the nectars of 44 plants visited by Apis florea and Apis dorsata. Nectar of Tecoma stans and all 11 cruciferous plants, Althea rosea, Prunus persica, P. domestica and Petunia alba contained glucose dominated sugars, and sucrose and fructose were in very small fractions. Bahadur et al. (1986) analysed nectar of 103 plants from 100 species and revealed that 54 plants had 3 sugars, viz., sucrose (S), 
glucose $(G)$ and fructose (F). In addition to these, 7 plants had 4 or more sugars, 6 having $S+G+F+1$ unknown sugar, one having $S+G+F+2$ unknown sugars. Forty plants had 2 sugars $(29: S+G ; 3: S+F ; 8: G+F)$ and 2 had only one each $(1: G ; 1: S)$. In the nectar of these plants, 24 had dominant sugar as sucrose, 7 had $S+G, 2$ had $G$, and one had $G+F$ and there was no plant having either $S+F$ or $F$ dominant sugar. Six plants had balanced $S+G+F$ sugars, 3 plants had $S+G$ and there was no plant having. $G+F$ balanced sugars. In 90 plants amino acid was present, whereas in 15 plants, the amount was double than the remaining ones.

\section{Factors affecting nectar secretion}

Honey flow from the same plant is not the same under varying weather, soil and vegetation habitat conditions. The nectar secretion in a plant is the function of specific features of the forage and other external factors. Factors related to a plant species are age of the flowers and the cultivar or varieties. In Woodfordia floribunda Salisb, the flowers continued to secrete nectar for 3 days (Mishra et al., 1987); it was maximum on second day and minimum on first day of flower opening. The differences in nectar secretion have also been found in many plant species and differences with age of the flowers and cultivars have been reported in peach (Mishra et al., 1985) and cauliflower (Gupta et al., 1984) in India. Nectar secretion in flowers after opening is expected to be correlated with the degree of receptiblity of the stigma. Fertilization in flowers is also known to activate a feed back mechanism to switch off nectar secretion. After certain period of flower opening there is reduction in amount of nectar sugars. This happens because of reabsorption of nectar. Reabsorption only of nectar sugars takes place and not of water. Therefore, the reabsorption at the end of nectar secretion leads to lowered nectar sugar concentration. The total amount of nectar secretion over a period by a flower is more when it is periodically removed tha $n$ in case of its nonremoval by insects. Besides these, growth regulators have also been found to affect nectar volume and nectar sugars. The effect of GA3 was more pronounced in mustard and cauliflower than with other growth regulators (Mishra and Sharma, 1988).

Sunlight and temperature. Sunlight has a direct bearing on photosynthesis. Photosynthesis produces carbohydrates which are secreted in nectar. Effect of sunlight and conse:quently of photosynthesis may not be immediate because stored carbohydrates do make good but ultimate effect is there. Temperature has direct relationship with nectar secretion. For every plant species there is a specific threshold temperature at which the nectar secretion is started and it increases when the temperature is optimum. This is the range of temperature at which enzymes responsible for nectar secretion are activated. On the other hand very high air temperature may result into water stress in plants and the. water stress causes more water loss than the uptake. The imbalance results into lowered nectar secretion through reduced sugar transport in the conducting tissues.

Relative humidity. Nectar is hygroscopic in nature and for this reason 
atmospheric humidity is inversely linked to nectar sugar concentration. After secretion nectar sugar concentration changes and attains an equilibrium with the moisture in the air. Water is always lost from nectar unless the relative humidity is near $100 \%$. High relative humidity causing reduction in sugar concentration can affect the attractiveness of the source to bees. Conversely higher sugar concentration at lower relative humidity can affect the nectar column in the tubular flowers and bees may be unable to reach and imbibe the nectar. Water loss in the plant is also a function of relative humidity as alșo of air temperature.

Soil. Optimum soil moisture is essential for good plant growth. With soil water as a limiting factor the number of flowers is reduced and nectar secretion is also adversely affected. Balanced nutrient level in soil which supports good plant growth also favours nectar production. Phosphorus and potassium increase nectar production but high level of phosphorus reduces it. A balance between the 2 elements should be beneficial. Excessive application of nitrogen causes abnormal vegetative growth and comparatively lesser number of flowers are produced. Some of the bee forages have been briefly discussed in this chapter.

\section{BEE FLORA OF INDLA}

\section{Avenue, amenity and timber trees}

Eucalyptus spp. (Fam.: Myrtaceae). These are evergreen trees and are indigenous to Australia. In Australia most species are bushes and shrubs but fortunately in India Eucalyptus spp. attain gigantic size. Different species and even varieties flower during different parts of the year but main bloom is available in spring. Eucalyptus plantations have expanded very fast on road side, canals, even waste lands and thus presenting vast potentials to bees. Honey is light amber coloured and granulation is fairly quick.

Hirad (Terminialia chebula Retz; Fam.: Combretaceae). Hirad is distributed in the Western Ghats and in submountainous regions. The fruits have medicinal value and also a source of dyes and tannins. It is a major flora in beekeeping areas of Maharashtra (Chaubal and Deodikar, 1965; Deodikar and Thakur, 1953). It flowers in April to June. Hirad honey is composed of $17 \%$ water, $35 \%$ glucose, $40-41 \%$ fructose, sucrose, maltose, melezitose, ash and it also contàins calcium, phosphorus, iron, magnesium, sodium, potassium and silicon. Tartaric, citric, malic, succinic acids are also present (Narayana, 1970; Phadke, 1962; Phadke et al., 1970). Honey is light yellow coloured; granulation is slow and has characteristic pungent aroma and tastes akin to fruit tannins. Terminalia arjuna (Rob.) Wight and Arn. has been widely planted in forests and as avenue plantation. It is also a nectar and pollen source but details of value as bee forage have not been worked out. T. bellerica (Gaertn.) Roxb. has also both nectar and pollen forage but no data on nectar and honey is a vailable.

Jamun (Syzygium cumini Skeels; Fam.: Myrtaceae). Jamun (Fig.46) is widely planted avenue-cum-fruit tree and naturalized as forests in many parts 


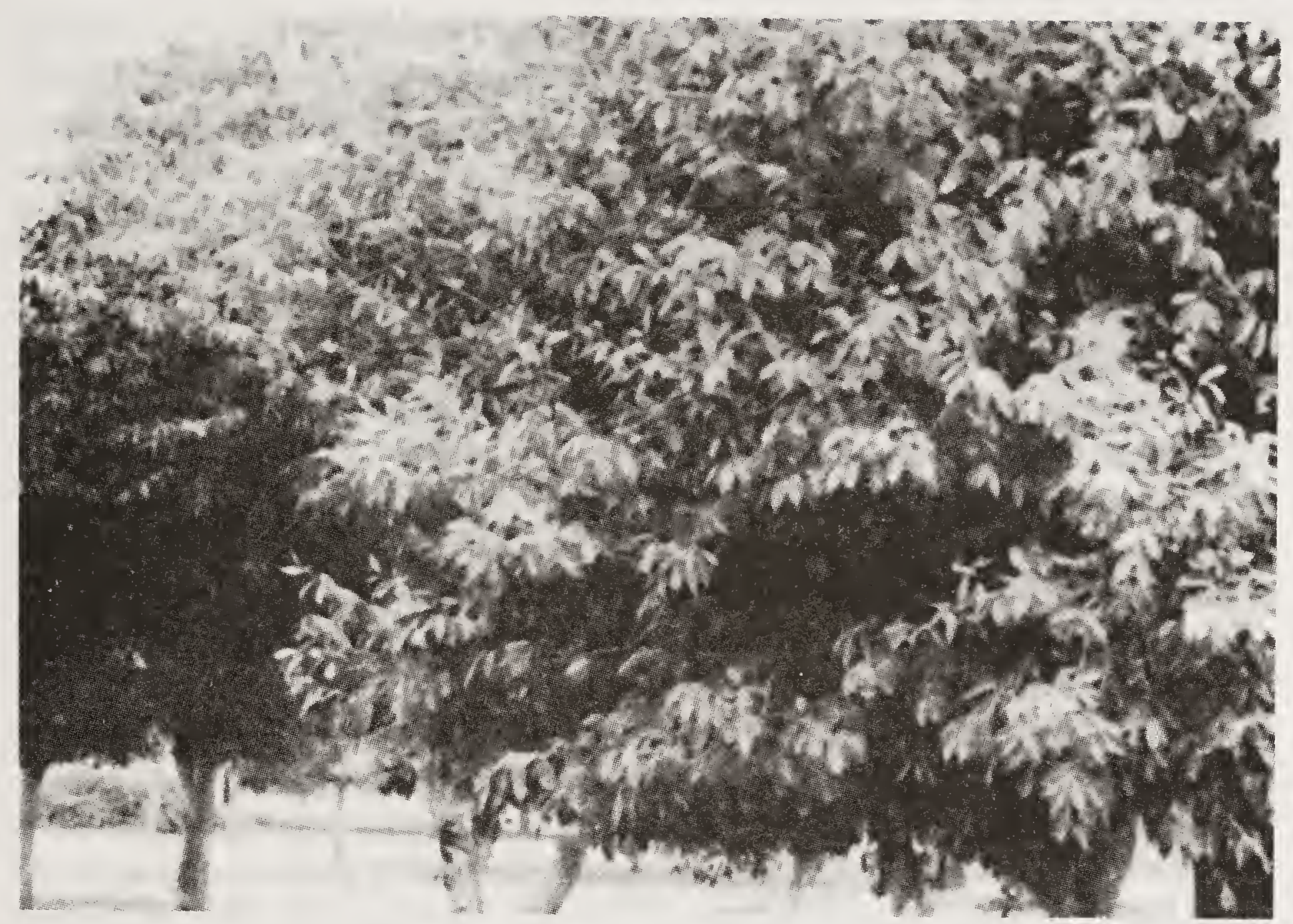

Fig. 46. Jamun, a surplus honey flora.

of India. It is a predominant flora of Western Ghats. It is reported to be a major flora in Bihar (Naim and Phadke, 1976), Maharashtra (Chaubal and Deodikar, 1965; Chaubal and Kotmire, 1980; Deodikar and Thakar, 1953), Punjab (Chaudhary, 1977), Tamil Nadu (Chandran and Shah, 1974) and Uttar Pradesh (Kohli, 1958). Its flowers are dirty white and bloom in April-May. The honey flow extends over a period of 2 or 3 weeks. Nectar-sugar concentration is very high up to $72 \%$ but may be as low as $9 \%$ (Satyanarayana, 1975). Jamun is also a pollen source. Chemical composition of honey has been given by Narayana (1970); Rajebhonsale and Kapandis (1970); Phadke et al. (1970). Fructose is high (43.30\%) and glucose is $32.26 \%$, sucrose, maltose, reffinose and melezitose are present in jamun honey. Protein $(0.656 \%)$, dextrin $(1.55 \%)$, ash $(0.182 \%)$ and riboflavin, ascorbic acid, thiamine and niacin are also present in honey. It is light reddish-brown and has characteristic taste of jamun fruit. The honey does not granulate for years.

Karanj (Pongamia pinnata (L. Pierre); Fam.: Leguminosae). Karanj grows well in humid tropical area. $P$. glabra is grown as avenue and shade tree in drier climate. Leaves are used as fodder. It blooms in April-May and both nectar and pollen are availed from karanj. Data on nectar production, honey characteristics and honey potentials are not available but it is considered to be good flora by the beekeepers.

Moulsari (Mimusops elegni L.; Fam.: Sapotaceae). Moulsari is evergreen tree with whitish flowers. It has good nectar flow in May-June in Bihar (Naim and Phadke, 1976), Maharashtra. (Subramaniam, 1979) and also in Uttar Pradesh. Bees also collect pollen from this flora. No information on nectar and honey from moulsari is available. 
Phalsa (Grewia asiatica L.; Fam.: Tiliaceae). Phalsa shrub is grown for its fruits. It blooms from April to August and yields nectar to bees. The extent of its cultivation is less. G. oppositifolia Roxb. is a medium-sized tree which is planted for lopping its foliage for fodder, for its best fibre for ropes and for timber. It blooms in April-May and is a nectar source to bees. These species of Grewia a re only minor sources.

Rubber (Hevea brasiliensis Muell. Arg.; Fam.: Euphorbiaceae). Rubber plant is deciduous tree with male and female flowers on the same inflorescence. Nectar is available to bees only from the extra-floral nectaries at the base of young buds. The nectar flow is there for about 2 weeks when leaves are young. Rubber is a major flora in Kerala where large plantations are grown (Devadason, 1971-1972). Honey potential is estimated to be $3 \mathrm{~kg}$ per tree (Mathew, 1975). Rubber honey is clear straw coloured.

Schefflera wallichina Harms. (Fam.: Araliaceac). It grows as a strangler or small tree in forests or cardamom estates of Coorg area of Karnataka. Schefflera blooms in April-June and is a rich nectar source. Most honey in Coorg is obtained from this source. Pollen availability to bees is very low.

Shisham (Dalbergia sissoo DC.; Fam.: Leguminosae). Shisham's habitat is very varied, from lower hills to dry plains; normally planted on banks of canals or roadside as shade tree (Fig. 47). This is a source of valuable timber especially for furniture. Pale-yellowish flowers are put forth in April. Corolla is tubular but narrow tube has nectar well up to the reach of bees. Wind blows flower from branches and nectar availability is adversely affected. It is a major nectar source for bees in many states especially Himachal Pradesh, Punjab, Haryana and Uttar Pradesh. Shisham honey is dark amber with moisture

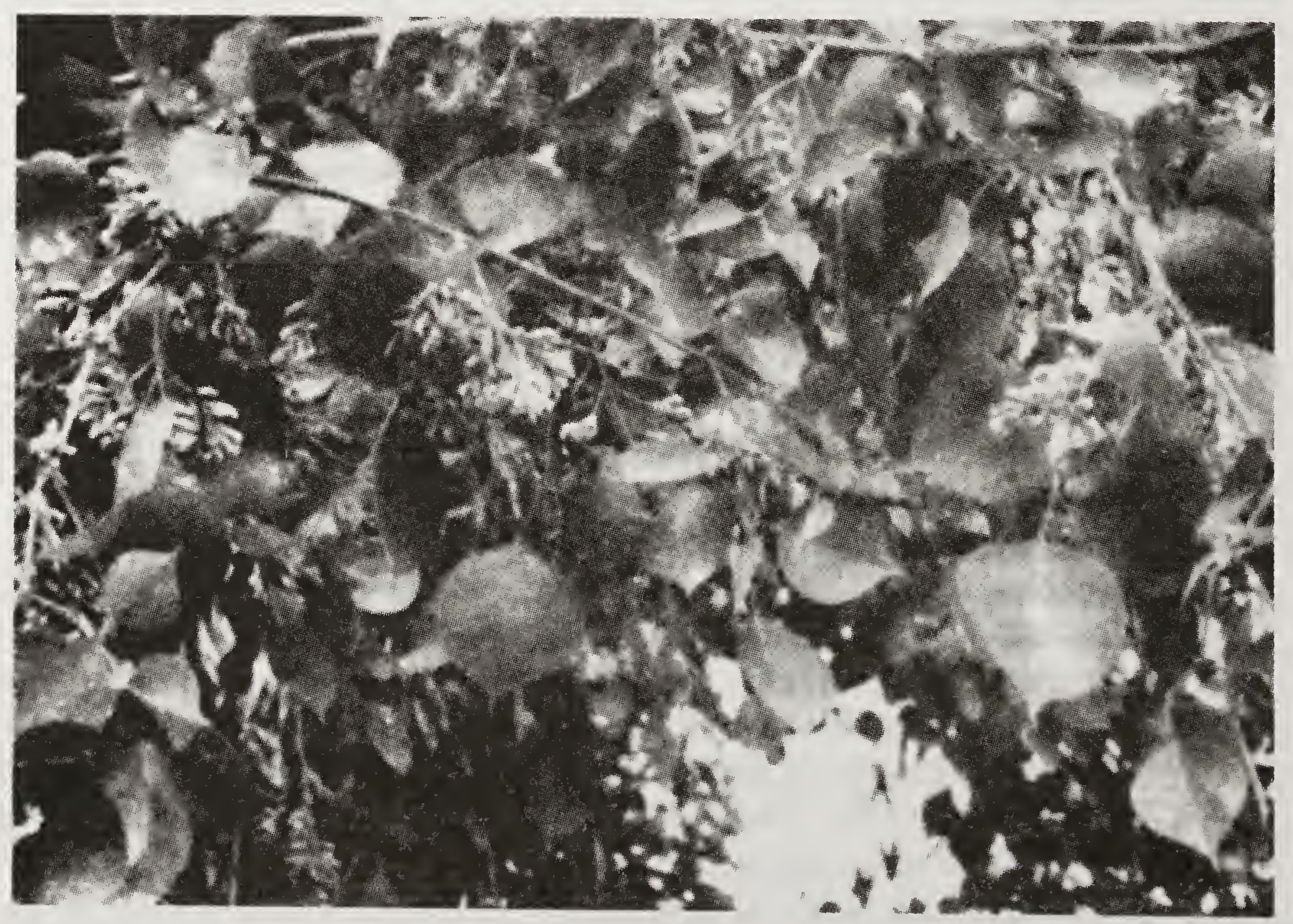

Fig. 47. Dalbergia sissoo in full bloom. 
$18.75 \%$, glucose $34.6 \%$, fructose $39.1 \%$, sucrose $1.04 \%$ and ash $0.18 \%$. Honey flavour is strong and not attractive.

Silver oak (Grevillea robusta A. Cunn. ex R. Br; Fam.: Proteaceae). Silver oak is planted in coffee plantations and also as shade and avenue tree. It profusely flowers and is an important nectar source (Deodikar et al., 1957; Wakhle et al., 1981), and nectar secretion is abundant with $17-79 \%$ nectar concentration. Honey is reddish-black with prominent flavour and it granulates rapidly.

Soapnut (Sapindus spp.; Fam.: Spindanceae). Soapnut (Fig.48) is an avenue and forest tree; fruits are used as substitute to soap. $S$. emerginatus Vabl is a species found in Andhra Pradesh, Karnataka, Orissa and Tamil Nadu (Krishnaswamy, 1970). The species flowers in October-December. It gives 20-25\% of total honey yield in some parts of Andhra Pradesh. S. emerginatus nectar has $85.5 \%$ sucrose and $7.25 \%$ glucose and fructose (Reddi et al., 1980).

Tamarind (Tamarindus indica L.; Fam.: Leguminosae). Tamarind is a large evergeen shade tree cultivated in many parts of India for pods which are used in curries. The tree has many other uses like fuel, timber, etc. It blooms in April-July and is a good nectar and minor pollen source in South India. Honey is rich golden and has sour flavour.

Toon (Toona ciliata M. Roem.; Fam.: Meliaceae). Toon (Fig.49) grows as timber and avenue tree in lower hills and plains of northern India especially in moist soil. It is also lopped for fodder but is not to the liking of cattle. Toon is a major nectar source in Himachal Pradesh (Singh, 1948), Kashmir (Saraf, 1972), Punjab (Chaudhary, 1977) and Uttar Pradesh (Kohli, 1958; Ramesh, 1980). It is a minor source of pollen. Large number of trees have recently been cut and floral source has declined. Nectar sugar concentration varies from 26 to $72 \%$ in freshly opened to $48 \mathrm{hr}$ old flowers. Average nectar sugar value is $2.38 \mathrm{mg} /$ flower/day and nectar is secreted for 4 days. Honey is light amber in colour with pronounced flavour. Normally its boney is mixed with Dalbergia sissoo boney and is obtained in May.

Whayati (Thelepeaple ixiocephala (Benth.) Bremk; Fam.: Acanthaceae). Whayati is a tree of moist forests of Western Ghats of Maharashtra and Karnataka. Whayati flowers after every 8 years. It blooms in NovemberJanuary and is a major nectar source. Sugar concentration of nectar is 35 $46 \%$ (Phadke, 1965). Honey contains $38 \%$ glucose and $39 \%$ fructose; sucrose, maltose, raffinose and melezitose are present. Sodium, potassium, calcium, magnesium, iron, phosphorus and silicon are contained in whayati honey. It is light yellow and granules rapidly but granulation is uniform (Chaubal and Deodikar, 1965).

There are many other avenue and forest trees which are good source of nectar and pollen but their number is small and at best serve as subsistence sources. These trees a re bottle brush (Callistemon lanceolatus DC.), pride of India (Lagerstroemia indica L.), drum stick (Moringa oleifera Lam.), Indian laburnum (Cassia spp. Fig 52), puna (Ehretia acuminata B.), siris (Albizzia 
spp.), willows (Salyx spp.) and chestnuts (Aesculus sp., Castanea sp. (Figs. 50, 51).

\section{Fruits}

Banana (Musa spp.; Fam.: Musaceae). Perennial herb, stem formed by leaf petioles. Flowers are large and monoecious. Musa spp. flowers throughout the year and is a medium to good source of nectar which has $25-30 \%$ sugar concentration. Banana flowers are also visited by bees for pollen which is in abundance. Banana plantations are common in many states of India.

Cashew (Anacardium occidentale L.; Fam.: Anacardiaceae). Cashew is cultivated in South India. It is evergreen tree, flowers pink, small and fragrant. Devadason (1971) has advocated migratory beekeeping to avail cashew flow: It is also a pollen source; value of the flora and honey characteristics are not known.

Citrus spp. (Fam.: Rutaceae). These are $C$. aurantifolia (Christm) Swingle (Fig.53); C. grandis (L.) Osbeck; C. limon (L.) Burm.; C. paradisi Macfad.; $C$. reticulata Blanco; and $C$. sinensis (L) Osb. These citrus species flower during February-March. Nectar production and nectar sugar concentration is
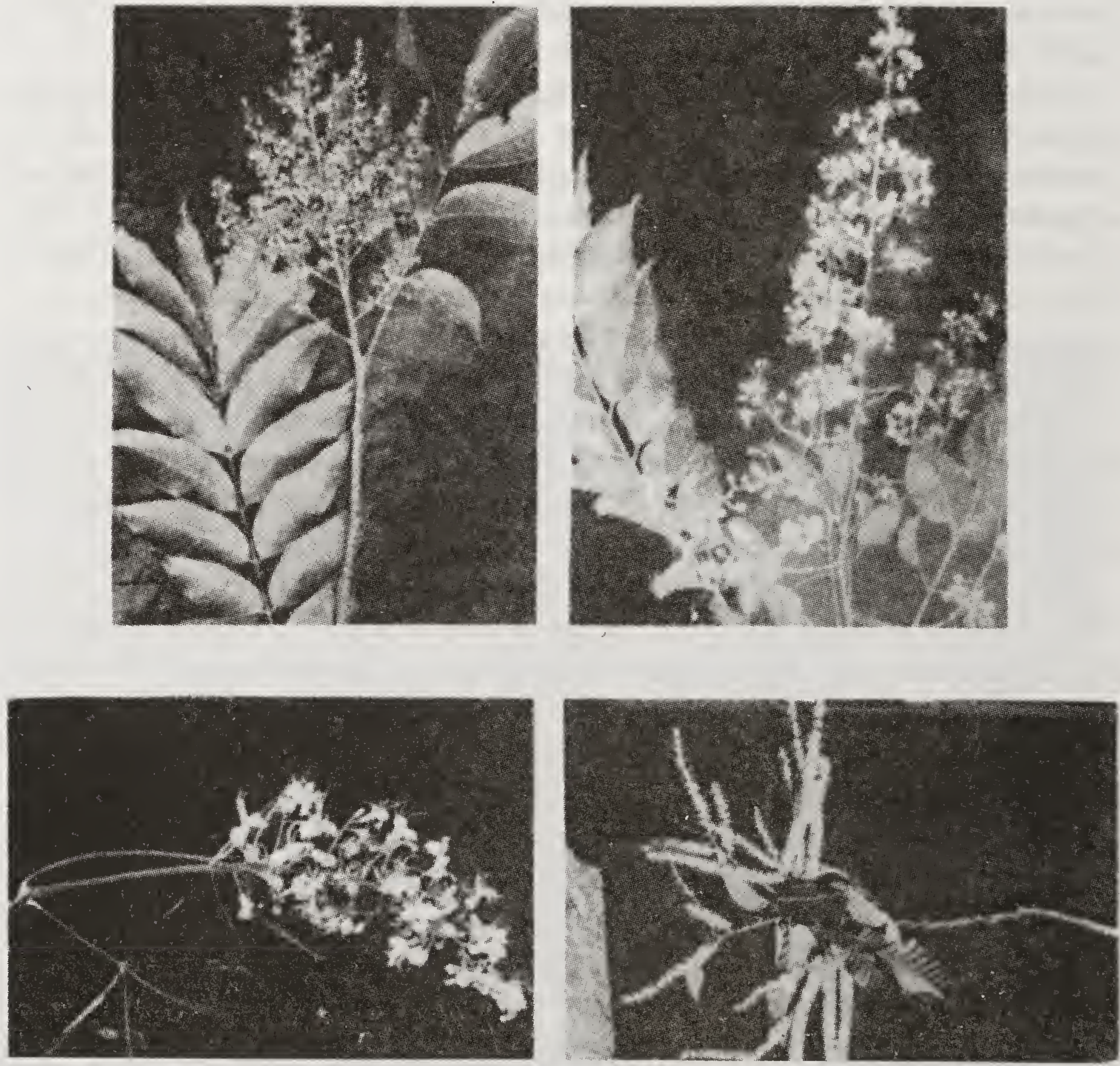

Figs. 48-51. 48. Soap nut, a nectar source. 49. Toon (Toona ciliata), rich nectar source. 50. Sweet chestnut grows as forest tree in hills. 51. Horse chestnut, nectar bee flora of hills. 
medium. Citrus spp. also serve as pollen source. Citrus honey has delicate flavour. In India Citrus mostly serves as a build up flora and surplus is not extracted anywhere, though large areas are under citrus and it is widely distributed.

Coconut (Cocos nucifera L.; Fam.: Palmae). It is grown in coastal regions. Flowers are small, monoecious, both male and female flowers have nectaries. It blooms in May-June and bees collect abundant pollen from staminate flowers in spathes.

Jujube (Ziziphus mauritiana Lam.; Fam.: Rhamnaceae). Indian jujube is cultivated in tropical parts of India, advantageously below 600 M.S.L. It tolerates severe heat and is drought resistant. It flowers during July to October and flowering is very protracted. The flora gives surplus honey when the colonies are strong but bees get nectar source when there is no other flora. Some pollen is also availed and, therefore, it is very useful forage for bees. The jujube honey is yellow-brown with very sweet flavour.

Litchi (Litchi chinensis Sonner; Fam.: Sapindaceae). Litchi bas become very popular in sub-mountainous regions for expensive fruits. It blooms in March and is a rich source of nectar to bees (Naim and Phadke, 1976; Chaudhary, 1977; Chaturvedi, 1969; Nair, 1981). Sugar concentration of nectar is high. Juice from damaged fruits is also availed by bees. Litchi honey is light golden coloured with very pleasing aroma.

Pome and stone fruits. Apple, pear, plum, peach, apricot, cherry, almond and their closely allied wild species are included in this category. They flower from February to April and bees gather both nectar and pollen. These fruit trees have local importance and have good build up sources before surplus honey flow season. Pear nectar is very low in sugar concentration. Therefore, it is normally avoided in favour of other competing flora. Surplus honey is not gathered from these cultivated fruit trees. But wild cherry, Prunus puddum Roxb. flowers in October to November when no other flora is available in mid and lower hills of Himachal Pradesh. On an average a flower secretes $35 \mu$ l nectar for 4 days with $3.47 \mathrm{mg}$ nectar sugar per flower. Nectar sugar concentration varies from 12 to $18 \%$. Chromatographic separation revealed glucose, fructose, sucrose and one unidentified sugar in the ratio of 39.6, 40.7, 12.3 and 7.5 (Reddy and Gupta, 1987). This flora gives mild. honey extraction in some localities. Honey is light with medium flavour and granulates slowly.

\section{Cultivated and wild bushes, shrubs and field crops}

Bramble (Rubus spp.; Fam.: Rosaceae). It starts flowering from middle of January and continues till mid March in hills. Nectar sugar concentration of $R$. ellipticus is $65-71 \%$. Mean sugar value for the nectar of this species is $2400 \mu \mathrm{g}$ per flower per $24 \mathrm{hr}$ (Gupta and Thakur, 1987):

Plectranthus rugosus Wall (Fam.: Labiateae). It is a wild bush in billy areas of Himachal Pradesh and Kashmir. It flowers profusely in August to October. Plectranthus is a very rich nectar source, though pollen is also collected by bees. Nectar' sugar concentration varies from 26 to $54 \%$. 


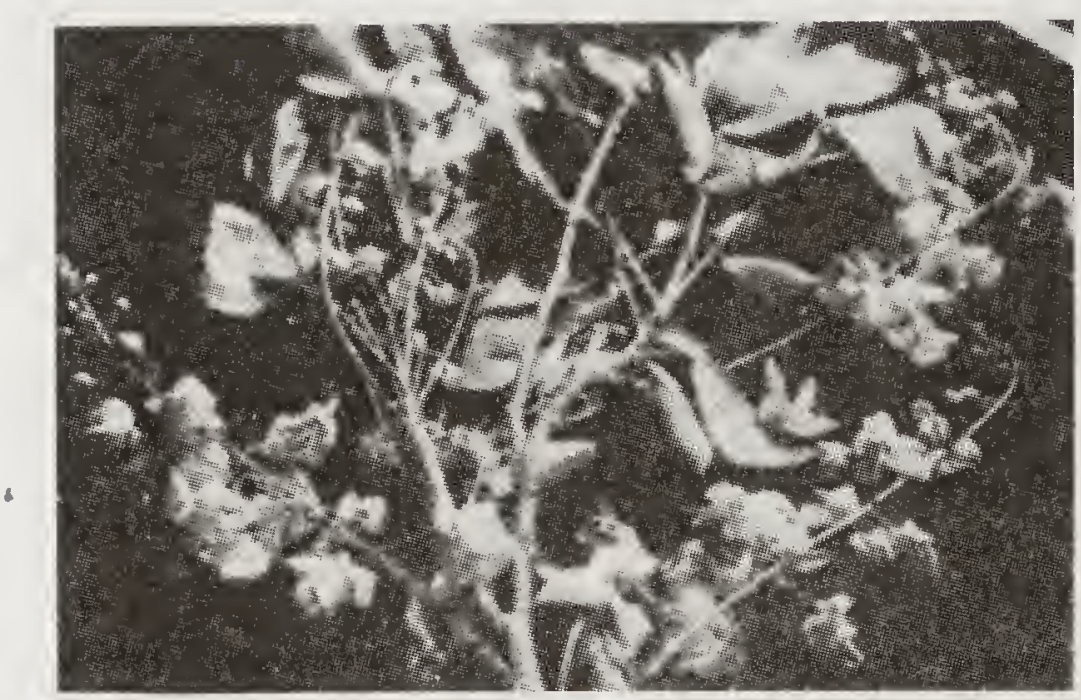

Fig. 52. Indian laburnum (Cassia sp.) in bloom.

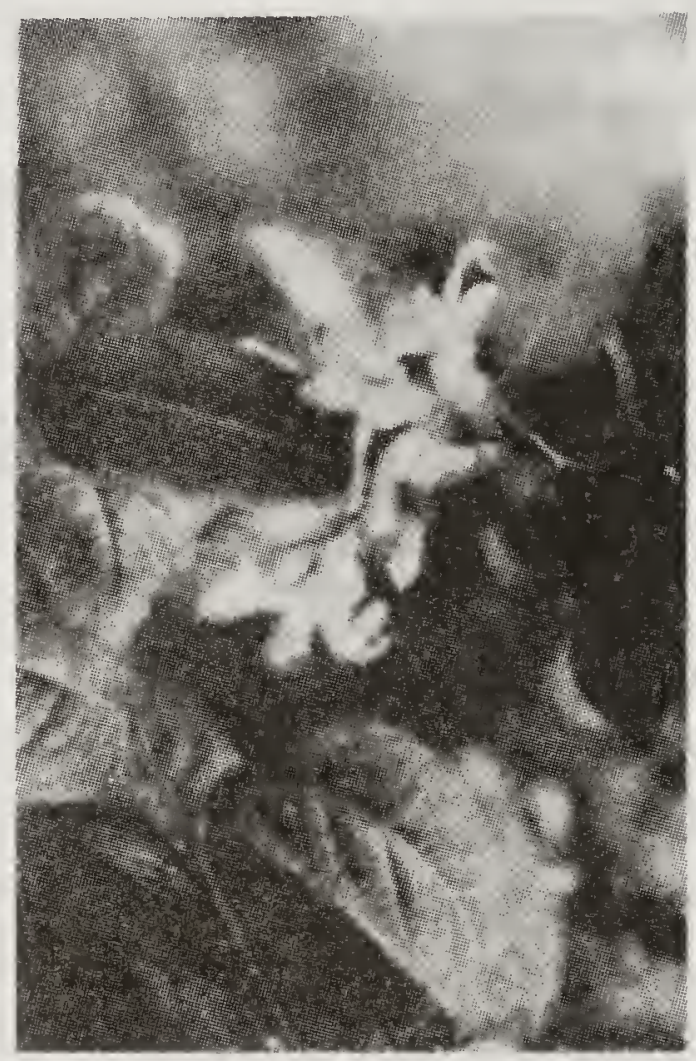

Fig. 53. Flowering branch of Citrus sp.

Fig. 55. Bees foraging on apple flower. s, a bee flora
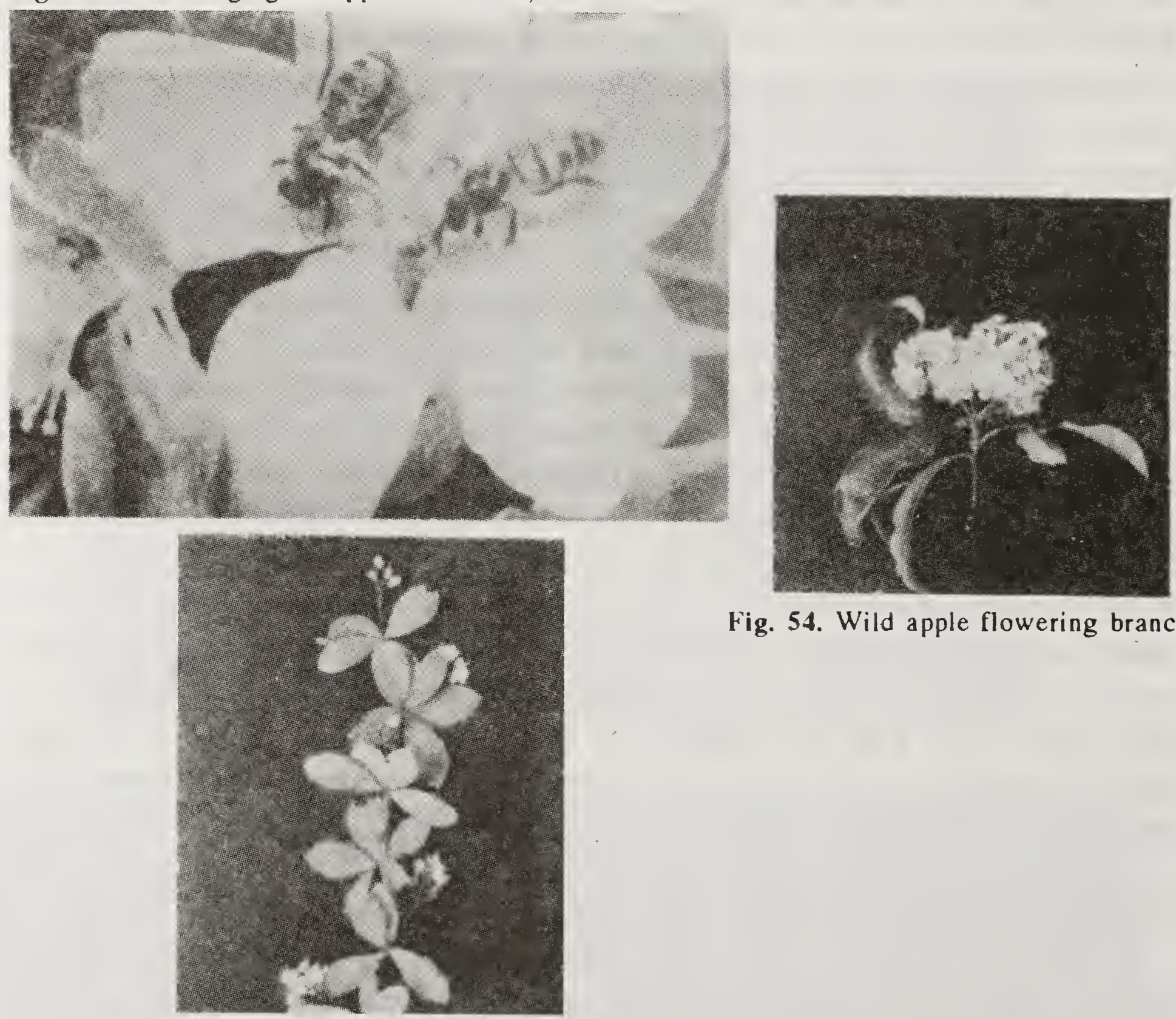

Fig. 54. Wild apple flowering branch.

Fig. 56. Berberis, a bee flora in lower and mid-hills.

Beekeepers migrate their colonies to avail the flora and bring back their colonies to lower hills before winter. Singh and Singh (1971) reported $P$. rugosus to be the major honey plant of Kashmir but Atwal and Goyal (1974) reported that Apis mellifera did not avail the rich honey source in autumn. 
Later Gupta et al. (1984) confirmed the foraging on $P$. rugosus and surplus honey extraction from mellifera colonies. In good years a n average of 30-40 $\mathrm{kg}$ honey per colony is obtained from this rich flora.

Vitex negundo L. (Fam.: Verbenaceae). The shrubs sometimes grow into small tree (Fig. 57). It is common in sub-Himalayan tract, also grown as bedge and as an ornamental up to an altitude of 1,500 m. It blooms in AprilMay (June in hills) and bees visit the flowers mainly for nectar. Nectar sugar value is $690 \mu \mathrm{g} /$ flower/day with nectar sugar concentration of $32 \%$.

Alfalfa, Lucerne (Medicago sativa L.; Fam.: Leguminosae). Lucerne is a fodder crop cultivated in irrigated areas, especially in north India. It is rated as medium source of nectar (Chaubal and Kotmire, 1980). It flowers in August-September. Nectar sugar concentration has been reported to vary from 14 to $60 \%$ by different workers in different countries. Honey potentials are very high in seed crop. Lucerne honey contains $22-35 \%$ glucose, $34-41 \%$ fructose, $2-7 \%$ sucrose and other sugars are maltose, isomaltose, trehalose, gentiobiose, raffinose, melezitose and tura nose. Whitish to light-amber coloured honey granulates rapidly but granulation is fine. No data on the value of this flora is available from India.

Coffee (Coffea arabica, C. robusta.; Fam.: Rubiaceae). Extensive coffee plantations in Karnataka and Tamil Nadu provide intensive nectar flow but flowering lasts for about a week only. It flowers in February-March and nectar secretion mainly depends on soil moisture which is greatly reduced by drought. Sugar concentration varies from 30 to $40 \%$. Pollen grains a re heavy and sticky and bees do collect some pollen, though not a major source.

Cotton (Gossypium spp.; Fam.: Malvaceae). Several species of cotton are grown all over India. They are sown at different times of the year and put forth blossom over a period of about 4 months in each locality. Most species are visited by bees for pollen and little nectar is available in the extrafloral nectaries. Cotton bloom is not visited by bees in case some other flora is available in the locality.

Cruciferous oil seeds (Brassica spp.; Fam.: Cruciferae). Brassica spp. are important source of edible oil in India, especially whole of north India. These oil seed crops are grown in extensive areas. They start flowering from October and continue till mid February. The depleted colonies in rainy season and autumn dearth period build up quickly on early unirrigated crops. The colonies are ready to avail the mainflow from December to February. Surplus honey is obtained in January-February. Bee also collect enough pollen. Brassica honey is yellowish-white and granulates very quickly. Sometimes the stored honey granulates in combs itself which cannot be extracted but has to be left for own consumption of the colony. Honey also bas some pungent flavour and the degree depends on the variety and species.

Egyptian clover (Trifolium alexandrinum L.; Fam.: Leguminusae. Egyptian clover is a popular fodder crop. After taking 4 or 5 cuttings the crop is allowed in the fields as seed crop. Some flowering appear in between the cuttings but seed crop serves as a major source of surplus honey (Naim and Phadke, 1976; Atwal et al., 1970). It blooms in April-Miay and late varieties 

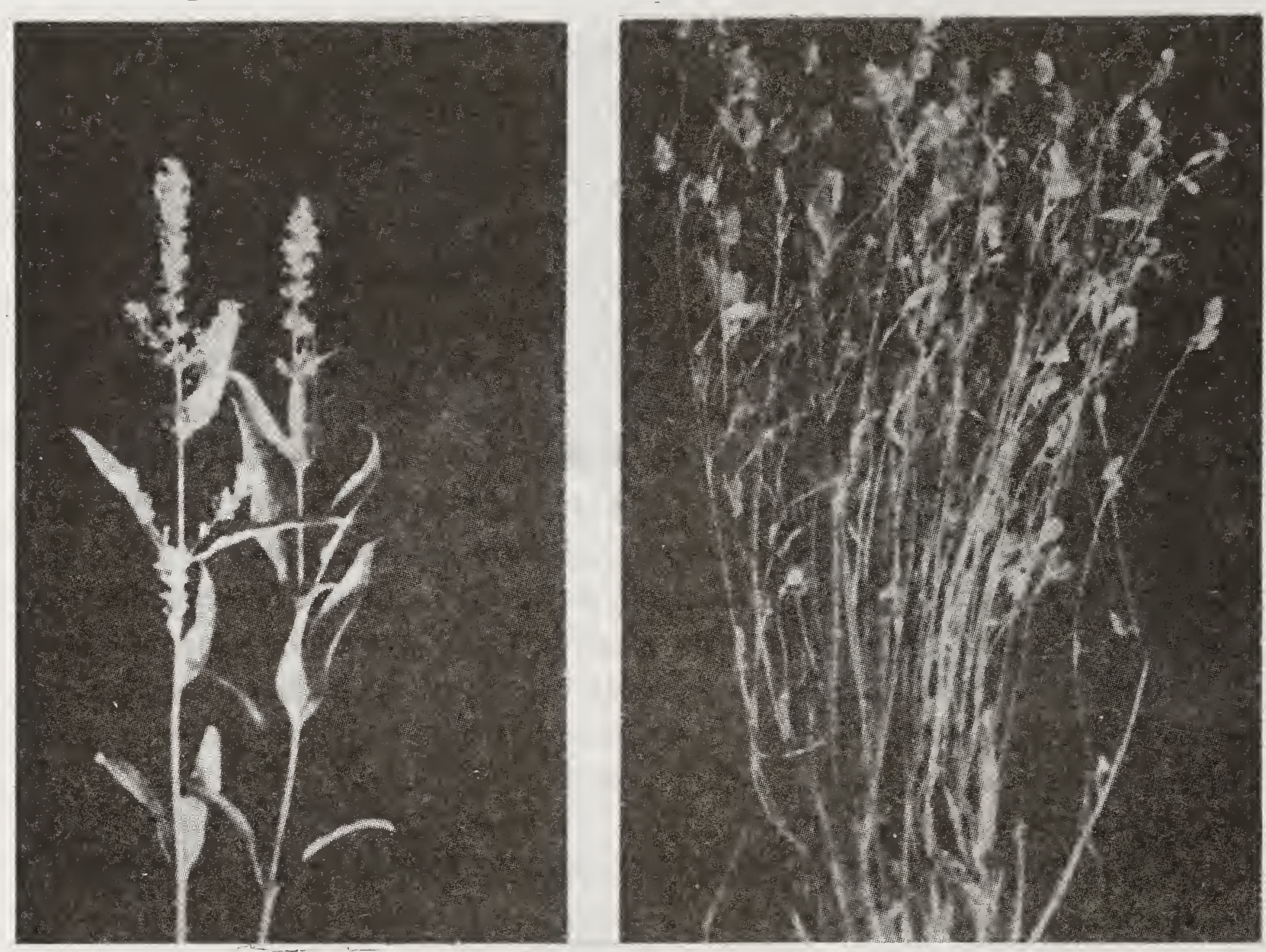

Fig. 57. Vitex sp., a shurb planted as hedge or at the border, serves as bee forage.

Fig. 58. Berseem plant in flowering, a surplus honey flora.

even extend up to mid June. Nectar sugar concentration is medium. Egyptian clover honey has low water content and contains about $71 \%$ of reducing sugars. Sodium, calcium, potassium, magnesium, iron, copper, manganese, and phosphorus are present in honey. Its granulation is slow. In north Indian plains an average of $15-20 \mathrm{~kg}$ honey is obtained per Apis mellifera colony from Egyptian clover. White clover (T. pratense L.) is flora in hills (Fig.59).

Maize (Zea mays L.; Fam.: Graminae). Maize is mainly grown for fodder in summer and autumn but in some areas this also serves as buman food. Oil from maize is considered better than animal fats for cooking. The crop produces large tassels which produce abundant dry pollen. Debiscense takes place in the morning and the pollen falls down or blown off in about $2 \mathrm{hr}$. Maize pollen is poor in nutrition but is a valuable source since it flowers when bardly any other flora is available. It is considered to be medium source of pollen.

Niger (Guizotia abyssinica Cass.; Fam.: Compositae). It is cultivated oilseed crop. Niger blooms in September-October. It is a major source of nectar in Maharashtra (Chaubal and Kotmire, 1980), and now its cultivation is extending fast. Nectar sugar concentration is medium and boney yield is moderate. It is also a minor source of pollen.

Sesamum (Sesamum indicum L.; Fam.: Pedaliaceae). Sesamum is an oilseed crop and seeds are also eaten raw of drink made from seeds. Oilseed cake is a good fodder too. The crop flowers in July-August. White with slight purple shade flowers have nectaries and extrafloral nectaries on the base of 

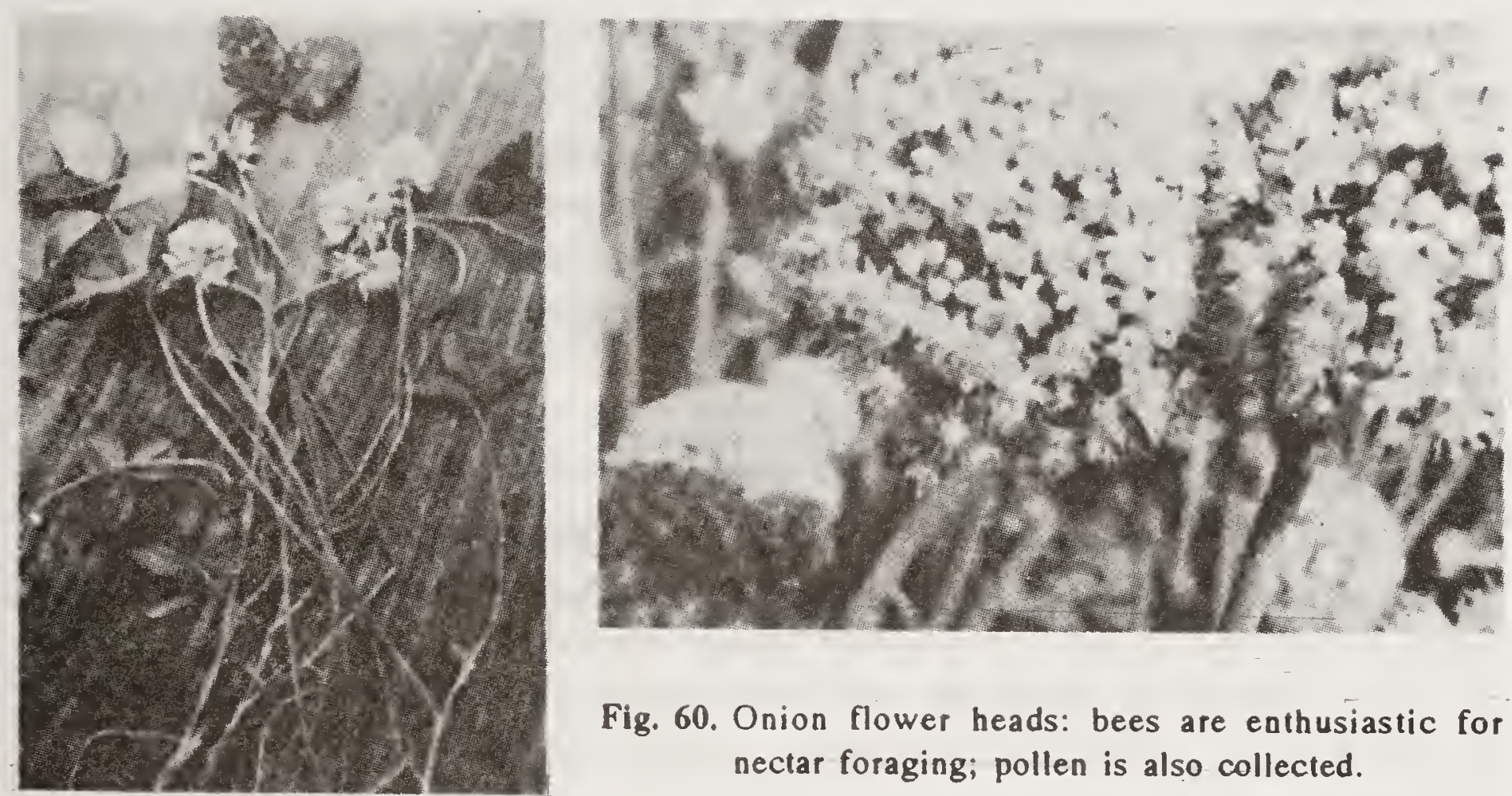

Fig. 60. Onion flower heads: bees are enthusiastic for nectar foraging; pollen is also collected.

Fig. 59. White clover plant, a rich nectar source.

flowers. Sesamum is an important nectar source in areas where crop is grown. It is also a major source of pollen. Sugar concentration is medium $(38 \%)$. Honey is light coloured, clear and granulates slowly.

Sunflower (Helianthus annuus L.; Fam.: Compositae). Sunflower was only a n ornamental but recently it has become popular as an oilseed crop in warm climates. More than one crop in a year can be ráised.' It does not tolerate damp soils and high rainfall. Nectar sugar coneentration is $33-60 \%$ varying with cultivars. Sunflower is a minor to medium source of nectar but major source of pollen. The honey contains $31-42 \%$ glucose, $34-41 \%$ fructose and $0-7 \%$ sucrose. Honey is yellow or golden and since it contains high amount of glucose, the granulation is rapid.

\section{Vegetables}

Generally; vegetables are minor source of pollen and nectar because their small plots are scattered over large areas. Many vegetables are grown for their leaves, stems, corns etc. and seed production is there in small areas. However, there are some crops like umbelliferous crops and cucurbits which serve the cause of bees and are important. Cruciferous vegetables are grown extensively all over India but are not allowed to put forth blossoms except in seed crops. They yield both nectar and pollen from December to March.

Carrot (Dacus carota L.); coriander (Coriandrum sativum L.) and fennel (Foeniculum vulgare L.). Their flowers are favourably visited by bees more for nectar but also obtain pollen in the absence of better sources. They flower from February to May. Because of small plots these serve as only minor flora.

More than a dozen species of cucurbits are grown in patches throughout India and they bloom almost throughout the year except in winter where the winters are severe. Flowering period spreads over a long time but the cucurbit field does not provide enough flowers for bees. They supply both nectar and 
pollen but only few crops are profitably visited by bees. Moreover, the pollen grains are large sized and not availed by bees. However, bumble bees and some solitary bees do visit and pollinate cucurbit crops.

Onion (Allium cepa L.). Ordinarily it is not allowed to flower but large fields left for seed production have the blossoms in May-June. Flowers produce lot of concentrated nectar. It is an insect pollinated crop and bees also collect sticky pollen (Fig.60).

\section{Ornamentals}

There are many ornamentals which are visited by bees for nectar or pollen. But the number of ornamental plants in a locality is too few and as such are of little significance as bee forage. However, these may flower when no other sources are available and prove useful to bees. Following is the list of ornamentals, with their phenology, which are visited by bees:

\begin{tabular}{|c|c|c|c|}
\hline Name & Family & Reward & Month of blooming \\
\hline \multicolumn{4}{|l|}{ Annuals: } \\
\hline Ageratum contyzoides L. & Compositae & $\mathrm{P}$ & vii-viii \\
\hline Althea rosea (av. & Malvaceae & $\mathrm{N}+\mathrm{P}$ & $i v-v$ \\
\hline Aster thomsoni C..B. Clarke & Compositae & $\mathrm{N}+\mathrm{P}$ & $i x-x$ \\
\hline Centaurea cyanus L. & Compositae & $N+P$ & ii-iv \\
\hline Cosmos sulphureus Cav. & Compositae & $N+P$ & $i x-x$ \\
\hline Gaillardia sp. & Compositae & $N+P$ & $i v-v$ \\
\hline Portulaca grandiflora Hook. & Portulacaeae & $\mathrm{P}$ & v-viii \\
\hline Solidago longifolia Schrad & Compositae & $N+P$ & $i x-x$ \\
\hline $\begin{array}{l}\text { Zinnia spp. } \\
\text { Perennials: }\end{array}$ & Compositae & $\mathrm{P}$ & vii-ix \\
\hline $\begin{array}{l}\text { Antigonon leptopus } \\
\text { Hoók. \& Arn. }\end{array}$ & Polygonaceae & $\mathrm{N}+\mathrm{P}$ & v-viii \\
\hline Lonicera sempervirens L. & Caprifoliaceae & $\mathrm{P}$ & iii-vii \\
\hline Quisqualis indica $\mathrm{L}$. & Combretaceae & $\mathrm{N}$ & $v-i x$ \\
\hline
\end{tabular}

\section{REFERENCES}

Atwal, A.S.. Bains, S.S. and Singh, B. 1970. Bee flora for four species of Apis at Ludhiana. Indian J. Ent. 32(4) : 330-34.

Atwal, A.S. and Croyal, N.P. 1974. Apis mellifera turns indifferent to shain (Plectranthus rugosus). Everyday Sci. 19(2) : 25-26. .

Bahadur, B., Chaturvedi, A. and Swami, N.R. 1986. Nectar types in Indian plants. Proc. Indian Acad. Sci (Pl. Sci.) $96(1): 41-48$.

C.handran, K. and Shah, F.A. 1974. Beekeeping in Kodai hills (Tamil Nadu). Indian Bee J. 36(1-4) : 1-8.

Chaturvedi, P.L. 1969. A tip for migratory beekeepers of Kunao region. Indian Bee J. $31: 48-51$.

Chaubal, P.D. and Deodikar, G.B. 1965. Morphological chàracterisation of pollen grains of some major honey yielding plants of the Western Ghats (India). Indian Bee J. 27(1) : 1-28.

Chaubal, P.D. and Kotmire, S.Y. 1980. Floral calendar of bees forage plants of Sagarmal (India). Indian Bee J. 42(3) : 65-68.

Chaudhary, R.K. 1977. Bee forage in Punjab plains (India). Pathankot and adjacent villages. Indian Bee.I. 39(1/4) : 5-20.

Deodikar. G.B. and Thakar, C.V. 1953. A pollen study of major honey yielding plants of Mahabaleshwar hills. Poona village industries committee, $8 \mathrm{pp}$. 
Deodikar, G.B., Thakar, C.V. and Phadke, R.P. 1957. High nectar concentration in floral nectaries of silver oak, Grevillea robusta. Indian Bee J. 19(7/8) : 84-85.

Devadason, A. 1971. Migratory beekeeping in Kerala. Indian Bee J. 33(3/4) : 35-38.

Devadason, A. 1972. Rubber plantation and beekeeping. Indian Bee J. 34(1/2) : 38-39.

Gupta, J.K., Mishra, R.C. and Kumar, J. 1984. Plectranthus as forage for Apis cerana indica F. and Apis mellifera L. Apidologie 15(1) : 75-82.

Gupta, J.K., Kumar,'J. and Mishra, R.C. 1984. Nectar sugar production and honeybee foraging activity in different cultivars of cauliflower, Brassica oleracea var. botrytis. Indian BeeJ. $47: 21-22$.

Gupta, J.K. and Thakur, R.K. 1987. Nectar sugar production and flower visitors of the bramble, Rubus ellipticus Smith (Rosaceae) at Solan, India. Apidologie 18 : 223-30.

Kapil, R.P. and Brar, H.S. 1971. Foraging behaviour of Apis florea Fab. in relation to Brassica campestris var. toria. Proc. 23rd Congr. Apic., Moscow pp. 335-39.

Kohli, N. 1958/59. Bee flora of Northern India. Indian BeeJ. $20: 113-18,132-34,150-51,178-79$, $192-93 ; 21: 7-8,31-32,61-62,83-85,106-07.127-28$.

Krishnaswamy, S.V. 1970. Soapnut trees: a nectar source. Indian Bee J. 32(3/4) : 83.

Mathew, T.J. 1975. The rubber tree as a source of honey in Kerala, India..Glean. Bee cult. 103(6) $: 190$.

Mishra. R.C., Gupta, J.K. and Kumar, J. 1985. Nectar sugar production in different cultivars of peach, Prunus persica L. Indian Bee J. 47 : 37-38.

Mishra, R.C:, Gupta, J.K. and Kumar, J. 1987. Nectar secretion, a mount and type of nectar sugars, insect foraging in Woodfordia floribunda. Apidologie 18(2) : 173-78.

Mishra, R.C. and Sharma, S.K. 1989. Growth regulators effect nectar pollen production and insect foraging in Brassica seed crop. Curr. Sci. 57 : 1297-99.

Nain, M. and Phadke, K.G. 1976. Bee flora and seasonal activity of Apis cerana indica at Pusa (Bihar). Indian Bee J. 38(1/4) : 13-19.

Nair. K. Shakuntala, 1981. Beekeepers of Muzaffarpur (Bihar). Indian Bee J. 43 : 97-100.

Nair, A.G.R., Nagarajan, S. and Subramanian, S.S. 1962. Chemical compositions of pectar in Thumbergia grandiflora. Curr. Sci 33(13): 401.

Nair, P.K.K. and Singh, K.N. 1974. A study of two honey plants, Antigonon leptopus Hook and Moringa pterigosperma Gaertn. Indian J. Hort. 31(4) : 375-79.

Nair, K.S. 1983. Evaluation of importance of litchi as a nectar source. Indian Bee J. 45(4): 108-09.

Narayana, N. 1970. Studies on Indian honeys and bees waxes, Poona, India. CBRI, 1970, 13 pp. MACS, Res. Inst. Poona-4.

Phadke. R.P. 1962. Physico-chemical composition of major unifloral honeys from Mahableshwar (Western Ghats). Indian Bee J. 24(7/9) : 59-65.

Phadke. R.P. 1964. Nectar concentration in Carvia callosa Bremk. Indian Bee J. 26(2) : 22-25.

Phadke, R.P. 1965. Nectar concentration in Thelepaepale ixiocephala Bremk. Indian Bee J. 27(2) : 73-76.

Phadke, R.P., Nair, K.S. and Namdekar, K.U.1970. Studies on Indian honeys. IV. Minor constituents. Indian Bee J. 32(1/2): 28-35.

Rajebhonsale, M.R. and Kapadnis, D.G. 1970. Viscosity of honey under different ambient conditions. Indian Bee J. 32(3/4) : 58-61.

Ramesh, B. 1980. A visit to the cultivated forest area of Peepalpada, U.P. Indian Bee J. 43(3) 86

Rao, G.M. and Lazar, M. 1980. Studies on the behaviour and pollination on onion (Allium cepa L.). Proc. 2nd Int. Conf. Apic Trop. Climates, New Delhi 1980 : 580-89.

Reddi, C..S.. Reddi, E.U.B. and Reddi, N.S. 1980. Floral rewards and honeybee visitation rates in soapnut tree. Proc. 2nd Int. Conf. Apic Trop. Climates, New Delhi 1980:600-02.

Reddy, M.C.M. and Gupta J.K. 1987. Wild cherry, Prunus puddum Roxb., A honey plant. In Social Forestry for Rural Development (ed. P.K. Khosla and R.K. Kohli), I.S.T.S. pp. 207-14.

Saraf, S.K. 1972. Bee flora in Kashmir. Indian Bee J. 34(1/2) : 1-10.

Salyanarayana, I. 1975. Sugar concentration in nectar from Syzygium cumini Skeels. Indian Bee J. $37(1 / 4): 21-24$.

Sharma. P.I. 1958. Sugar concentration of nectar of some Punjab honey plants. Indian Bee J. 20(7) : $81-91$.

Sihag, R.C . and Kapil, R.P. 1983. Foraging strategies of honeybees as determined by quality and quantity of nectar. Proc. Sih Int. Symp. Pollen, Versailles, pp. 51-59. 
Singh, S. 1948. Some important honey plants of the Punjab (India). Rep. Iowa State Apiar. : 34-42. Singh, O.S. and Sharma, V.K. 1972. Nature of sugar secretion in the nectaries of balsam (Impatiens balsamina L). Indian Bee J. 34(1/2) : 32-33.

Singh, G. and Singh G. 1971. Plectranthus rugosus Wall; the major honey plant of Kashmir Valley. Indian Bee J. 33(3/4) : 58-59.

Subramaniam, K. 1979. The role of Forest Department in developing beekeeping in Western Ghat areas of Mạharashtra. Indian Bee J. 41(3/4) : 91 -93.

Wakhle, D.M., Nair, K.S. and Ramesh, B. 1981. Sugar composition in nectars of certain plants. Indian Bee J. 43(1) : 6-8. 


\section{SEASONAL MANAGEMENT}

NECTAR and pollen are not available to bees throughout the year. However, during some parts of the year surplus food is available, minor and subsistence food is available during other periods, whereas bees may face dearth period for certain parts of the year. We also bave different seasons in a year with greatly varying weather conditions and the weather at times may be bard for bees. A beekeeper must handle his bees in such a manner that the colonies are well prepared for the coming honey flow. This has to be done by helping the bees in successfully abridging the dearth period and by reducing the effect of severe weather conditions. Since the honey flow season and weather conditions vary from locality to locality, the management practices cannot be the same everywhere. However, the underlying principles are the same and the beekeeper will have to adjust to their specific conditions. There are hardly any published results on seasonal management in India but the wellestablished practices from the West have been adopted in India with suitable modifications and management suggested and followed during different seasons.

\section{Spring management}

In bills the winters are severe and there is lack of flora, the bees remain confined to their bive for most of the time. The bees have also been facing the problem of maintaining nest temperature. At the onset of spring the colonies emerge in considerably weak condition. It should be the earliest attempt to examine the colonies on a bright, warm and calm day to assess the condition of the colony, working of the queen, amount of brood present, boney and pollen stores and to clean the bottom board debris accumulated during winter. It is a useful management to give a stimulant feeding to colonies when very few spring flowers have blossomed. The stimulant feeding with thin sugar syrup (30 to 40\%) will help the colonies to rear more brood and raise greater foraging force to avail spring and summer flow. This feeding also raises the morale of the bees. It is an established fact that colonies which receive stimulant fe ading produce more honey.

The examination should be done carefully and quickly because robbing is easily induced. All manipulations should be stopped once the robbing becomes apparent and reduce all entrances so that colonies are able to guard against the invasion of robbers. During spring, bee colonies go "all out' to rear brood and invest all resources in increasing their strength. Queen lays more vigorously after winter egg laying rest. More drawn combs are added for expanding brood nest. If the queen is working unsatisfactorily, that is, she is laying sparingly and/or laying drone eggs, efforts must be made to replace the queen at the earliest opportunity. 
It may be pointed out that very weak colonies desert their hives if disturbed unnecessarily and are easily robbed out if they are fed sugar syrup without great care. It is a wise practice to unite them with others and follow the golden rule, "Always help first those colonies that need the least help, leaving the weakest to be helped the last". Colonies which are just below average in strength may be helped by giving them each a frame or two of capped brood from strong colonies. Another good practice is to equalise the strength of the colonies to avoid disparity so that all the colonies require the beekeepers attention at about the same time and respond equally to treatment. During early spring the weather is unsettled and beekeepers are warned against over expanding the brood nest and dividing it into two or more parts by insertion of empty combs or comb foundations because there can be chances of the outlying brood being left unattended by the worker bees. Consequently the neglected brood gets 'chilled' because of treacherous weather that can prevail during early spring. But on the other hand shortage of frames or stores at this time of the year cripples the colony for the whole season and the colony is not fully prepared to avail good honey flow.

Similar management practices in spring are needed under mid-hill and sub-mountainous conditions. But in plains of north India the conditions are different in spring. In most areas extensive Brassica flora is available from October to January. The bees get 3-5 hr for foraging during a day and instead of depletion of strength, there is some build up. Good colonies attain yielding strength and honey extraction is possible in January. The precautions against extension of brood nest, stimulant feeding etc. can be relaxed. Similarly, bees in southern Peninsula of India do not face weather problem. Spring is also a swarming season. Swarm prevention and control measures should be taken.

\section{Honey flow period}

Generally, the swarming season is followed by good honey flow season. Proper management of the bees is essential during these days. It is true that any amount of diligence during the honey flow cannot make amends for the poor management during the preceding months but any oversight during these crucial days is ceratain to effect the year's work of the bees and the beekeeper. To manage the colonies efficiently the beekeeper should have the fullest knowledge of honeyflow trends and the state of the colonies.

The principal function of the beekeeper during honey flow period is to keep the colony morale high. In other words, he should ensure that the honey-gathering instinct is dominant and that the instinct is not checked. Congestion in the hive must be avoided and surplus house bees a re drawn to supers. A colony is particularly liable to have this trouble during honey flow because of rapid nectar income, and the beekeeper should do his best to remain ahead of bees providing space for honey storage. It must be remembered that great deal of space is required for the evaporation of honey than for its final storage. Therefore, drawn combs should be provided liberally. A second super should be added between the first super and the brood chamber and not above the first super. Many times the queen goes to the super chamber and 
lays eggs and honey extraction becomes difficult. At least three weeks before honey extraction a queen excluder should be placed in between brood and super chamber, and queen is confined to brood chamber. The supers can be of full depth or half supers. Handling and various operations are easy with full depth supers because frames can be exchanged between the chambers. But the judgement to use the kind of super depends on the colony strength A. mellifera colonies attain sufficient strength before honeyflow and full depth supers on Langstroth hives are used in India. In case of ISI hives for A. cerana indica, full or half supers are used. In Jammu and Kashmir Langstroth hive is used even for Indian honey bee. In most southern beekeeping areas the Newton hive is still in use, where half super is common. Colony should be examined once a week and frames full of honey should be removed to the sides of the super and such frames can be raised from brood to super chamber. The frames which are three-fourth filled with honey or pollen and one-fourth with sealed brood should also be taken out of brood chamber and in its place empty combs or frames with foundation is added. Bees draw comb foundation better and quickly in brood chamber. The frame with comb foundation should be placed next to the brood nest. Often the beekeeper is short of drawn combs and getting more combs raised would lower honey yield. In such cases, the combs which are completely sealed or two-thirds capped may be taken out for honey extraction and returned to the supers after honey extraction. Such extraction, apparently gives an incentive to the colonies and helps to activate the bees to store more honey. Two or three such extractions are usually possible during a surplus flow. The extraction of uncapped honey should be avoided because this unripe honey has higher moisture percentage and is liable to ferment. Honey extraction, after the flow is over, can induce severe robbing not within the species but also between the species too. It is a common experience that $A$. dorsata robbing domesticated hive bees become beyond control and loss of colonies is the result.

On warm days, bees are noticed to gather in clusters at the entrance. This is a sign of congestion and poor ventilation. This affects the honey gathering instinct. The situation should be remedied promptly by improving ventilation by removing the entrance rod or shoving the supers backward.

\section{Honey extraction}

When the honeyflow begins to slow down, the frames containing honey should be removed for extraction. As discussed earlier honey can also be extracted during the flow if super frames are ready. The honey should finally be extracted when bees a re still bringing the nectar. To remove honey combs, a colony is smoked, the desired combs taken out and bees brushed off with a soft brush or a bunch of green grass. These combs are placed in bee tight hive bodies, removed to the extraction room and stocked one above the other. A real beekeeper would never rob the colony of its honey stock but takes away the surplus only. Depending upon the strength, $5-15 \mathrm{~kg}$ of honey should be left with the colony of $A$. mellifera for summer and monsoon dearth 
periods. Apis cerana indica is a frugal species and colony strength is also less and 5-7 $\mathrm{kg}$ of honey stores may suffice for dearth period.

For extraction of honey a room with wire-gauged bee-tight doors is necessary. It is better if it has double doors. In case extraction room is not available then honey can be extracted in the open during night. To uncap the frames either a steam heated double walled uncapping knife or plain uncapping knives with provision for heating them in boiling water should be arranged. Electrically heated uncapping knives with a thermostat are used in big apiaries. A tray with expanded metal screen is also required. If too hot knives a re used lot of wax from the cells would melt into the honey and solidify after sometime into an undesirable layer over it. The uncapped frames should be placed in hive bodies with drip trays underneath them to await their transfer to the extractor. Beginning slowly the extractor should be worked at about $150 \mathrm{rev} / \mathrm{min}$ for about $1 \frac{1}{1} / 2-2 \mathrm{~min}$. Then the sides of the frames are reversed and the extractor is again worked. Empty frames are stocked in hive bodies till they are returned to supers in the bee colonies. It is advisable to make arrangements for straining and packing honey in tins promptly to obviate a need for its subsequent heating. Freshly extracted honey is warm and hence easy to strain. Wax cappings are handled for wax extraction.

After the job has been done, the place should be swabbed with water and the appliances cleaned. Hive bodies are washed to remove honey drops. The empty wet combs should be returned to the bees for cleaning and the hive entrances be reduced to avoid robbing.

\section{Summer routine}

In most localities the honeyflow is followed by a summer dearth period. With the ceasing of honey flow season they develop a strong tendency to protect their stores and become nervous and excited. Bees start throwing out drones and are not allowed to return because they are now useless in the colony. Unmanaged colonies stop brood rearing in order not to starve in future. There is sudden decline in colony strength due to the death of old and decrepit bees who have put in strenuous work in gathering honey. Bees, especially $A$. cerana indica gnaw old and empty combs. Besides protecting their hives against the enemies and robber bees, the bees have to keep their hive cool and properly ventilated (Fig.61). Summer is rather a testing period for the colony and well compared to the difficult winter season in the west.

In a 'left alone' colony, the bees mostly stay indoors, do little work, remain listless and wait for the developing brood to emerage. The queen stops egg laying and if she persists in depositing eggs, they are neglected by the bees and allowed to shrivel. When almost all the brood has emerged and not enough is left, the colony absconds. Only empty combs and sometimes infested with wax moth are left. The deserting bees behave almost in a similar fashion as swarming bees except that these bees rise very high and it is rather difficult to make them settle down. Desertion or absconding is little known in Apis mellifera but the tendency is very strong in Indian 


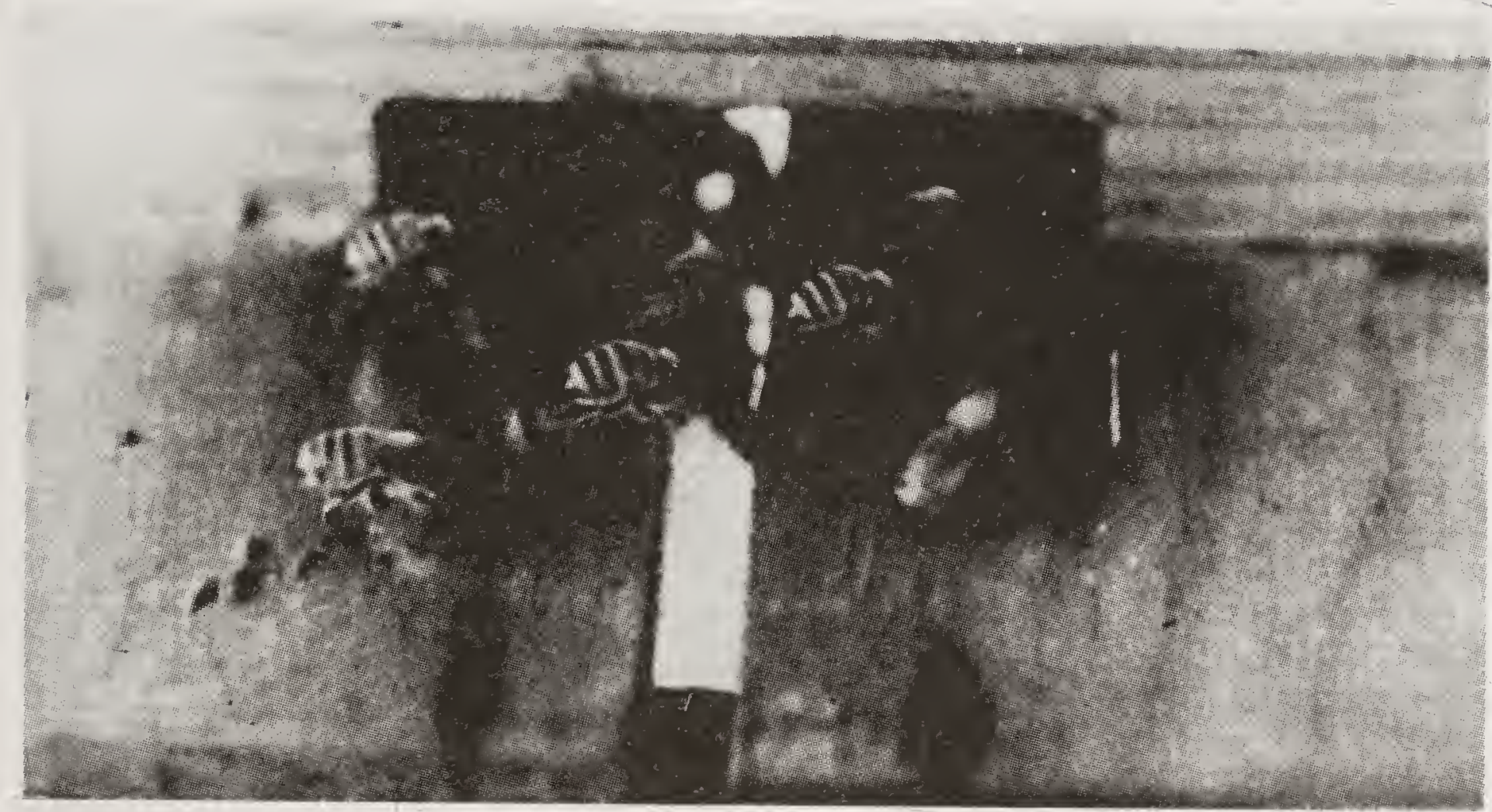

Fig. 61. Fanning bees in the attempt to lower down hive temperature in summer.

honeybee. Apis mellifera colony would rather die because of starvation or due to the attack of enemies but show little tendency to abscond.

The best thing to do during this period is to avoid broodlessness in colonies and stimulate them to rear brood. The strong colonies with sufficient store would continue to rear some brood during summer. Colonies headed by young prolific queens will continue to lay eggs. Strong colonies are less troubled by enemies and are able to take advantage of subsistence floral sources. The colonies cannot be kept in the open in the sun. These should always be shifted to a place with thick shade. Beekeeper can further help bee colonies by placing them under open straw huts. The hut is of ' $L$ ' shape from east to west and west to south. At some places the temperature rises as high as $45^{\circ}-47^{\circ} \mathrm{C}$ and gunny bags, moistened twice at noon and in the afternoon, can be spread over top covers (Fig.62). Ventilation of hive is to be ensured but holes, cracks and crevices also allow easy passage for enemies. The brood and super chamber can be raised slightly by putting shavings or splinters of wood in between. The space so made should not allow the bees to pass through to avoid robbing. Sufficient honey stores are must in a colony. Beekeepers should have complete information of subsistence flora that would be available to the bees and make his judgement about the stores to be allowed at the time of last honey extraction. The brood rearing in summer can also be boosted by feeding pollen substitute or pollen supplement, a continuous supply of which is required during dearth period since these are not stored in cells. Frequent examination of colonies should be avoided. The above management practices during summer would check absconding of colonies. The principle is: "All efforts should be made to add to the comforts of bees."

\section{Monsoon problems}

Monsoon season follows hot summer months in India. In some a reas bees are confined to hives for long intervals because of continuous rains. Large 


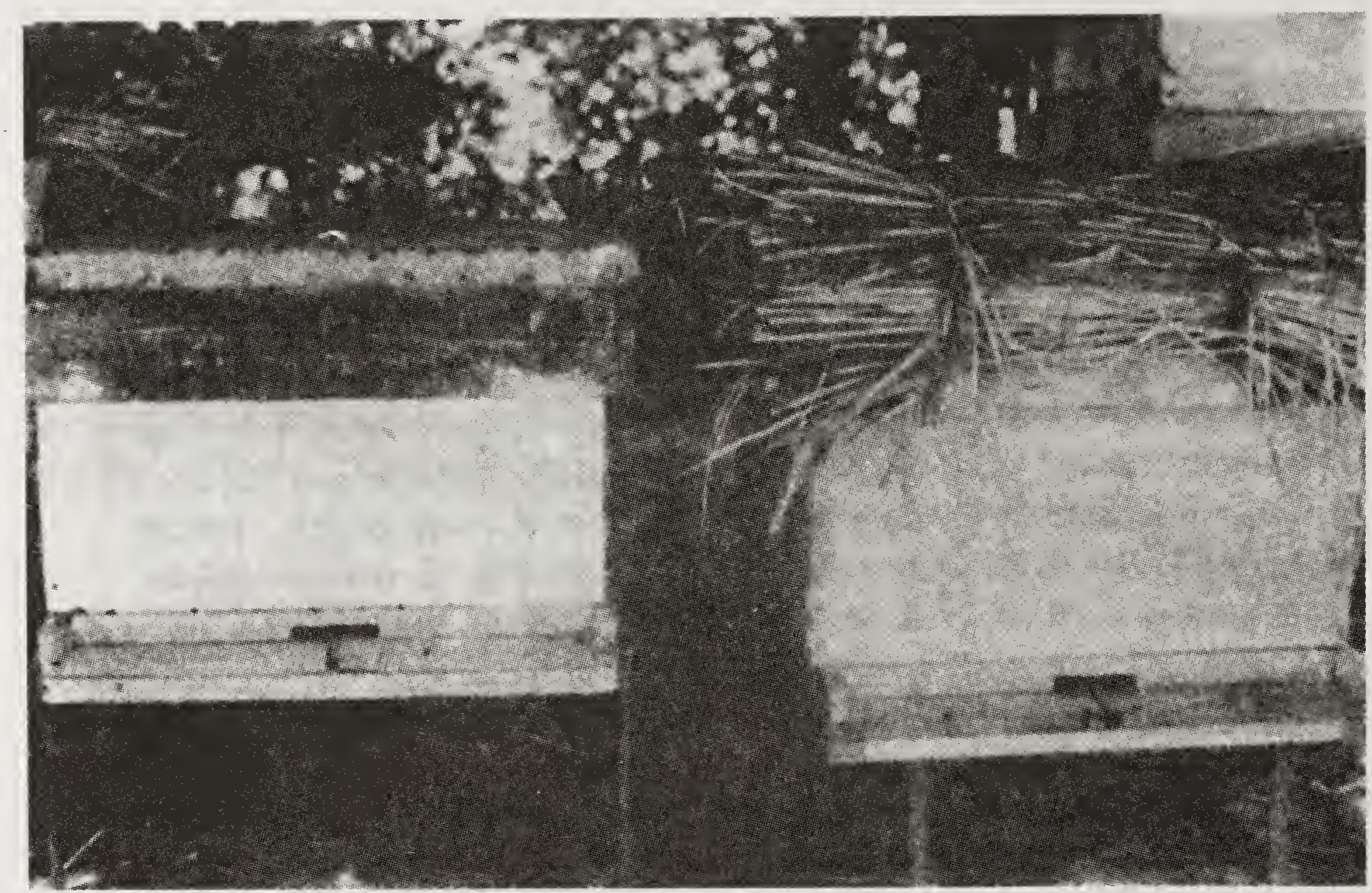

Fig. 62. Rice straw matting drenched with water helps bees in lowering hive temperature in summer.

number of forager bees are lost in sudden storms or downpours reducing the strength of the colonies. High humidity in the hive, coupled with high temperature, creates an unfavourable environment for bees. They become lethargic and listless, and often suffer from dysentery. Pollen in comb cells becomes mouldy and unripe honey may ferment. Bee enemies, on the other hand grow in number and further weaken the colonies. The tendency to rob is accentuated.

Good management requires the intensification of the measures usually employed in summer. Locating the apiary in the thick groove of trees where air stagnates and it is often hot and close, should be avoided. During rains, candy or dry sugar should be given to the bees if artificial feeding becomes necessary. The feeding of pollen supplements and substitutes is useful.

It is often noticed during the monsoon that a few weak colonies become queenless and laying workers appear. In most cases it is difficult to make such colonies accept new queens. Moreover, there are no drones and new queens cannot be mated. It is advisable to unite them with others. Regular examination and constant vigilance to check robbing is important because severe robbing often leads to queen mortality.

\section{Autumn management}

Appropriate management of colonies in autumn is the key to successful wintering and obtaining high honey harvest in future season. Colonies should raise many bees which would go for overwintering. The queens of preceding spring period build up or of those raised before honeyflow season continue to lay eggs for longer duration in areas with severe winter conditions. But queens of previous year slow down and lay only few eggs in autumn. 
Therefore, age of the queen makes a difference in colony strength that overwinter. It is a useful practice to unite the weaker colonies and not to allow unreliable colonies to enter winter.

In hilly areas bees avail rich autumn flow in September-October. The colonies should be handled as is done during a boneyflow season. During this period the colonies may prepare both for swarming and supersedure but the number of queen cells raised are fewer and the queens of the season are poorer as compared to those raised during spring or early summer. Careful beekeeper will not extract all honey but leaves enough stores for overwintering. In certain a reas bees may not have flora to accumulate sufficient honey stores in autumn. Such colonies have to be fed with sugar syrup if the area has no winter flora or where winters are severe, Sugar syrup in higher concentrations $(60-70 \%)$ is always given in large doses. Under plains conditions Brassica species start flowering from the manth of October and unirrigated early Brassica species may present food to bees even during September. The Brassica flow continues till the beginning of February. Though the working hours in winter are reduced to 3-5, they collect enough stores and there is no need of ensuring large stores for overwintering. But even under these conditions, the bee colonies must rear large brood in autumn to avail winter sources.

Queen stops egg laying in autumn if there are less or no honey and pollen stores, and this is done to avoid starving in future. Such queens are difficult to induce egg laying even by artificial feeding because even in winter free zones in sub-tropical India, the bees respond to seasonal variations and the bee activity fades away as it happens in areas where they prepare for wintering. Therefore, honey and pollen stores should always be ensured during autumn to keep the queen and the colony active. Such colonies are also to explore and avail every subsistence source. Good beekeeper would always attempt to locate his apiary close to the sources of autumn honey flow.

In lower hills and sub-mountainous regions as well as in plains, the autumn is more or less a dearth period. If the summer is long followed by monsoon then broodlessness persists and absconding may be explicit which is more prominent in A. cerana indica but is little known in $A$. mellifera.

\section{Winter management}

Honeybees live in a thermal environment of their own and maintain colony nest temperature between $32^{\circ}$ and $35^{\circ} \mathrm{C}$. The bees form a cluster when the atmospheric temperature drops below $10^{\circ} \mathrm{C}$. This, roughly spherical cluster becomes tighter as the temperature drops further down. The cluster is composed of inner and outer shell, the latter serves as insulation and prevents the heat loss. Bees change their places between the inner and the outer shells. Bees raise the temperature by muscular movements and is possible by the consumption of honey. In very cold winter, the bees go out on short flights to defecate. They can retain the faeces in rectum for long period when weather does not allow even short flights. Strong colonies overwinter well because larger number of bees can produce heat and retain it. 
Bee colonies can be helped to overwinter by saving their energy in raising nest temperature. Wooden hives do give protection to bees against the vagaries of weather. But care is needed to further protect colonies from frosty winds and high humidity. All cracks, crevices and holes other than entrance should be plugged. The direction of hives should never be facing to north to avoid winds entering into the hives. The colonies find it difficult to regulate the nest temperature when relative humidity is high, that is, about $70-75 \%$. The colony should not be located in damp places and under thick grooves of vegetation. Periodic inspection to verify the food stores is essential in winter.

Insulation of hives belps to reduce consumption of honey and saves energy of bees. Insulation is desirable in localities which have long spells of cold or where there is wide range between day and night temperatures. For purpose of insulation the climatic zones in different beekeeping tracts in the country can be grouped in 4 categories; viz, (a) equitable temperature throughout the year and the minimum temperature not falling below $10^{\circ} \mathrm{C}$ at any time of the year, (b) three cold months namely, December, January and February with the days generally bright and warm and the nights cold with frosty mornings as in north Indian plains. The fluctuations between the maximum and the minimum temperatures during $24 \mathrm{hr}$ may be $5^{\circ}-21^{\circ} \mathrm{C}$ in the open and honeyflow from Brassica spp. is available, (c) four cold months from November to February with cold being more intense and a large number of frosty days (lower hilly tracts). Minor honey flow froin some Brassica, Prunus and Litsea may occur, (d) five cold months from November to March with severe cold snowfalls and cold wind (higher hilly tracts). No floral sources are available during the period.

Because of differences in winter weather, different management practices are needed in different regions. Whereas no insulation will be necessary in region (a), light insulation will be required in region (b). In this second region, bee colonies start expanding towards the second half of winter, therefore light insulation should be so provided that examination and providing extra space should be easy. Strong colonies with bees on 8-10 frames actually need no insulation and can winter well. In this region good colonies yield surplus boney from Brassica in January or early February. In region (c) the thickness of insulation should be increased, and in region (d) it should be $7-10 \mathrm{~cm}$ on all sides of the hive. This winter packing is given at the end of autumn and after the colonies have been properly prepared for winter season. Only strong colonies with number of young bees and enough honey and pollen reserves should be overwintered. Weak colonies will not be able to pull through the winter and should be united with others.

\section{Winter hive packing}

Finely chopped dry grass, wood shavings, saw dust, dry leaves, chopped rice straw or wheat straw are the bandy packing materials (Fig. 63), though thermocol and woollen rugs can also be used. In regions (b) and (c) packing can be given in the brood chamber, if the colony is weak, by packing the space beyond dummy board. The packing material is also packed between 


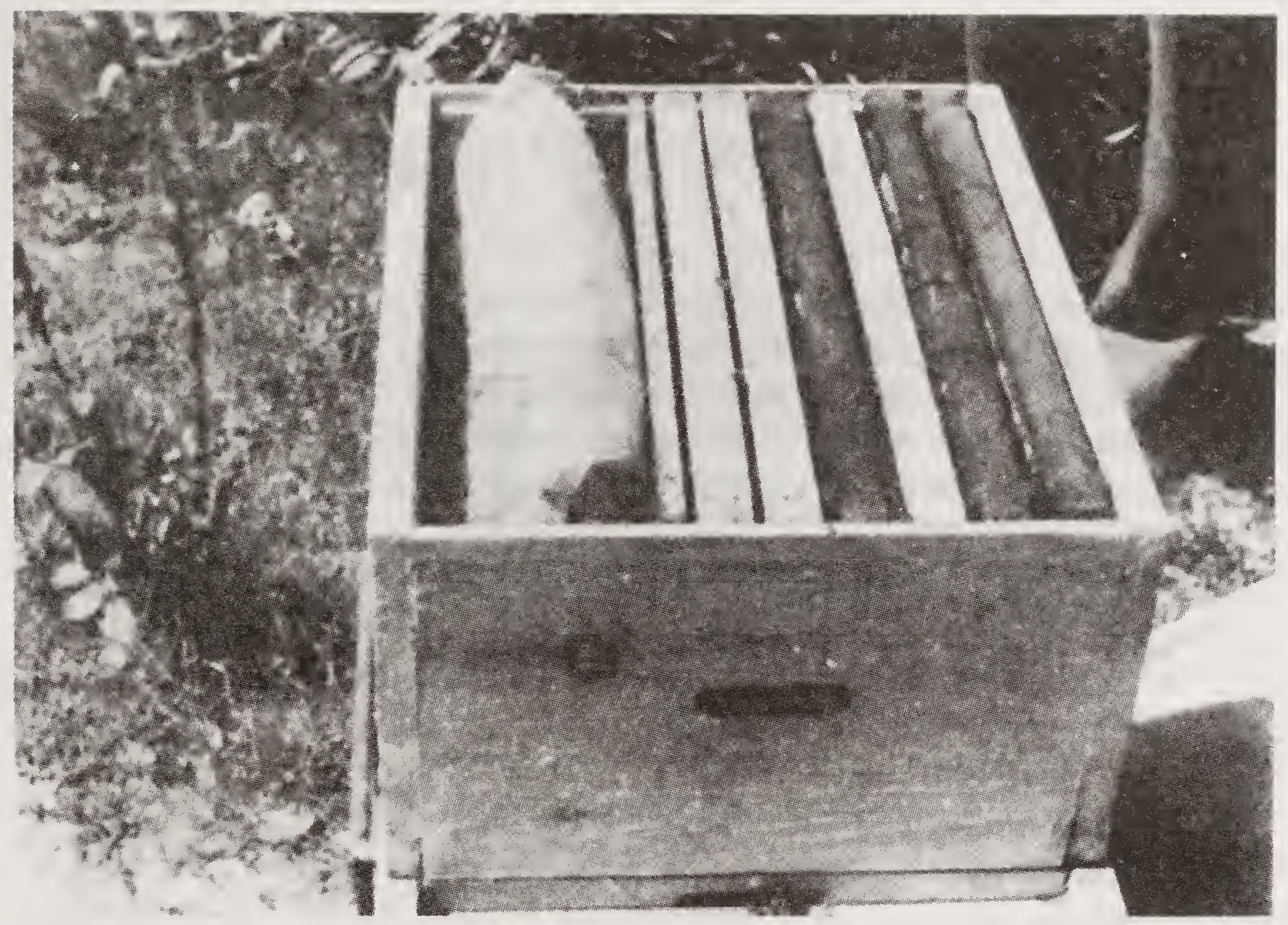

Fig. 63. Packing hive with rice straw in polythene bags: insulation.

the inner and top cover. In case of the region (d) thick packing 'may be needed on all sides of the hive. The packing material is kept in place with strings or water proof tar paper wrapped over the packing material. Care should be taken that packing material should not be moist since the moisture makes them poor insulators. If the hives are located in a protected place, the packing material can be kept in position around the hive with old pieces of gunny bags. 


\section{DISEASES OF BEES AND THEIR ENEMIES}

THERE has been a revolution in the methods of beekeeping for efficient management of bee colonies. Prevention and control of diseases and enemies has been an essential aspect of management. Honeybees are affected by large number of viral, bacterial and protozoan organisms, ecto- and endo-parasitic mites, insects and non-insect enemies. The extent of losses varies from death of some brood or adults to complete annihilation of colonies. Colonies may survive the infection or infestation but any extent of severity leads to loss in honey yields. Diagnosis of maladies has been possible by refined methods with the help of sophisticated equipments. But essentially the need is to detect the infection at the initial stages because it is easy to treat the colonies at that stage.

Bee diseases are spread from one colony to another or from one apiary to a nother mainly by robber bees, swarms or migration of colonies. Because of these quarantine measures within the country or between the countries which have geographical contiguity are not feasible. Restrictions on the movement of bees between the countries which are separated by barriers seems useful and practicable.

Spread of disceases is also frequent by manipulative operations in the apiary. Beekeeper may be required to transfer honey and pollen combs from one colony to another. Similarly weaker colonies may need to be strengthened by transferring brood frames or combs with adult beeș. Even uniting of colonies has to be resorted to in certain circumstances. Providing water in a container in apiary is a nother hazardous practice. All these manipulations lead to spread of diseases and parasites from affected to healthy colonies. Disease spread is even possible through hands, hive tools, etc. while examining the colonies. Therefore, beekeeping requires not only the knowledge of basic principles of colony management but beekeeper should be well fa miliar with the nature of bee diseases. Early diagnosis of disease infection and prompt application of control measures is very important.

Many diseases which affect honeybees in other countries are not yet serious in India but there are isolated reports of their incidence except for some viral diseases: Any known diseases in the West can be expected to appear in epidemic form in India too and, therefore, very brief account of all the diseases and enemies is given here.

\section{VIRAL DISEASES}

Many viral diseases of honeybees are known but the extent and severity of different viruses vary. The bee viruses appear to be species specific. Three viruses, viz. Apis irridescent virus, Thai sac brood virus and Kashmir bee 
virus, have been reported from India. Out of these three, the first two have been devastating Apis cerana indica in some parts of the country.

\section{Thai sac brood virus}

This viral disease was first detected in India in Apis cerana indica in Meghalaya in 1978 (Kshirsagar et al., 1982). The causative virus multiplies in adults which transmit the virus to larvae. Trophallaxis, swarms and drifting are believed to be the reasons of spread of the disease. Exchange of brood combs in between the colonies is the reason of spread within the apiary. Sac brood disease which is closely related virus disease in many other countries, is not considered serious but Thai sac brood took up to $95 \%$ toll of Indian honeybee colonies during early eighties in northern India. The disease occurred with similar severity in south India during 1991-92.

Symptoms. (i) Brood die in prepupal but in unsealed stage. (ii) Dead larvae straighten out and lie on their backs, with tip of the head capsule turned upwards. (iii) Dead prepupae turn into sac like structure. (iv) Affected larvae are yellow or greyish, later darkening to blackish; the change in colour first starts from mouth-parts and head. (v) Dead larvae and prepupae dry up in brood cells forming loose scales.

No definite preventive or remedial measures against the disease are available, but keeping the colonies strong, avoiding exchange of hive parts and restricted movement of bees are suggested. Natural selection of tolerant colonies is expected and in endemic areas the surviving colonies can be multiplied with screening for disease tolerance in each generation.

\section{Apis iridescent virus}

This viral disease was reported from north-western states of India in seventies. The virus is specific to $A$. cerana indica and even in mixed apiaries the disease does not appear in $A$. mellifera. It forms crystals in tissues where the virus multiplies. The crystals appear bright blue-violet or green when observed under miscroscope with incident light. This is also revealed even with hand lens, or in sunlight with the naked eye. The virus multiplies in the fat bodies and other tissues of adult bees.

Symptoms. (i) Infected bees form clusters on the inside and later on the outside walls of the hive, hence it is also called as 'clustering disease'. (ii) Many crawling bees a re found on the ground. (iii) Worker bees stop foráging, sit listlessly and even brood rearing is stopped. (iv) Queen stops egg laying and the eggs laid are not attended by nurse bees. (v) Death of the entire colony follows.

\section{Kashmir bee virus}

The virus was first isolated from diseased samples of $A$. cerana indica from Kashmir. Strains of Kashmir bee virus bave also been found in Apis mellifera in Australia. All stages of development die in the affected colony. The virus is transmitted by injection or even by contact of body surface and death is fast. 


\section{Bee viruses not found in India}

There are several viruses found infecting Apis mellifera in other countries but not yet reported from India. Now $A$. mellifera is established in India and is fast spreading, therefore, any of the diseases known in the West can appear in India too in future.

Sac brood virus. Infected larvae fail to pupate and lie stretched on their back with head turned upwards. The larva becomes sac-like because fluid is filled in between the new integument and the unshed skin. Colour of the larva turns pale-yellow and finally becomes dark brown; the darkening starts from the head region. The virus multiplies in hypopharyngeal glands of adult bees.

Paralysis virus. The infected bees have trembling motion of wings and bodies. They are unable to fly, crawl on the ground and bees become dysentric. There is no particular season of the year for viral infection but overcrowding is suggested to enhance infestation.

Black queen cell virus. Infected queen larvae turn yellow and resemble sacbrood infected larvae. The queen cell tips become black.

Bee Virus $X$ and $Y$. Cloudy wing particle and Acute Bee Paralysis are other viral diseases of $A$. mellifera.

\section{BACTERIAL DISEASES}

\section{American foul brood}

Bacillus larvae is the causative bacterium of the disease. The disease occurs in temperate and sub-tropical regions of the world. There is solitary report of the disease incidence in India on Apis cerana indica (Singh, 1961) but no incidence has been observed on Apis mellifera since its establishment in the country.

Infected brood is invariably found dead after spinning of the cocoon in the sealed cell (Fig.64). The dead prepupae lie straight with head towards the opening of the cell. Cell capping of infected brood becomes darker in colour, sunken and perforated. A tooth pick inserted into the body of prepupa and drawn out shows ropiness. The putrefying brood turns brown and has fish glue odour. Dead broods dry up into scales which adhere to the cell bottom. Large number of spores are formed and are present in the scale. Hive bees pick-up the spores while cleaning the cells and spread the disease. The spores germinate in the gut of the larvae, the rods penetrate the gut wall and multiplication takes place in the body cavity. The spores are very resistant and they remain infective even under desiccation for 35 years. The disease may subside during some parts of the year and reappear later. There is no seasonal cycle and outbreak appears when the brood is present.

Destruction of affected colonies and the equipment, though suggested, is a costly and cumbersome measure. Fumigation can be resorted for sterilizing the equipment. Formaline@6 ml per litre volume space sterilizes the equipment in a fortnight. Ethylene oxide, $1 \mathrm{~g} /$ litre space at $43^{\circ} \mathrm{C}$ for $48 \mathrm{hr}$ 


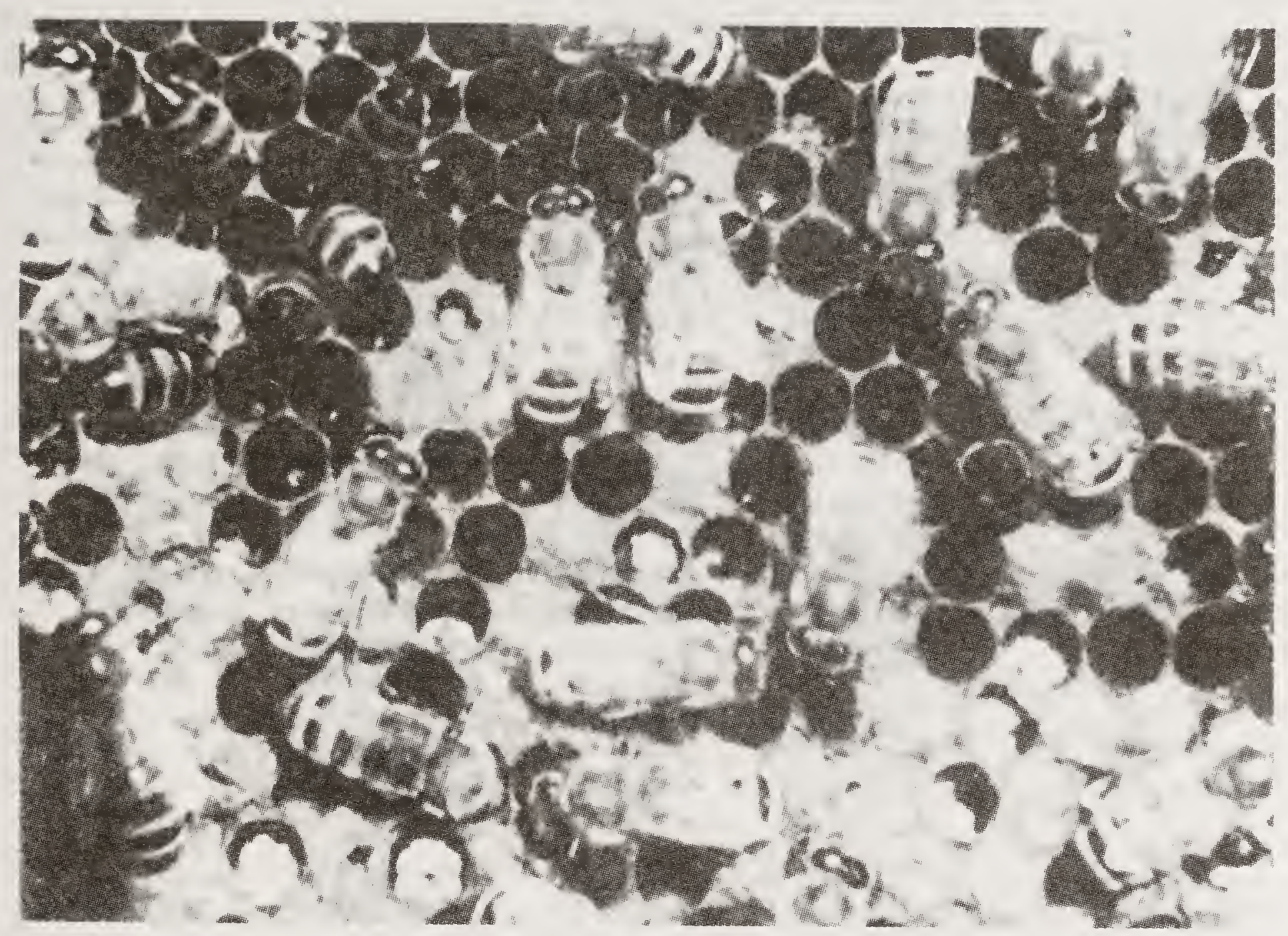

Fig. 64. Severe infection of bacterial brood disease; dead pupae and prepupae, uncapped and punctured sealed cells are visible.

is effective for sterilization but forms explosive mixture with air. Many antibiotics have been tested with variable efficacy. Terramycin 250 $400 \mathrm{mg}$ in 5 litres of sugar syrup fed to the diseased colony twice at weekly intervals is effective. Antibiotic treatment can be made as a routine prophylactic measure in case the disease appears in the country. Resistant bees. have been selected in the USA on the basis of presence of genes responsible for the expression of bee behaviour in uncapping the cells of dead brood and removing the same. The resistant stocks are available in country like USA.

\section{European foul brood}

The causal bacterium was earlier placed in the genus Streptococcus but in 1981 Bailey and Collins showed that the bacterium have nucleic acid composition which qualifies to place it under different genus and it was named as Melissococcus pluton. Diseased larvae are killed usually when 4-5 days old. Diseased larvae become flaccid, turn brown and give foul-sour smell. European foul broôd disease is present in most countries. Infection was once observed in Maharashtra in 1971 on A. cerana indica by Diwan and co-workers. Bacteria, on swallowing with food, multiplies in mid gut and are discharged with faeces. Older larvae are less susceptible to infection. The extent of disease is higher in spring and there is recovery during honey flow. Control of the disease is achieved by sterlizing the equipment with ethylene oxide and Terramycin feeding as explained under American foul brood. 
Diagnosis, cause and spread of brood diseases

\begin{tabular}{|c|c|c|c|c|}
\hline Character & $\begin{array}{l}\text { American } \\
\text { foul brood }\end{array}$ & $\begin{array}{l}\text { European } \\
\text { foul brood }\end{array}$ & $\begin{array}{l}\text { Para } \\
\text { foul brood }\end{array}$ & Sac brood \\
\hline $\begin{array}{l}\text { General appearance } \\
\text { of brood combs }\end{array}$ & $\begin{array}{l}\text { Brood irregular; } \\
\text { inter-mingling } \\
\text { of capped, open } \\
\text { and punctured } \\
\text { cells; much dead } \\
\text { brood in capped } \\
\text { cells; cells with } \\
\text { punctured cappings } \\
\text { and cells un- } \\
\text { capped by bees }\end{array}$ & $\begin{array}{l}\text { Brood irregular } \\
\text { dead brood } \\
\text { mostly in } \\
\text { open cells }\end{array}$ & $\begin{array}{l}\text { Brood iregular; } \\
\text { most dead } \\
\text { larvae in } \\
\text { open cells; } \\
\text { varying amount } \\
\text { of dead brood } \\
\text { in sealed } \\
\text { cells }\end{array}$ & $\begin{array}{l}\text { Brood slightly } \\
\text { irregular; dead } \\
\text { brood mostly } \\
\text { in cells with } \\
\text { punctured } \\
\text { cappings or } \\
\text { in uncapped } \\
\text { cells. }\end{array}$ \\
\hline $\begin{array}{l}\text { Cappings over } \\
\text { dead brood }\end{array}$ & $\begin{array}{l}\text { Many punctu- } \\
\text { red, sunken and } \\
\text { discoloured }\end{array}$ & $\begin{array}{l}\text { Few cappings } \\
\text { sunken, pun- } \\
\text { ctured or dis- } \\
\text { coloured }\end{array}$ & $\begin{array}{l}\text { Cappings over } \\
\text { dead brood } \\
\text { punctured, dis- } \\
\text { coloured, } \\
\text { sunken or thi- } \\
\text { ckened and } \\
\text { sharply dep- } \\
\text { ressed in } \\
\text { the centre }\end{array}$ & $\begin{array}{l}\text { Usually } \\
\text { punctured }\end{array}$ \\
\hline $\begin{array}{l}\text { Proportion } \\
\text { of dead } \\
\text { brood }\end{array}$ & $\begin{array}{l}\text { Varying from } \\
1 \text { to } 75 \%\end{array}$ & $\begin{array}{l}\text { A few coiled } \\
\text { larvae to most } \\
\text { of the larvae } \\
\text { in open cells } \\
\text { and a few in } \\
\text { capped cells }\end{array}$ & $\begin{array}{l}\text { A few larvae } \\
\text { to practi- } \\
\text { cally all } \\
\text { the brood }\end{array}$ & $\begin{array}{l}\text { Small amount } \\
\text { of brood } \\
\text { dead }\end{array}$ \\
\hline $\begin{array}{l}\text { Age at the } \\
\text { time of } \\
\text { death }\end{array}$ & $\begin{array}{l}\text { Late larval and } \\
\text { early pupal } \\
\text { stages, rarely } \\
\text { coiled stage }\end{array}$ & $\begin{array}{l}\text { Coiled stage, } \\
\text { occasionally } \\
\text { late larval } \\
\text { stage }\end{array}$ & $\begin{array}{l}\text { Coiled stage, } \\
\text { occasionally } \\
\text { late larval } \\
\text { and early } \\
\text { pupal stages }\end{array}$ & $\begin{array}{l}\text { Late larval } \\
\text { stage; occasion- } \\
\text { ally coiled lar- } \\
\text { val and pupal } \\
\text { stages }\end{array}$ \\
\hline $\begin{array}{l}\text { Position of } \\
\text { dead brood }\end{array}$ & $\begin{array}{l}\text { Fully extended } \\
\text { on floor of cell, } \\
\text { tail turned up } \\
\text { on bottom, head } \\
\text { lying flat, great } \\
\text { regularity }\end{array}$ & $\begin{array}{l}\text { Coiled on bo- } \\
\text { tlom or twi- } \\
\text { sted on side } \\
\text { walls, few } \\
\text { larvae fully } \\
\text { extended on } \\
\text { floor of cell; } \\
\text { very irregu- } \\
\text { lar }\end{array}$ & $\begin{array}{l}\text { Coiled on bo- } \\
\text { ttom, twisted } \\
\text { on side walls } \\
\text { or fully ex- } \\
\text { tended on } \\
\text { the floor of } \\
\text { the cell; } \\
\text { great irregu- } \\
\text { larity }\end{array}$ & $\begin{array}{l}\text { Fully ex- } \\
\text { tended :on } \\
\text { floor; } \\
\text { heads pro- } \\
\text { minently } \\
\text { raised, } \\
\text { great irre- } \\
\text { gularity }\end{array}$ \\
\hline $\begin{array}{l}\text { Colour of } \\
\text { dead brood }\end{array}$ & $\begin{array}{l}\text { From dull-whi- } \\
\text { te to dark-bro- } \\
\text { wn or almost } \\
\text { black }\end{array}$ & $\begin{array}{l}\text { From dull white } \\
\text { to yellowish- } \\
\text { white; often } \\
\text { dark-brown }\end{array}$ & $\begin{array}{l}\text { From dull- } \\
\text { white to re- } \\
\text { ddish-brown }\end{array}$ & $\begin{array}{l}\text { Greyish to } \\
\text { straw-colo. } \\
\text { ured to } \\
\text { black; head } \\
\text { end usually } \\
\text { darker }\end{array}$ \\
\hline $\begin{array}{l}\text { Kind of brood } \\
\text { affected }\end{array}$ & $\begin{array}{l}\text { Mostly worker, } \\
\text { occasionally } \\
\text { drone, rarely } \\
\text { queen }\end{array}$ & $\begin{array}{l}\text { Worker, drone } \\
\text { and queen }\end{array}$ & $\begin{array}{l}\text { Worker, } \\
\text { drone and } \\
\text { queen }\end{array}$ & $\begin{array}{l}\text { Usually } \\
\text { worker but } \\
\text { sometimes } \\
\text { drone }\end{array}$ \\
\hline $\begin{array}{l}\text { Consistency of } \\
\text { dead brood }\end{array}$ & $\begin{array}{l}\text { At first watery } \\
\text { or slightly vi- } \\
\text { scid, becoming }\end{array}$ & $\begin{array}{l}\text { At first soft } \\
\text { and watery } \\
\text { afterwards }\end{array}$ & $\begin{array}{l}\text { At first soft } \\
\text { and watery, in } \\
\text { open cells be- }\end{array}$ & $\begin{array}{l}\text { Skin fairly } \\
\text { tough, con- } \\
\text { tents wa - }\end{array}$ \\
\hline
\end{tabular}




\begin{tabular}{|c|c|c|c|c|}
\hline Character & $\begin{array}{l}\text { American } \\
\text { foul brood }\end{array}$ & $\begin{array}{l}\text { European } \\
\text { foul brood }\end{array}$ & $\begin{array}{l}\text { Para } \\
\text { foul brood }\end{array}$ & Sac brood \\
\hline & $\begin{array}{l}\text { ropy; finally } \\
\text { brittle }\end{array}$ & $\begin{array}{l}\text { pasty, rarely } \\
\text { viscid and } \\
\text { ropy; scales } \\
\text { tough, rubbery } \\
\text { or brittle }\end{array}$ & $\begin{array}{l}\text { coming pasty } \\
\text { and brittle in } \\
\text { capped cells } \\
\text { frequently be- } \\
\text { coming ropy fi- } \\
\text { nally tough and } \\
\text { leathery }\end{array}$ & $\begin{array}{l}\text { tery and } \\
\text { granular, } \\
\text { scales tough } \\
\text { brittle } \\
\text { when comp- } \\
\text { letely dry. }\end{array}$ \\
\hline Scales & $\begin{array}{l}\text { Uniformly ex- } \\
\text { tended on lower } \\
\text { side wall, tail } \\
\text { curved up, dead } \\
\text { pupae with ton- } \\
\text { gue extended } \\
\text { upwards, often } \\
\text { attached to } \\
\text { upper cell wall; } \\
\text { difficult to re- } \\
\text { move from cell }\end{array}$ & $\begin{array}{l}\text { Usually coiled } \\
\text { on bottom of } \\
\text { cells; often } \\
\text { Irregularly } \\
\text { Ewisted; some- } \\
\text { times fully } \\
\text { extended; tra- } \\
\text { cheae often } \\
\text { clearly visi- } \\
\text { ble, tough } \\
\text { and rubbery; } \\
\text { easy to remove } \\
\text { from cells }\end{array}$ & $\begin{array}{l}\text { Coiled on bo- } \\
\text { ttom; irre- } \\
\text { gularly twis- } \\
\text { ted; on side } \\
\text { walls or fully } \\
\text { extended in } \\
\text { the cell; tra- } \\
\text { cheae some- } \\
\text { times visible; } \\
\text { easily removed } \\
\text { from the cell }\end{array}$ & $\begin{array}{l}\text { Uniformly } \\
\text { extended } \\
\text { from lower } \\
\text { side of } \\
\text { wall; head } \\
\text { prominently } \\
\text { raised; out- } \\
\text { line wavy; } \\
\text { greyish- } \\
\text { brown to } \\
\text { nearly } \\
\text { black; head } \\
\text { darker; } \\
\text { easily removed } \\
\text { from cell. }\end{array}$ \\
\hline Odour & $\begin{array}{l}\text { Distinct odour } \\
\text { in early stages; } \\
\text { gluepot odour } \\
\text { in brown ropy } \\
\text { remains and } \\
\text { scales }\end{array}$ & $\begin{array}{l}\text { No specific } \\
\text { odour, sour } \\
\text { odour in } \\
\text { partly decayed } \\
\text { remains; odours } \\
\text { variable }\end{array}$ & $\begin{array}{l}\text { Resembles } \\
\text { E.F.B. but } \\
\text { more in- } \\
\text { tense }\end{array}$ & $\begin{array}{l}\text { Absent or } \\
\text { slightly } \\
\text { sour }\end{array}$ \\
\hline $\begin{array}{l}\text { Causative } \\
\text { organism }\end{array}$ & $\begin{array}{l}\text { Bacillus lar- } \\
\text { vae White }\end{array}$ & $\begin{array}{l}\text { Melissococcus } \\
\text { pluton White }\end{array}$ & $\begin{array}{l}\text { Bacillus para- } \\
\text { alvei Burn- } \\
\text { side }\end{array}$ & $\begin{array}{l}\text { A filtera- } \\
\text { ble virus } \\
\end{array}$ \\
\hline $\begin{array}{l}\text { Spread of } \\
\text { disease }\end{array}$ & $\begin{array}{l}\text { Through hive } \\
\text { parts, combs, } \\
\text { honey }\end{array}$ & $\begin{array}{l}\text { Drifting, nulse } \\
\text { bees }\end{array}$ & $\begin{array}{l}\text { Drifting, } \\
\text { nurse bces }\end{array}$ & $\begin{array}{l}\text { Drifting, } \\
\text { nursc bees }\end{array}$ \\
\hline
\end{tabular}

\section{PROTOZOAN DISEASE}

\section{Nosema apis}

This is a spore forming protozoan infecting adult bees. Bees become dysentric with distended and swollen abdomens. Young infected bees take up nursing duties as usual but soon stop rearing brood because food glands are affected and they shift to foraging. Affected bees have disjointed wings and are found crawling in front of the hive. Large number of spores can be observed in the mid gut contents of infected bees under microscope. The spores when reach midgut, they germinate and vegetative rods multiply in the epithelium and the cells become non-functional; the digestion is impaired. The disease is particularly severe during spring and winter and there is depletion of strength. Combs are contaminated by defecation by discascd bees and the spores are picked up by the hive bees during cleaning and polishing the cells. 
The colony management is important to reduce disease incidence. Wintering with more colony strength, with sufficient stores and open-sunny sites helps overcoming disease incidence.

Sterilization of infected equipment and combs is possible by fumigation with acetic acid which a re left in stacked, airtight hive bodies for one week. Temperature treatment at $49^{\circ} \mathrm{C}$ for 24 hr destroy spores. Fumagillin@10 mg per litre of sugar syrup is best known chemical for the control of the disease but is now not available in market. Other alternatives bave not been evaluated since it is not a serious malady.

\section{FUNGAL DISEASES}

Two fungal diseases, viz., chalk brood (Ascophera apis) and stone brood (Aspergillus flavus) are known in honeybees. Incidence of both is very minor and there cannot be any problem in well attended apiaries because incidence is there under cool and damp conditions. The brood which remains unprotected by bees in the outer combs is infected by $A$. apis. The larvae are reduced to white mummies and dark spots appear when fruiting bodies are formed. In case of $A$. flavus infection the mummies are hard and not spongy. These fungal diseases have not attracted attention and no methods for control have been worked out. Both the diseases are unknown to Indian apiculture.

\section{MITES}

Honeybees are infested by endo- and ecto-parasitic mites and some phoretic mites bave also been observed in bee hives.

\section{Acarapis woodi}

Acarapis woodi is an endo-parasitic mite of adult bees. Acarine was first reported from India in 1957 by Singh from Apis cerana indica colonies. Singh and Adlakha $(1957,1960)$ found that $10 \%$ of colonies in Shimla Hills were infested. It is present in north-western states of India. The mite is present in many parts of the world but is absent in temperate and tropical parts of America, Australia and New Zealand. It infests the tracheae of first thoracic spiracle where they suck the baemolymph. The diagnostic symptoms and effects of $A$. woodi infestation are: (1) Bee crawlers are found in front of hive; (2) bees are unable to fly and wings are held disjointed in ' $K$ '. winged condition; (3) life of infested bees is shortened; (4) mites, if present in large numbers in tracheae, binder the intake and supply of oxygen to flight muscles; (5) infected bees are short lived; and (6) mite infestation leads to secondary invasion by viruses. To confirm the presence of acrine the prothoracic collar is removed to expose the largest trachea and observed under microscope. Mites in all developmental stages are observed and tracheae become dark due to punctures made by mites and also because of accumulation of faeces.

Female mites enter the tracheae of young bees. Because of developing of 
a hair barrier the mites cannot enter after the bees are more than 9 days o!d. Female lays 5-7 eggs which batch in 3-4 days and it takes 6-10 days to reach adult stage. They mate inside the tracheae and mated females migrate through body hairs to other bees. Mite spread through drifting or by beekeepers when they transfer diseased bees to a healthy colony while uniting them.

Folbex (chlorobenzilate) fumigation is the tested control method for the endo-parasitic mites. In India also Atwal (1971) recommended 5-7 fumigations with Folbex strips at weekly intervals. Adlakba (1976) reported that methyl salicylate and menthol were ineffective. Mixture of nitrobenzene + methyl salicylate and petrol was effective but it induced severe, uncontrollable robbing and a lso damaged the brood. In the event of non-a vailability of Folbex strips and chlorobenzilate, other control measure were also evaluated. Formic acid, $5 \mathrm{ml}$ of $85 \%$, was found effective against the mite and the colonies cleared of infestation in a fortnight. The chemical had no adverse effect on the broud or on the longevity of the adult bees (Sharma et al., 1982). Menthol strips (300 $\mathrm{mg}$ per strip) were found to be effective for the control of the mite(Kshirsagar et al., 1980) but Garg and Sharma (1988) achieved partial control of the mite with menthol and they suggested its use as prophylactic measure like methyl salicylate.

Three species of Acarapis, viz. A. vagans, A. externus and $A$. dorsalis, a re ecto-parasitic mites but they have not been encountered in India and elsewhere also the incidence is rare.

\section{Varroa jacobsoni}

The mite has caused serious concern for beekeeping in Europe, particularly to the queen rearing yard of $A$. mellifera. This brood mite, though reported on Indian honeybee from India but is of no major concern. A. cerana is the original host of $V$. jacobsoni but the mite and bee have developed mutual adaptation. The mite was first reported by Phadke et al. (1966) from Delhi (India). Reports from other parts of the country were also published (Gupta, 1967; Pandey, 1967; Punjabi and Saraf, 1969; Rangarajan, 1971). Apis mellifera in other countries is believed to become contaminated through close contact with Apis cerana and is now spread to eastern Europe because of movement of bees. In India also the mite is recently reported from Apis mellifera colonies (Kumar et al., 1988) but within last 30 years it has not caused serious damage even to mellifera colonies.

Female mite enters the cell of 5 to $5 \frac{1}{2}$ days old larva, that is just before sealing and lays 2-5 eggs on the walls of the cell. Larva develops in the egg in $24 \mathrm{hr}$ and moults to protanymph which batches after $48 \mathrm{hr}$ after the egg is laid. The developing stages feed on haemolymph of the larva/pupa and total developmental period is 6-7 days for male and 7-8 days for females. Adult female mite lives on adult workers and drones; commonly found on the abdomen under the abdominal sclerites. They feed by making boles in the intersegmental membrane. Adult male is spherical and yellow in colour and female is reddish-brown and pilose with long setae on the dorsum. Brood cells should be opened to remove the pupae with foreceps for ascertaining 
the infestation. Bees can be sampled; shake them in glass jars and pass the filtrate through white cloth where mites can be seen. Dead mites can also be observed on the bottom board in the debris.

Infested colonies are weakened. The brood fails to develop into adults or malformed adults are formed. Drone brood is more prone to attack but worker brood is also affected. In queen rearing and mating yards the Varroa infestation causes shortage of drones for mating.

Control. The mite parasite control has been discussed by Ritter (1981) and De Jong et al. (1982), though no work has been conducted in India. Synecar, a mixture of sugar powder + chloropropylate or bromopropylate @50 to $100 \mathrm{mg}$ per colony, depending upon the strength, is dusted in passages between the frames. Thymol $0.25 \mathrm{~g}$ powder dusted in passages of frames is effective and it is also slightly effective when used as an evaporation agent. Formic acid placed in the empty hive space is effective. The rate of evaporation is controlled by the length of the wick in the bottle. Phenothiazine smoke (2-4 g per colony) directed into the hive and the entrance then closed for 5 min has been found to give $70-80 \%$ kill. Systemic acaricides like Chlorodimeform hydrochloride fed to bees goes to blood stream and mites get knocked down when feed on haemolymph.

\section{Tropilaelaps clareae}

Tropilaelaps clareae is another serious ectoparasitic mite of bees. Though its infestation is observed in all Apis spp., yet it is serious on Apis mellifera (Atwal and Dhaliwal, 1969). It was first reported in India from Apis dorsata by Bhardwaj (1968). Serious mite infestation on $A$. mellifera was reported by Atwal (1969) and Atwal and Goyal (1971) observed up to $80 \%$ brood kill in the late larval and pupal stages.

Infested colonies have irregular brood pattern, dead and malformed larvae and pupae in brood combs. Malformed adults with missing or poorly formed wings and shrunken abdomens can be observed crawling around the hive. Adult mites are fast moving on the combs and the transmission to other colonies is through robbing, drifting or by colony manipulations by the beekeeper.

Chlorobenzilate (Folbex) fumigation does not give effective control. Sulphur dusting @200 mg per colony on top bars of frames is very effective (Atwal and Goyal, 1971). Garg et al. (1.984) found that fumigation for 13 days with $5 \mathrm{ml}$ of $85 \%$ formic âcid each day reduces $T$. clareae population without harming the brood and adult bees.

\section{INSEC.T ENEMIES OF BEES}

\section{Wax moths}

The greater wax-moth (Galleria mellonella L.) is a most serious threat to combs. While it is discussed in detail, a brief account of comparatively mino: pest the lesser wax moth Achroia grisella (Fab.) is also given. There are caterpillars of several other moths; the Mediterranean flour moth /Ephestia 
kuhniella (Zell.)], fig moth [E. cautella (Walk.)], Indian meal moth [Plodia interpunctela (Hbn.)] and dried fruit moth (Vitula spp.) are also noticed in combs, but their damage is occasional and they do not occur widely.

\section{Greater wax moth}

Adult brownish-grey, $10-18 \mathrm{~mm}$ length; wing expense $25-40 \mathrm{~mm}$; the female is larger than male. The colour and size of adults vary a great deal in accordance with the food eaten during the larval period; dark-brown combs containing pollen give rise to darker and bigger adults. The outer margins of the fore wings of the male has a semi-lunar notch, whereas that of the female are smooth (Fig. 65).

Egg. Spherical, smooth, creamy-white, 0.4 to $0.5 \mathrm{~mm}$ in size. Eggs hatch in 3 to 5 days at $29^{\circ}-35^{\circ} \mathrm{C}$ but in 30 days at $18^{\circ} \mathrm{C}$.

Caterpillar. Freshly hatched larva is white, full grown larva dirty-grey with brown head. They live in silken tunnels made in mid rib of combs.

Pupa. The young pupa is brownish-white and old is dark-brown; 14-16 $\mathrm{mm}$ long. The cocoons usually form a mass of silken fibres strongly webbed together in rows, sometimes carved in the wooden parts of the hive.

Life history. The males and females mate within a day of their emergence and females enter the hive usually at night when the bees are not active but occasionally during day time in case of weak colonies. Female starts egg laying in clusters in one or two days after mating and lays 300-600 eggs in 4-10 days. Males live for 3-4 weeks. Incubation period of eggs vary with temperature. Eggs hatch in $3-5$ days at $29^{\circ}-35^{\circ} \mathrm{C}$ but in 30 days at $18^{\circ} \mathrm{C}$. The eggs cannot stand temperature below $16^{\circ} \mathrm{C}$ and above $35^{\circ} \mathrm{C}$. Young caterpillars are exceedingly active and eat gnawed pieces of comb. They soon spin silken tunnels in the comb or tubular galleries on the bottom board to protect themselves. If the food on the bottom board is not sufficient, they migrate to the combs and move towards its mid rib. The caterpillars cast off their skin four to six times. The total life cycle may be completed in six weeks to six months. At normal temperature of $29^{\circ}-32^{\circ} \mathrm{C}$ available in the hive during the active season an egg may become an adult in about 7 weeks.

Seasonal history. There are several overlapping generations of the pest in a year depending on temperature; the availability and nature of food and whether the pest is inhabited in hive or stored combs. In localities with comparatively warm winters, all stages of the pest are met with in hives throughout the year. In stored combs, the pest hibernates in caterpillar stage (about 70\%) and in pupal stage (about 30\%). The development even in warm localities is considerably slowed down in winter and the pest is active from March to October.

Nature and extent of damage. The caterpillars eat away combs or damage them by making tunnels in mid rib of combs. The first indication of the entry of the larva in the comb is the presence of small pieces of minute particles of wax outside the holes. Later faint webbings are perceptible over some cells of the comb. When infestation has progressed considerably, silken tunnels with caterpillars wrigling in them are noticed and eventually whole comb is 

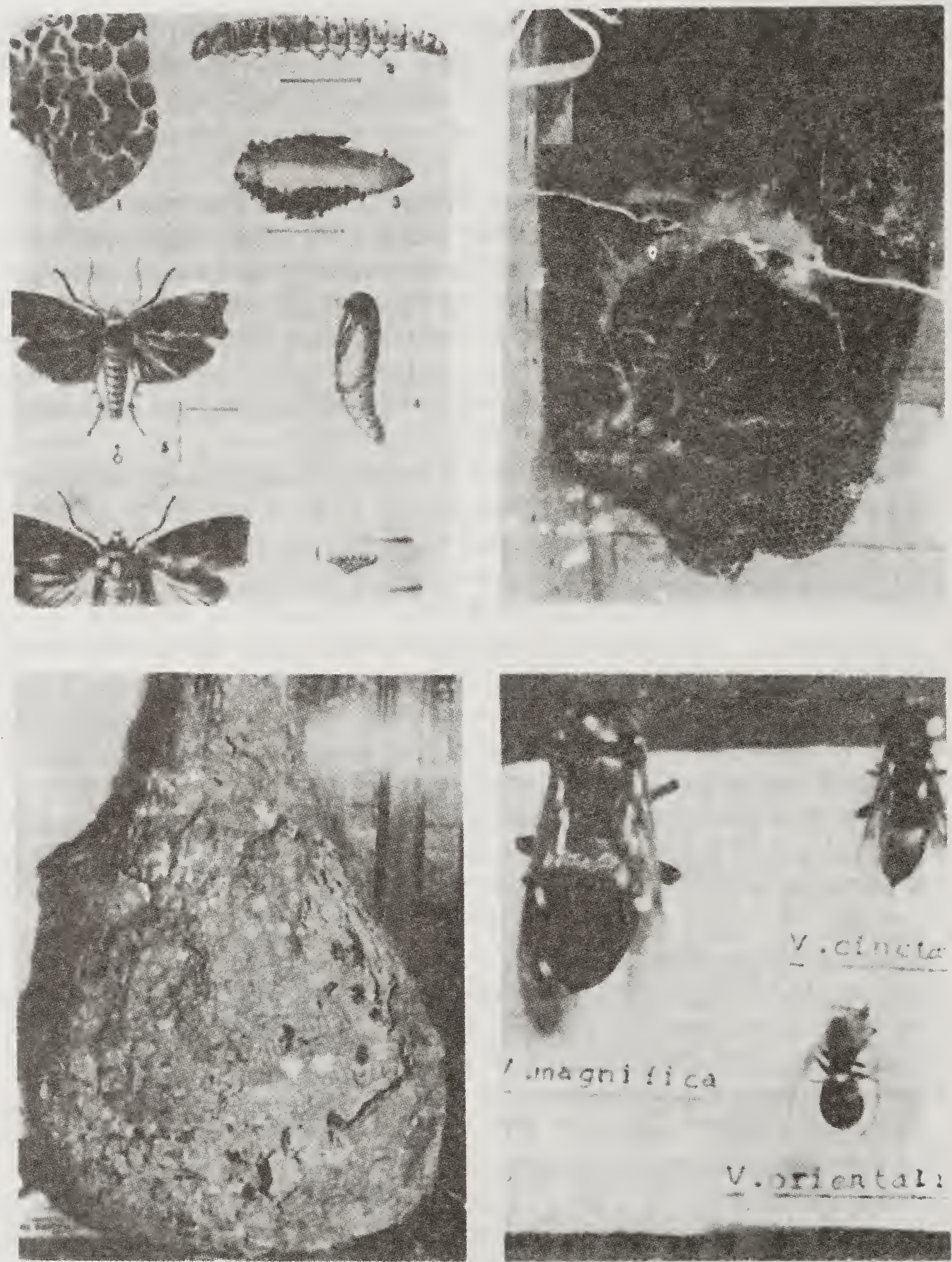

Figs. 65-68. 65. Wax moth (Galleria mellonella). 1, Piece of comb showing eggs, caterpillar and moth in resting position; 2, Caterpillar; 3, Cocoon: 4, Pupa; 5, Male moth; 6, Female moth; 7. Cluster of eggs. 66. Apis florea comb badly infested with wax moth. 67. A nest of predatory wasp. 68. Three serious predatory Vespa species

reduced into mass of webbings in which the excreta of caterpillars is enmeshed. In severe cases the brood rearing is stopped in the colony and bees desert their nest.

Almost all colonies of Apis cerana indica, Apis dorsata and Apis florea are infested with wax moth. Attack of wax moth is very low in Apis mellifera combs because the species is a heavy propoliser which is also incorporated 
in the combs for reinforcement. In the former 3 species the pest acquire dangerous importance during dearth period and the monsoon. Infested colonies, stored combs, improperly cleaned beeswax and wild colonies or deserted combs of $A$. florea (Fig. 66) and $A$. dorsata a re the constant source of infestation.

Prevention and control. Though any colony is prone to the attack of wax moth, strong colonies are able to resist it. The colonies can be helped by keeping the hives without cracks and crevices, Hive entrance should be reduced which can be effectively guarded by bees. It is dangerous to keep extra combs in the hive and removal of all combs which are not covered with bees, especially during dearth period, is strongly recommended under Indian conditions.: During the normal examination of colonies, the debris on the bottom board should be scrapped and cleaned with the hive tool. Tunnels of larvae in the combs can be seen if it is held against the sun rays. The larvae can be killed in the initial stages and silken webbs are cleaned.

Extra combs should be appropriately stored. The combs can be conveniently stacked in hive bodies. The whole stack of $4-5$ hive bodies can be made air proof for fumigation with sulphur by covering the joints with wet clay. The combs so stored are disinfected by sulphur smouldering at $180 \mathrm{~g}$ per one cubic metre of space. Liquid ethylene bromide@20 to 100 g per 1000 litre space is effective for disinfecting combs in polythene air tight bags. Acetic acid fumigation kills eggs and adults but larvae, particularly older ones escape the treatment.

Biological control has been found to be feasible. Battu and Singh (1977) in India found that $16 \mathrm{ml}$ thuricide (formulation with 30 billion spores per $\mathrm{ml}$ of Bacillus thuringiensis) in 4 litres of water sprayed on combs was effective in controlling the pest.

All stages of wax moth are killed in combs at $46^{\circ} \mathrm{C}$ for 70 min or at $0^{\circ} \mathrm{C}$ for $270 \mathrm{~min}$, therefore, temperature treatment is also good method of control.

\section{Lesser wax moth}

The adults, larvae and pupae of this moth a re smaller thain those of greater wax moth. The egg stage lasts for $\hat{2}-4$ days, larval from 34-48 days, pupal from 5-12 days and adults live for about a week. The female moth lays 300500 eggs. There are 3-4 generations during the active season.

The species of wax moth is noticed at comparatively higher altitudes than those where greater 'wax moth is found. Its caterpillars a re more like scavengers as they are usually to be found in the debris. They also attack stored combs and feed on the outer surface. Their webbing is interspersed with dark faecal pellets. They as well as other species of caterpillars which infest combs can be controlled in the same way as the greater wax moth.

\section{Predatory wasps}

Several species (Fig. 67,68) of Vespa, viz. $V$. orientalis (L), V. cincta (F), V. auraria (Smith), V. ducalis (Smith), V.basalis (Smith) and V. magnifica (Smith), are found in plains and hills (Ghosh, 1924; Dave, 1943; Mutto, 
1949; Kshirsagar and Mabindre, 1975). They are social insects and build paper nests in cavities of trees, walls, or hang them down from tree trunk. $V$. cincta and $V$. magnifica are soil nesting species. They a re predaceous by nature and feed on bees and other insects. They catch the prey from the flowers or some species catch bees from the hive entrance; and others are bold to enter a hive to catch their prey from the combs. Wasps macerate bees and feed their young ones on a paste like material.

Fecundated female wasps overwinter and start new nests in spring. This female does all the work in the nest and also collect food for herself and the young ones. The worker wasps on emergence help their mothers and take over the nursing duties and field work. The nest becomes populous during the monsoon and autumn. The nest population is at its peak during autumn, at the end of which all castes except fecundated females die out. They overwinter in nooks and crevices and start nests in the following spring.

For the control of these predatory wasps many methods have been tested. Killing a fecundated female during spring means destroying a future colony. The nests of wasps in the vicinity should be located and destroyed by burning with kerosene torches or by spraying/dusting insecticides. Elimination of alighting boards at the hive entrance has been recommended by Subbiah and Mahadevan (1957). Kshirsagar (1971) designed a wasp trap (Fig.69) in which wasps were attracted to a bait but they did not find a way out. The trap is partially effective. Sharma et al. (1979) reported that flapping reduced the wasp attack for sometime. They also evaluated poisoned baits and other methods for the control of the wasps and inferred that none of the single method gives satisfactory control but a combination of methods is required to avoid losses to bee colonies.

\section{Black ants}

Various species of black ants, viz. Camponotus compressus (Fab.) Monomorium indicum Morell. and $M$. destructor (Ters.) intrude bee hives and take away honey and pollen. They are more troublesome to weak colonies but strong ones usually succeed in keeping them at bay. As black ants live in underground nests, the colonies can be destroyed by fumigating them with some fumigant or by pouring $0.1 \%$ emulsion of Aldrin and sealing them with mud. Bee colonies can be saved from intrusion of ants by placing the hives on stands with their legs in earthen pots containing water. Tape soaked in corrosive sublimate and wound round the legs of stands is a good repellent but needs renewing once or twice a week.

\section{BIRDS AND OTHER ENEMIES}

King crows [Discrurus macrocercus (Vielillot) and D. ater (Nerm.)] occasionally visit apiaries on cloudy days and prey upon bees. Otherwise they are friends of farmers. The bee eater Merops orientalis, (Latham) (Fig.70) and $M$. supercilosus (L.) do much harm in apiaries. From ' 6 to 43 honeybees have been. found in the stomach of a bird of these species. Attack by these 


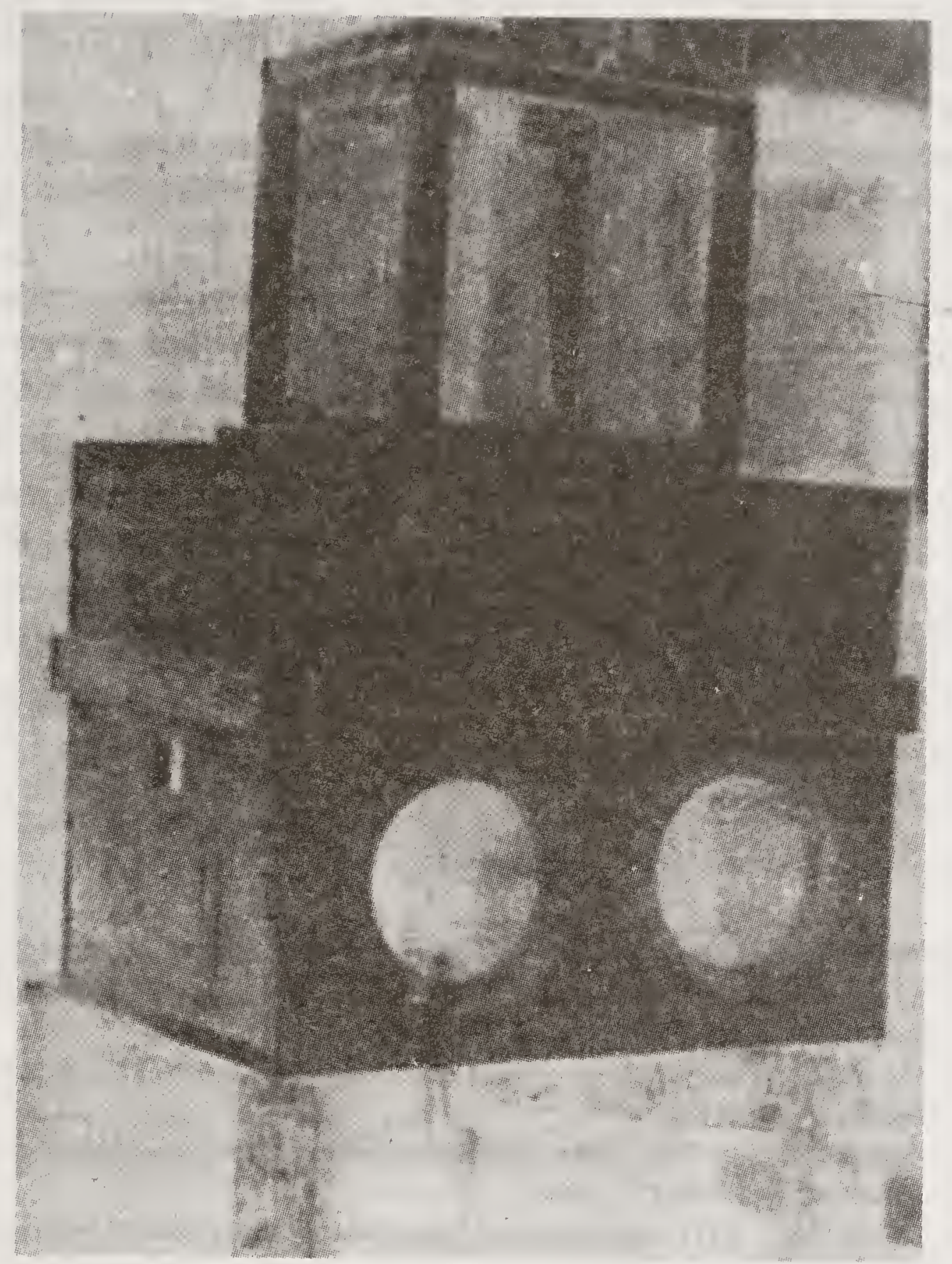

Fig. 69. Wasp trap.

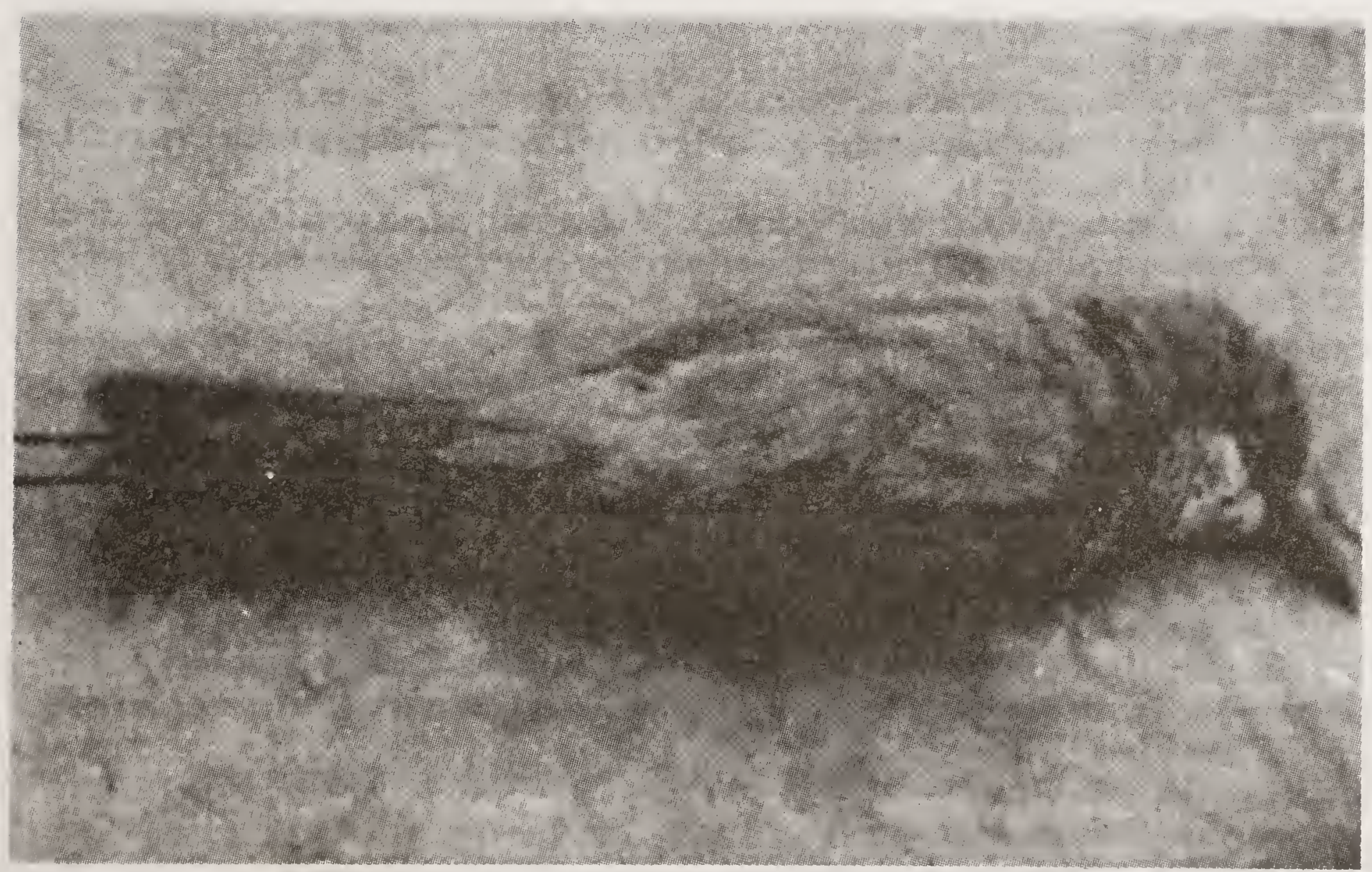

Fig. 70. Bee eater (Merops sp.), a dangerous bee enemy in apiaries. 
birds is most severe in summer and monsoons. They sit on trees or telegraph wires near apiary and pick the bees on wings. These birds are also very useful in keeping down the insect population of a locality and keeping in view the environmental-ecological balance, no large scales measures against them can be recommended. Scaring them away from apiaries is suggested.

In India, besides the above enemies there are some other enemies which have been recorded. Rao et al. (1972) observed that preying mantis (Odontomantis micans) a predator of honeybees waited on the flower heads and inflorescences of coconut and caught the worker bees as they foraged. The spider Nuphilia kuhlii made webs on shrubs during monsoon and autumn, and trapped foragers in the web (Thakur and Sharma, 1984). Rangarajan (1964) found Protaetia aurichalcea F. feeding on pollen in brood combs of Apis cerana indica. P. impavida and Anomala dimidiata also feed on stored pollen in Apis mellifera and Apis cerana indica hives in Himachal Pradesh (Hameed and Adlakha, 1973).

\section{REFERENCES}

Adlakha, R.L. 1976. Acarine disease of adult honeybees in India. Am. Bee J. $116(7):$ 324-44.

Atwal, A.S 1969. Serious infestation of Apis mellifera L. bees by the ectoparasitic mite, Tropilaelaps clareae. 22nd Int. Beekeep. Congr. Summary 108 only.

Atwal, A.S. 1971. Acarine disease proplem of the Indian honeybee, Apis indica F. Am. Bee J. 111: 134-36, 196-87.

Atwal, A.S. and Dhaliwal, G.S. 1969. Some behavioural characteristics of Apis indica F. and $A$. mellifera L. Indian Bee J. 31(1) : 1-8.

Atwal A.S. and Goyal, N.P. 1971. Infestation of honeybee colonies with Tropilaelaps and its control. J. apic. Res. $10(3): 137-42$.

Battu, (i.S. and Singh, K. 1977. On the possibility of using Bacillus thuringiensis Berliner against wax moth Galleria mellonella Linn. in bee hives. Indian Bee J. 39(1/4) : 27-29.

Bhardwaj, R.K. 1968. A new record of mite, Tropilaelaps clareae from Apis dorsata colonies. Bee Wld. $49(3): 115$.

Dave. M.L. 1943. Wasps. Indian Bee J. 5: 127-31.

De Jong, D., Morse Roger, A. and Eickwort, George C. 1982. Mite pests of honeybees. Ann. Rev. Ent: $27: 229-52$.

Diwan, V.V., Kshirsagar, K.K., Raman Rao; A.V., Roughunath, D. and Bhambure. C.S. 1971. Occurrence of a new bacterial disease of Indian honeybee, Apis indica F. Curr. Sci. 40(8): 196-97

Garg, R., Sharma, O.P. and Dogra, G.S. 1984. Formic acid, an effective acaricide against Tropilaelaps clareae Delfinado and Baker (Laelaptidae; Acarina) and its effect on the brood and longevity of honeybees. Am. Bee J. 124(10) : 736-38.

Grag, R. and Sharma, O.P. 1988. Efficacy of chlorobenzilate and menthol against Tropilaelaps clareae Delfinado and Baker (Laelaptidae: Acarina) in Apis mellifera L.Indian Bee J.50(3) : $65-66$.

Hameed, S.F. and Adlakha, R.L. 1973: Scarabaeid - a new menace to beekeepers in Kulu Valley. Indian Bee J. 35:48.

Kshirsagar, K.K. 1971. A wasp trap to control predatory wasps in the apiary: Indian bee J. 33:35.

Kshirsagar, K.K and Mahindre, D.B. 1975. Some notes on bee predatory wasps in India. Indian Bee J. 37(1/4): 4-9.

Kshirsagar, K.K., Salvi, S.R., Mahindre, D.B. and Chauhan, R.M. 1980. Menthol as an effective acaricidal fumigant. Proc. 2nd Int. Conf. Apis. Trop. Climates, New Delhi, 254-56.

Kshirsaga r, K.K., Sexena, U.C. and C.hauhan, R.M. 1982. Occurrence of sac brood disease in Apis cerana indica F. in Bihar, India. Indian Bee J. 44(1) : 8-9. 
Kumar, J., Gupta J.K. and Dogra, G.S. 1988. Discovery of the ectoparasitic mite Varroa jacobson ; On Apis mellifera L. in Himachal Pradesh, India. Am. Bee.J. 128 (2): 124.

Mutto, R.N. 1949. Causes of low honey yields in India. Indian Bee J. 11(11/12) : 124-32.

Phadke, K.G. Bisht, D.S. and Sinha, R.B.P. 1966. Occurrence of mite, Varroa jacobsoni Oudemans in the brood cells of honeybee, Apis indica F. Indian J. Ent. 28; 411-12.

Rangarajan, D.V. 1964. Protaetia aurichalcea F. (Cetonidae), A new beetle feeding on stores of Apis indica F. Indian Bee J. 26(2) : 26.

Rao, P.V.S., Mohansundram, M. and Subramaniam, T. R. 1972. Odontomantismican Stel. (Mantidae: Dictyoptera) as an enemy of Apis indica F., the Indian honeybee in Coimbtore. Indian Bee J. 34(3/4): 72 .

Ritter, Wolfgang. 1981. Varroa disease of the honeybee, Apis mellifera. Bee Wld 62: 141-53.

Sharma, O.P., Grag, R. and Dogra, G.S. 1982. Efficacy of formic acid against Acarapis woodi (Rennie). Indian Bee J. 45(1): 1-2.

Sharma, P.L, Dogra, G.S. and Mishra, R.C. 1979. Evaluation of methods of control of predatory wasps, Vespa spp, in a piaries. Indian Bee J. 41(3/9): 10-16.

Singh, S. 1957. Acarine disease in the Indian bee (Apis indica F.) Indian Bee J. 19(3/4) : 27-28.

Singh. S. 1961. Appearance of American foul brood disease in Indian honeybee (Apis indica Fabr.). Indian Bee J. 23(7/9) : 46-50.

Singh, S. and Adlakha, R.L. 1958. Acarine disease of adult honeybee. Indian Bee:J. 20(6): 64-78.

Singh, S. and Adlakha, R.L. 1960. Survey of acarine disease of adult honeybees in Simla hills. Indian Bee J. 22(1/3) : 3-6.

Subbiah, M.S. and Mahadevan, V. 1957. Vespa cincta Fab., a predator of honeybee and its control. Indian J. Vet. Sci. 27 : 153-54.

Thakur, A.K. and Sharma, O.P. 1984. The spider as bee enemy. J. Bombay nat. Hist. Soc. $81(1)$ : 208-11. 


\section{BEEHIVE PRODUCTS}

HONEYBEES in India are known mainly for the production of boney and to some extent as wax producers (Fig.71). Other valuable beehive products such as pollen, royal jelly, bee venom and propolis are little known; neither produced nor used. The production and uses of hive products are discussed here.

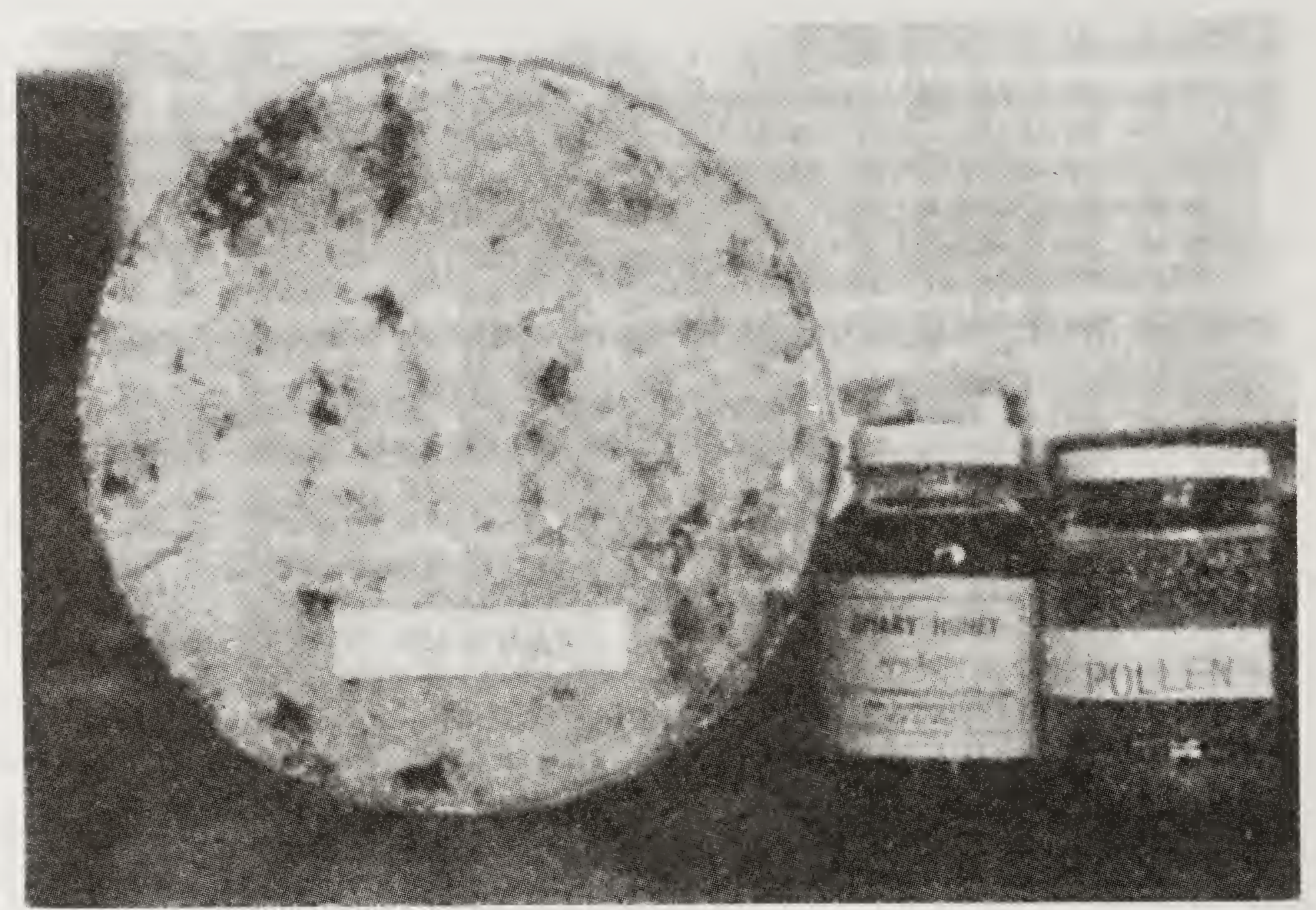

Fig. 71. Hive products; heeswax, honey and bee-collected pollen.

\section{Honey}

Honey is a sweet, viscous liquid produced by honeybees mainly from nectar of plants. Bees also collect sweet exudates of insects 'boney dew' and it is like flower nectar. Some plants also have nectaries other than on flowers. These-nectaries also secrete sweet liquids and bees do avail this extrafloral nectar. Besides, bees can collect any sweet material like fruit juices, cane juice etc.

Depending upon the source of sweet liquid and also the plant species in case of floral and extrafloral nectar, the quality of honey varies. On this basis the honey can be classified as floral honey or honeydew honey. Though monofloral honeys are not common, yet honeys can be categorized on the basis of floral source such as litchi honey, berseem honey, eucalyptus honey, Brassica honey etc. It is also customary to name the boneys on the basis of 
colour. Honey is extracted and prepared for market by different methods. The honey from Apis dorsata combs is squeezed and it is ought to contain more pollen grains and even the juices of some brood and the honey is normally called squeezed honey. The honey from combs of hive species is extracted with the help of honey extractors, so it is extracted honey. These honeys may remain in liquid form or may crystalize, and, hence, can be presented to consumers as liquid honey or granulated honey. There are some other preparations for marketing honey which are not common in India. Small combs can be made to be raised and sealed honey in these combs is marketed as such as comb honey. Small pieces of combs are suspended in liquid honey packing and the preparation is marketed as chunk boney:

Composition of honey. Chemical composition of honey is very complex. Honey mainly contains sugars but acids, minerals, vitamins, enzymes and antibiotic substances are also present in small amounts. The solids in honeys vary with the floral source.

Honeybees, after putting through the ripening process, seal honey (Fig.72) in comb cells when the moisture content is about $20 \%$. The honey in north Indian hot plains have lesser moisture content as compared to honey from Western and Eastern Ghats and areas with very humid climates. In these areas the moisture level in honey can be up to $23 \%$ and honeys are thinner

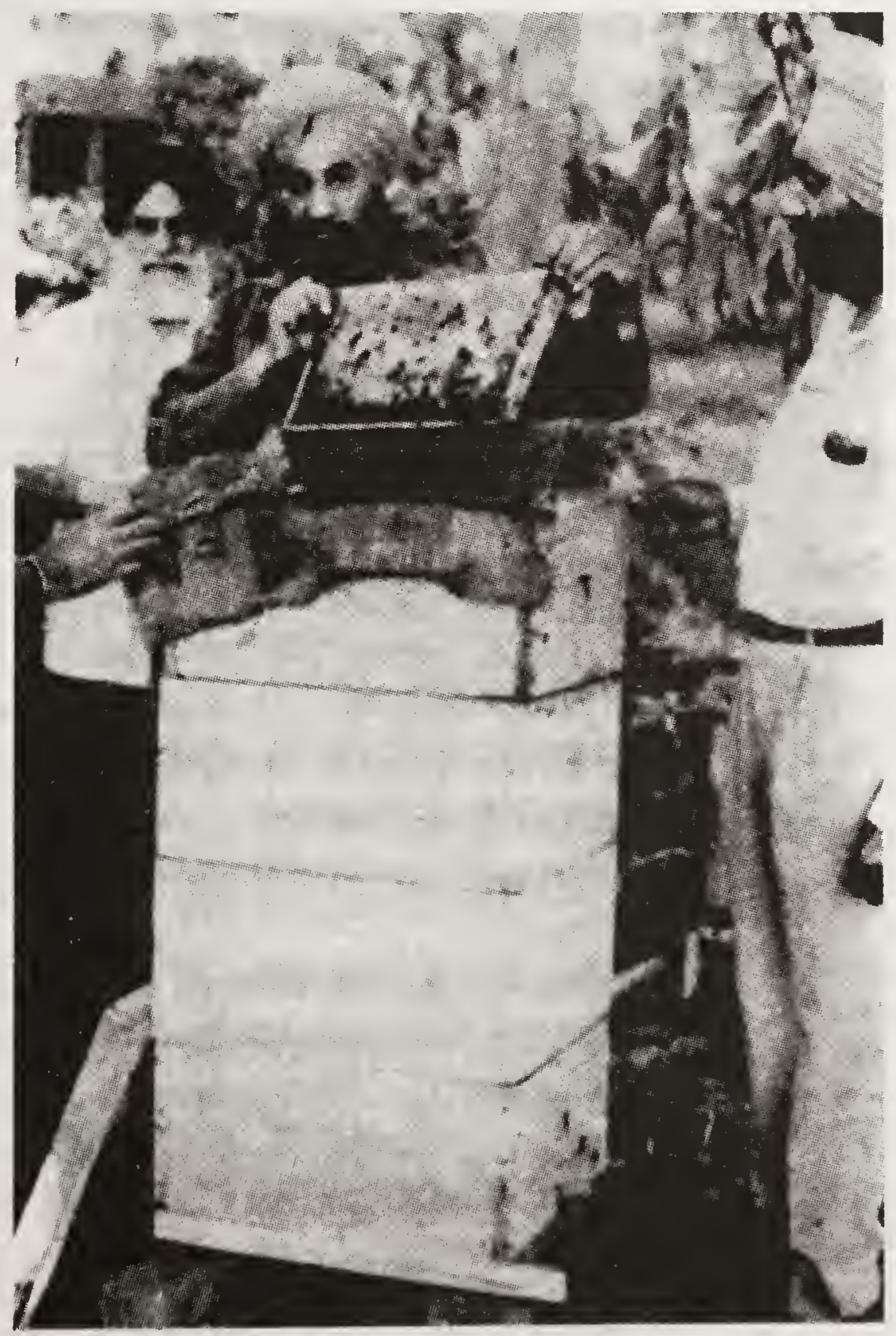

Fig. 72. Apis mellifera colony in four hive bodies. A comb with sealed honey ready for extraction. 
in consistency. The moisture contents may even change after extraction or during storage because honey is hygroscopic and absorbs moisture.

Honey contains many types of sugars but it chiefly consists of 2 reducing sugars, dextrose and levulose (fructose). The 2 sugars account for about $70 \%$ of total solids. Sucrose in honey varies between 0 and $5 \%$. A reducing disaccharide maltose is also present in higher a mount that is $3-16 \%$. This disaccharide may not be present initially but the quantity increases with storage and this probably happens by conversion of other sugars by the action of enzymes and acids. Precise analytical methods have also shown the presence of many other lesser common sugars such as isomaltose, trehalose, genitiobiose, maltulose, panose, turanose, etc. These complex sugars account for $1-2 \%$ only.

Mineral complex of honey is very wide consisting of potassium, calcium, phosphorus, sodium, magnesium, manganese, copper, sulphur, silica, silicon and iron and all these account for up to $1 \%$ of solids in honey.

Different vitamins are present in honey and these are: thiamine $\left(B_{1}\right)$, riboflavin $\left(B_{2}\right)$, nicotinic acid, vitamin $K$, folic acid, biotin, pyridoxine, pantothenic acid, ascorbic acid and carotene. There is loss of vitamins during storage. The losses in thiamine, riboflavin, niacine and ascorbic acid in different unifloral honey is given below (Kalimi and Sohonie, 1965).

Table 9. Per cent loss of some vitamin contents in honey from different sources during one year storage

\begin{tabular}{lcccc}
\hline \multirow{2}{*}{ Source } & \multicolumn{4}{c}{ Per cent loss } \\
\cline { 2 - 5 } & Thiamine & Riboflavin & Niacine & Ascorbic acid \\
\hline Terminalia chebula & 20.5 & 9.0 & 8.0 & 19.00 \\
Riandia dumetorum & 15.5 & 20.0 & 7.3 & 19.20 \\
Syzygium cumini & 17.5 & 16.0 & 9.3 & 15.00 \\
Actinodaphne hookeri & 12.5 & 11.3 & 11.4 & 22.7 \\
\hline
\end{tabular}

Honey also contains the following minor components.

Acids

Amino acids (traces)

Enzymes

Pigments

Flavours and aroma substances
: Tartaric, citric, malic, succinic

: Cystine, aspargin, lysine, glycine, aspartic acid, gluta mic (traces) acid, alanine, tyroxine, valine, methionine, leucine.

: Invertase for conversion of sucrose to simple sugars.

Diastase for conversion of starch to dextrins. Catalase - decomposes hydrogen peroxide. Phosphatase - decomposes glycerophosphate.

: Carotene, chlorophyll, xanthophyll.

: Chemical identification of the individual substances contributing to the flavour of different honeys is very difficult. Apart from sugars, these compounds include amino and other acids (especially 
gluconic); prolline; tannins; glucosidic and alka loidal compounds; also, specifically diacetyl (or other diketoalkane) and methyl anthranilate in orange honey.

In general, iaost pleasing aroma components of honey are those with low boiling points which are most evanescent. But these are lost while extracting honey and in general, components with higher boiling points-including HMF (hydroxymethylfurfural)-seem to be responsible for the characteristic honey aroma.

Inhibine

: Giving anti-bacterial effect.

Physical properties of honey. Besides chemical composition, the physical properties are used to lay down standards for honey. These characteristics also give an inkling of purity of honey.

Honey is hygroscopic, which means it absorbs moisture from air. In areas with high humidity, the honey if not stored properly, tends to draw water from moist air.'This happens in surface layer of honey which increases in moisture content. The hygroscopicity depends upon the sugar composition and moisture in honey. Moisture in honey is in equilibrium to particular relative humidity level. For instance $21.3 \%$ moisture in honey is in equilibrium with $66 \%$ relative humidity. The moisture content of honey can be lowered if exposed to air with lower relative humidity. On the contrary the honey can be saved from absorbing moisture and rendering it liable to fermentation by proper storage of honey in very humid areas. Therefore, the hygroscopicity has practical application to the beekeeper.

Honey is a viscous liquid and the viscosity determines the flowability.

Table 10. Average values of multifloral honey from 4 zones of India (Phadke, 1967)

\begin{tabular}{lcccrr}
\hline & East zone & West zone & North zone & South zone & All India \\
\hline & $\begin{array}{c}\text { (Assam, } \\
\text { W.B.,Bihar) }\end{array}$ & $\begin{array}{c}\text { (M.S. and } \\
\text { Mysore) }\end{array}$ & $\begin{array}{r}\text { (Pb.,U.P. } \\
\text { and J\&K) }\end{array}$ & $\begin{array}{r}\text { (Kerala, } \\
\text { Madras) }\end{array}$ & (Av.) \\
\hline Specific gravity & 1.392 & 1.392 & 1.397 & 1.40 & 1.399 \\
Direct polarization & $-2^{\circ} 6^{\prime}$ & $-1^{\circ} 9^{\prime}$ & $-1^{\circ} 9^{\prime}$ & $-3^{\circ} 27^{\prime}$ & $-2^{\circ} 20^{\prime}$ \\
Moisture (\%) & 21.46 & 20.96 & 19.98 & 20.34 & 20.89 \\
Total diss. solids (\%) & 76.81 & 76.87 & 77.50 & 78.19 & 77.57 \\
Reducing sugar (\%) & 68.91 & 69.97 & 72.78 & 72.88 & 70.24 \\
Non-reducing sugars (\%) & 3.19 & 3.97 & 2.01 & 1.99 & 3.27 \\
Levulose (\%) & 36.01 & 36.72 & 38.04 & 38.77 & 36.48 \\
Dextrose (\%) & 32.31 & 33.00 & 35.03 & 34.07 & 33.39 \\
L/D ratio & 1.136 & 1.120 & 1.084 & 1.137 & 1.097 \\
Dextrins (\%) & 2.050 & 1.960 & 2.025 & 1.771 & 1.966 \\
Acidity (\%) & 0.189 & 0.180 & 0.174 & 0.159 & 0.180 \\
Ash (\%) & 0.210 & 0.175 & 0.196 & 0.157 & 0.187 \\
Proteins (\%) & 0.603 & 0.531 & 0.485 & 0.527 & 0.556 \\
Undetermined (\%) & 2.399 & 2.011 & 2.149 & 1.875 & 2.184 \\
\hline
\end{tabular}




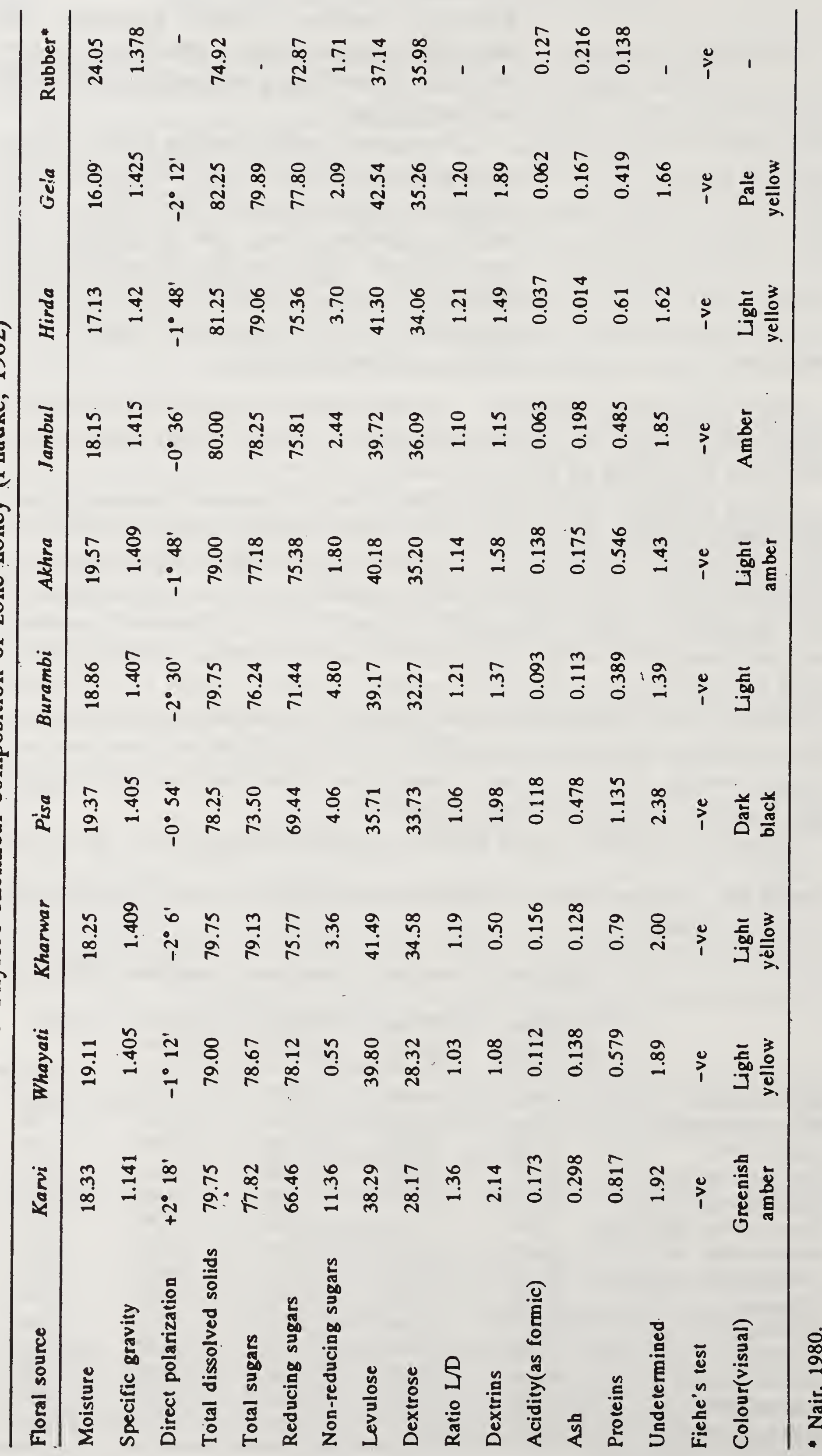


BEEHIVE PRODUCTS

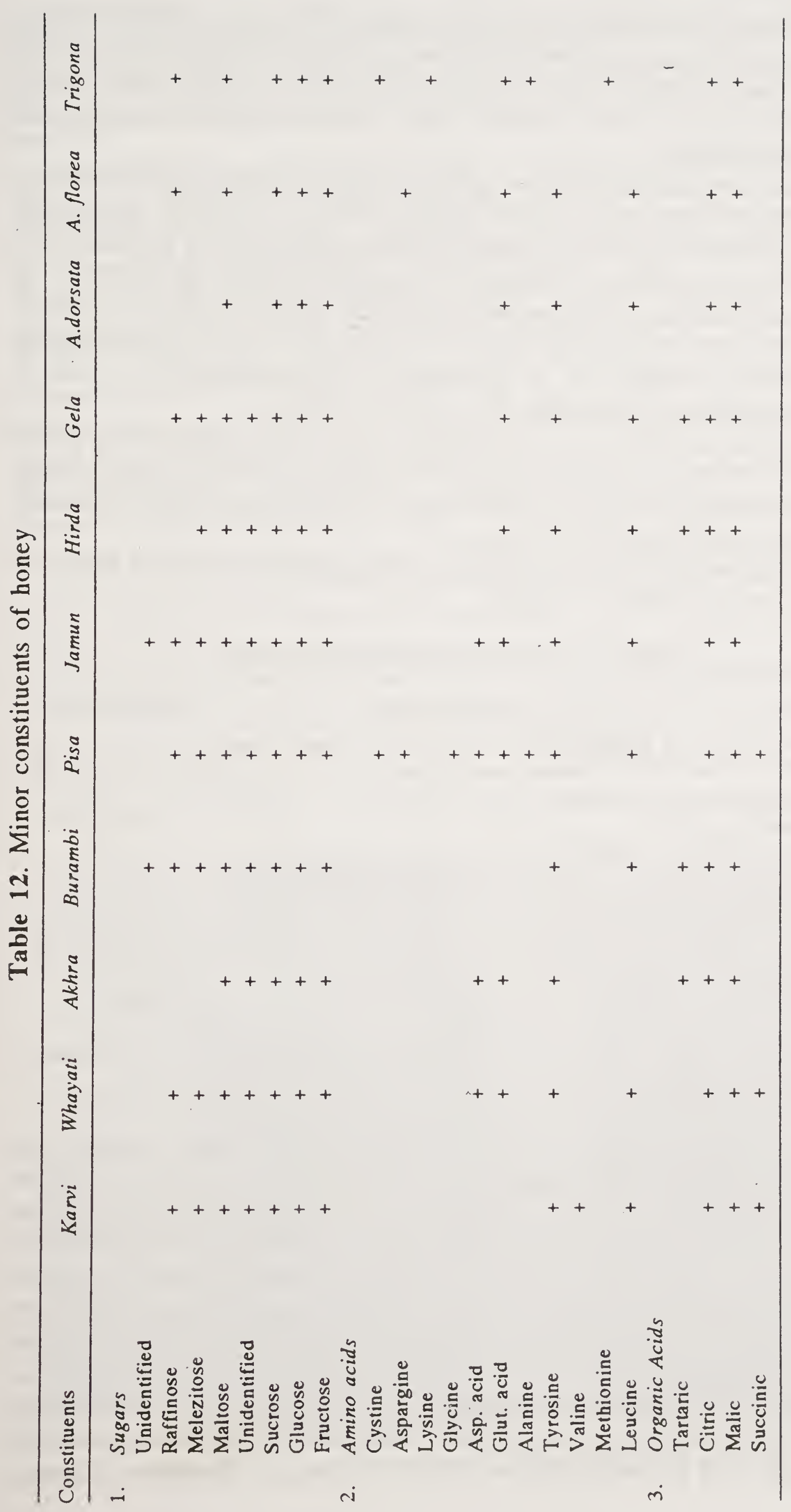


Measurement of viscosity can be used to determine moisture content. Heating reduces the viscosity thus the heat tretment is given to handle honey. But in addition, the viscosity is also dependent on the protein contents which in turn is dependent on the source of nectar. Honey with higher protein contents tend to be more viscous.

Specific gravity and refractive index are other important properties. Ratio of weight of honey to the weight of same volume of water is the specific gravity of honey. Pure honey should have the specific gravity of about 1.351.44. There are different methods of measuring specific gravity but it is customary to specify the temperature. Similarly refractive index of honey is the ratio of the velocity of light in honey to that in air. By using refractometers the moisture in honey can be determined. The measurement of these 2 properties gives quick readings for moisture content.

Honey has specific aroma and flovour. This aroma is imparted by nectar of flowers which is an important physical property for judging honey. Honey has also an ability to acquire foreign odours, so an improper storage containers can impart some metallic flavours.

Purity standards have been laid for both apiary and squeezed honey by Indian Standard Institution (1969).

Table 13. I.S.I. specifications for honey

\begin{tabular}{|c|c|c|c|c|}
\hline \multirow{2}{*}{ Property } & \multicolumn{3}{|c|}{ Apiary honey } & \multirow[t]{2}{*}{ Squeezed honey } \\
\hline & Special grade & A grade & Normal grade & \\
\hline $\begin{array}{l}\text { Specific gravity } \\
\text { (minimum) }\end{array}$ & 1.41 & 1.39 & 1.37 & 1.37 \\
\hline $\begin{array}{l}\text { Moisture per cent } \\
\text { (maximum) }\end{array}$ & 20.0 & 22.0 & 25.0 & 25.0 \\
\hline $\begin{array}{l}\text { Reducing sugars } \\
\text { (minimum) }\end{array}$ & 70.0 & 65.0 & 55.0 & 65.0 \\
\hline $\begin{array}{l}\text { Non-reducing sugars } \\
\text { (maximum) }\end{array}$ & 5.0 & 5.0 & 5.0 & 5.0 \\
\hline $\begin{array}{l}\text { Pollen count } \\
\text { (per gram) }\end{array}$ & - & - & - & 50,000 \\
\hline $\begin{array}{l}\text { Ash per cent } \\
\text { (maximum) }\end{array}$ & 0.5 & 0.5 & 0.5 & 0.5 (min) \\
\hline
\end{tabular}

Fermentation of honey. Honey containing higher moisture content can ferment. This more often happens in case the boney crystallizes and the crystallization is not uniform. The honey granulation starts from the bottom and the dextrose crystallizes forming solids at the bottom. The upper layer of honey becomes dilute with lower sugar concentration. There are many species of osmophilic yeasts in honey and these sugar tolerant yeasts are responsible for honey fermentation. Fermentation of honey is very common at the temperature between $11^{\circ}$ and $21^{\circ} \mathrm{C}$ and the tendency to ferment is reduced at lower and higher temperatures. Fermentation of honey leads to the formation of alcohol and carbon dioxide. The alcohol may further be converted into acetic acid and water; the chain will continue and the whole of honey 
in the container is fermented. Fermented honey is sour in taste because the acidity is as high as $1.5-3.1$ milli equivalents. Heating honey to $64^{\circ} \mathrm{C}$ for about $30 \mathrm{~min}$. destroys yeasts in honey and thus the fermentation is prevented. There are no chances of honey fermentation if it granulates uniformly and quickly.

Crystallization or granulation of honey. Granulation (Fig.73) of honey is the greatest problem for Indian beekeeper. The granulation is considered to be an indication of impurity or adultration in honey and granulated honey is not acceptable to the consumers. Granulated honey is a lso difficult to handle. Some honeys granulate soon after extraction but some do crystallize even when in combs and this has been observed to happen in Brassica honey when combs remain partly uncovered by bees. This makes honey extraction impossible and such combs are good only for feeding colonies in dearth period. The consumers do not understand that honey is a super-saturated sugar solution. The major sugars in honey are fructose and dextrose. Dextrose has the tendency to crystallize and because of this the honey has a natural property to granulate. Fructose is more soluble in water than glucose, therefore, moisture content of honey also contributes to the granulation of honey.

Fructose is to glucose ratio gives an indication of rapidness with which the honey granulates. The honey which has higher ratio of $\mathrm{L} / \mathrm{D}$ will granulate slowly. C'arvia callosa (Wall) Brenek honey contains $38.29 \%$ levulose and $28.17 \%$ dextrose, giving $L / D$ ratio of 1.43 which never gra nulates. In case of Strobilanthes ixiocephalus honey the ratio is 1.038 and the honey granulates quickly. But this ratio cannot give correct indication of granulating property because in Syzygium cumini (jamun) boney ratio is 1.10 but the honey does not crystallize. Therefore, it is not only the $\mathrm{L} / \mathrm{D}$ ratio which is important but

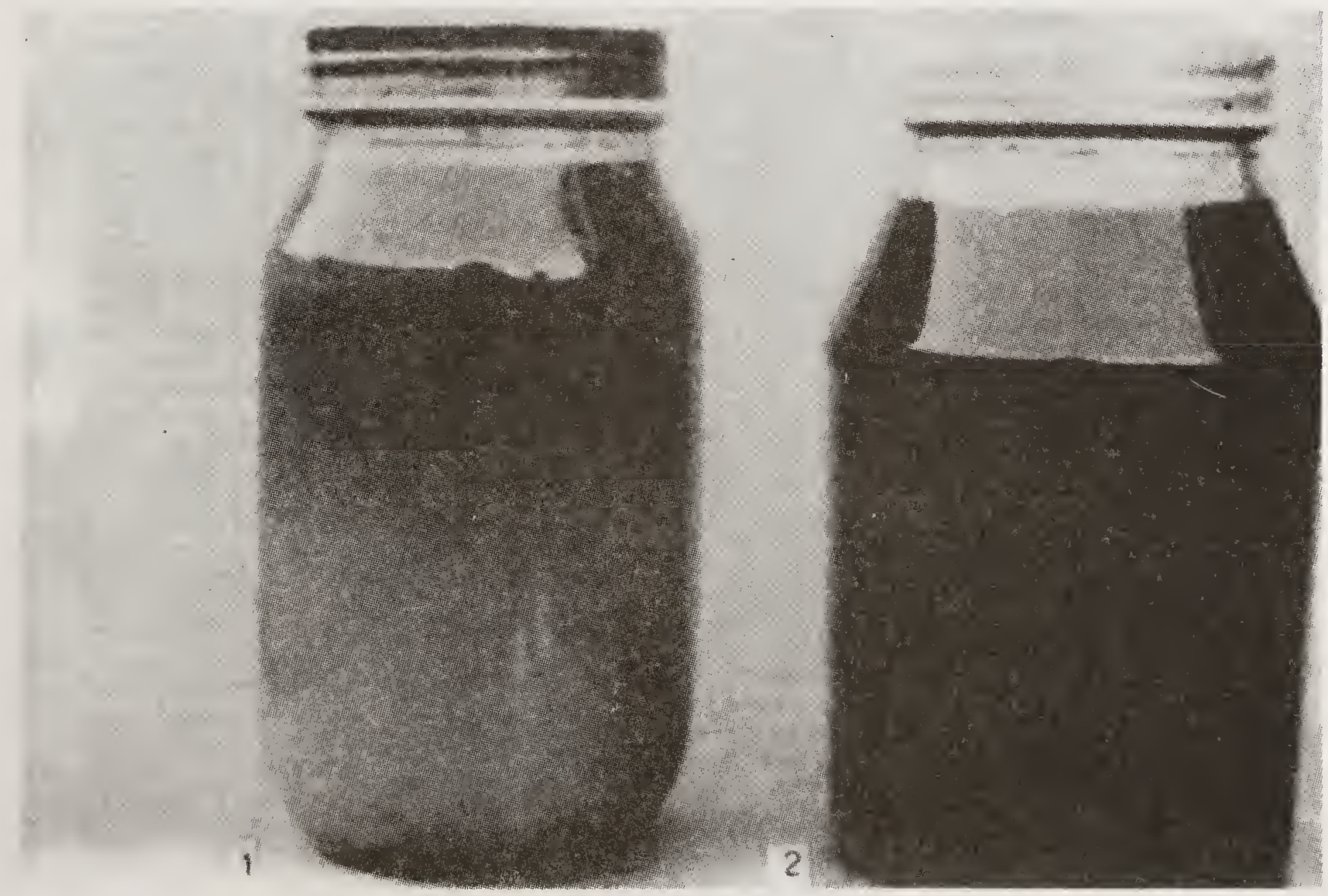

Fig. 73. Two packings of honey. 1. Almost granulated. 2. Liquid. 
there seem to be other factors effecting crystallization. Recently, dextrose (D) is to moisture ratio (W) has been considered to give more accurate indication of granulation. Honey with higher $\mathrm{D} / \mathrm{W}$ ratio is expected to granulate rapidly but this also does not hold good in all the cases and again the exception is jamun honey. But the two criteria are enough for generalization.

Any foreign particles like pollen grains, dust particles and pieces of wax serve as nuclei for granulation and even air bubbles serve the same purpose. The granulation starts around these nuclei.

Honey may granulate uniformly and rapidly. In such cases the granules are fine and there are little chances of fermentation of honey. But some honeys granulate slowly in which case the crystals fuse into bigger lumps leading to coarse granulation. The bottom layers in the container granulate, whereas the top honey layer is still in liquid form. The top liquid layer becomes dilute and fermentation occurs.

Heating of honey destroys yeasts in honey and all dextrose granules are dissolved, therefore, granulation is delayed. The crystallization is also reduced at low temperature between $0^{\circ}-5^{\circ} \mathrm{C}$. The optimum temperature for crystallization is about $14^{\circ} \mathrm{C}$. This property gives an important clue to beekeepers regarding storage temperature of honey.

Processing of honey. (Fig. 74). Honey in comb cells has desirable flavour and aroma, and has no foreign particles except pollen grains. During extraction and handling for marketing the quality of honey may be deteriorated by the beekeeper himself. During extraction, bits of comb wax are incorporated in honey. The honey is extracted with the help of extractors and it is drawn in

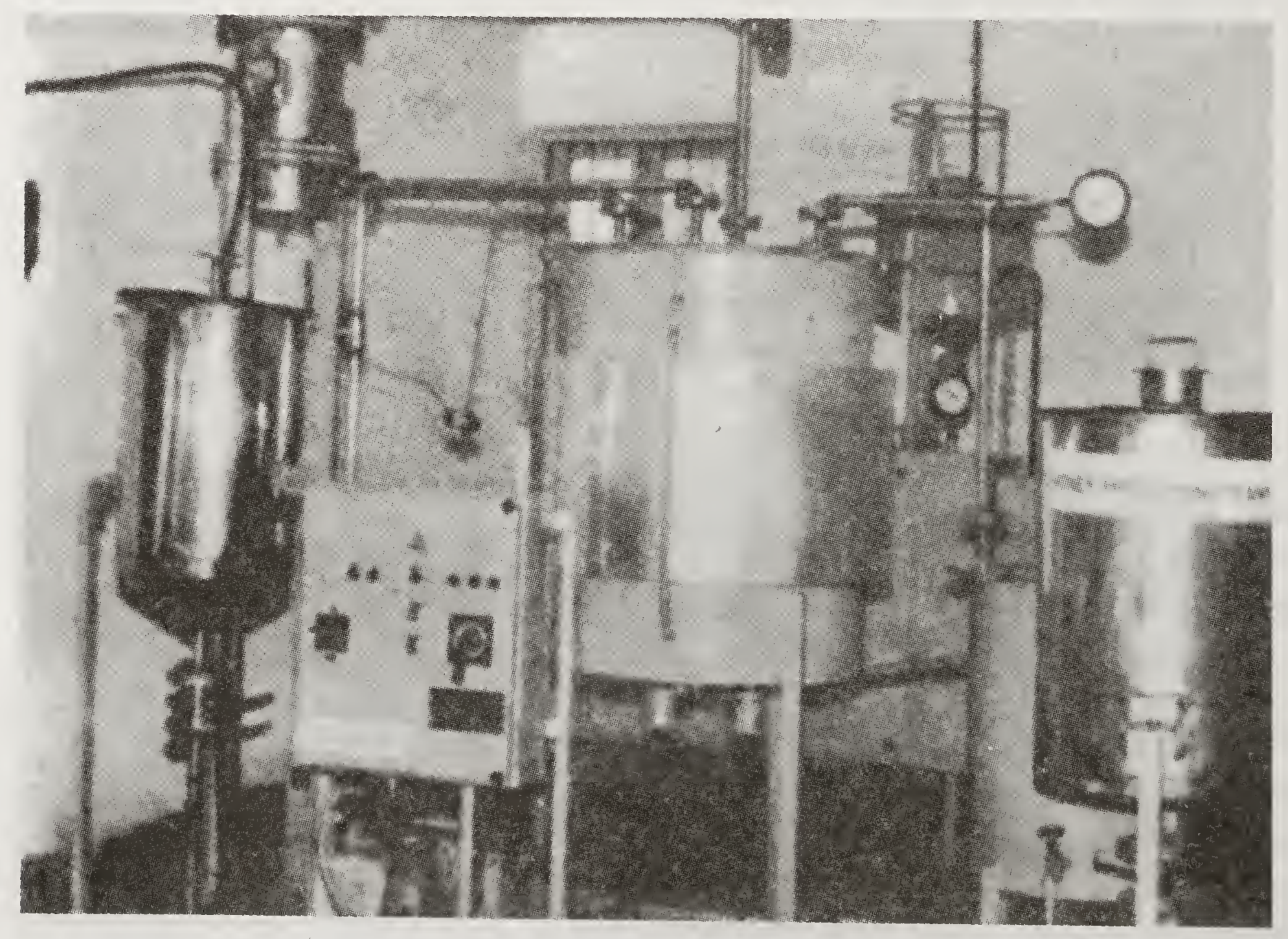

Fig. 74. Honey processing plant. 
thin films from the comb cells, thus some aroma is lost. During extraction some air-borne dust particles may also be added to honey. Faulty storage conditions such as inappropriate containers, high storage temperatures, etc., would further deteriorate the quality of honey. Raw honey is always loved by the consumers but beekeeper wants to put the honey in the market in a best way. But it should be remembered that 'least processing is good processing'.

Honey from different sources vary in physical characteristics and chemical composition. The processing, therefore, depends upon the composition of honey. Some honeys as discussed earlier tend to granulate quickly, whereas others do not or do granulate but slowly. Any attempt to keep the granulating honey in liquid form will be a bad practice, since this will be against the natural properties and such honey tends back to the granulated form. But consumers require the honey that does not ferment and in India crystallized honey is also considered to be impure by most ill-informed consumers. Honey is attempted to be kept in liquid form in India at the cost of losing the valuble aroma.

Heating is the only treatment given for processing honey. But heat treatment if not carefully given can lead to adverse effects. Heat affects honey in many ways which are discussed below:

1. Hydroxymenthyl furfural is produced by degradation of boney sugars. This change also takes place during long storage at comparable higher temperatures but heating is the common reason.

2. Honey enzymes are destroyed by heating.

3. Heating reduces the viscosity, which facilitates handling. To achieve this objective the appropriate temperature to move honey is between $38^{\circ}-43^{\circ} \mathrm{C}$.

4. The treatment is usefully employed to destroy yeasts in honey. This honey if not again contaminated will not ferment. The honey can be made yeast free by heating at $71.1^{\circ} \mathrm{C}$ for $0.4 \mathrm{~min}$ or $65.5^{\circ} \mathrm{C}$ for $2.8 \mathrm{~min}$ or $60.0^{\circ} \mathrm{C}$ for $22 \mathrm{~min}$. Honey needs time to raise its temperature and this time is taken into account for its pasteurization.

5. Honey contains some crystal nuclei of dextrose. These nuclei, when very small may not be apparently visible but they are the cause of crystallization of honey. The heating destroys the crystal nuclei and thus the granulation is delayed, though it cannot be avoided.

Honey is first warmed to $38^{\circ}-43^{\circ} \mathrm{C}$ and this will allow easy flow. This warm honey is then taken to holding tank at about the same temperature. In the holding tank the wax and other foreign particles rise to the surface from where they are removed. The holding tank is provided with paddle type agitator. The paddles are rotated at the speed of $10 \mathrm{rev} / \mathrm{min}$ while it is submerged in honey. The agitation helps in homogenization and blending of honey. The agitator is rotated at a slow speed so that air bubbles are not incroporated in honey. Next in line are the strainers which are provided in series with decreasing mesh sizes and minimum should be around 80 mesh 
per inch. These strainers remove all particles. Any wax particles not removed through straining will give hazy appearance to honey because high temperature $\left(66^{\circ}-70^{\circ} \mathrm{C}\right)$ for pasteurizing will also melt the wax. The strained boney is then passed through a tank to raise the honey temperature to $63^{\circ}-65^{\circ} \mathrm{C}$ for 5-7 min to destroy the yeast. This is achieved by flash heating, that is heating honey in thin layers; it is required because of poor conductivity. The honey so heated is quickly cooled to avoid deterioration of quality. Small scale beekeepers cannot afford to have elaborate processing arrangements; for them warming and straining of boney is only applicable method.

\section{Uses of honey}

Honey as food. Honey contains mainly reducing sugars, some proteins, vitamins and minerals. It is a rich energy-giving food and with milk forms a perfect food. It is highly appreciated as food for infants, the aged and invalid persons. It has been shown that it helps to build haemoglobin of the blood. As it provides energy in a readily available form, honey is largely taken by athletes after or before hard exercise or long races.

In an average Indian home, honey may be used in tea, coffee and milk in place of sugar (Fig.75). Honey-lemon drink is a welcome drink in summer. Honey when used in baking bread, cakes and biscuits, improves their flavour and enhances their keeping quality by retarding their drying up because it is hygroscpic and absorbs and retains moisture. It can be used on fruits, cereals, in salad dressings, canning and preserving.

Honey as medicine. Honey is used as carrier in all Ayurvedic and Unani medicines. Honey is put to countless medicinal uses in Indian homes. Honey is a good laxative, a blood purifier, preventive against cough and cold and

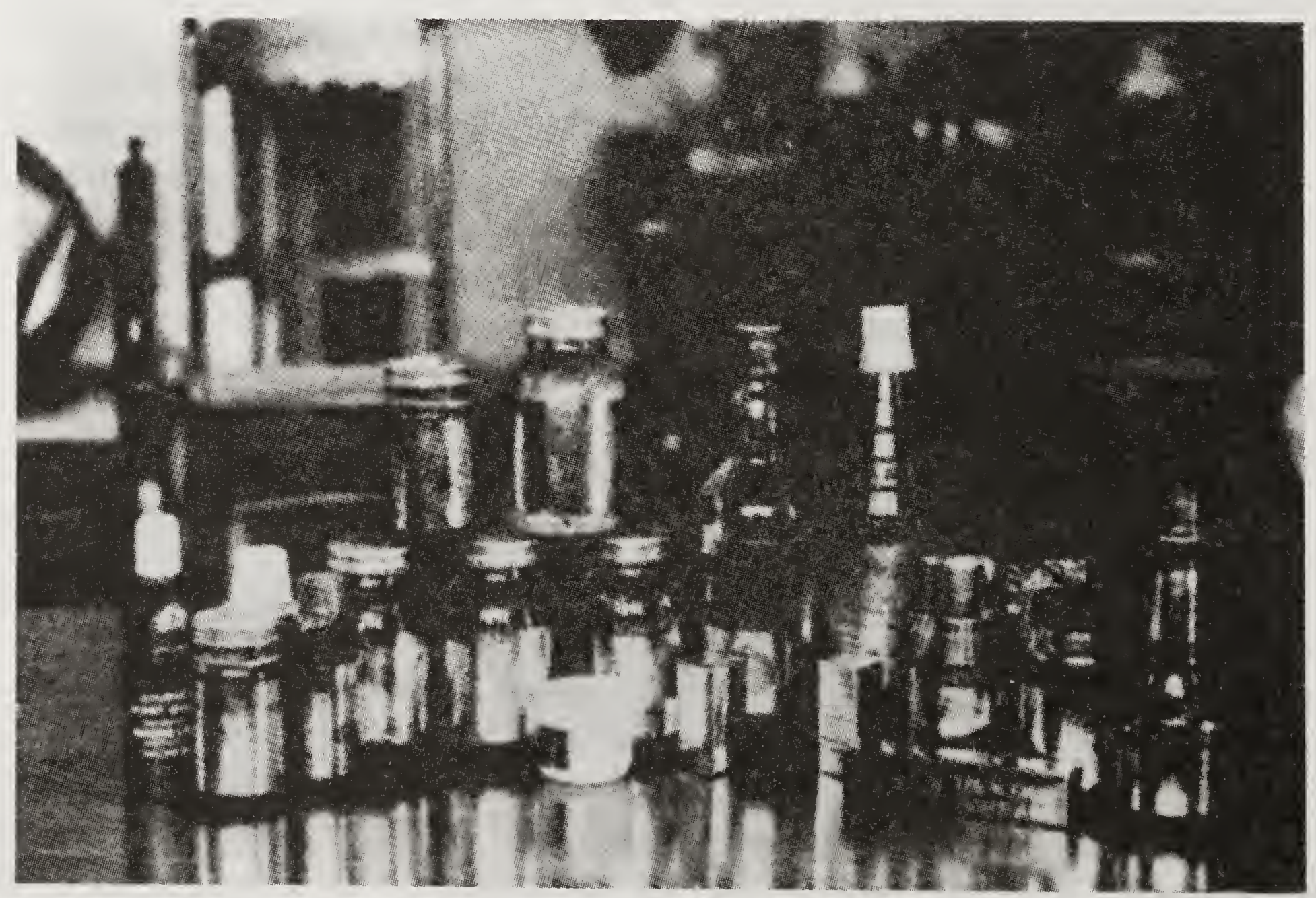

Fig. 75. Honey products: use in food and medicine. 
relieves of sore throat. Honey is a remedy for tongue ulcers. Its regular use is recommended in severe cases of malnutrition with impaired digestion and stomach and intestinal ulcers. A spoon full of honey at bed time is good for insomnia. Honey is also used for curing burns and wounds. Honey lemon juice drink is known to reduce obesity.

Other uses. Honey is made into alcoholic drinks by fermentation, these drinks are popularly known as mead or honey wines. Large amounts are used in skin and beauty lotions. Chewing gums have honey as a sweetening agent. In the laboratory, honey has been found to stimulate plant growth and helps the rooting of cuttings.

\section{Wax}

Worker bees secrete wax when they are 14-18 days old. This is secreted as liquid but solidifies when exposed to air and scales are formed. These scales are removed by hive bees and used for comb building. Wax scales when secreted are white in colour but the colour to wax is imparted by the pigments of pollen. Beeswax is a complex substance (Phadke et al., 1971). Complex esters of monoatomic alcohols and fatty acids form 70.4 to $74.7 \%$ of wax; other components are, free acids 13.5 to $15.0 \%$ and saturated hydrocarbons $12.5-15.5 \%$. It is rich in vitamin A and $100 \mathrm{~g}$ contain $4096 \mathrm{I} . \mathrm{U}$. Specific gravity of beeswax is 0.95 and melting point is $65^{\circ} \mathrm{C}$. There are slight variations in properties of waxes of different species (Phadke and Phadke, 1975).

Table 14. Physico-chemical characteristics of Indian beeswax (average of 6 samples)

\begin{tabular}{lccc}
\hline Characteristics & A. cerana indica & A. dorsata & A. florea \\
\hline M.P. $\left({ }^{\circ} \mathrm{C}\right)$ & 65.82 & 60.67 & 63.03 \\
Saponification value & 98.36 & 98.95 & 91.94 \\
Acid value & 8.21 & 8.04 & 6.77 \\
Ester value & 90.19 & 92.55 & 85.17 \\
lodine value & 7.82 & 5.39 & 10.28 \\
Viscosity (centipoises) & & & \\
$70^{\circ} \mathrm{F}$ & 11.85 & 10.22 & 12.67 \\
$80^{\circ} \mathrm{F}$ & 8.78 & 7.20 & 6.93 \\
$90^{\circ} \mathrm{F}$ & 6.55 & 5.32 & 6.86 \\
Refractive index & & & \\
$\quad 80^{\circ} \mathrm{F}$ & 1.44429 & 1.44363 & 1.44501 \\
$90^{\circ} \mathrm{F}$ & 1.43981 & 1.43922 & 1.43983 \\
\hline
\end{tabular}

Processing and rendering. "Beeswax is obtained from the cappings collected during honey extration. Some combs are damaged during honey extraction and wax is also obtained from old combs which become unfit for use. Best grade wax is obtained from cappings and the recovery per cent is also higher. In India, major proportion of wax comes from the combs of Apis dorsata.

There are different methods of collecting wax. The combs or washed cappings can be boiled in water tanks. It is strained through a muslin cloth 
or strainer; the water and molten wax passes through. The wax block is obtained after it solidifies at the top of water. The combs and cappings can be filled in a thick cloth sack. The filled sack is submerged in hot water tank where the water temperature is above melting point of wax. The water is heated to bring it to boilling. The wax after melting is strained out of the sack and solidifies as top layer on cooling of water in the tank.

Hot wax press is used for efficient and large scale rendering. Raw material is placed in sieve and the material is pressed from both sides with water or steel heated plates. The raw material can even be filled in sacks for rendering. The wax melts with hot plates and it drips from the sides.

Solar wax extractor is also common in use and is particularly effective in hot tropical/sub-tropical climates. Solar extractor is a box with double glass cover and in between the two covers there is air space. The covers are snuggly fitted in the top of the box. On inside bottom, there is metallic wax melting pan which slants to a container. The inside of the box is painted white while from the outside it is painted black. The melting tank/pan is fitted with a strainer at the outlet to strain off the sludge. The wax drips to the other container placed at the outlet of the melting pan. The solar wax extractor does not recover more than $50 \%$ of the wax but is convenient and cheap for rendering wax.

Use of wax. Beeswax is mainly consumed by candle industry and bee industry for preparing comb foundation sheets. Wax is also an important constituent of cosmetics like cold creams, lipsticks and rouges because it adheres better to skin. Pharmaceutical and perfume industries are also major users of wax. It is also used in ointments, capsules, pill coatings and deodorants. Wax is used for preparing shoe polish, furniture, etc. because it acts as water proofing. Its minor use is made in adhesives, chewing gums and inks etc.

\section{Bee venom}

Sting of worker bee is attached to a poison sac where venom is stored. Newly emerged bee is unable to sting because she cannot insert the sting which is not fully chitinized. Moreover, the re is very little venom stored in the venom sac. A bee, when two weeks old has maximum venom in her poison sac and there is no more addition to this quantity. Composition of bee venom is complex and is composed of many active substances such as histamine, apamine, acithinase, hydrochloric acid, formic acid, orthophosphoric acid, sulphur, calcium, copper and magnesium sulphate.

Production. Commercial method of obtaining bee venom is by the use of electric shock (Fig.76). Thin copper wires are stretched about one centimetre apart on a wooden frame which is alternatively charged. This wired frame is inserted between the bottom board and the brood chamber. An electric current is passed through the wires at 12 volts. The bees get shock when come in contact with any two conducting wires. Such bees get irritated and release venom by inserting the sting into a thin nylon cloth below the copper wires. Venom is deposited on a glass plate placed below the nylon sheet. The 


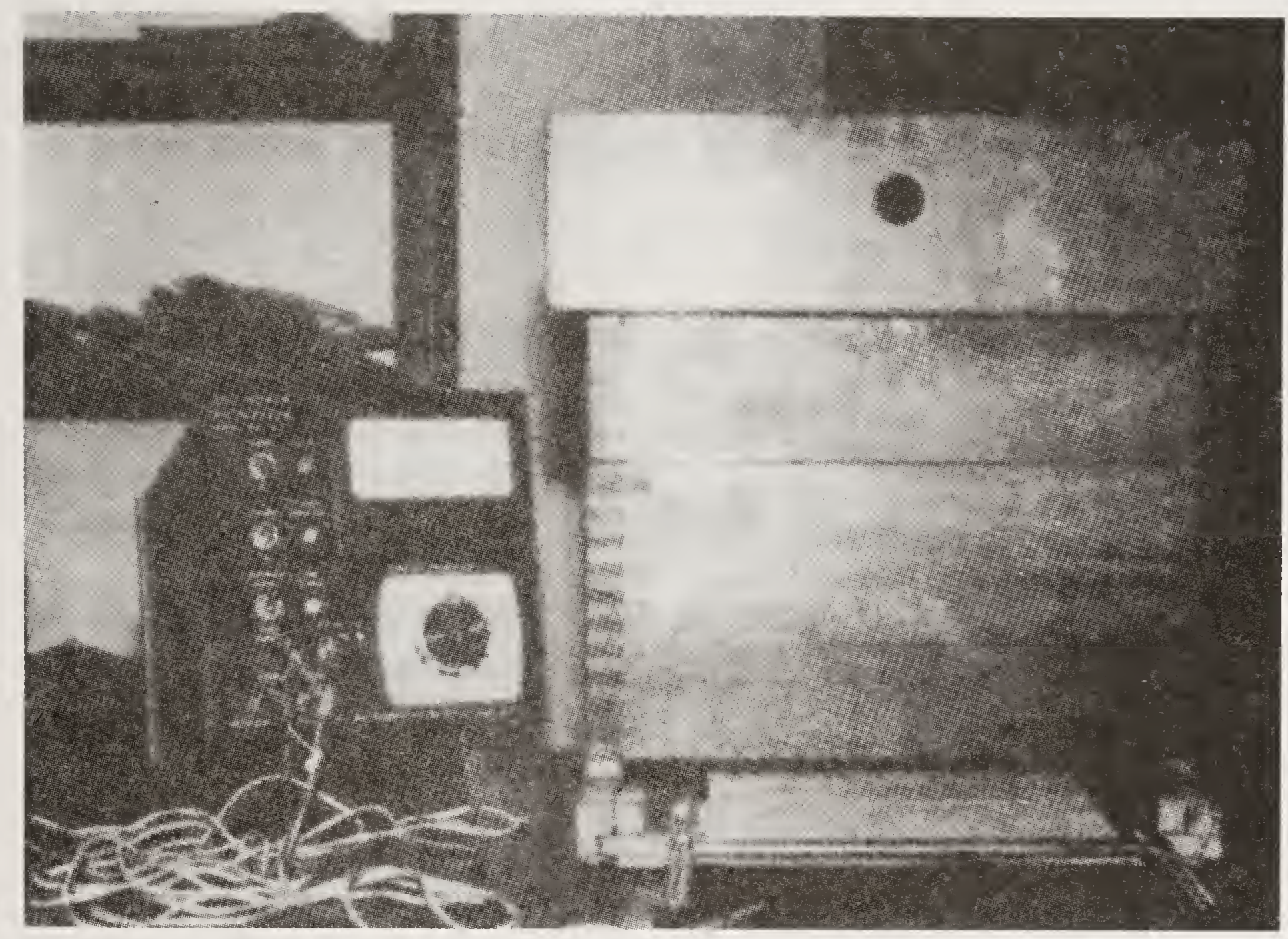

Fig. 76. Bee venom production unit. A wooden frame with fine copper wires is inserted above the bottom board. An electric currrent at controlled voltage is passed through the wires.

venom on drying is scrapped from the glass plate. One mellifera colony yields about $50 \mathrm{mg}$ of venom. Bees which release the venom do survive but the colony gets greatly irritated. It takes about $5 \mathrm{~min}$ to milk a colony.

Another crude method is to place bees in wide mouth glass jar which is then covered with filter paper. Some ether is poured on the filter paper, the vapours of which irritate bees and they deposit venom on the walls of glass jar.

Apitherapy. Bees can be made to sting the patient by holding the bee from her wings with thumb and index finger or by tweezers. Number of stings at a time can be increased from one to three, over a period of 2-3 weeks. The venom collected by above methods can be made for sub-cutaneous injections. Ointment made by mixing apitoxin, vasaline and salicylic acid (1:10:1) can be applied on the affected areas. The salicylic acid makes the skin soft and increases penetration.

Bees venom has been reported to be useful for curing many diseases and disorders. Rheumatism cannot be cured by any other system of medicine but majority of patients can be cured by bee venom. It has stimulating effect on heart muscles and decreases cholesterol level and also lowers blood pressure. Bee venom has also given positive results in curing neurosis, endoarteriosis, endoarthritis and neuraglia.

Some people may show allergic reactions to bee venom and bee sting causes general indisposition, vomiting and diarrhoea but with time many become immune. Protein antigens of bee cause hypersensitivity. Antihistamine 
creams or injections and adrenaline are used as anti-allergents. Honey and ethyl alcohol plus ascorbic acid $(100 \mathrm{~g}+200 \mathrm{ml}+1 \mathrm{~g})$ in one litre of water is given to allergic person after every $2-3 \mathrm{hr}$ and this mixture is good antiallergent. These are only first aid measures, however, doctar should be consulted.

\section{Propolis}

Propolis is gathered by bees from resinous exudes of trees. In the bee colony propolis is used by bees for sticking frames, sealing cracks and crevices but it makes handling of frames difficult and is also a contaminant of comb wax. Propolis is mainly composed of resins and balsams 55\%, ethanol and scented oils $10 \%$, and pollen 5\%. Many flavonic components have also been identified.

Propolis is obtained by scrapping it from the frames. It has quality of healing wounds effectively and common use in preparing ointments for treating cuts; wounds and abscesses in cattle. Mixed with vasaline, it soothens burns.

\section{Royal jelly}

Royal jelly is secreted by glands of nurse bees of the age of 6-12 days when the glands are fully active. It is very nutritious food and is fed to the young worker larvae and the queen larva and adult. Royal jeely is milky or light pale in colour. It is composed of proteins $15-18 \%$, lipids $2-6 \%$, carbohydrates $9-18 \%$ and ash $0.7-1.2 \%$. It contains $65-70 \%$ moisture. The proteins are mainly amino acids which are alanine, arginine, aspartic acid, gultonic acid, glycine, isoleucine, lysine, methionine, phenyl alanine,
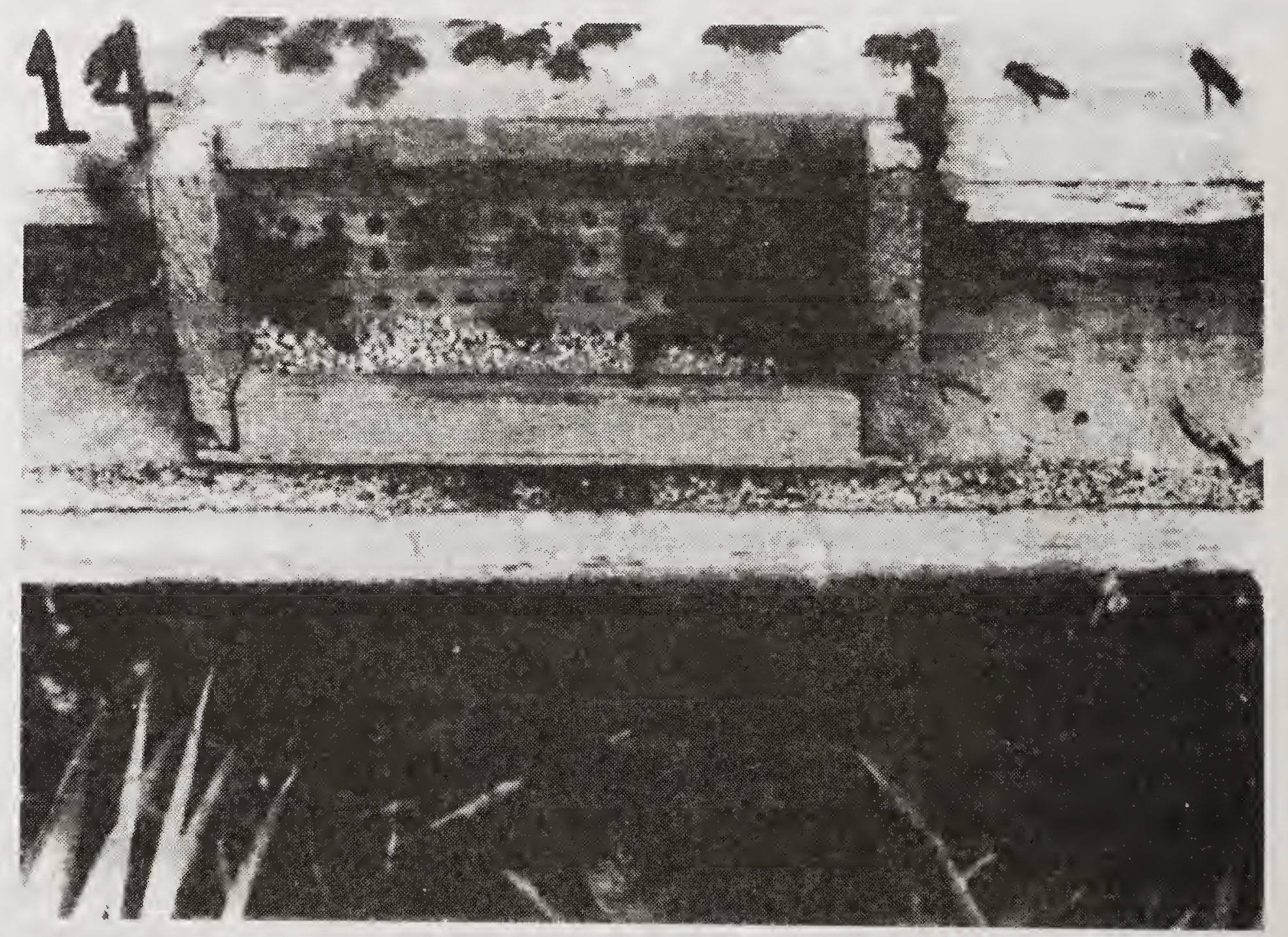

Fig. 77. Pollen collected in a pollen trap during Brassica flowering. 
tryptophane, tyrosine and serine. Eight essential amino acids for human beings, aré present in royal jelly. Carbohydrates in royal jelly are glucose, fructose, melibiose, trehalose, maltose and sucrose. It also contains vitamin $\mathrm{A}, \mathrm{B}$ and $\mathrm{C}$. Iron, copper, phosphorus, silicon and sulphur are also present in royal jelly. Royal jelly contains some other chemical constituents which are responsible for queen determination and full knowledge of the chemical composition is lacking.

Royal jelly is very nutritious food for human beings as it increases vigour and vitality. It can be taken alone or in mixture with honey. It is not commercially produced in India. Royal jelly production efficiency of Indian bees is not studied but in case of Apis mellifera about $200 \mathrm{mg}$ of royal jelly is obtained from a queen cell. For royal jelly production the technique used for mass queen rearing by Doolittle method (explained in Chapter 7) is practicable. The queen cell is trimmed to the level of the royal jelly and after two or three days of grafting, larvae is gently removed with forceps and the royal jelly is removed with royal jelly spoon. This is stored in refrigerated conditions.

Pollen (Fig.77) collected by pollen trap from ingoing pollen foragers is a rich protein source for human diet.

\section{REFERENCES}

I.S.I. 1969. Specifications for honey. Indian Standard No. IS:4941-1968: 18.

Kalimi, M.Y. and Sohonie, K. 1965. Mahabaleshwar honey. III. Vitamin contents (ascorbic acid, thiamine, riboflovin and niacin) and effect of storage on these vitamins. J. Nutr. Dietet. 2(1) : $9-11$.

Nair, K.S. 1980. Physico-chemical characteristics of rubber honey in India. Proc. 2nd. Int. Conf. Apic. Trop. Climates, New Delhi, 1980 : 676-84.

Phadke, R.P: 1962. Physico-chemical composition of major unifloral honeys from Mahabaleshwar (Western Ghats). Indian Bee J. 24(7/9) : 56-65.

Phadke, R.P. 1967. Studies on Indian honeys.1. Approximate composition and physico-chemical characteristics of Indian multifloral apiary honeys from Apis indica bees. Indian Bee J. 29 : $14-26$.

Phadke, R.P., Nair, K.S. and Namdekar, K.U.1970. Studies of Indian honeys. IV. Minor constituents. Indian Bee J. 32(1/2) : 28-35.

Phadke, R.P., Nair, K.S. and Namdekar, K.U. 1971. Indian bee waxes.II. The nature of their chemical constitutents. Indian Bee J. 33(1/2) : 3-5.

Phadke, R.P. and Phadke, R.S. 1975. Physico-chemical characteristics of waxes from Indian honey bees.II. Viscosity and refrective index. Indian Bee J. 37(1/4) : 15-18. 


\section{POLLINATION}

All living animals and plants reproduce for the continuation and increase of their species. Plants reproduce asexually or sexually. The formation of offsprings without involving the union of sperm and egg cell such as in rhizomes, tubers, grafts, stolons, etc. is asexual reproduction and is commonly referred as vegetative reproduction. There is fertilization of egg in the ovary with sperm cells from pollens in flowering plants for producing seed from which daughter plants are raised in sexually reproduced plants. Sexually reproduced plants are flower bearing. The flower is a part of plant which contains pollen for the production of sperm cells and embryo sacs for the production of egg cells. The flowers may be perfect that have both male and female parts in the same flower or imperfect that produce only pollen or embryo sacs. In some cases the flowers may appear to be perfect but have one sterile sex. Imperfect flowers can be present on the same plant (monoecious plants) or one plant may have only pollen or only embryo sacs (dioecious plants) that is, imperfect flowers of two sexes are borne on separate plants.

\section{Pollination and fertilization}

For sexual reproduction the prerequisite is transfer of pollen from the male part (anther) to the respective stigma of the female part (pistil). Various terms are used to describe different situation of pollination:

1. Self-pollination. Transfer of pollen from anther to stigma of the same plant or to another plant with similar genetic make up. Two plants from a single clone or plants of a completely 'homozygous' variety have identical genetic formation. A completely homozygous plant is one whose sex cells have indentical sets of parental chromosomes. When they undergo meiosis, the daughter nuclei are indentical and in such plants, the offsprings are genetically similar if self-pollination takes place.

(a) Auto-self-pollination. It is self-pollination where no external agent is involved in the transfer of pollen. This is usually brought about by growth and movement of flower parts. Auto-self-pollination can occur within the same flower (autogamy) or between adjacent flowers (allogamy) on the same plant (geitonogamy) or on different plants (xenogamy).

(b) Indirect self-pollination. Self-pollination effeted by some external agent is called indirect self-pollination. This type of pollination may again be autogamy or allogamy.

Inheritable characteristics of both the parents through egg and sperm cells are combined in the developing embryo. No new genetic elements are incorporated in the offspring if the parents are the same. But due to independent segregation during reduction division, there can be recombination in different 
patterns and the resulting offsprings from self fertilization may differ from their parents.

2. Cross-pollination. Cross-pollination is the transfer of pollen from the anther of one plant to the stigma of another plant with different genetic make up. Cross pollination is always brought about by some external agents. The pollen transfer can be between two plants of a single variety (intra-varietal cross pollination); between two varieties differing widely in genetic make up (inter-varietal cross pollination) or between separate species or genera (Interspecific or intergeneric cross pollination).

Pollen, when transferred to stigma, germinates and grows as a pollen tube through the style to the embryo sac. It discharges two sperm nuclei in the embryo sac; one unites with egg cell and accomplishes fertilization and the other unites with the polar bodies to form the endospern nucleus. From the latter develops the seed endosperm and it dies out early in the development of young seedling.

Fertilization is also generally essential for the development of the fruits around the seeds, though parthenocarpic development does take place in some instances where ovary enlarges in a fruit without stimulation. Developing seeds in the ovary are understood to provide stimulus for fruit development in adjacent area. Inadequate pollination in plants with more than one ovule results in lopsided development of fruits.

Cross pollination on the other hand can lead to complete pollination and fertilization. It also induces hybrid vigour where the plants are more vigorous than the parents in terms of size, quality, maturity, susceptibility to diseases, etc. Cross pollination increases the range of variations in the population and unfavourable recessive hereditary features remain ineffective. The plants propagated asexually can survive for a long time but continuous asexual reproduction results in fixed genetic structure. Such plants are incapable of adjusting to changes. Many species which are self pollinated will perish if occasional cross pollination does not take place. On the other hand some plant species are completely dependent on cross pollination for reproduction.

There are many mechanisms in plants which favour cross pollination and cross fertilization. Imperfect flowers, dioecious plants and dichogamy where anthers mature before stigma (protandry) or stigma matures before anthers (protogyny) are the conditions which favour cross pollination. Placement of reproductive parts is sometimes against self pollination. In some crop varieties the pollen of same variety is incapable of fertilizing the ovary and pollen from other pollinizer variety should be transferred. Another condition may exist, where foreign pollen grows faster as a pollen tube and fertilizes the egg and favours cross fertilization. In perfect and cleistogamous flowers the self pollination is favoured. In self-pollinated plants the anthers and stigma mature at the same time. In these plants the male and female parts readily come in contact and selfing is effected.

\section{External agents of pollen transfer}

There are many agents which transfer pollen and bring about pollination. 
Though our main concern is insect pollination and their management for pollination, yet the relative value of these agents should be recognized.

Abiotic agents. Wind is the most important pollinating agent for man's well being. All millets, maize, barley, wheat and rice which constitute about two-thirds of the cropped area in India are wind pollinated crops. Many other important crops like sugarcane, walnut, coconut, palm, coffee, date palm, potato, tomato, etc, are also wind-pollinated crops. These anemophilous plants have small inconspicuous flowers which produce abundant dry and light weight pollens. The flowers are unattractive to insects with anthers exposed to wind for the pollen to be wind-borne and stigma is feathery so that large surface can facilitate wind-borne pollen transfer to it.

Water pollination (hydrophily) is only limited to few plant species. Water currents carry pollen from one plant to another and pollination takes place in water. Rain drops also transfer pollen and is an important agent in pollination of black pepper and other plants of the family. Pollen from upper flowers also drop off under gravity and incidently fall on the stigma of lower flowers and effect pollination; this type of pollen transfer is aided by dislodging of pollen by insects.

Biotic agents. Many categories of animals are involved in pollen transfer and in helping pollination. Bats and birds contribute in pollination mostly in tropics. Some specialized groups of these feed on nectar and pollen of colourful, large flowers which produce abundant nectar. They are common visitors of wild flowers. Man is always interested in the optimum pollination of economic plants and he sometimes hand pollinates crops. He is also keen for the improvement of the crops and uses hand pollination in his breeding work.

Insects are most important group of pollinating agents. Insect pollinated flowers are characterized by their conspicuousness, distinct odour and presence of nectar with sticky large pollen.

Much is not known about the co-evolution of bees and flowering plants. The fossil records are scanty but we can draw some inferences from our present knowledge of existing relationships. Angiosperms were predominantly present about 100 million years ago. The first premitive insect appeared 300 million years ago (Carboniferous age), i.e., much before angiosperms came into existence. Hymenoptera were present about 80 million years before the angiospermous explosion. Bees evolved from sphecoid wasps during the Cretaceous period and continued through the Tertiary and Quaternary periods which matched by corresponding emergence of flowering plants with various flower shapes. Plants compete for pollinators. To avoid this competition, flowering periods of some plants have been shifted. Some plants flower before vegetative buds open, others when leaves are there and still others flower late in the season. Flowers have become conspicuous by colour contrasts. Plants have also evolved to present no rewards to pollinators but yet get pollinated by insects and this happens by mimicry, scent or even appeal like mating apparatus for pseudocopulation. On the other hand insects compete for nectar and pollen and they develop foraging strategies for efficient harvest of rewards. 
Insect pollinators. There are varied groups of flower visiting insects. They mainly belong to the orders Coleoptera, Diptera, Lepidoptera and Hymenoptera. All these flower visitors are not equally important pollinators of crops. It is necessary to consider the following qualifications to assess their relative effectiveness.

1. Foraging behaviour. The insect should show flower fidelity and the pollinator must restrict to the flowers of one plant species to effectively pollinate the crop. The insects which flit from flowers of one crop to those of another will cause little pollination. Foraging behaviour is another important attribute. The forager should have thoroughness in working and should come in contact with male and female parts. It must work in all weather that permit pollen release. The flower visitors should start their work early in the day and continue late in the evening so that they have longer working hours. The efficient insect pollinator would carry large quantities of viable pollen on their bodies and restrict to flowers which have viable pollen and receptive stigma. Fast worker is ought to pollinate larger number of flowers.

2. Population. It would be highly desirable to have large population of pollinating insects at the blooming time of a crop. So large natural or manipulated population of insect pollinators make them more important pollen transferring agents.

Coleoptera. It is the largest order of insects and certain primitive flowering plants are beetle pollinated. Plants with small flowers and in groups are commonly visited by beetles. Flowers with concealed nectar, pollen flowers with abundant pollen, flowers with exposed nectar and smaller variety of flowers with partially concealed nectar are regularly visited by beetles. But any mutual adaptation between pollinators and flowers has not developed. Many beetles feed on petals as well as on pollen and nectar. Many flower visiting beetles are small in size and can enter the narrowest corolla. Beetles are poorly adapted as pollinators. Flower foraging beetles have short tongue and maxillae covered with hairs which facilitates sweeping of pollen. The group has poorly developed sense organs and cannot distinguish between different flowers. They may take one meal from a single flower or from many different flowers and thus are unreliable pollinators.

Diptera. Flies have sucking and lapping type of mouth-parts. Parasitic and house flies are common flower visitors. A few families live exclusively on nectar and pollen. Flies are commonly found on pollen flowers (poppy, rose, potato), flowers with exposed nectar (Umbeliferae, grapes), flowers with partially concealed nectar (stonefruits, strawberry, crucifers and cacti) and flowers with concealed nectar (orange, onion). Adults of almost all hover flies (Syrphidae) feed on nectar and pollen. Their sense of smell and colour are better developed than in other flies. They prefer yellow to other colours and they also show flower constancy. Flies normally bring about pollination in flowers that they visit but the flower-pollinator relationship is not well developed. Diptera are important pollinators in arctic regions where more specialized hymenopteran pollinators are absent.

Lepidoptera. Adults of some butterflies and moths live without food and 
few primitive moths feed on pollen. Most adult Lepidoptera have long-coiled sucking proboscis and suck nectar from Lepidopteroid flowers which have long corolla tubes (honeysuckle, tobacco, phlox, and orchids). While sucking nectar, pollen sticks to proboscis and body and is transferred to stigma of their flowers. Hawk moths are more reliable pollinators of the order.

Hymenoptera. This insect order has very varied types of plant pollinators. Parasitic hymenopterans (Apocrita) appear as general visitors. Because of their small size and slender bodies they can obtain nectar from hidden nectaries. The stinging group (Aculeata) includes important pollinators such as ants, wasps, hornets and bees. The plants which are low, often sprawling, growing in poorly vegetated places with small non-showy flowers with little but accessible nectar, are ant pollinated. The flower visiting ants walk on foot and generally do not come in contact with anthers and stigma and at the most can accomplish self pollination. Vespoid wasps (hornets, scoliid wasps) have large hairy bodies and are well adapted for pollination. Some of these can trip alfalfa. Adults of spider wasps (Pompilidae) and digger wasps (Sphecidae) feed on nectar or both nectar and pollen. Sphecids are the most abundant visitors of carrot, cotton, sweet clover, sunflower etc. By far the most important group of hymenopterous pollinators is Apoidea. In some cases the females lay eggs on the stored pollen. Adults of all species feed on nectar and pollen. They have their characteristic nesting places. Bees have collecting apparatus and have a degree of flower constancy. They may be obligotropic. Only few species of wild bees can be managed to some degree and manipulation of their population for pollination is limited. But honeybees, Apis spp. have many desirable qualities and surpass all other insects in their value as pollinators.

The advancements in agricultural technologies have resulted into dwindling of wild insect pollinators. Extensive agriculture has resulted into clearing of wasteland. Mechanized agriculture leaves very little corners and field bunds. These have caused reduction in hibernating and nesting sites for wild pollinators. Crops used in primitive agriculture followed the flowering pattern of indigenous plants in the area with the correspondence between pollinating requirement and number of pollinating insects. This correspondence has been disturbed due to crops introduced into the ecosystems. Trends for monoculture provide plenty of food to insect pollinators for a short duration but not even subsistence food for most of the remaining period and this is to the detriment of well being of pollinators. Weed control in the present agriculture destroys certain food sources of insect pollinators and seriously affects their population. Wild pollinators and honeybees are also killed by pesticidal use in crop protection. Because of these facts dependance on hive bees for pollination of crops is on the increase.

\section{True honeybees (Apis spp.)}

Apis spp. are the most valuable pollinators of commercial crops. The bee population can be increased and colonies can be managed to achieve the optimum pollination. Honeybees possess some qualities which are in common 
with other bees. They have bodies covered with branched hairs. Both adults and immature stages depend on nectar and pollen for food and they are not injurious to plants with no public health menace. True honeybees store nectar and pollen for colony requirement and, therefore, are superior pollinators as compared to wild bees and other insect species which forage only for their own requirement. Honeybees also need to be active in winter and this makes them to visit more flowers than the species which hibernate during winter. Honeybees can warm up and are capable of foraging at lower temperature. The body size and proboscis length of honeybees suits them to forage many varied types of flowers than other insect pollinators. The host range of bees is very wide and thus can serve as pollinator of many types of crops. Honeybees are highly evolved social insects. Their foraging behaviour patterns are highly favourable to qualify them as the most efficient pollinators of crops.

Foraging behaviour of honeybees. Honeybees have highly organized field activities. Knowledge of the behaviour pattern. can help the beekeepers to exploit bees for better pollination services and honey production.

Bee fly in the vicinity of the hive in search of food sources and these are the worker bees which have completed their phase of hive duties. This scouting is irrespective of communication by foragers. After discovering a source the workers gather a good load of nectar and/or pollen, return to the hive and communicate the information to field bees in the hive. The field bees then decide upon the suitablity of alternate sources searched out by the scout bees.

Activites of field bees are greatly influenced by environmental factors. Foraging is reduced at lower temperatures and water foraging increases above $34^{\circ} \mathrm{C}$. Rainfall also adversely affects foraging activities. Bees avoid going foraging when the wind is high. Depending upon the availability and access, the bee foragers collect nectar or pollen. Nectar gatherers are not always exclusive but may also collect pollen along with nectar. The nectar gatherers, though spend more time foraging on a flower but they may reach the nectaries by side working and may not come in contact with reproductive parts of the flowers. Even top workers can specialize to collect nectar through the reproductive column without effecting pollination. Nectar gatherers, in general, carry less pollen grains on their bodies and are poor pollinators. Pollen gatherers work on the flowers more thoroughly and are established to be the better pollinators. Even pollen collectors take some nectar and many a times there is overlapping of rewards collection. The proportions of these reward collectors is believed to depend upon the needs of the colony, though availability of rewards is important.

Communication and memory. Bees on the combs perceive the odour of floral rewards brought in by fellow foragers or scouts. Coupled with odour perception they also communicate the direction and distance of source by performing signal dances. Because of this efficient communication the bees scatter on all potential sources within a radius of $2-3 \mathrm{~km}$. They keep on changing to new sources with changes in availability and preferences. The information is rapidly spread in the hive. The richer sources are informed 
through more lively and vigorous dance and by more number of returning individuals. As a result better sources have more abundant bees than poor and distant sources. This competition is an important aspect of successful pollination.

Bees have memory and they continue to visit the source as long as they don't find a better one. They also restrict their successive visits to a restricted area. This behaviour varies with crop and cultivars of crop. The knowledge of this behaviour is essential for hybrid seed production. Nectar and pollen rewards are available during particular hours of the day and bees memorize to visit the source during those hours. They shift to other sources during other times of the day. Breeding bees with preferences for specific crop has been possible in case of alfalfa.

Flight range and foraging rate. Honeybees can have extreme foraging range up to $7-10 \mathrm{~km}$ but economic foraging range is up to $2 \mathrm{~km}$ for Apis mellifer $a$ and $1 \mathrm{~km}$ for Apis cerana indica. Within these ranges the richness of source is more important than distance from the hive but young foragers forage close to the hive. Energy balances in nectar collection are more favourable with decrease in distance. Nearer sources are easily located by bees and more visits are made by them resulting in better pollination of the crop. Benefit is further achieved in pollination by more number of trips made by each forager per day.

Number of flowers visited per unit time depends upon the abundance of pollen and nectar per flower. The foraging rate is also affected by environmental condition, that is, at lower temperatures bees may need time to raise their thoracic temperature in between the time spent to collect nectar or pollen from each or few flowers. To collect a load, a bee may visit few (25) to many (400) flowers. Bees often return to the hive without a full load when the source is poor. Nectar collecting bees may have incidental pollen collection in which case too the load is not full.

\section{Pollination of crops}

Pollination requirements vary with the crop species. Enough information has been gathered on this aspect on crops in temperate regions but sufficient knowledge of pollination ecology and pollination requirements of crops in tropical and sub-tropical regions is lacking. More than 50\% of existing species of plants propagated by seeds are dependant upon insects for adequate pollination. Though, some interest has been evoked in the field of crop pollination for increasing the crop yields in India, potentials of planned pollination of crops are not fully exploited. The fact that beekeeping and agricultural productivity are closely interlinked, has not been fully realized and appreciated. Very brief account is given in this chapter on the pollination requirement of crops in India. General statements are given on the basis of work done in other countries and specific work carried out in India is cited under different crops.

Fruits and nuts. Most commerical cultivars of apple (Malus spp.) are self-incompatible and inter-plantings of pollinizẹr cultivars is required. Inserts 
mediate cross-pollination in apple. Mishra et al. (1976) observed honeybees, Eristalis, Syrphid flies, Heliothis and Plusia moths visiting apple bloom. Flower visiting flies outnumber Apis cerana indica on blossoms of pome and stone fruits (Singh and Mishra, 1986). Pollinating insects greatly increased fruit set in apple (Sharma, 1961). Bees tend to forage near hive and the trees more than 300-400 $\mathrm{m}$ away are seldom visited. The fruit set is increased with decreasing distance from the hive (Mishra et al., 1976).

Generally 2 bee colonies per hectare are recommended but 'Delicious' cultivars favour side working by bees and thus require more than 2 colonies per hectare. Pear. (Pyrus spp.) is similar to apple in pollination requirement. Nectar sugar concentration in pear is low (8-10\%) and is not a good bee plant but higher fruit set is obtained by bee pollination than under selfing. Sometimes parthenocarpic fruits are formed but they are of poor quality. Most varieties of peach (Prunus persica (L.) Batsch are self-fruitful but 'J.H. Hale', 'June Elberta' and 'Giant' are self-sterile. Peach flowers are visited by Apis spp., flies and bumble bees (Bhalla et al., 1983; Man and Singh, 1981) and fruitset is higher in unbagged than in bagged flowers (Mann and Singh, 1981), but Kumar et al. (1984) assessed the pollination requirement of 14 common cultivars of peach in Himachal Pradesh and found that these do not require insect pollination, since fruit set was equally good under caged conditions where insect and wind pollination was not allowed. Plums (Prunus spp.) are mostly self-compatible but honeybees are the main flower visitors of plum (Bhalla et al., 1983; Mann and Singh, 1983) and greatly contribute in fruit set (Mann and Singh, 1983). Apricot vary in pollination requirement. Bee pollination has been proved to be beneficial for increased fruit set and yield in some cultivars and 2-3 colonies per hactare, evenly distributed, are recommended for optimum pollination. In cherries self-pollination does not occur but some cultivars are self-compatible.

Litchi (Litchi chinensis Sonn) is grown for its fruits in tropics at elevations up to 900 M.A.S.L. in the foot hill areas. Nectar of litchi flower is highly attractive to bees and other insects. The flower panicles have only male flowers for first few days, male and female flowers for next few days and only male flowers again for the last few days. Wind pollination does occur but fruit set is higher by insect pollination and little or no fruit set is obtained under selfing (Pandey and Yadava, 1970). Honeybees and stingless bees comprised $98-99 \%$ of the flower visitors. Citrus species and varieties greatly vary in their pollination needs. There can be parthenocarpic fruit development or selfing may give good fruit crop but in some there is self sterility. Sweet lime (Citrus limettoides Tanaka) needs bees for pollination (Nijjar and Sandhu, 1971). Mandarin oranges are generally benefited from cross-pollination. Citrus has also not been fully worked out for pollination requirements.

Jujube (Zizyphus mauritiana Lamk.) flowers are visited by many insects. Polistes wasps as well as honeybees are the main visitors (Dhaliwal, 1975). Vitis spp. (grapes) sets fruit by self or wind-pollination. Mann and Tanda (1984) reported that Apis dorsata is the dominant visitor to this fruit crop. Besides this, the 2 species of syrphid flies also visited the blooms of this 
crop: Generally, no increase in fruit yield is obtained by insect visits. In papaya (Carica papaya L.) the plants have either male or female or hermaphrodite flowers. Bees collect pollen from male and hermaphrodite flowers. Best fruit set is obtained by cross-pollination. Pineapple (Ananas salivus) should be seedless for table fruit, but seed production is obtained by cross-pollination. Mango (Mangifera indica L.) bloom is visited mainly by dipteran insects. There are diverse views regarding bee visits but Apis florea is a common visitor and all the varieties are not attractive to bees. Benefits of bee pollination in fruit set and yield increase are not established.

Among the nut fruits, almond (Prunus amygdalus Batsch) is dependant on insects for fruit set. Many commercial cultivars are cross fruitful. Wild bees and honeybees are efficient pollinators. Moving bee colonies to almond orchard for pollination is a common practice in many countries. In India also almond cultivation is picking up. Almond flowers early in spring, when the weather is unsettled and also the bee colonies are not strong to provide enough force, therefore 5-7 colonies per hectare are recommended for pollination. In cashew (Anacardium occidentale L.) poor setting is a problem. No fruit set is obtained by selfing and cross-pollination is apparently by insects. Honeybees collect nectar and pollen, though exact information is lacking yet bee colonies in plantations should help in increasing fruit set.

Vegetable crops. Flowers of many vegetable crops are good forage for bees. But vegetables meant for table purposes are not allowed to flower because it is not the fruit which is eaten in many vegetables. But in almost all the cases the propagation is by seed and insect pollination is important in seed production. Cole crops (Brassica oleracea L.) are cross-pollinated to the extent of $95 \%$. The bloom is visited by wild bees and flies but honeybees are the most credited pollinators. Lagre number of insects visit cauliflower bloom for nectar and pollen (Sharma et al., 1974; Kakar, 1980). The insect visits produce more number of seeds per pod and weight of seed is greater as compared to selfed plants (Sihag, 1986; Kumar et al., 1988). Pod setting, number of seeds per pod and seed weight were increased by bee pollination (Verma and Joshi, 1983; Tewari and Singh, 1983). Existence of protandry in the flowers of Umbelliferae crops necessitates cross-pollination. Flowers of coriander (Coriandrum sativum L.), carrot (Dacus carota L.) and fennel (Foeniculum vulgare Mill.) are visited by many insects (Naryanan and Sharma, 1960; Sagar, 1981). Sagar (1981) also found that weight of seed produced by 1,000 umbels was $31.2 \mathrm{~g}$ on plants visited by insects but only $15.6 \mathrm{~g}$ on plants caged to exclude them. The observations on the benefit of insect visits to umbelliferous crops have been confirmed by Sihag (1985).

Egg plant Solanum melongena L., tomatoes (Lycopersicon esculentum Mill) and pepper (Capsicum spp.) probably do not need insect pollination. The flowers of these crops, though visited by some insects but honeybees are rare. Okra (Hibiscus esculentus L.) is a self-pollinated crop but is visited by bees and other insects (Chaudhary et al., 1973; Mishra et al., 1987) and there is 5-20\% cross-pollination. Modes of,pollination did not affect seed weight, per cent dry matter, protein and alcohol soluble sugar contents but weight 
and length of capsules of okra and seed number were found to be significantly higher in open pollinated than in bagged flowers (Mishra et al., 1987). Allium cepa L. is the common species of onion in India. In seed crop cross pollination is common and self-pollination cannot occur because of protandry and sticky pollen. Variety of insects visit onion flowers both for nectar and pollen but honeybees are most important. Great benefits of insects or bee pollination over selfing have been established (Singh and Dharwal, 1970; Rao and Lazer 1980; Jadhav, 1981; Jadhav and Ajri, 1981; Kumar et al., 1985) but ro specific recommendations are available.

In cucurbits the male and female flowers are separate on the same plant. The pollen grains are heavy and large sized. Grewal and Sidhu (1978) found that bees (Xylocopa, Bombus, Pithitis and Nomioides) and wasps are primary pollinators but in some cases like in Cucumis melo L. and $C$. sativus $\mathrm{L}$. the bee pollination is also considered important (Grewal and Sidhu, 1983).

Pulses. There is hardly any information on the pollination needs of pulses. Most pulse crops are considered to be self-pollinated but bees do visit the flowers of many pulse crops and benefit of bee pollination in increasing yield, have also been demonstrated in isolated cases. There is need to work on the pollination requirements of these crops and to accumulate a good body of knowledge so that optimum pollination is not the constraint in increasing productivity.

Oil crops. Mustards, rapeseed and related Brassica species are extensively grown for oil production in India. In Brassica juncea (L.) and Sinapis alba L. the stigma of the flower projects from the bud before opening and it is receptive. Wind is an important cross-pollination agent but of primary importance are insects and benefits of bee pollination have been reported for increasing crop yeilds (Sihag, 1986). B. campestris L. is largely dependant on insects for pollination. Many insect visitors are present on profuse bloom of the crop but principal among them are honeybees. This is an excellent source of nectar and pollen. Values for yield parameters such as pod set, number of seeds per pod and weight of seeds were higher in insect/beepollinated than wind or self-pollinated crop (Bisht et al., 1980; Mishra et. al., 1988).

Niger (Guizotia abyssinica (L.f.) Cass is a good bee plant and is becoming more and more popular in India. There is $20-75 \%$ cross-pollination in this crop. Only information available on its pollination is by Bhambure (1958). His experiments, using screen cages, showed that 40 seeds per head were produced in plants caged with bees but only 15 seeds per head were set when the plants were caged without bees. Sunflower (Helianthus annuus L.) provides high quality nectar and pollen and bee pollination gives more yield. Moving bee colonies to sunflower fields increases seed setting by 27\% (Panchabhavi et al., 1976; Basavanna, 1979). Wakhle et al. (1978) also reported increase in oil contents by bee pollination in sunflower. Safflower (Carthamus tinctorious L.) is a good source of nectar and pollen. It yields more when pollinated by bees. Cross pollination in different cultivars vary from 5-80\%. Coconut (Cocos nucifera L.) offers both nectar and pollen to bees. Wind 
pollination is important but evidence is accumulating that coconut production can be improved by augmenting pollination by bees. The value of bees for pollination in this crop is not properly demostrated.

Forage crops. Insects are important for pollination of berseem (Trifolium alexandrinum L.) and wind is ineffective. Tripping efficiency of insect visitors is in the order of Apis florea, Megachile flavipes, Pithitis smaragdula, Apis mellifera and $A$. dorsata (Dhaliwal and Atwal, 1976). Berseem is an important surplus honey: source in north western plains. Alfalfa (Medicago sativa L.) is grown in drier parts of tropical India. It requires insects for pollination and wild bees have been found to be more effective (Kapil et: al., 1970). Honeybees are also associated in pollination of the crop.

Fibre crops. Cotton (Gossypium spp.) is the most widely grown fibre crop in India. While studying the role of agents of cross-pollination in cotton, Sidhu and Singh (1961) obtained no boll setting in emasculated flowers and those protected from insects. Insect pollinators have been recorded and plants caged with $A$. cerana indica and $A$. florea gave $17 \%$ more cotton seed than in plants without insects (Sidhu and Singh, 1962). Bolls per plant, weight per boll of seed and cotton lint and seeds also increased. But lint index, length and weight on maturity of cotton fibre were not affected. Similar results were reported on Asiatic cotton by Tanda : and Goyal (1978, 1979a, 1979b). Honeybees are ineffective in bringing about pollination in sunhemp (Crotalaria juncea) because they robbed flower nectar through a hole cut in the lateral portion of keel but wild bees were important pollinators (Jitendra Mohan, 1973).

\section{REFERENCES}

Basavanna, G.P.C. 1979. Role of insect pollinators in sunflower production. Curr. Sci. $8(1) \div 1-3$. Bhalla, O.P., Verma, A.K. and Dhaliwal, H.S. 1983. Foraging activity of insect pollinators visiting stone fruits. J ent. Res. 7(2): 91-94.

Bhambure, C.S. 1958. Effect of honeybee activity on niger seed productions Indian Bee J.20(12): 189-91:

Bisht, D.S., Nain, M. and Mehrotra, K.N. 1980. Studies on the role of honcybees in rapesced production. Proc. 2nd Int. Conf. Apic. Trop. Climates, New Delhi, 1980 : 491-96.

Chaudhary, B., Choonsai, M.L.A. and Menon M.G.R. 1973. Insect pollination in some vegetable crops. Haryana J. hort. Sci 2(1/2): 56-62.

Dhaliwal, J.S. 1975. Insect pollination in ber (Zizyphus mauritiana Lank.) Curr: Sci: 44(14) $: 527$.

Dhliwal, J.S. and Atwal, A.S. 1976. Note on the effect of air temperature, relative humidity and wind velcocity on bees visiting berseem (Trifoliumalexandrinum L.) at Ludhiana Indian J agric. Sci. 46 (1) : 50-51.

Grewal, G.S. and Sidhu, A.S. 1978. Insect pollinators of some cücurbits in Punjab. Indian J agric. Sci. 48(2): 7.9-83.

Grewal, G.S. and Sidhu, A.S. 1980. Studies on insect pollination in Cucumis melo Linn. Proc. 2 nd Int. Conf. Apic: Trop. Climales, New Delhi, $1980: 537-44$.

Jadhav, L.D. 1981. Role of insects in the pollination of onion (Allium cepa) in the Maharashtra state, India. Indian Bee J. 43(3) : 61-63.

Jadhav, L.D. and Ajri, D.S. 1981. Insect pollinators of onion (Allium cepa), in Ahmednagar district of Maharashtra, India. Indian Bee J. 43(4) : 109.

Jitendra Mohan, K.V. 1973̣. Some observations on the bee pollination in sunnhemp (Crotalaria juncea) and their importance in breeding work. Jute Bull. 35 :214-16. 
Kakkar, K.L.: 1980. Prospects of becs as potlinaüing agents of cauliflower: Proc.2nd Int. Conf. Apic. Trop. Climates, New Delhi, $1980: 445-56$.

Kapil, R.1P., Grewal, G.S., Kumar, S and Atwal, A.S.1970. Role of Ceratina bing hami Ckll. in seed selting of Medicago sativa L.. Seminar on forage production and itsutilization, Jhansi (India), 10pp.

Kumar, J., Mishra, R.C., Gupta, J.K. and Dogra, G:S. 1984: Pollination requirements of some peach culiivars:-Indian Bee J. $47: 3-6$.

Kumar, J., Mishra, R.C. and Gupta, J.K. 1985. The effect of mode of pollination on Allium species with observations on insects as pollinators. J. apic. Res. 24(1) : 62-66.

Kumar, J., Gupta, J.K., Mishra, R.C. and Dogra, G.S. 1988. Pollination studies in some cultivars of cauliflower (Brassica oleracea var. botrytis L.). Indian Bee J. 50(4) : 93-95.

Mann, G.S. and Singh, G. 1981. A note on activity and abundance of flower visiting. insects of peach (Prunus persica I.) at Ludhiana (Punjab). Prog. Hort. 13(3/4) : 25-27.

Mann, G.S. and Singh G. 1983. Activity and abundance of pollinators of plum at Ludhiana (Punjab). Am. Bee J. 123(8) : 595.

Mann, G.S. and Tanda, A.S. 1984. Aclivity and abundance of insects visiting grape flowers in Punjab (India). Proc. 3rd Int. Conf. Apic. Trop. Climates, Nairobi (1984) : 139.

Mishra, R.C., Dogra, G.S. and Gupta, P.R. 1976. Some observations on insect pollinators of apple. Indian Bee J. 38(1/9) : 22-22.

Mishra, R.C., Kumar, J. and Gupta, J.K. 1987. Effect of modes of pollination on fruit characteristics of okra, Abelmoscus esculentus (L.) Moench. Proc. Indian Natn. Sci. Acad. 53 B (2) : 157. 60.

Mishra, R.C., Kumar, J. and Gupta, J.K. 1988. Effect of modes of pollination on yield and oil potential of Brassica campestris var. sarson with observations on insect pollinators. J. apic. Res. 26(2):

Narayanan, E.S. and Sharma, P.L. 1960. Studies on requirements of various crops for insect pollinators. 1. Insect pollinators of Saunf (Foeniculum vulgare) with particular reference to the honeybees at Pusa, Bihar. Indian Bee J. 22(1/3): 7-11.

Nijjar, G.S. and S andhu, B.S. 1971. A study on the fruit set problem in sweet lime (Citrus limettioides Tanaka). J. Res. Ludhiana 8(4): 411-15.

Panchabhavi, K.S., Devaiah, M.A. and Basavanna, G.P.C. 1976. The effect of keeping Apis cerana indica F. colonics on the seed set of sunflower, Helianthus annus Linn. Mysore J. Sci. 10(4) :631-36.

Pandey, R.S. and Yadava, R.P.S. 1970). Pollination of litchi (Litchichinensis) by insects with special reference to honeybees. J. apic. Res. 9(2): 103-05.

Rao, G.M. and Lazar, M. 1980. Studies on the behaviour and pollination on Onion (Allium cepa L.). Proc. 22 nd Int. Conf. Apic. Trop. Climales, New Delhi, 1980 : 580-89.

Sagar, P. 1981. Role of insects in cross pollination of fennel crop at Ludhiana. J.Res. Ludhiana 18(4) : 388-92.

Sharma, P.L. 1961. The honeybee population among insects visiting temperate zone fruit flowers and their role in setting fruit. Bee wld 42(1) : 6-8.

Sharma, P.L., Dhaliwal, H.S. and Kakar, K.L. 1974. Insect visitors and pollinators of cauliflower (Brassica oleracea var. botrytis) seed crop bloom. Himachal J. agric. Res. 2(2) : 64-78.

Sidhu, A.S. and Singh, S. 1961. Studies on the agents of cross pollination in colton. Indian Cott. Gr. Rev. 15(6):341-53.

Sidhu, A.S. and Singh, S. 1962. Role of honeybees in cotton production. Indian Colt. Gr. Rev: 16(1) : 18-23.

Sihag, R.C. 1986. Insect pollination increases seed production in cruciferous and umbelliferous crops. J. apic. Res. 25(2): 121-26.

Singh, J.P. and Dharmwal, S.S. 1970. The role of honeybees in seed setting on onion at Pantnagar, District Nainital, U.P., India. Indian Bee J. 32(1/2) : 23-27.

Singh, R. and Mishra, R.C. 1986. Flower visiting flies of fruits in Himachal Pradesh, Proc. Indian naln. Sci. Acad. 52 B(4) : 451-53.

Tanda, A.S. and Goyal, N.P. 1978. Effect of bee pollination on boll retention in Gossypium arboreum Linn. Seeds and Farms 4(8) : 45-56.

Tanda, A.S. and Goyal, N.P. 1979a. Pollen dispersal by insects in desi cotton (Gossypium arboreum Linn.). Seeds and Farms 5 : 56-59.

Tanda, A.S. and Goyal, N.P. 1979b. Some observations on the behaviour of Apis mellifera Linn. and 
Apis cerana indica Fab. workers in a field of desi cotton. (Gossypium arboreum Linn.). Am. Bee J. $119(2): 106$.

Tewari, G.N. and Singh, K. 1983. Studies on insect pollinators in relation to seed production in cauliflower (Brasicica oleracea var. botrytis L.). Indian Bee J. 45(2/3) : 54-55.

Verma, S.K. and Joshi, N.K. 1983. Studies on role of honeybees in the pollination of cauliflower (Brassica oleracea var. botrytis). Indian Bee J. 45(2/3) : 52-53.

Wakhle, D.M., Nair, K.S. and Phadke, R.P. 1978. Effect of bee pollination on the oil and protein content in the seeds of sunflower (Helianthus annus L.). Indian Bee J. 40(1) : 1-2. 


\section{PESTICIDAL POISONING TO HONEYBEES}

TrOPICAL and subtropical climate of India presents suitable conditions for the outbreak and appearance of many pest problems. The pest problems have been further aggravated by the advancement in agricultural technology. Irrigated crops, intensive agriculture, introduction of crops and crop varieties and disturbing the indigenous and primitive cropping patterns have contributed in increasing the pest problem of crops. Reduction in uncultivated land, corners and bunds destroy nesting and hibernating places of wild pollinators and succession of nectar and pollen yielding flowers round the year is destroyed. Weedicides are used to control the weeds, and hence lead to starvation of pollinating insects. The advanced agricultural technology has helped to destroy the agriculture cycle through indirect effect. The re is also a prominent negative direct factor, i.e., the insect pollinators are killed by pesticidal usage in crop protection. There is increasing use of pesticides for the control of rodents, mites, insects, nematodes and fungal and bacterial diseases of crop plants. The loss by bee kill is direct, i.e., loss of honey production and indirect inadequate pollination of crops resulting in reduced productivity.

Entomologists have been loudly talking about pest management or integrated pest management. Virtually speaking there is hardly any form of integrated pest management in India and blanket pesticidal applications are given. Most farmers apply large quantities of pesticides at regular intervals and in most cases the pesticides are non-selective coupled with untimely application. Unfortunately honeybees are susceptible to many pesticides used in pest control programmes. This problem is recently overshadowing all other problems in apiculture. Farmers in India have small holdings and hand sprayers/ dusters are commonly used for treating small area each day. This results into a continuous threat of chemical poisoning to bees. Moreover, there is no coordination between the beekeepers and the farmers by any Government decree and, therefore, measures to save bees cannot be taken.

Large number of killed bees are found in front of the hives (Fig.78) or in the fields by insecticidal poisoning. It is not possible to quantify the loss in terms of food production or to assess the financial value of the bees killed. Even more important is the loss in future crop yields because a beekeeper whose bees are killed gives up beekeeping and others too are discouraged to take up beekeeping. Therefore, a balance sbeet between the gains in crop yields by control of pests and losses due to decreased pollinator activity and honey production by bee kill should be worked out. While controlling pests the scientists and farmers are looking on to one aspect of the economic considerations in insecticidal applications. Our primary aim should be to assess how crop pests can be kept under control without killing insect 


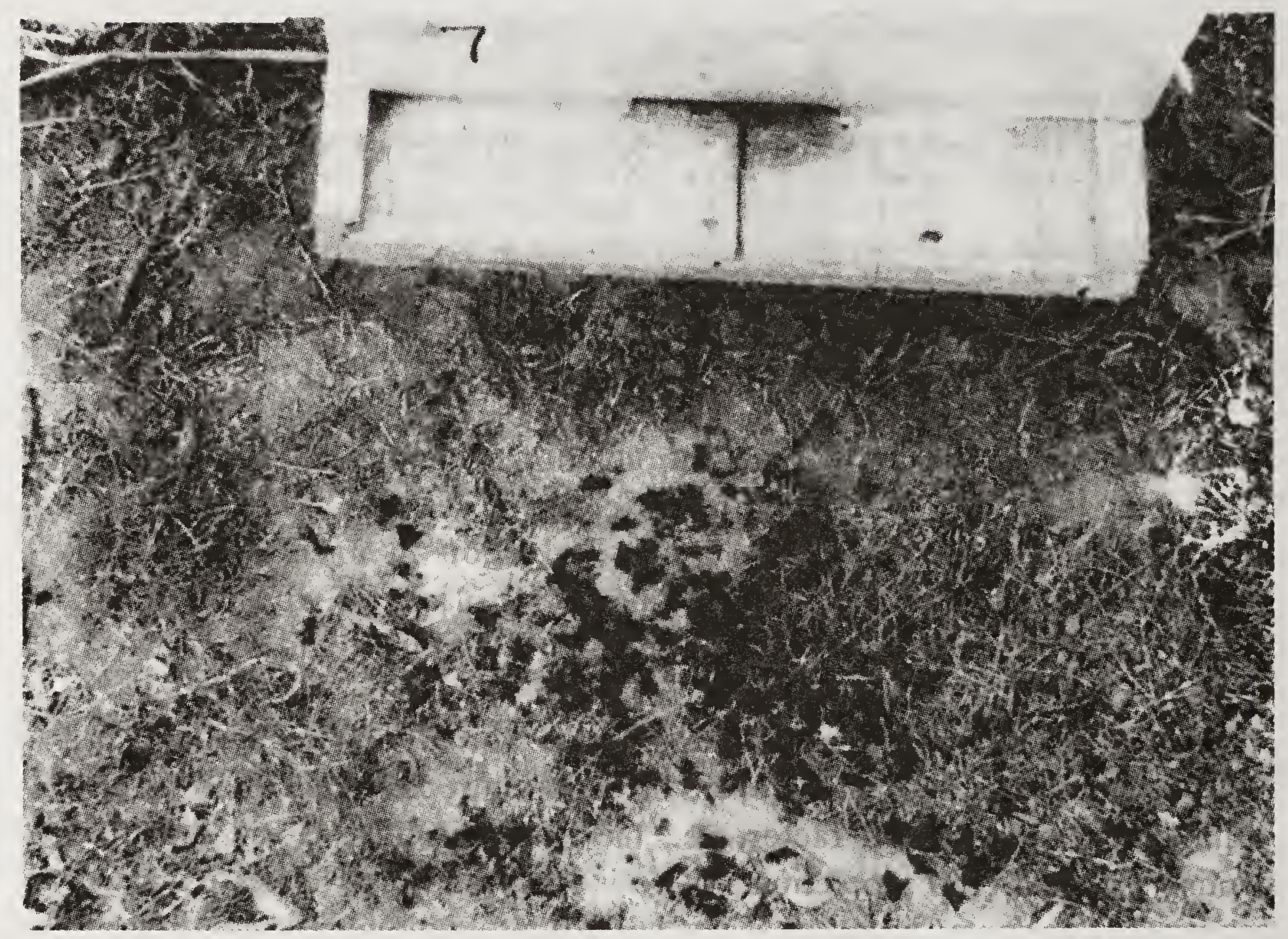

Fig. 78. Pesticidal poisioning of bees. Large number of dead bees in front of hive entrance.

pollinators and to ensure optimum pollination by these insects. Widespread destruction of beneficial insects (including pollinators) often occurs as a consequence of irresponsible and improper use of pesticides. It should be accepted that some loss is inevitable in certain circumstances and that a realistic aim should be an acceptably low level of loss rather than complete protection of bees. In short the following constraints are important:

(i) Use of inapropriate pesticides, ill timed, wrong methods of application, wrong formulations and unnecessary high doses;

(ii) over reliance on chemical methods of pest control; and

(iii) absence of certain essential instructions and legislation for using pesticides.

\section{How are bees exposed to pesticidal hazards}

Many of the Indian crop plants need cross-pollination and about one-third of the cropped area is under entomophilous crops. These crops are infested by pests even during flowering and their depredations warrant the application of control measures. The pesticidal control of the pests of crops which also serve as bee forage pose serious danger and eliminates large population of insect pollinators. Some points on the use of insecticides for pest control visa-vis insect pollination in some of the important crops are highlighted here.

Cotton. It is most dangerous crop for bees. As many as 15-20 insecticidal applications at shorter and regular intervals a re recommonded for the control of various cotton pests. The flowering continues for about 2 months and during this period insecticides are regularly applied for the control of many 
pests like bollworms, aphids, bugs, etc. Foraging bees a re killed by these sprays. New generation of bees develop in 3 weeks. Insecticidal applications at shorter intervals than this, kill more adult bees than can be replaced and ultimately the colonies die. But co-ordinated application of insecticides can minimize bee kill. (1) Flowering in cotton continues for about 2 months but flowers that set fruit appear within 3-4 weeks. Therefore, use of insecticides during this period should be reduced so that bees can be moved to the crop. (2) Nectar in flowers and extra floral nectaries is exhausted by mid day and very few bees are foraging in the afternoon when insecticides can be applied with reduced hazards to bees. (3) Air spraying has picked up for cotton. In such a situation the colonies should be located away from the flight path of the plane.

Brassica and vegetable seed crops. These are attacked by aphids, caterpillars and bugs during flowering and pod formation stage. These crops include oilseeds Brassica, seed crops of cauliflower, cabbage, radish, turnip, carrot, fennel and coriander. In these crops too the flowering is greatly extended, lasting for about $1-1 \frac{1}{2}$ months. These crops need insecticidal applications during flowering periods. But all these crops a re also enthusiastically foraged by bees which are very useful pollinators of these crops. There is extensive pesticidal poisoning to bees on these crops. There a re no specific recommendations to sa feguard bees and only general guidelines to reduce bee kill can be followed, though Singh (1969) sprayed Endosulphan on mustard to control aphids at $0800,0900,1630$ or 1730 hrs and found that Apis spp. foraged between 1030 and $1530 \mathrm{hr}$ without any effect on foraging intensity, and no bees were killed.

Sunflower. Its cultivation is gaining importance in India. Bees contribute much in increased crop production by pollination services but bee losses have been reported by insecticidal sprays for the control of aphids and caterpillars. In India Endosulphan was found to be less toxic to honeybees than Fenthion, Carbaryl or Parathion and seed set and yield were not affected since bee activity was not reduced in Endosulphan sprayed plots (Ramakrishna et al., 1974; Bhattacharya et al., 1982). Bees mostly forage in the forenoon and there is limited activity till early afternoon. Therefore, evening or late in the afternoon is appropriate time for chemical control operations.

Sesame. It is automatic self-pollinated but natural cross-pollination also occurs. Honeybees are very active on the flowers of sesame. The crop at flowering stage suffers from the attack of aphids, brown leafhopper, sucking bugs, whiteflies and caterpillars. Chemical application at blossoming would cause hazards to bees also.

Seed crops. Like lucern and clovers these are rich bee forages. Under semi-arid tropics the legume flowers usually close in the afternoon and it allows time for safe application of pesticides afterwards against caterpillar pests.

Pulses. Like soybean, cajanus and others are self-pollinated crops but yield increases by bee pollination bave been observed. Considerable mortality 
of honeybees from insecticide poisoning is reported in some countries but lack of knowledge in India is due to non-monitoring of hazards.

Cucurbits. These require the control of fruit flies, pumpkin beetle and aphids when in flowering. Cover sprays of insecticides are given against these pests. Honeybees visit the flowers of melon and other cucurbits. Steps to minimize bee kill from these sprays are required.

Tobacco. In this case self-pollination is normal but honeybees and other insects visit the flowers for nectar, effecting some cross pollination. Aphids, whiteflies, thrips and caterpillars are the pests which may warrant insecticidal application during flowering which consequently would lead to bee hazards. Flowering period in coffee is short and insecticidal applications can be avoided during coffee flowering. Coffee may be attacked by bugs, leaf miner and thrips during flowering. In case of outbreak during flowering, the crop should be treated when bees are not active and less persistent insecticides be used.

Pome and stone fruits. Apple, peach, plum, apricot and almond are attacked by caterpillars at blooming time. Insecticidal use has been suggested by economic entomologists against blossom thrips, though economic losses by thrips have not been ascertained. The recommendations are made in ignorance of insecticidal bee hazards. Therefore, caution is important so that the huge benefits from bee pollination are not reduced.

Other fruit crops. Insecticides can be applied for pest control at flowering time in citrus, litchi, olive, grapes, coconut and cocoa. Care should be taken because they are also visited by bees for floral rewards.

\section{Symptoms and effects of pesticidal poisoning}

Bees come in contact with pesticidal deposits while foraging on treated crops or weeds where the chemicals are deposited by drifting. The nectar and pollen can also be contaminated with pesticides and there can be stomach toxicity to bees and also to brood when fed on contaminated pollen. Some pesticides may even cause hazards by fumigant action. After gaining entry into body, different pesticides have different modes of action. Atkins (1982) has given the detail of specific symptoms caused by poisoning of different groups of pesticides but general symtoms of pesticide poisoning are:

1. Appearance of large number of dead bees in front of the hive. Bees also die in the field and in between the field and the hive.

2. Bees become paralytic, lose the power of orientation; legs, wings and degestive tract stop functioning and poisoned bees show unco-ordinated movements.

3. Abdomen becomes distended.

4. Bees are irritated and become aggressive; they sting heavily and guard bees a re confused.

5. Regurgitation of gut contents can occur.

6. Brood chilling can occur due to reduced adult bee population.

7. Contaminated pollen can be collected by bees and stored as bee bread. This pollen fed to brood results into dead brood inside the colonies; young emerging bees are also killed. 
8. Sometimes the queen is also affected. Queen may stop laying eggs or lays eggs in irregular pattern, there may be brood in only some of the: cells of the brood area, as in case of colonies suffering from foul brood disease. In colonies which survive, queen may be superseded. Sometimes queenlessness may develop.

9. Longevity of adult bees is reduced due to sub-letbal doses of pesticides.

\section{Pesticides and their relative toxicity to bees}

Some remarkable studies have been conducted on relative toxicity of pesticides to Apis mellifera and Atkins et al. (1973) bave categorized the pesticides on the basis of their relative toxicity. Exhaustive reviews and summary of the results of their laboratory and field studies with large number of pesticides are very illuminating and serve as an important reference. As per their categorization the pestiçides in use in India are listed in tables ahead. The list is very important in choosing the appropriate pesticide, particularly when alternate choices for a pest control are available.

Some insecticides bave been screened in laboratory in India for their toxicity. to bees. First study in this field was carried out by Cherian and Mahadevan (1946) with DDT and Gammexane against Apis cerana indica. Hameed et al. (1973) allowed the worker bees of Apis mellifera to forage on cut flowers of mustard to which systemic and contact insecticides had been sprayed. On the basis of safety index Formothion, Vamidothion, Dimethoate and Phosalone were considered to be relatively safer to bees. Contact toxicity to Apis cerana of insecticide applied as sprays was compared with Menazon by Kapil and Lamba (1974). Taking the $\mathrm{LC}_{50}$ for Menazon as 100, the comparative yalues for Endosulphan, Eormothion, Methyl demeton, Endrin, Dieldrin, Malathion, Parathion, Phosphamidon, Lindane, Phorate and Mevinphos were 1.17, 1.18, 14.00, 15.70, 17.79, 22.25. 26.01, 28.45, 36.99, 57.96 and 64.24 respectively. Singh et al. (1974) tested 15 insecticides and reported that Menazon and Endosulphan were least toxic and were considered nontoxic to Apis cerana at their recommended doses. According to Thakur et al. (1981), Fenitrothion -and Fenthion were highly toxic: as compared to Endosulphan and Trichlorfon and Hinosan were moderately toxic as determined by residue film method. Comparative toxicity of organophosphates, chlorinated hydrocarbons and carbamates was worked out by Bai and Reddy (1977b). Attri and Sharma (1969) and Mishra and Verma (1982) also assessed the contact and oral toxicities of some insecticides. Toxicity of several organophosphates to Apis cerana was determined in the laboratory using topical application method (Qadiri et al., 1982). Determination of the kirretic: parameters of the reactions by the authors showed that differences in anticholinestrase activity were due mainly to differences in affinity rather than to different chemical structure of the compounds.

Cholinestrase inhibition by insecticides. in Indian honeybee was studied by Dale and Mehrotra (1976). Bai and Reddy (1977a) reported that signs of poisoning in Apis cerana indica were first observable when acetylcholinestrase inhibition exceeded $35 \%$ and death occurred at $96 \%$ or more inhibition. 
Reddy (1979b) reported the inhibition of magnesium activated adenosine triphosphate as the criterion to determine the degree of organochlorine insecticide poisoning to Apis cerana indica. Digestive amylase and protease of Apis cerana indica were inhibited to the same level by the insecticide poisoning from different groups of insecticides (Reddy, 1979a). Studies on the level of ions of amino acids in the haemolymph of worker bees of Apis cerana indica treated topically showed pronounced stimulatory effect with organophosphates, a relatively strong inhibitory action with chlorinated hydrocarbons and an intermediary effect with carbamate pesticides (Reddy; 1983).

\section{PESTICIDES MOST TOXIC TO BEES}

For minimal hazard to honeybees, these pesticides should not be applied on blooming crops or weeds. Their residual toxicity is usually high even after $10 \mathrm{hrs}$.

\begin{tabular}{ll}
\hline Acephate & Formothion \\
Aldicarb G & Gamma BHC \\
Aldrin & Heptachlor \\
Aminocarb ( $\mathrm{kg} / \mathrm{ha}$ or more) & Isobenzene \\
Azinphos-ethyl & Lead arsenate \\
Azinphos-methyl & Malathion D \\
Bendiocarb & Malathion ULV (0.5kg/ha or more) \\
Calcium arsenate & Methamidophos \\
Carbaryl ULV (over $0.5 \mathrm{~kg} / \mathrm{ha}$ ). & Methidathion \\
Carbaryl D, WP; XLR & Methiocarb \\
Carbofuran F & Methomyl D \\
Carbophenthion D & Mevinphos \\
Carbosulfan & Monocrotophos \\
Chlorpyrifos & Parathion \\
Cypermethrin (over $0.025 \mathrm{~kg} / \mathrm{ha})$ & Parathion-methyl: \\
Deltamethrin & Permethrin \\
Diazinon, & Phenthoate \\
Dicapthon & Phosmet \\
Dichlorvos & Phosphamidon \\
Dicrotophos & Phoxim \\
Dieldrin : & Pirimiphos-ethyl \\
Dimethoate & Pirimiphos-methyl: \\
Dinoseb & Propoxur \\
DNOC (more than $0.4 \%$ dilution) & Quinalphos \\
EPN & Resmethrin \\
Fenitrothion & Tetrachlorvinphos (at higher rates) \\
Fensulfothion & Thionazin \\
Fenthion & Triazophos \\
Fenvalerate & Vamidothion \\
Flucythrinate & \\
\hline & \\
\hline
\end{tabular}

\section{PESTICIDES VERY TOXIC TO BEES}

For minimal hazard to honeybees, these pesticides should be applied only during late evening. Their residual toxicity is usually low within 8 hrs: 
Chlorfensulphide

Chlorobenzilate

Chloropropylate

Cryolite

Cyhexatin

Dicofol

Dinchlor

Diflubenzuron

Dinocap

Disulfoton G

Fensulfothion G.

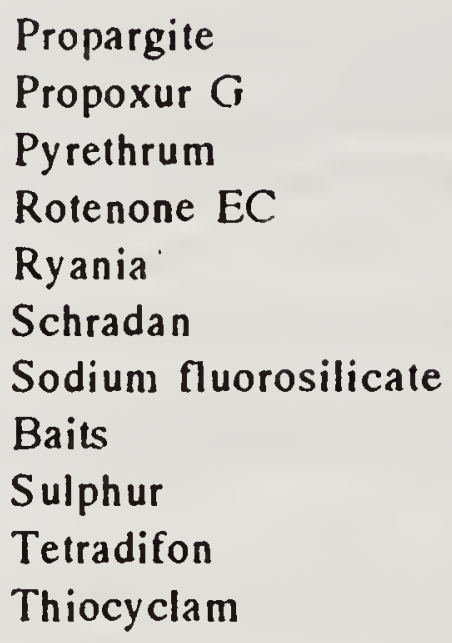

Losses of bees due to field application of pesticides serve as valuable information but such studies and assessments are difficult to be made. Only limited surveys of extent of honeybee losses have been conducted in Western countries. Some useful information can be found in the review of Anderson and Atkins (1968). Laboratory studies have been interpreted to obtain useful information to predict the expected hazards of pesticides to honeybees in field application (Atkins et al., 1973). $\mathrm{LD}_{50}$ values with slope (probites) and field test data on residues to bees can be used to predict the degree of toxicity or hazards to honeybees in the field when pesticide is applied as an early morning spray. In most instances the $\mathrm{LD}_{50}$ ( $\mu \mathrm{g} / \mathrm{bee}$ ) can be converted into equivalent number of $\mathrm{kg}$ of chemicals per ba when applied to aerial portion of plants. Generally speaking, a pesticide with a slope value of 4 probits or higher can be made safer to honeybees by only slightly lowering dosage. On the other hand, by increasing the dosage only slightly the pesticide becomes much more hazardous. This valuable information can be used to manipulate the field hazards to bees. Honeybee mortality predictor has been developed by Atkins et al. (1981) with laboratory data on bee toxicity.

\section{Reduce pesticidal poisoning to bees}

Crane and Walker (1983) have given the following quick guide to minimize bee kill.

Is the pest infestation heavy enough to make treatment worth while?

Yes, choose the pesticide carefully. Read the label in detail.

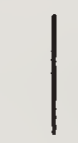

Are any plants in bloom in/around the crop to be treated?

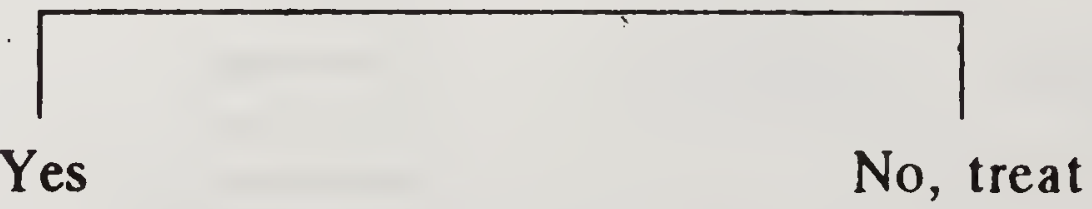

Are bees foraging in/a round

the crop to be treated?

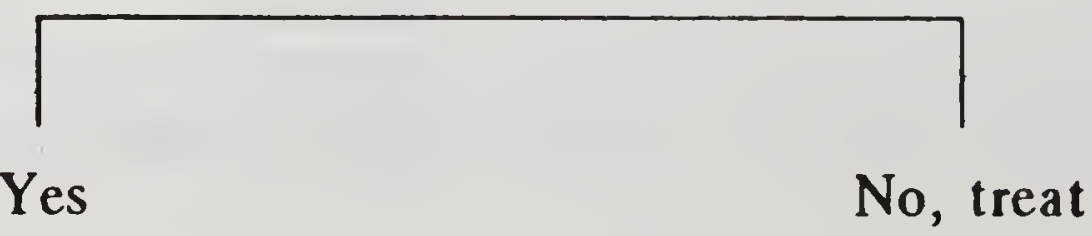


Can bees be moved

prior to treatment?

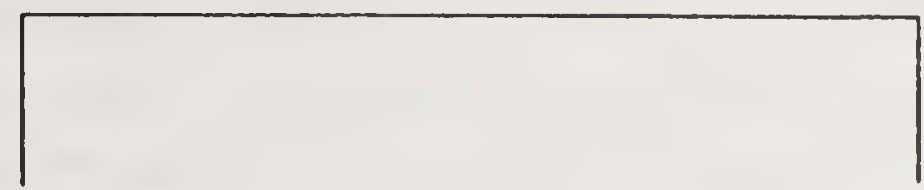

Yès, move bees and treat

No, use non-persistent insecticide, apply wisen bees are not foraging.

Most of the pesticides/insecticides in use for the control of insect pests a re also hazardous to bees but most pesticides used for the control of bee diseases and non-insect pests are not hazardous. This subjects the bees to extensive hazards of chemical poisoning. But certain points can be kept in mind for reducing these hazards. A golden rule for the safety of bees and other insect pollinators is not to apply pesticides unless the crop is so heavily infested that treatment is worthwhile. Gain from the control of pest should out weigh the losses to beekeepers and lossess due to insufficient pollination. Application of pesticide should be avoided when the crop is in bloom. In most cases it can be possible to control the pest before the start of flowering and next treatment can be postponed till the end of flowering period but in some crops the flowering period is staggered and pesticidal treatments may become essential.

Location of bees. Bee colonies. should not be located in and around the field where insecticides are to be applied. It is always possible to move bees to safer location. Chemical treatments in the vicinity of apiary are also equally dangerous. The farmers can also help reducing bee kills but in India there is no such co-ordination. In many countries there is legislation safeguarding bees, though enough safeguard may not be achieved.

Pesticide formulation. Dust formulations are more bazardous to bees than sprays, as these contaminate atmosphere and can be carried to neighbouring loaclities/fields. Wettable and dispersable powders have longer residual effect than emulsions. Bees are less likely to come in contact with emulsions because these are absorbed in surface tissues or for systemic translocation. Moreover small droplet sprays are safer than coarse droplet sprays. Granular formulations applied in soils are the safest for bees but micro-encapsulated granules applied to crops can be collected by bees as they are within the size range of the pollen grains. These encapsulated granules are stored in the hive, where they may be eaten by adult bees and fed to brood for many instances of high bee mortality and long-term contamination of hive and hive products. Oil emulsions are more dangerous to bees and should be avoided.

Selection of pesticides. In general organic pesticides are less toxic to bees than inorganic ones. Organic insecticides also have shorter residues. For the control of any pest the economic entomologists and farmers have alternate choices. Therefore, pesticide chosen for application should be comparatively safer to bees with shorter residual life.

Timing and method of application. It is most dangerous to apply 
insecticides when the bees are actively foraging. They come in direct contact with insecticidal applications. Flower rewards a re presented by a crop during specific day hours. In most cases the insecticidal applications can be given beyond these day hours and when the bee activity is least. It is also possible to treat crops before or after bee activity. For example bees in winter start foraging late by about $1000 \mathrm{hr}$ and stop foraging before $1600 \mathrm{hr}$. By treating Brassica and other winter vegetable seed crops before the bee activity starts or after the bees stop working can be a useful practice to reduce bee hazards. Ground applications are more hazardous when small areas a re treated everyday. Aircraft sprays, when the bees are foraging, hit larger number of foraging bees than by ground spray applications.

Dosage of pesticide. Sometimes pesticides per unit a rea a re recommended for pest controligiving lowest and highest ranges of quantity. But this makes a lot of difference in bees hazards. The recommendations for pest control should be specific; quantity and dosage should be lowest that gives good pest control. Slight change in dosage cause greater difference in teekills in the field.

Local beekeepers should be warned before applying pesticides. The bee colonies can be moved to other localities or bees can be kept confined inside the hive during treatments. While confining bees, due attention should be paid to some important points. While confining the bees, proper space should be available. Congestion and overcrowding can lead to bee mortality. Ventilation must be provided at the top and/or sides of the hive and not only through the entrance because this may be blocked by dead bees. Ventilating screen should have as large a mesh as possible. Bee hives in which the bees are confined should be provided with shade. Shade can usually be provided by the use of local material. Covering the hives with wet clothes/gunny bags can be of great benefit because evaporation of the water helps to reduce the rise in colony temperature. If peśticides are applied by aircraft, it is important to cover whole of the hive; otherwise it may be sufficient to drape a wet cloth on the flight entrance. This greatly reduces flight activity of bees but it does not prevent flight entirely. During warmer months, it becomes essential: to provide water inside the hives. This water is taken by the bees and spread out in the hive, where it evaporates and thus reduces the high temperature. The confinement must of course continue as long as the pesticide near the hive retains unexpectable toxicity and its duration can satisfactorily be reduced, only if the pesticides applied do not have long residual life. In case there a re no stores in the hive then pollen supplement/substitute, sugar syrup may also be provided.

When the damage to bees and also to brood is due to pesticidal contaminated pollen being carried back to the hive, two actions by the beekeepers may be helpful, i.e:, prevention of pollen being stored in the hive and provision of a safe pollen supply inside the hive. Provision of pollen cakes in the hive during this period greatly, reduces the collection of toxic pollen. Cakes of pure pollen are more effective than pollen supplement or pollen substitutes. 
Bee repellents. Safety of the pollinators against pesticides can be ensured by providing them a functional protection through the use of repellents. Basic idea of using repellents is to mix such chemicals with poisonous pesticides which would repel bees for sometime and reduce bee losses. Pesticidal treatment and residues remain bazardous to bees for few hours and keeping bees away during this period is helpful. More chemicals bave been screened by Atkins et al. (1975). Pyrethroids have been found to give some repellency. Oily materials increase the absorption of pesticides and less bazardous residues are left by such adjuvants. Plastic and latex-rasin additives make insecticidal sprays safer for bees.

Some work has also been done in India. Lantana oil (from leaves) was shown to have repellent activity against honeybees (Apis mellifera) by Attri and Singh (1977). Gupta and Kapil (1983) tested the response of workers of Apis florea to 16 compounds (14 ketones +2 essential oils), in semi-field conditions each with a concentration of $5 \mathrm{~g} /$ litre. Maximum repellency was obtained with 0 -amino acetophenon and ethyl benzyl netone, while minimum was with Mentha piperata oil. Gupta and Mohla (1986) also found a structureactivity relationship of straight chain ketones and an increase in repellency with an increase in the number of carbon atoms was a general trend. Gupta (1986) also reported that linalol, terpineol and $D(+)$ carvone could show a repellent effect for a maximum of $2 \mathrm{hr}$. Kumar et al. (1986) studied the oils of Citronella, Lantana, Eucalyptus, Chenopodium and Trachyspermum for their gustatory repellency and toxicity and found that Citronella oil was inost repellent with least toxicity to $A$. cerana indica. Ketones a re good repellents but their cost is prohibitive for field use. Effective and economical repellents are needed to be searched to fulfil the noble aim of saving bees.

\section{Care of the poisoned colonies}

Colony loses foragers by poisoning. The income of pollen and nectar is adversely affected in the hive. In such cases pollen and sugar syrup should be supplied. If the treatment remains residual for long time then the bee colonies should be moved to safer places. Sometimes poisoned pollen is stored in combs and this causes adult bee and brood death even after the treatments are over. This badly affects the development of bee colonies. In such cases the combs with poisoned pollen can be soaked in water for few hours and washed by slight shaking. The strength of poisoned colonies is reduced and uniting of weak colonies should be preferred. Half to one kilogram of bees can be added to the weak colonies for quick recovery.

\section{Plant poisoning to bees}

There are evidences of pollen or nectar of some plants being poisonous to bees. Poisonous substances in nectar or pollen bave been identified in few cases. Plant poisoning is difficult to differentiate from pesticidal poisoning. Field bees may die in front of hive entrance. Some plant poisoning render field bees black and shiny from loss of hair. Brood can also be killed and dead brood do not have browll or black colour as produced in foul brood 
diseases. Larvae in all stages may die. Egg laying by queens can be affected and queens can be superseded. Following plants have been found to be poisonous to bees:

\author{
Buckeye \\ Black night shade \\ Death camas \\ Dodder \\ Leather wood \\ Locoweeds \\ Mountain laurel \\ Seaside arrowgrass \\ Whorled milkweed \\ Western false hellebore \\ Rhododend rons
}

$\begin{array}{ll}\text { - } & \text { Aesculus californica } \\ \text { - } & \text { Solanum nigrum } \\ \text { - } & \text { Zygadenus venenosus } \\ \text { - } & \text { Cuscuta spp. } \\ \text { - } & \text { Cyrilla racemiflora } \\ \text { - } & \text { Astragalus spp. } \\ \text { - } & \text { Kalmia latifolia } \\ \text { - } & \text { Triglochin meritima } \\ \text { - } & \text { Asclepias subverticillata } \\ \text { - } & \text { Veratrum californicum } \\ \text { - } & \text { Rhododendron spp. }\end{array}$

Cases of poisonous pollen have been reported in India. Curved abdomens, outstretched wings with loss of wing power, inability to hold on with the legs of bees foraging in Euphorbia geniculata were observed by Deodikar et al. (1958). Chaubal and Deodikar (1963) also reported the presence of pollen grains of poisonous nature in honey sample from Western Ghats. The plants were : Clematis gouriana, C. wightiana, Datura arborea, Euphorbia geniculata, Lasiosiphon eriocephalus and Lobelia nicotianaefolia. Nectar of tea, Camellia thea, was found toxic to honeybees and colony gathering nectar of this plant suffered larval mortality (Sharma et al., 1986).

\section{REFERENCES}

Anderson, L.D. and Atkins, E.L. 1968. Pesticide usage in relation to beekeeping. Ann. Rev. Ent. 13 : 213-38.

Atkins, E.L. 1982. Injury to honey bees by poisoning. In The Hive and the Honeybee. Dadant and Sons Inc., U.S.A. pp. 663-96.

Atkins, E.L., Greywood, E.A. and Macdonald, R.L. 1973. Toxicity of pesticides and other agricultural chenicals to honeybees: Univ. Calif. Div. Agri. Sci. Leaf. 2287.

Atkins, E.L., Macdonald, T.P., McGovern, M. Beroza and Greywood-Hale, E.A. 1975. Repellent additives to reduce pesticide hazards to honeybees: Laboratory tests. J. apic. Res. 14(2):8597.

Atkins, E.L., Kellum, D and Atkins, K.W. 1981. Reducing pesticide hazards to honeybees; Mortality production techniques and integrated management strategies. Division of Agricultural Sciences, Univ. of Calif. Leaflet No. 2883. pp.22.

Attri, B.S. and Sharma, P.L. 1969. Toxicity of some new insecticides to the Indian honeybee, Apis indica. Pesticides 3(6): 27-29.

Attri, B.S. and Singh, R.P. 1977. A note on the biological activity of the oil of Lantana camara L. Indian J. Ent. 39(4) : 384-85.

Bai, A.R.K. and Reddy, C.C. 1977a. In hibition of acetylcholinestrase as a criterion to determine the degree of insecticide poisoning in Apis cerana indica. J. apic. Res. 16(2) : 112-14.

Bai, A.R.K. and Reddy, C.C. 1977 b. Laboratory toxicity of some insecticides to Apis cerana indica. J. apic. Res. 16(3): 161-62.

Bhattacharya, P., Samul, R.C., Ghosh, M.R., Dasgupta, S.K. and Roy, A. 1982. Sunflower seed yield as influenced by pollination and insect pests. Proc. 10th Int. Sunflower Conf. Sulfers Paradise, pp. 132-34. 
Chaubal. P.D. and Deodikar, G.B. 1963. Pollen grains of poisonous plants. 1. Poisonous pollen in honey samples from Western Ghats (India). Grana Polynol. 4(3) : 393-97.

Cherian. M.C. and Mahadevan, V. 1946. Preliminary trials with DDT and Gammexane against the Indian bee. Apis indica. Indian Bee J. 8(9/10): 128-30.

Crane. Eva and Walker, P. 1983. The impact of pest nianagement on bees and pollination. Trop. Dev. and Res. Int., U.K. pp. 129-73.

Dale, D. 1975. Studies on the inhibition of cholinestrase from Indian honeybee, Apis indica. Pesticide $9(2): 25$.

Dale, D. and Mehrotra, K.N. 1976. Studies on the inhibition of honeybee cholinestrase by carbamates. Entomon 1(1) : 39-42.

Deodikar, G.B., Thakar, C.V., Shah, P.N., Salvi, S.R. and Chitale, P.S. 1958. Foraging of honeybees on fungal rust spores (Cystospora oleae) on Olea dioica. Bee WId 39(5) : 120-21.

Gupta, M. 1986. Conditioning of Apis florea F. as a function of duration of exposure to chemical vapours at Rc 50 and Rc 60 dilutions. Beitr. Ent. 36(2) : 225-29.

Ciupta, M. and Kapil, R.P. 1983. Olfactory response of Apis florea F. to some repellents in semi-field conditions. Proc. 5th Int. Symp. Polln., Versailles, pp. 65-78.

Gupta, M. and Mohla, R.S. 1986. Aliphatic straight chain ketones as potential bee repellents. Chem. and Ind. 5 : 327-28.

Hameed, S.F., Adlakha, R.L. and Gianzo, S.P. 1973. Relative toxicity of some insecticides to the workers of Apis mellifera. Madras agric. J. 60(7): 552-56.

Kapil. R.P. and Lamba, D.P.S. 1974. Toxicity of some important insecticides to Apis cerana Fab. Indian J. Ent. 36(1): 6-10

Kumar, J.. Patial, S.K. and Mishra, R.C. 1986. Evaluation of some essential oils as repellents to Indian honeybee, Apis cerana indica F.I. Gustatory repellency and toxicity. J. apic. Res. 25(4) : 256-59.

Mishra, R.C.. and Verma, A.K. 1982. Relative toxicity of some insecticides to $A$ : cerana indica workers. Indian Bee J. 44(3) : 69-71.

Qadri, S.S.H., Sultana, H. and Anjun, F. 1982. Selective toxicity of organophosphorus and carbanate pesticides to honeybees and freshwater fish. Int. Pest Cont. 24(5) : 124-26.

Ramakrishna, C.. Rajmohan, N. and Subramanian, T.R. 1974. Effect of insecticidal sprays on the pollinators of sunflower. Madras agric. J. 61(6): $175-77$.

Reddy, C.C. 1979a. Effect of insecticides on the activities of digestive amylase and protease of honey bee, Apis cerana indica. Indian Bee J. 41(3/4) : 19-23.

Reddy, C.C. 1979b. Inhibition of magnesium activated adenosine triphophate as the criterion to determine the degree of organochlorine insecticide poisoning of honeybees, Apis cerana indica. Indian Bee J. 41(3/4) : 19-23.

Reddy, $C . C .1983$. Effects of pesticides on the level of ions and amino acids in the haemolymph of worker Apis cerana indica Fab. Indian Bee J. 45(5) : 105-07.

Sharma, O.P., Raj, D. and Garg, R. 1986. Toxicity of nectar of tea (Camellia thea L.) to honeybees. J. apic. Res. 25(2): 106-08.

Singh, J.P. 1969. Effect of Thiodan on honeybees (Apis indica Fab.). Indian Bee J. 30(1) : 9-10.

Singh, M.T., Sharma, P.L. and Dhaliwal, H.S. 1974. Toxicity of insecticides to honeybee workers, Apis cerana indica. Pesticides 8(12) : 28-29.

Thakur, A.K., Kashyap, N.P. and Dogra, G.S. 1981. Relative toxicity of some pesticides against Italian bees, Apis mellifera. Indian Bee J. 43(4) : $101-03$. 


\section{INDEX}

Acarapis dorsalis, 113

A. externus, 113

A. vagans, 113

A. woodi, 112

Acephate, 156

Achroia grisella, 114

Actinodephnae hookeri, 124

Ageratum conyzoides, 94

Albizzia sp., 87

Aldicarb, 156

Aldrin, 156

Alfalfa, 91

Allethrin, 157

Allium cepa, 94, 147

Althea rosea, 82, 94

Amegilla, 8

American foul brood, 108

Aminocarb, 156, 157

Amitraj, 157

Ammobates, 8

Anacardium occidentale, 88, 146

Ananas sativus, 146

Andrena, 8

Anomala dimidiata, 120

Anthidiellum, 8

Anthidium, 8

Anthocopa, 8

Anthophora, 8

Antigonon leptopus, 94

Apis, 8

A. adreniformis, 18

A. cerana indica, 3, 4, 9, 10, 11, $12,13,14,25$, $27,28,32,62,65,70,100,107,109,113$, $116,120,145,148$

A. dorsata, $3,9,10,18,57,82,114,145,148$

A. florea, 3, 9, 11, 12, 18, 57, 82, 116, 146, 148

A. indica, 13

Apis irridescent virus, 106

A. koschevnikovi, 18

A. Laboriosa, 18

A. mellifera, 3, 4, 5, 9, 10,11, 25, 27, 31, 32, 57 , $62,66,78,90,100,101,107,108,113,114$, $116,120,148$

A.m. adansonii, 17,65

A.m. capensis, 17,65

A.m. carnica, 14,15

A.m. caucascica, 14, 15

A.m. intermissa, 16

A.m. jemenitica, 16

A.m. lamarckii, 16

A.m. ligustica, 14, 15

A.m. littorea, 16

A.m. major, 16
A.m. mellifera, 14,15

A.m. monticola, 17

A.m. nubica, 16

A.m. remipes, 15

A.m. sahariensis, 16

A.m. scutellata, 16

A.m. syriaca, 15

A.m. unicolour, 17

A. spp., 3

Ascophera apis, 112

Aspergillus flavus, 112

Aster thomsoni, 94

Azinphos- ethyl, 156

Azinphos- methyl, 156

Azocyclothing, 157

Bacillus thuringiensis, 117, 157

Bacterial diseases, 108

Banana, 88

Bee brush, 41

Bee escape, 43

Bee-hive products, 122

Bee venom, 134

Honey, 122

Royal jelly, 136

Use of honey, 132

Wax, 133

Beekeeping equipments, 31

Equipment for handling bees, 40

Other beekeeping equipments, 38

Swarm-catching equipment, 41

Bee pasturage, 80

Bee flora of India, 84

Cultivated and wild bushes, shrubs and field crops, 89

Factors affecting nectar secretion, 83

Fruits, 88

Nectar composition, 82

Nectar sugar concentration 80

Omamentals, 94

Vegetables, 93

Bees and their economic importance, 7

Species of honeybees, 9

Wild bees, 7

Bee veil, 40

Bendiocarb, 156

Berberis, 81

Birds and other enemies, 118

Black ants, 118

Bombus sp., 7, 8, 147

bottle brush, 87

Bramble, 89

Brassica, 82, 91 
B. campestris var. toria, 81,147

B. juncea, 81,147

B. oleracea, 146

Braunisapis, 8

Bromprophylate, 157

Calcium arsenate, 156

Californian yellow strain, 4

Camponotus compressus, 118

Callistemon lanceolatus, 87

Capsicum sp., 146

Carbaryl U L V, 156, 157

Carbaryl D, 156, 157

Carbofuron, 156, 157

Carbophenthion, 156, 157

Carbosulfan, 156

Carica papaya, 146

Carrot, 93

Carvia callosa , 81, 82

Cashew, 88

Centaurea cyanus, 94

Ceratina, 8

Chalicodama, 8

Chlorbenside, 157

Chlorbenzilate, 158

Chlordane, 157

Chlordineform, 157

Chlorfenethol, 157

Chlorfenson, 157

Chlorfensulphide, 158

Chlorfenvinphos, 157

Chlorprophylate, 158

Chlorpyrifos, 156, 157

Chlorpyrifos U L V, 157

Cidrella cerata, 81

Cinnamomum incus, 10

Citrus, 88, 89, 145

C. limettoides, 145

Coconut, 89

Cocos nucifera, 89

Coelioxys, 8

Coffea arabica, 91

C. robusta, 91

Coffee, 91

Colletus, 8

Comb foundation, 38

Coriandrum sativum, 93, 146

Cosmos sulphureus, 94

Cotton, 91

Cryolite, 158

Ctenoplectra, 8

Dacus carota, 93, 146

Dalbergia sissoo, 81,86

DDT, 157

Deltamethrin, 156

Demeton, 157

Demeton-S-methyl, 157
Diazinon, 156

Dicapthon, 156

Dichlorfenthion, 157

Dichlorvos, 157

Dicofol, 158

Dicrotophos, 156

Dieldrin, 156, 157

Diflubenzuron, 158

Dimethoate, 156

Dinchlor, 158

Dinobuton, 157

Dinocap, 158

Dioxathion, 157

Discrurus ater, 118

D. macrocercus, 118

Diseases of hees and their enemies, 106

Bacterial diseases, 108

Birds and other enemies, 118

Fungal diseases, 112

Insect enemies of bees, 114

Mites, 112

Protozoan diseases, 111

Viral diseases, 106

Disulfan EC, 157

Disulfoton, 158

DNOC, 156, 157

drum stick, 87

Dummy or division board, 43

Egyptian clover, 91

Ehretia acuminata, 87

Elaphropoda, 8

Endosulfan, 157

Endrin, 157

Enthion, 157

Epeolus, 8

Ephestia cautella, 114

E. kuhniella, 114

EPN, 156

Ethiofencarb, 157

Eucalyptus, 81, 84

Feeders, 41

Fenbutatin oxide, 157

Fenchlorphos, 157

Fenitrothion, 156

Fenoxycarb, 157

Fenson, 157

Fensulfothion, 156, 158

Fenthion, 156

Fenthion G, MA, 157

Fenvalerate, 156, 157

Flucythrinate, 156

Fluvalinate, 157

Foeniculum vulgare, 146

Formetanait, 157

Formothion, 156

Fungal diseases, 112 
Gaillardia sp., 94

Galleria mellonella, 114

Gamma BHC, 156

Gloves, 40

Gossypium sp., 91, 148

Greater wax moth, 115

Grevillea robusta, 81,87

Grewia asiatica, 86

Guizotia abyssinica, 92, 147

Habropoda, 8

Halictus, 8

Hariades, 8

Hibiscus esculentus, 146

Helianthus annuus, 93, 147

Heliothis, 145

Heptachlor, 156, 157

Hevea brasiliensis, 86

Hirad, 84

Hives, types of, 34

Hive tool, 40

Honey extracting equipment, 40

Hydroprene, 157

Impatiens balsamina, 81

Importance and history, 1

Importance, 1

Past and present, 2

Indian bee, 12

Indian labernum, 87

Instinct of reproduction and related management, 60

Control of reproduction, 69

Making colony increase, 69

Laying workers, 64

Reproduction of species, 65

Queen and its management, 60

Isobenzene, 156

Isofenphos, 157

Jamun, 84

Jujube, 89

Karanj, 85

Kashmir bee virus, 107

Lagerstroemia indica, 87

Langstroth ten-frame hive, 34

Lasioglossum, 8

Lead arsenate, 156

Leptophos, 157

Lesser wax moth, 117

Lime sulphur, 157

Litchi, 89

Litchi chinensis, 89, 145

Little bee, 11

Lithurgus, 8

Lonicera sempervirens, 94
Lucerne, 91

Lycopersicon esculentum, 146

Maize, 92

Malathion, 157

Malathion D, 156

Malathion EC, 157

Malathion G, 157

Malathion ULV, 156

Mancozeb, 157

Mangifera indica, 146

Medicago sativa, 57, 91

Megachile, 7

M. flavipes, 148

Melecta, 8

Melipona, 8

Melissococcus pluton, 109

Menazon, 157

Merops orientalis, 118

M. supercilosus, 118

Methamedophos, 156

Methidathion, 156

Methiocarb, 156

Methomyl D, 156, 157

Methoxychlor, 157

Mevinphos, 156

Mimusops elengi, 85

Mirex G, 157

Mites, 112

Monocrotophos, 156

Monomorium destructor, 118

$M$. indicum, 118

Morgania, 8

Moringa oleifera, 87

M. pterigosperma, 82

Morphology, anatomy, colony organization, and life cycle, 20

Anatomy, 23

Morphology, 20

Points of caste distinction, 29

Moulsari, 85

Musa sp., 88

Naled EC, 157

Nephelium litchi, 81

Newton hive, 36

Nicotine sulphate, 157

Niger, 92

Nomada, 8

Nomia, 8

Nomioides, 8, 147

Nosema apis, 111

Nuphilia kuhlii, 120

Oil sprays, 157

Odontomantis micans, 120

Onion, 94

Osmia, 8 
Oxamyl, 157

Oxydemeton-methyl, 157

Parahophites, 8

Parathion, 156

Parathion-methyl, 156

Parevaspis, 8

Permethrin, 156, 157

Pesticidal poisoning to honey bees, 151

Care of the poisoned colonies, 161

Pesticides and their toxicity, 155

Plant poisoning to bees, 161

Reduce pesticidal poisoning, 158

Symptoms and effects of pesticidal poisoning, 154

Petunia alba, 82

Phalsa, 86

Phenthoate, 156

Phorate, 157

Phorate G, 157

Phosalone, 157

Phoxim, 156

Pirimicarb, 157

Pirimiphos-ethyl, 156

Pirimiphos-methyl, 156

Pithitis, 147

P. smaragdula, 148

Plectranthus, 81

P.rugosus, 89

Plodia interpunctela, 115

Plusia, 145

Pollen, 50

Pollination, 138

Extemal agents of pollen transfer, 139

Pollination of crops, 144

Pollination and fertilization, 138

True honeybee, 142

Pome and stone fruits, 89

Pongamia pinnata, 85

Portulaca grandiflora, 94

Predatory wasps, 117

Pride of India, 87

Propargite, 158

Propoxur, 156

Propoxur G, 158

Propoxur MA, 157

Protaetia aurichalcea, 120

P. impavida, 120

Protomelissa, 8

Protozoan diseases, 111

Proxylocopa, 8

Prunus amygdalus, 146

$P$. domestica, 82

P. persica, 82, 145

P. puddum, 89

Psithyrus, 8

Pyrethrum, 158

Pyrus sp., 145
Queen cages, 42

Queen cell protector, 42

Queen excluder, 39

Queen rearing and artificial queen

bee inseminatin, 72

Artificial mating, 75

Biological basis of queen rearing; 72

Insemination, 77

Methods of queen rearing, 73

Selection of mother stock, 72

Quinalphos, 156

Randia demetorum, 124

Resmethrin, 156

Rock bee, 10

Rotenone, 157

Rotenone-EC, 158

Rubber, 86

Rubus ellipticus, 89

$R$. sp., 89

Ryania, 158

Sapindus detergens, 81

S. emerginatus, 87

S. sp., 87

Schefflera wallichiana, 80, 82, 86

Schradan, 158

Seasonal management, 97

Autumn management, 102

Honey extractor, 99

Honey flow period, 98

Monsoon problems, 101

Spring management, 97

Summer routine, 100

Winter hive packing, 104

Winter management, 103

Sesamum indicum, 92

Shisham, 86

Silver oak, 87

Sinapis alba, 147

Smoker, 40

Social behaviour of bees and related management practices, 44

Communication, 54

Division of labour, 44

Food gathering and artificial feeding, 46

Working habits of field bees, 55

Sodium flurosilicate, 158

Solanum melongena, 146

Solidago longifolia, 94

Sphecodes, 8

Starline strain, 4

Streptococcus, 109

Sunflower, 93

Systropha, 8

Syzygium iumini, 84, 124

Tamarind, 87 
Tamarindus indica, 87

Tecoma grandiflora, 81

T. slans, 82

Temephos, 157

TEPP, 157

Terminalia chebula, 84, 124

Teterachlorvinphos, 156, 157

Tetradifon, 158

Tetralonia, 8

Tetraloniella, 8

Thaisac brood virus, 107

Thelepaepale ixiocephala, 81, 82, 87

Thiocyclam, 158

Thionazin, 156

Toon, 87

Toona ciliata, 87

Triazophos, 156

Trifolium alexandrinum, 91, 148

Trigona, 8

Tropilaelaps clareae, 114

Thunbergia grandiflora, 82

Uncapping knife, 40
Vamidothion, 156

Varroa jacobsoni, 113

Vespa, 117

V. auraria, 117

$V$. basalis, 117

$V$. cincta, 117

V. ducalis, 117

$V$. magnifica, 117

V. orientalis, 117

Viral diseases, 106

Vilex negundo, 91

Vitula spp., 115

Wax moths, 114

Wlayati, 87

Woodfordia floribunda, 81, 82, 83

Xylocopa, 8, 147

Zea mays, 92

Zinnia sp., 94

Ziziphus mauritiana, 89, 145 

I SBN $978-81-7164-147-5$

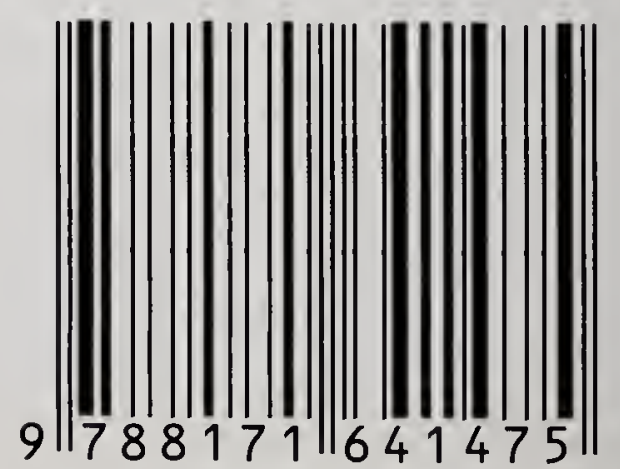

